\author{
Universidade de SÃo PaUlo \\ FFCLRP - DEPARTAMENTO DE FísicA \\ Pós-GraduaÇão em Física Aplicada À Medicina e Biologia
}

\title{
Caracterização e Adaptação do Dosímetro Fricke para Dosimetria em Irradiação de Sangue
}

\author{
Lucas Sacchini Del Lama
}

Tese apresentada à Faculdade de Filosofia, Ciências e Letras de Ribeirão Preto da Universidade de São Paulo, como parte das exigências para a obtenção do título de Doutor em Ciências. Área: Física Aplicada à Medicina e Biologia.

Ribeirão Preto - SP

2013 


\section{LUCAS SACCHINI DEL LAMA}

\section{Caracterização e Adaptação do Dosímetro Fricke para Dosimetria em Irradiação de Sangue}

Tese apresentada à Faculdade de Filosofia, Ciências e Letras de Ribeirão Preto da Universidade de São Paulo, como parte das exigências para a obtenção do título de Doutor em Ciências.

Área de Concentração:

Física Aplicada à Medicina e Biologia.

Orientadora:

Prof. ${ }^{a}$ Dr. ${ }^{a}$ Adelaide de Almeida.

Coorientador:

Prof. Dr. Evamberto Garcia de Góes.

Versão corrigida

Versão original disponível na FFCLRP-USP

Ribeirão Preto - SP

2013 
Autorizo a reprodução e divulgação total ou parcial deste trabalho, por qualquer meio convencional ou eletrônico, para fins de estudo e pesquisa, desde que citada a fonte.

\section{FICHA CATALOGRÁFICA}

Del Lama, Lucas Sacchini.

Caracterização e Adaptação do Dosímetro Fricke para Dosimetria em Irradiação de Sangue / Lucas Sacchini Del Lama; Prof. ${ }^{a}$ Dr. ${ }^{a}$ Adelaide de Almeida, orientadora, Prof. Dr. Evamberto Garcia de Góes, coorientador. Ribeirão Preto, 2013. 174 p.

Tese (Doutorado - Programa de Pós-Graduação em Física Aplicada à Medicina e Biologia) - Faculdade de Filosofia, Ciências e Letras de Ribeirão Preto da Universidade de São Paulo.

1. Irradiação de sangue. 2. Controle de qualidade. 3. Dosímetro Fricke Xilenol Gel. 4. Dosimetria. 5. Doença Enxerto Contra Hospedeiro Associada à Transfusão (DECH-AT). 
Nome: Del LAma, Lucas Sacchini

Título: Caracterização e Adaptação do Dosímetro Fricke para Dosimetria em Irradiação de Sangue

Tese apresentada à Faculdade de Filosofia, Ciências e Letras de Ribeirão Preto da Universidade de São Paulo, como parte das exigências para a obtenção do título de Doutor em Ciências.

Aprovado em:

\section{Banca Examinadora}

Prof. Dr. :

Instituição:

Julgamento:

Assinatura:

Prof. Dr. :

Instituição:

Julgamento:

Assinatura:

Prof. Dr. :

Instituição:

Julgamento:

Assinatura:

Prof. Dr. :

Instituição:

Julgamento:

Assinatura:

Prof. Dr. :

Instituição:

Julgamento:

Assinatura: 


\section{Apresentação}

Neste trabalho, termos estrangeiros encontram-se tipografados no estilo itálico. A abreviatura FXG (Fricke Xilenol Gel) é sempre utilizada para designar o dosímetro original, isto é, aquele descrito por Bero e Gilboy et al. em 2000 [1], sendo representado nos gráficos pelo símbolo (o). Os dosímetros FXG testados e proposto nesta tese são simbolizados por $(\triangle)$. Abreviaturas e símbolos podem ser consultados em suas respectivas listas, páginas xv e xix. Ao final deste trabalho encontram-se os Apêndices, bem como o Índice Remissivo com algumas palavras consideradas pertinentes ao tema deste estudo (vide página 149). 
A Deus, minha família, amigos, colegas de trabalho e orientadores pela confiança, força, incentivo, companheirismo e amizade. Sem eles nada disso seria possível! 


\section{Agradecimentos}

Primeiramente gostaria de agradecer minha família por todo o apoio e incentivo nessa caminhada e pela compreensão em momentos de ausência.

Agradeço imensamente à minha orientadora Professora Doutora Adelaide de Almeida por todo o suporte profissional e pela confiança em meu trabalho, além da amizade mútua que foi possível cultivar nesses quatro últimos anos.

Agradeço ao meu coorientador Professor Doutor Evamberto Garcia de Góes por toda a ajuda e amizade recebidos neste Doutorado.

Ao Professor Doutor José Carlos Borges pelas inúmeras críticas e ajudas durante a elaboração deste trabalho.

À Taiga Cazarine pela paciência nesses últimos meses de trabalho e por conduzir minha vida à um novo rumo.

Aos meus "irmãos" Francisco Glaildo Almeida Sampaio, Paulo César Dias Petchevist, Hermes Arytto Salles Kamimura e David Marçal de Oliveira pelas proveitosas discussões acadêmicas e pelo espírito de companheirismo.

Aos meus amigos de Pós-Graduação Aneta Salles Kamimura Chaloupková, Roberto Pitorri, Fernanda Cavalcante e Rodrigo Sato que contribuíram em minhas reflexões científicas e momentos de lazer.

Ao laboratório de Controle de Qualidade (LCQ) e ao Hemocentro de Ribeirão Preto pelo apoio técnico durante meu estágio e pela atenção com minhas necessidades de pesquisa.

Aos técnicos do programa em Física Aplicada à Medicina e Biologia - FAMB (Léo, Serginho, Carlão, Aziani, Élcio) pelas ajudas nos experimentos.

Ao CIDRA e à METROBRAS pelo disponibilidade de equipamentos/detectores.

E aos alunos do programa FAMB que escreveram o modelo em $\mathrm{AT}_{\mathrm{E}} \mathrm{X}$, tomado como base para a confecção deste trabalho (Erbe L. Pandini, Isaias J. A. Soares e Leandro Rizzi). 
"Aprender é

a única coisa de que a mente nunca se cansa, nunca tem medo e nunca se arrepende."

Leonardo da Vinci 


\section{Resumo}

DEL LAMA, L. S. Caracterização e Adaptação do Dosímetro Fricke para Dosimetria em Irradiação de Sangue. 2013. 174 p. Tese (Doutorado - Programa de Pós-Graduação em Física Aplicada à Medicina e Biologia) - Faculdade de Filosofia, Ciências e Letras de Ribeirão Preto da Universidade de São Paulo. 2013.

A Doença Enxerto Contra Hospedeiro Associada à Transfusão (DECH-AT) é uma reação transfusional rara, porém fatal, que ocorre devido à presença de células $\mathrm{T}$ no sangue doado e que pode ser prevenida por meio da irradiação do sangue do doador e de seus componentes antes da transfusão. Assim, o controle de qualidade associado à irradiação do sangue é necessário para se garantir a qualidade do produto transfundido. Neste trabalho é proposta a caracterização e a adaptação da resposta do dosímetro Fricke para uso na dosimetria da irradiação de sangue, mais especificamente o Fricke Xilenol Gel (FXG). Este é um dosímetro químico radiocrômico, que apresenta as vantagens de ser tecido equivalente e de permitir a inferência espacial da dose absorvida dentro da faixa de doses usados na prevenção DECH-AT. Dessa maneira, de modo a possibilitar a inferência de dose absorvida em todo o intervalo utilizado na prevenção da DECH-AT (25 a 50 Gy), o FXG foi caracterizado e adaptado para aplicações dosimétricas envolvendo a irradiação de sangue e derivados. Os resultados com o novo dosímetro apontaram adequabilidade para toda a faixa necessária de doses absorvidas, com sensibilidade e desvanecimento temporal satisfatórios para aplicações rotineiras. Além disso, pela metodologia proposta neste trabalho, foi possível determinar as distribuições espaciais das doses absorvidas com o dosímetro proposto de uma maneira rápida e simples, mostrando assim que este dosímetro apresenta características convenientes para o controle de qualidade para a dosimetria da irradiação de sangue e de hemocomponentes.

Palavras-chave: 1. Irradiação de sangue. 2. Controle de qualidade. 3. Dosímetro Fricke Xilenol Gel. 4. Dosimetria. 5. Doença Enxerto Contra Hospedeiro Associada à Transfusão (DECH-AT). 


\section{Abstract}

DEL LAMA, L. S. Characterization and Adaptation of Fricke Dosimeter for Blood Irradiation Dosimetry. 2013. 174 p. Thesis (Ph.D. - Postgraduate program in Physics Applied to Medicine and Biology) - Faculty of Philosophy, Sciences and Letters of Ribeirão Preto, University of São Paulo. 2013.

The Transfusion Associated Graft Versus Host Disease (TA-GVHD) is a rare transfusion reaction, however fatal, which develops due to the presence of donor $\mathrm{T}$ lymphocytes in the donated blood and that can be avoided by the irradiation of the donated blood blood and blood components prior to transfusion. Thus, the associated quality control of blood irradiation is necessary to guarantee the quality of the transfused product. In this work it is proposed the characterization and adaptation of the response of a Fricke dosimeter to be used for dosimetry of blood irradiation, more especiafically the Fricke Xylenol Gel (FXG). This is a radiochromic chemical dosimeter, which presents advantages to be tissue equivalent and allows the spatial absorbed dose inference. In this manner, in a way to possibilitate the absorbed dose inference in the full interval used for the prevention of the TA-GVHD (25 to $50 \mathrm{~Gy}$ ) the FXG was characterized and adapted for dosimetry applications involving blood and blood components irradiation. The results with the new dosimeter showed adequability for the necessary absorbed doses, with satisfactory sensibility and time fading for routine applications. Furthermore, according to the methodology proposed in this work, it was possible to determine the spatial absorbed dose distributions with the new dosimeter in an fast and simple way, showing that this dosimeter presents convenient characteristics for dosimetry quality control of irradiated the blood and blood components.

Keywords: 1. Blood irradiation. 2. Quality assurance. 3. Fricke Xylenol Gel dosimeter. 4. Dosimetry. 5. Transfusion-Associated Graft versus Host Disease (TAGvHD). 


\section{Lista de Figuras}

1.1 Ilustração exibindo os principais componentes de um irradiador específico de sangue. . . . . . . . . . . . . . . . . . . . . . . . . 15

1.2 Espectros de absorbância de amostras FXG irradiadas de 0 a 10 Gy. . 24

1.3 Gradiente de cores para doses absorvidas de (a) 0 (b) 1 (c) 2 (d) 4 (e) 8 (f) 12 e (g) 16 Gy. . . . . . . . . . . . . . . . . . 24

1.4 Diagrama de níveis de energia de um processo termoluminescente indicando a migração de um elétron da banda de condução para a de valência, após absorção de energia ionizante. . . . . . . . . . . . . . 27

1.5 Ilustrações exibindo o comportamento dos indicadores $\operatorname{RadTag}^{\circledR} \mathrm{e}$ RAD-SuRE ${ }^{\circledR}$ antes e após uma irradiação de 25 Gy. Imagens adaptadas dos respectivos sítios eletrônicos dos fabricantes.

1.6 (a) Sistema dosimétrico DosE-MAP ${ }^{\mathrm{TM}}$ utilizado para dosimetria de irradiadores de sangue. (b) Distribuições espacial das doses absorvidas em irradiador específico de sangue. Imagens disponíveis no sítio eletrônico do fabricante.

2.1 (a) Círculo cromático indicando as cores complementares. (b) Correspondências entre os comprimentos de ondas e as cores do espectro visível. . . . . . . . . . . . . . . . . . . . . . 35

2.2 Esquema ilustrando o sistema de aquisição de imagens digitais utilizado para obtenção dos dados para os dosímetros FXG e filme. . . . . 38

2.3 Esquema ilustrando a obtenção da função de distribuição de borda $(E S F)$ para o FXG calculando-se a média dos perfis de borda em uma cubeta de $1 \mathrm{~cm}$ de espessura. . . . . . . . . . . . . . . . 40

2.4 Ilustrações representando as funções (a) $E S F$, (b) $L S F$ e (c) $M T F$ para a determinação da resolução espacial do sistema dosimétrico. . 40

2.5 Interface gráfica da rotina elaborada em ambiente GUIDE do software MATLAB $^{\circledR}$. . . . . . . . . . . . . . . . . . . . . . . 42

2.6 Fluxograma exibindo os principais processos da rotina escrita em MATLAB ${ }^{\circledR}$ para a dosimetria do irradiador específico. . . . . . . . . . . . 43 
2.7 Fotos exibindo os procedimentos de preparo do dosímetro FXG. . . . 47

2.8 Objeto simulador utilizado durante a dosimetria do irradiador de sangue, composto de uma cubeta de acrílico preenchida com FXG e duas cubetas, também de acrílico, preenchidas com água. . . . . . . . . . . 54

2.9 (a) Objeto simulador de poliestireno utilizado para a obtenção das medidas no irradiador de sangue. (b) Esquema exibindo as placas tipo A e B do OS de poliestireno. . . . . . . . . . . . . . . 57

2.10 Esquema exibindo a obtenção dos planos de distribuição de dose por meio da média das matrizes de dados. . . . . . . . . . . . . . . . . 58

2.11 (a) Ilustração tridimensional dos objetos simulados no código PENELOPE e (b) as angulações utilizadas para reproduzir a rotação do vasilhame. . . . . . . . . . . . . . . . . . 60

3.1 Espectros típicos de absorbância para diferentes doses absorvidas. . . 65

3.2 Valores da variação da Absorbância em função da Dose absorvida para diferentes comprimentos de onda. . . . . . . . . . . . . . 65

3.3 (a) Resposta da dose absorvida inferida versus dose absorvida nominal para o FXG com e sem borbulhamento. Em (b), sensibilidade para os dois tipos de dosímetros. (c) Resíduos dos ajustes lineares das curvas respostas para o FXG com (hachurado) e sem (pontilhado) borbulhamento. . . . . . . . . . . . . . 68

3.4 Caracterização do dosímetro FXG original para diferentes concentrações de $\mathrm{FeSO}_{4}$ em termos de (a) linearidade, (b) sensibilidade, (c) desvanecimento do sinal após a irradiação e (d) absorbância inicial. 70

3.5 Caracterização do dosímetro FXG para diferentes concentrações de gelatina em termos de (a) linearidade, (b) sensibilidade, (c) desvanecimento do sinal após a irradiação e (d) absorbância inicial. . . . . . . 72

3.6 Caracterização do dosímetro FXG para diferentes concentrações de $\mathrm{H}_{2} \mathrm{SO}_{4}$ em termos de (a) linearidade, (b) sensibilidade, (c) desvanecimento do sinal após a irradiação e (d) absorbância inicial. . . . . . . 75 
3.7 Caracterização do dosímetro FXG original para diferentes concentrações de $X O$ em termos de (a) linearidade, (b) sensibilidade, (c) desvanecimento do sinal após a irradiação e (d) absorbância inicial. 77

3.8 Incertezas em função da variação da Absorbância $\Delta \mathrm{A}$, considerando os estudos envolvendo (a) o sulfato ferroso, (b) a gelatina, (c) o ácido sulfúrico e $(\mathrm{d})$ o alaranjado de Xilenol. . . . . . . . . . . . . . . . 80

3.9 Comparação entre os espectros da variação da absorbância para os dosímetros FXG original (linha contínua) e proposto (linha tracejada). 82

3.10 Variação da Absorbância em função da Dose Absorvida para amostras irradiadas a (a) 3 e (b) $23 \pm 1{ }^{\circ} \mathrm{C}$, utilizando-se a técnica espectrofotométrica.

3.11 Respostas relativas em absorbância versus dose absorvida para diversas taxas de doses absorvidas irradiando o FXG com o ${ }^{60}$ Co. (a) FXG original, (b) FXG proposto e (c) filme radiocrômico. . . . . . . . . . . 84

3.12 Respostas relativas em absorbância versus dose absorvida para diversas energias de feixes de fótons para irradiação dos FXG (a) original e (b) proposto.

3.13 Curvas de calibração exibindo resoluções de até 1,0 Gy para as técnicas (a) espectrofotométrica e (b) $C C D$ para os dosímetros FXG original e proposto. . . . . . . . . . . . . . 8 86

3.14 Características do dosímetro FXG original em função do tempo de armazenamento em termos de (a) linearidade, (b) sensibilidade, (c) desvanecimento do sinal após a irradiação e (d) absorbância inicial. 87

3.15 Características do dosímetro FXG proposto em função do tempo de armazenamento em termos de (a) linearidade, (b) sensibilidade, (c) desvanecimento do sinal após a irradiação e (d) absorbância inicial. 89

3.16 Gráfico de resíduos versus dose absorvida (valores estimados) para os dosímetro original e proposto considerando as técnicas (a) espectrofotométrica e (b) CCD . . . . . . . . . . . . . . . . . 91

3.17 Coeficientes de atenuação mássicos, $\mu / \rho$, para diferentes materiais de interesse radiológico normalizados pelos coeficientes de atenuação do sangue obtidos do NIST. . . . . . . . . . . . . . . . . . . . . . . 93 
3.18 Stopping-powers, $S$, para diferentes materiais de interesse radiológico normalizados pelos Stopping-powers. . . . . . . . . . . . . 95

3.19 Porcentagens de taxas de doses no objeto simulador de poliestireno, determinadas após calibração no ${ }^{60}$ Co para (a) os TL's e (b) o filme. . 96

3.20 Distribuição das doses absorvidas percentuais fornecidas pelo fabricante do irradiador Gammacell $3000^{\circledR}$. . . . . . . . . . . . . . . 97

3.21 Diferenças ao se adquirir os dados pelos canais (a) vermelho e (b) verde para o FXG proposto. (c) Distribuição de doses absorvidas utilizando-se média de cinco fotos para o canal vermelho. . . . . . . . 99

3.22 Distribuições percentuais para doses absorvidas obtidas com o dosímetro FXG proposto no irradiador específico. . . . . . . . . . . . . . 101

3.23 Esquema ilustrando o procedimento para obtenção do mapa de isodoses exibido na Figura $3.22(\mathrm{~d})$. . . . . . . . . . . . . . . . 102

3.24 Histogramas das doses absorvidas percentuais para (a) o FXG proposto, (b) o filme, (c) os TL's e (d) os dados do fabricante. . . . . . 103

3.25 Diferenças percentuais entre os mapas de isodoses obtidos com (a) o FXG proposto, (b) o filme e (c) os TL's. . . . . . . . . . . . . 105

3.26 Curvas de isodoses simuladas com o código Penelope para o (a) dosímetro FXG proposto e (b) o sangue, considerando as condições do irradiador Gammacell 3000 ${ }^{\circledR} \ldots$. . . . . . . . . . . . . . . 106

3.27 (a) Mapa e (b) histograma das diferenças percentuais entre os planos simulados para o sangue e FXG utilizando o código PENELOPE. . . . 107

3.28 Curvas de isodoses simuladas com o código PEnELOPE para o sangue, considerando as condições do irradiador Gammacell $3000{ }^{\circledR}$ com uma fonte de ${ }^{60}$ Co. . . . . . . . . . . . . . . . . . . . . 108

3.29 Histogramas das doses absorvidas simuladas com o irradiador de sangue considerando uma fonte de $\left(\right.$ a ${ }^{60}$ Co e (b) ${ }^{137}$ Cs. . . . . . . . . . . 108 


\section{Lista de Tabelas}

3.1 Repetitividade da resposta do dosímetro FXG em função da presença $(0,63 \pm 0,05 \mathrm{mM})$ e ausência de $\mathrm{NaCl}$. . . . . . . . . . . . . . . . 79

3.2 Análise estatística para as curvas de calibração para os dosímetros FXG original e proposto. . . . . . . . . . . . . . . . . . . . . 90

A.1 Substâncias, fórmulas estequiométricas, pesos moleculares, concentrações molares e porcentagens em massa dos componentes presentes no dosímetro Fricke Xilenol Gel. . . . . . . . . . . . . . . . . . . . . . 144 


\section{Lista de Abreviaturas}

$A A B B$

Associação Americana de Bancos de Sangue (American Association of Blood Banks).

$A A P M$

Associação Americana de Físicos em Medicina (American Association of Physicists in Medicine).

ANOVA

Análise de variância (ANalysis Of VAriance).

ANZSBT

Sociedade australiana e neozelandesa de transfusão de sangue (Australian and New Zealand Society of Blood Transfusion).

$B A N G$

Gelatina de bis-acrilamida-nitrogênio (Bis Acrylamide Nitrogen and Gelatin).

$C C D$

Dispositivo de carga acoplada (Charge-Coupled Device).

CI

Câmara de Ionização.

CML

Cultura Mista de Linfócitos.

CNEN

Comissão Nacional de Energia Nuclear.

DECH-AT

Doença Enxerto Contra Hospedeiro Associada à Transfusão.

DFS

Distância Fonte Superfície.

$D O F$

Profundidade de campo (depth of field).

$E D Q M$

Direção Européia da Qualidade dos Medicamentos e Cuidados de Saúde (European Directorate for the Quality of Medicines 83 Healthcare.

ESF

Função de distribuição de borda (Edge Spread Function). 
$F D A$

FFT

FXG

FWHM

GUI

GUIDE

$\mathrm{Hb}$

$H L A$

$I A E A$

$I C R U$

$I M R T$

$L D A$

LET
Administração de Alimentos e Medicamentos (Food and Drug Administration).

Transformada rápida de Fourier (Fast Fourier Transform.

Fricke Xilenol Gel (Fricke Xylenol Gel).

Largura completa na metade do máximo (Full-Widthat-Half-Maximum).

Interface gráfica do utilizador (Graphical User Interface).

Ambiente de projetos para interface gráfica do utilizador (GUI Design Environment).

Hemoglobina.

Sistema antígeno leucocitário humano (Human Leukocyte Antigen).

Agência Internacional de Energia Atômica (International Atomic Energy Agency).

Comissão Internacional para Medidas e Unidades de Radiação (International Commission on Radiation Units).

Radioterapia de Intensidade Modulada (Intensity Modulated Radiotherapy).

Análise por Limite de Diluição (Limiting Dilution Assay.

Transferência linear de energia (Linear Energy Transfer). 
LINAC

$L S F$

MOSFET

MS

MTF

NIST

OS

PENELOPE

PMMA

POP

PSF

$R G B$

R.I. $(i, j)$

SEP

$S S D$

TL

$T L D$
Acelerador linear (LiNear Particle ACcelerator).

Função de dispersão de linha (Line Spread Function).

Transistor de efeito de campo metal-óxido-semicondutor

(Metal Oxide Semiconductor Field Effect Transistor).

Ministério da Saúde.

Função de transferência de modulação (Modulation Transfer Function).

Instituto Norte-Americano de Padrões e Tecnologia ( $\mathrm{Na}$ tional Institute of Standards and Technology).

Objeto Simulador.

Penetração e perda de energia por pósitrons e elétrons (PENetration and Energy LOss of Positrons and Electrons).

PoliMetil MetacrilAto, acrílico.

Procedimento Operacional Padrão.

Função de dispersão pontual (Point Spread Function).

Sistema de cores formado por vermelho, verde e azul (Red Green Blue).

Intensidade relativa (Relative Intensity).

Erro Padrão de Previsão (Standard Error of Prediction).

Distância fonte superfície (Source-Surface Distance).

Dosímetro Termoluminescente.

Dosimetria Termoluminescente (ThermoLuminescent Dosimetry). 
xviii

UV

XO
Radiação Ultra Violeta.

Alaranjado de Xilenol (Xylenol Orange). 


\section{Lista de Símbolos}

$[x]$

$[a ; b]$

${ }^{60} \mathrm{Co}$

${ }^{137} \mathrm{Cs}$

A

$D$

$\dot{D}$

E

$G(i)$

I

$I_{0}$

K

$r$

S

$X$

$Z_{\text {eff }}$

$\Delta \mathrm{A}$

$\phi$

$\gamma$

$\mu / \rho$
Concentração da variável $x$.

Intervalo fechado, em que os símbolos $a$ e $b$ indicam as extremidade do mesmo.

Elemento Cobalto-60.

Elemento Césio-137.

Absorbância.

Dose absorvida.

Taxa de dose absorvida.

Energia.

Rendimento químico do elemento $i$.

Intensidade de luz transmitida.

Intensidade de luz incidente.

Energia cinética liberada por unidade de massa (Kinetic

Energy Released per unit MAss, KERMA).

Coeficiente de correlação linear.

Poder de freamento (stopping power).

Exposição.

Número atômico efetivo.

Variação da absorbância.

Fluência de fótons.

Raios gama.

Coeficiente de atenuação mássico. 
Densidade de massa.

$\sigma_{x}$

Incerteza associada à variável $x$. 


\section{Sumário}

Lista de Figuras $x$

Lista de Tabelas xiv

Lista de Abreviaturas $\quad$ XV

Lista de Símbolos xix

INTRODUÇÃO 2

Relevância . . . . . . . . . . . . . . . . . . . 3

1 ASPECTOS TEÓRICOS 6

1.1 Biologia da DECH-AT . . . . . . . . . . . 6

1.1.1 Viabilidade dos hemocomponentes em função da dose absorvida . . . . . . . . . . . . . . . . 10

1.1.2 Irradiação do sangue e seu controle de qualidade . . . . . . 14

1.2 Dosimetria da radiação ionizante . . . . . . . . . . . . . . . . 17

1.2.1 Dosímetro Fricke . . . . . . . . . . . . . . . . . . . . . . . . 19

1.2.2 Dosímetro Termoluminescente, TL . . . . . . . . . 26

1.2.3 Filme radiocrômico . . . . . . . . . . . . . . . . . 27

1.2.4 Dosimetria de irradiadores de sangue . . . . . . . . . . . . 28

1.3 Simulação Monte Carlo . . . . . . . . . . . . . . . . . . . . . . . 30

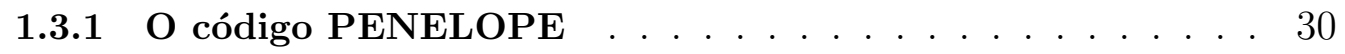

2 MATERIAIS E MÉTODOS 34

2.1 Técnicas e equipamentos utilizados f . . . . . . . . . . . . . . 34

2.1.1 Espectrofotometria . . . . . . . . . . . . . . . 34

2.1.2 Sistema de aquisição digital de imagens . . . . . . . . . . 36

2.1.2.1 Programas de análise . . . . . . . . . . . . . 39

2.1.3 Fontes de radiação e dosimetria de referência . . . . . . . . 44

2.2 Componentes e procedimentos de preparo do FXG . . . . . . 45

2.3 Caracterização do dosímetro FXG . . . . . . . . . . . . . . . . . 47

2.3.1 Linearidade, sensibilidade, desvanecimento e repetitividade 49 
2.3.1.1 Influência do oxigênio . . . . . . . . . . . . 50

2.3.1.2 Influência do sulfato ferroso amoniacal . . . . . . . . 50

2.3.1.3 Influência da gelatina . . . . . . . . . . . . . 51

2.3.1.4 Influência do ácido sulfúrico . . . . . . . . . . . . 51

2.3.1.5 Influência do alaranjado de Xilenol . . . . . . . . . 51

2.3.1.6 Influência do cloreto de sódio . . . . . . . . . . . . 52

2.3.2 Dependência com a temperatura durante a irradiação do FXG . . . . . . . . . . . . . . . . 52

2.3.3 Dependência com a taxa de dose e energia . . . . . . . . . 52

2.3.4 Resolução de resposta do FXG em dose absorvida . . . . . 53

2.3.5 Efeitos devido ao armazenamento do FXG . . . . . . . . 53

2.4 Dosimetria do irradiador de sangue . . . . . . . . . . . . 53

2.4.1 Caracterização dos objetos simuladores de sangue . . . . . 54

2.4.2 Dosimetria de referência . . . . . . . . . . . . . . . . . 55

2.4.2.1 Dosimetria Termoluminescente, TLD . . . . . . . 56

2.4.2.2 Filme radiocrômico . . . . . . . . . . . 58

2.4.2.3 Simulação computacional PENELOPE . . . . . . . . 59

2.5 Análises estatísticas . . . . . . . . . . . . . . . . . . . 61

3 RESULTADOS E DISCUSSÕES 64

3.1 Caracterização do dosímetro FXG . . . . . . . . . . . . 66

3.1.1 Influência do oxigênio . . . . . . . . . . . . . 66

3.1.2 Influência do sulfato ferroso amoniacal . . . . . . . . . . . . 67

3.1.3 Influência da gelatina . . . . . . . . . . . . . . . . . 71

3.1.4 Influência do ácido sulfúrico . . . . . . . . . . . . . . . . 73

3.1.5 Influência do alaranjado de Xilenol . . . . . . . . . . 76

3.1.6 Influência do cloreto de sódio . . . . . . . . . . . . . 78

3.2 Proposição do novo dosímetro FXG . . . . . . . . . . . . . 79

3.2.1 Incertezas associadas à variação da absorbância .... 79

3.2.2 Receita proposta . . . . . . . . . . . . . . 80

3.3 Comparação dos dosímetros FXG proposto e original . . . . . 81

3.3.1 Espectro de absorbância . . . . . . . . . . . . . . . . . 82 
3.3.2 Dependência com a temperatura durante a irradiação do FXG . . . . . . . . . . . . . . . . . 82

3.3.3 Dependência com a taxa de dose absorvida e energia . . . 83

3.3.4 Resolução da resposta em dose absorvida do FXG . . . . . 86

3.3.5 Efeitos devido ao armazenamento do FXG . . . . . . . . . 87

3.3.6 Análise estatística . . . . . . . . . . . . . . . . . . . . . . . . 88

3.3.6.1 Teste ANOVA . . . . . . . . . . . . . 88

3.3.6.2 Erro Padrão de Previsão, SEP . . . . . . . . . . . . 89

3.3.6.3 Coeficiente de correlação linear . . . . . . . . . . . . 90

3.3.6.4 Análise dos resíduos . . . . . . . . . . . . . . . . . 90

3.4 Dosimetria do irradiador específico de sangue . . . . . . . . . . 91

3.4.1 Caracterização teórica dos dosímetros e objetos simuladores de sangue . . . . . . . . . . . . . . . . . . . . . . . . . . 92

3.4.2 Dosimetria de referência . . . . . . . . . . . . . . . . . . . 94

3.4.3 Comparação das curvas de isodoses obtidas pelo FXG com as de referência . . . . . . . . . . . . . . . . . . . . 97

3.4.4 Isodoses utilizando o código PENELOPE . . . . . . . . . . . 104

4 CONCLUSÕES 110

REFERÊNCIAS BIBLIOGRÁFICAS 113

A Características dos componentes do FXG 143

B Plano de Controle de Qualidade para a dosimetria da irradiação $\begin{array}{ll}\text { de sangue } & 145\end{array}$

$\begin{array}{lr}\text { Índice Remissivo } & 150\end{array}$ 


\section{INTRODUÇÃO}

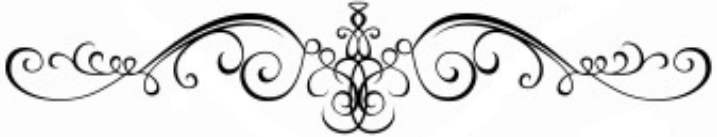




\section{INTRODUÇÃO}

A transfusão de sangue e hemocomponentes tem como finalidade restaurar a população dos elementos do sangue em pacientes que tem comprometimento desses elementos. Contudo, tal ação pode resultar em inúmeras consequências ao receptor, incluindo transferência de agentes patogênicos e indução de respostas imunes. Em ocorrências como estas últimas, os linfócitos transfundidos podem atuar como antígenos e desencadear direta ou indiretamente respostas imunitárias pelos linfócitos do receptor.

Há mais de 40 anos que sangue e alguns de seus hemocomponentes são irradiados antes de transfusões alogênicas para pacientes imunossuprimidos [2]. Devido à sua energia, a radiação ionizante é capaz de produzir quebras nas moléculas de DNA, presentes nas células $\mathrm{T}$, impedindo uma resposta imune destas células contra o receptor [3]. Tal procedimento objetiva evitar a reação transfusional Doença Enxerto Contra Hospedeiro Associada à Transfusão (DECH-AT). Assim, hemocomponentes que podem conter células $\mathrm{T}$ viáveis devem ser irradiados antes de serem transfundidos, especialmente em pacientes imunocomprometidos [4-6].

Atualmente, existem duas opções para se irradiar sangue: equipamentos de radioterapia, como aceleradores lineares e unidades de cobalto, e irradiadores específicos de células. Entretanto, na ausência de um irradiador específico, alternativas como raios $\mathrm{X}$, gerados por aceleradores lineares, ou raios $\gamma$, emitidos por fontes de ${ }^{60} \mathrm{Co}$, podem ser utilizados para a citada finalidade [5,7-10]. Nesses casos, bolsas de hemocomponentes são colocadas entre duas camadas de material equivalente a tecido mole com espessuras suficientes para que a primeira promova o equilíbrio eletrônico dos elétrons secundários e a segunda funcione também como objeto retroespalhador. Equivalentemente à essa prática, em muitas instituições brasileiras que irradiam sangue com equipamentos teleterápicos, lotes inteiros de hemocomponentes são irradiados dentro de cubas de acrílico preenchidas com água a fim de se conseguir uma homogeneização adequada da distribuição da dose absorvida da radiação incidente

Uma das desvantagens do uso das unidades de teleterapia nos procedimentos associados à irradiação de sangue é a falta de padronização deste processo. De fato, como diferentes volumes são normalmente irradiados, a distribuição da dose absorvida pelo sangue pode variar significativamente em cada caso. Desta forma, o uso de 
equipamentos teleterápicos não é recomendado para a irradiação de sangue, devido à incerteza associada à dose absorvida [11]. Em contrapartida, nos irradiadores específicos o volume alvo é constante, mas para se obter homogeneidade na distribuição da dose absorvida as bolsas devem girar frente à fonte de radiação durante todo o tempo da irradiação.

A Food and Drug Administration (FDA), a American Association of Blood Banks $(A A B B)$ e o Ministério da Saúde (MS) recomendam uma dose mínima de 2500 cGy no plano médio do volume do sangue irradiado [12-14]. Já o guia Europeu (European Directorate for the Quality of Medicines \& HealthCare, EDQM) e os britânicos (Guidelines on the use of irradiated blood components prepared by the British Committee for Standards in Haematology blood transfusion task force) além de recomendarem uma dose mínima de 2500 cGy no plano médio do volume irradiado, estabeleceram que a dose máxima não deve exceder 5000 cGy [15-17]. Todavia, não existe um protocolo de controle de qualidade com recomendações específicas sobre o sistema de detecção e sobre o objeto simulador que devem ser utilizados nas determinações da taxa de dose absorvida e da distribuição espacial desta no volume irradiado.

\section{Relevância}

De acordo com a literatura, podem ser citados ao menos três casos de DECH-AT em pacientes que receberam sangue irradiado entre 1500 e 2000 cGy. Os volumes de sangue transfundidos para esses pacientes foram irradiados utilizando-se raios X, de aceleradores lineares teleterápicos [18,19], e raios $\gamma$, de um irradiador específico [20]. Nesses três casos, a dose absorvida não foi confirmada e a suas distribuições nos volumes dos sangues irradiados com os aceleradores lineares não foram determinadas.

Independentemente do equipamento utilizado, para garantir que nenhuma parte do sangue receba menos que a dose mínima necessária para a prevenção da DECHAT, a distribuição espacial da dose absorvida pelo sangue deve ser determinada periodicamente [6]. Além disso, a taxa de dose também deve ser determinada e confirmada sazonalmente em cada lote de bolsas de sangue irradiado, especialmente para os equipamentos que fazem uso de fontes radioativas $\left({ }^{137} \mathrm{Cs}\right.$ e $\left.{ }^{60} \mathrm{Co}\right)$.

Sistemas frequentemente utilizados para dosimetria incluem os filmes radiocrômi- 
cos e os dosímetros termoluminescentes (TL's), porém ambos apresentam limitações práticas tais como: sensibilidade à temperatura de irradiação, restrito intervalo de linearidade para doses absorvidas e exigências de equipamentos específicos para medição. Além disso, embora vários trabalhos publicados em periódicos tenham focado os aspectos técnicos do processo da irradiação do sangue, poucos deram atenção aos detalhes econômicos e de gerenciamento dessa prática [9]. Assim, devido à essas limitações de dosimetria e pelo que foi exposto nos parágrafos precedentes, é necessário implementar o controle de qualidade associado ao sangue irradiado com equipamentos de teleterapia e com irradiadores específicos, de maneira a promover a qualidade do sangue e de seus componentes irradiados. Portanto, o detector e as sistemáticas de análise, armazenamento, gerenciamento e disponibilização dos dados dosimétricos, terão como principal meta garantir o controle da qualidade associado à irradiação do sangue. Ademais, visando a praticidade, o método de detecção será configurado de modo que a resposta e a preparação do dosímetro possam ser realizadas nas próprias dependências de um centro de hemoterapia.

Tendo em vista a "dosimetria" normalmente realizada nas irradiações de sangue (com indicadores qualitativos de radiação, como por exemplo o $\operatorname{RadTag}^{\circledR}$ e o RADSURE $\left.{ }^{\circledR}\right)$ e a necessidade médica em determinar a verdadeira dose absorvida pelo mesmo, os objetivos gerais deste trabalho foram o da caracterização e adaptação do dosímetro Fricke Xilenol Gel (FXG) em aplicações associadas ao controle de qualidade da irradiação do sangue e seus derivados. Uma vez que este dosímetro já apresenta características dosimétricas muito próximas aos do tecido mole [1,21-23], suas propriedades espectrofotométricas e dosimétricas foram estudadas, de modo a adaptá-lo às necessidades relacionadas à irradiação do sangue. Portanto, este trabalho utilizou uma variação do dosímetro FXG para realizar as medições da dose absorvida e sua distribuição no sangue irradiado. O dosímetro aqui proposto apresentou características mais adequadas para a dosimetria em procedimentos da irradiação do sangue e vantagens sobre dosímetros comerciais, tais como os termoluminescentes e filmes radiocrômicos. Nesse sentido, tanto o dosímetro FXG quanto a sistemática de auferição aqui propostos mostraram-se apropriados para o controle da qualidade dos hemocomponentes irradiados, no processo de prevenção da DECH-AT. 


\section{ASPECTOS TEÓRICOS}




\section{Capítulo}

\section{ASPECTOS TEÓRICOS}

A Doença Enxerto Contra Hospedeiro Associada à Transfusão (DECH-AT) ${ }^{1}$ era considerada uma reação relativamente rara, mesmo em pacientes imunocomprometidos. Contudo, a partir da década de 1990, esta doença adquiriu significativa importância já que começou a afetar não somente pacientes imunocomprometidos, como era inicialmente reportado [24-28], mas também aqueles supostamente imunocompetentes [29-34], devido ao desenvolvimento de novas técnicas de transfusão, de transplantes, de práticas cirúrgicas e ao aumento de doações sanguíneas entre familiares, sendo estas últimas como medidas de segurança contra doenças potencialmente transmissíveis por doadores randômicos [29,35].

\subsection{Biologia da DECH-AT}

A DECH-AT é mediada pelos linfócitos T imunocompetentes contidos no sangue do doador, os quais podem enxertar-se, proliferar-se e montar uma resposta imunológica grave contra os tecidos do hospedeiro [27]. Assim, a citada doença é induzida por transfusão alogênica ${ }^{2}$ e se torna uma enfermidade bastante séria nos pacientes por ela acometidos, pois na maioria das ocasiões, o diagnóstico é tardiamente realizado devido a semelhança de seus sintomas com os de reações alérgicas medicamentosas ou com os de infecções virais [36-38]. Como resultado do tardio diagnóstico, a doença evolui e promove a diminuição das células de defesa do receptor. Por conta desta queda de imunidade, o paciente torna-se altamente susceptível

\footnotetext{
${ }^{1}$ A abreviatura DEvH-AT (Doença Enxerto versus Hospedeiro Associada à Transfusão) também é um termo frequentemente encontrado na literatura nacional.

${ }^{2}$ Transfusão de hemocomponentes em que o receptor e o doador são pessoas diferentes.
} 
à infecções oportunistas, proporcionando taxas de mortalidade tão elevadas quanto $90 \%[32,33,39]$, mesmo com o uso de medicamentos imunossupressores, como a ciclosporina, ou do uso de anticorpo monoclonal como anti-CD3 (OKT3). De fato, o prognóstico dessa doença é muito pobre, com apenas alguns poucos casos de sobreviventes na literatura [36,40-42]. Assim, uma vez que a DECH-AT não responde com sucesso a nenhum tipo de tratamento [43], a sua prevenção requer que células $\mathrm{T}$ auxiliares $\left(\mathrm{CD} 4^{+}\right)$e supressoras $\left(\mathrm{CD} 8^{+}\right)$sejam inativadas antes da transfusão de hemocomponentes. Estudos iniciais tiveram como objetivo a diminuição ou inibição das células T presentes nas bolsas de sangue doado antes da transfusão. Embora o número de casos tenha diminuído com a redução dos leucócitos do sangue, alguns relatos de DECH-AT foram reportados após a transfusão de produtos leucoreduzidos $[39,44,45]$. Outras abordagens tentaram identificar métodos para inibir a capacidade proliferativa dos linfócitos $\mathrm{T}$, sem afetar as demais células do sangue. Como será visto mais adiante, o método mais aceito e empregado para tal finalidade é o da utilização da radiação ionizante para irradiação das bolsas de sangue.

Um dos primeiros casos reportados de DECH-AT foi descrito em 1965 por HathaWAy et al [24] em duas crianças com suspeita de imunodeficiência congênita, após transfusão de sangue fresco. Inicialmente, o dano era atribuído à infiltração dos linfócitos T no tecido do hospedeiro, contudo estudos propuseram que a destruição tecidual estava ligada à presença de $\operatorname{citocinas}^{3}$ [46]. Dados indicam que a produção de citocinas é bem menos sensível à radiação ionizante do que a capacidade proliferativa, evidenciando que esta radiação interrompe a divisão celular, mas não leva à uma imediata apoptose ${ }^{4}$ dos linfócitos que ainda não foram estimulados [47].

Apesar dos inúmeros experimentos com modelos animais e das experiências clínicas rotineiras, o limiar da concentração de células $\mathrm{T}$ necessário para estimular o surgimento da DECH-AT não é conhecido [20]. Com base nos relatos de casos dessa doença em humanos, estima-se que uma concentração de $10^{4}$ até $10^{7}$ células T infundidas por quilograma de peso do receptor é suficiente para causar a DECHAT $[25,44]$. Na verdade, o limiar de células T necessário para desencadear a doença pode ser atribuída aos vários graus de disparidade entre Antígenos de Leucócitos

\footnotetext{
${ }^{3}$ Grupo de peptídeos envolvidos na emissão de sinais entre as células do sistema imunitário durante o desencadeamento das respostas imunes.

${ }^{4}$ Morte celular programada.
} 
Humanos $(H L A)$. As populações que apresentam elevado nível de homozigosidade $H L A$ são predispostas à DECH-AT [48]. Além dessa predisposição genética, os casamentos co-sanguíneos, a tendência de transfundir sangue fresco entre familiares e a qualidade dos serviços prestados por bancos de sangue inadequados tornam a população mais vulnerável [34].

Estatisticamente, a DECH-AT é mais comum em pacientes com idade superior a 50 anos e os principais fatores de risco associados ao seu desencadeamento incluem transfusão de sangue fresco, consanguinidade, realização de cirurgias cardíacas, doenças neoplásicas e ser do sexo masculino [49]. A maioria dos casos de DECH-AT foi observada após a tranfusão de sangue fresco, os quais possuem maior concentração de leucócitos viáveis [38]. De fato, segundo Онто et al [30], em torno de $62 \%$ dos casos de DECH-AT no Japão ocorreram após a transfusão de sangue fresco (sendo o restante dos casos devido a outros fatores como baixa variabilidade genética da população), ao passo de que nos EUA, a porcentagem de DECH-AT devido à transfusão de sangue fresco pode ser de até $90 \%$ [29]. Assim, uma medida recomendada com o objetivo de diminuir a incidência da DECH-AT é procurar não utilizar sangue ou hemocomponentes frescos (menos do que 03 dias de estocagem) [30,50], com exceção das plaquetas [51], uma vez que o número de linfócitos viáveis é inversamente proporcional ao tempo de estocagem $[3,52]$.

A homogeneidade das populações, tais como a japonesa, é outro importante fator para a incidência de DECH-AT em uma população [53]. Deveras, o risco que os japoneses apresentam de serem acometidos por essa doença após transfusão de sangue de doadores não aparentados é de 1:874 [35], podendo chegar até 1:658 [54] quando a transfusão é seguida de cirurgia cardíaca. Devido ao elevado número de ocorrências de DECH-AT entre os japoneses, de 5 a 10 vezes maior em comparação à outros países [32,39] - nos Estados Unidos, esse número gira em torno de 1:7174 [35] - , a irradiação universal de todas as bolsas de sangue e hemocomponentes foi implementada no Japão no início de 2000 pelo Ministério da Saúde, Trabalho e BemEstar desse país e, a partir de então, nenhum caso mais foi reportado [53]. De fato, a irradiação universal já foi defendida por alguns [37], embora os riscos dessa prática devam ser ponderados pelo aumento das concentrações principalmente de potássio e consequente redução do tempo de estocagem para 28 dias. 
Experimentos em animais indicam que três fatores influenciam a ocorrência de DECH-AT: a condição imunológica do receptor, a disparidade entre os $H L A$ do doador e do receptor e a concentração e viabilidade dos leucócitos infundidos [37]. A DECH-AT se manifesta em pacientes com diversos históricos clínicos de tumores sólidos (neuroblastoma, carcinoma de pulmão, glioblastoma, linfoma de Hodgkin, sarcoma, carcinoma cervical e adenocarcinoma renal), transplante de medula óssea e em pacientes pós-cirúrgicos (cirurgia cardíaca, vascular, gastro-intestinal, abdominal e transplante de fígado) $[7,28,54,55]$. Efetivamente, a maioria dos casos de DECH-AT está relacionada com pacientes que apresentam neoplasias malignas hematológicas, em especial os pacientes com linfoma de Hodgkin devido ao estado imunocomprometido [25, 26]. Pacientes com linfoma não Hodgkin apresentam menores riscos, porém casos já foram reportados [56,57]. Curiosamente, a AIDS (Síndrome da Imunodeficiência Adquirida, SIDA) não aparenta ser um fator de risco para o desenvolvimento da DECH-AT [58], embora um caso já tenha sido reportado [59], embora alguns autores consideram que a DECH-AT seja subdiagnosticada em pacientes aidéticos, devido à complexidade dos sintomas apresentados [27,60].

Como os hemocomponentes transfundidos não são normalmente testados quanto ao tipo de $H L A$, pode ocorrer tanto uma resposta do receptor contra as células do sangue do doador quanto uma resposta do doador contra o receptor, dependendo de fatores tais como o número de leucócitos presentes no sangue doado, a compatibilidade entre os $H L A$ e a competência imunológica dos linfócitos do receptor e doador [61]. Assim, a fim de se evitar completamente a DECH-AT, seria necessário removerem todas as células $\mathrm{T}$ dos hemocomponentes a serem transfundidos. Entretanto, até o presente, não existe método disponível capaz de executar esse grau de leucoredução. Alternativas como estocagem prolongada a $4{ }^{\circ} \mathrm{C}$, glicerolização, congelamento a $-70{ }^{\circ} \mathrm{C}$ e subsequente deglicerolização, podem reduzir de 1 a $2 \log _{10}$ (de 90 a 99 \%) os leucócitos existentes, mas não os elimina totalmente, sendo que células remanescentes já mostraram-se mitoticamente ativas [62]. O uso de filtros para remoção de leucócitos mais adequados [45], como os de segunda e terceira geração, não consegue uma leucoredução maior que 3 a $4 \log _{10}$ (maior que $99 \%$ ). Embora a utilização de produtos leucoreduzidos tenha diminuído a incidência dessa doença, foram reportados casos de DECH-AT após a transfusão de hemocomponentes com 
número reduzido de leucócitos [45].

\subsubsection{Viabilidade dos hemocomponentes em função da dose absorvida}

Uma vez que não se consegue uma remoção física das células $\mathrm{T}$ em quantidade suficiente para a prevenção da DECH-AT, é necessário aplicar outra metodologia preventiva, a qual se baseia no desarmamento do potencial proliferativo dessas células. O único método aceito para se evitar a DECH-AT é a irradiação do sangue e de seus componentes antes da transfusão [4-6]. O uso da radiação ionizante é capaz de produzir quebras cromossômicas e inibir atividades mitóticas e transformações blásticas das células $\mathrm{T}$ [63], impedindo o ataque destas células contra receptores susceptíveis. Assim, a finalidade da radiação ionizante é a de danificar o material genético dos linfócitos $\mathrm{T}$, presentes no sangue do doador de modo a inibir sua replicação e anular a resposta enxerto versus hospedeiro [3].

A radiação ionizante aumenta a probabilidade de ocorrências de transformações malignas em células nucleadas, fato que fora observado logo após a descoberta dos raios X por Wilhelm Röntgen, em 1895. Apesar dos possíveis riscos radioinduzidos, tais como geração de células cancerígenas, e de ruptura do agente plastificante das bolsas de sangue, nenhum deles é provável de ocorrer para as doses absorvidas corriqueiramente empregadas. A Administração de Alimentos e Medicamentos (Food and Drug Administration, FDA) afirma que existe um risco muito pequeno de ocorrência de algum tipo de aberração genética [12], sendo mais provável que as doses absorvidas empregadas na Hemoterapia promovam a morte celular do que alguma alteração genética [17]. Além desses, outro risco eminente ao se irradiar sangue diz respeito à reativação de vírus latentes, podendo constituir um risco teórico ao paciente [64]. Porém, nenhum caso já foi reportado na literatura, especialmente levando-se em conta que as doses empregadas na irradiação de sangue em muito ultrapassam as necessárias para esse tipo de reativação $[12,16]$.

Tanto os raios $\mathrm{X}$ quanto os raios $\gamma$ apresentam os mesmos efeitos biológicos quando a mesma dose é administrada [65-67], todavia, o uso de irradiadores que empregam a radiação $\mathrm{X}$ apresenta benefícios em termos de radioproteção devido ao fato de não utilizarem fontes radioativas, necessitarem de menos requerimentos regulatórios, menos treinamento e menor potencial para possíveis usos bioterroristas. 
Estudos realizados sobre a radiosensibilidade das células $\mathrm{T}$ aos raios $\mathrm{X}$ e aos raios $\gamma$, mostraram que é necessária uma dose mínima de 2500 cGy ou 25 Gy para a prevenção da DECH-AT $[3,31,68]$. Esses estudos foram conduzidos utilizando-se células T isoladas a partir de unidades ou bolsas irradiadas de concentrado de hemácias $[3,68]$, bem como de unidades de plaquetas obtidas por aférese ${ }^{5}$ [31]. Porém, em adição aos danos causados nas células $\mathrm{T}$, a irradiação também produz danos em outros hemocomponentes, como em hemácias, plaquetas, granulócitos e plasma [5].

Os linfócitos T são mais radiosensíveis do que os demais componentes do sangue [4]. Todavia, a irradiação de hemácias promove pequenas diminuições da capacidade de reparação celular em $24 \mathrm{~h}$ de estocagem, tanto in vitro quanto in vivo [65, 69-71]. De fato, a viabilidade das hemácias irradiadas, após 24 h de recuperação, é reduzida na estocagem quando comparada com hemácias não irradiadas $[65,69]$. Contudo, o dano causado às hemacias irradiadas tem como origem secundária a degradação das células brancas e pode ser amenizado pela leucoredução previamente à irradiação/estocagem [71,72]. Fora isso, sabe-se que a irradiação de sangue acarreta aumentos na hemólise e no potássio sobrenadante, além de reduções nas concentrações de adenosina trifosfato (ATP), de lactato desidrogenase (LDH), de $\mathrm{Na}^{+}$e redução do $\mathrm{pH}$ nas bolsas estocadas [65, 69,72,73], embora efeitos no $\mathrm{pH}$, no consumo de glicose e nos níveis de ATP e de 2,3 DPG não tenham riscos clínicos significantes [74]. Dessa forma, os componentes irradiados possuem um menor tempo de estocagem, devido à preocupação em diminuir a transfusão de bolsas com níveis muito elevados de potássio e hemoglobina livre. A título de exemplo, concentrados de hemácias podem ser estocados por até 28 dias após a irradiação, desde que não ultrapassem o período normal de estocagem (42 dias) [12]. Essa limitação relacionada aos hemocomponentes irradiados, ocorre em razão da diminuição do nível de reparo em 24 h comparado com produtos não irradiados [75].

Ao contrário das células nucleadas do sangue, as hemácias são muito radioresistentes e nelas não foram reportados efeitos adversos à radiação em doses menores que 50 Gy, principalmente nível de potássio extracelular $\left(\mathrm{K}^{+}\right)$e hemoglobina livre [76], embora alguns pesquisadores já tenham encontrado danos in vivo e in vitro, em hemácias irradiadas com doses de 30 Gy [69]. Os estudos que avaliaram

\footnotetext{
${ }^{5}$ Através da doação por aférese é possível retirar apenas uma das células do sangue total.
} 
os efeitos da radiação sobre as hemácias utilizando doses de 30 e 40 Gy e períodos de armazenamento de 35 e 40 dias após a irradiação, mostraram um aumento significativo (de até $100 \%$ ) no nível de potássio extracelular nas bolsas irradiadas, em relação aquelas de controle [65,69,72,77]. Apesar das consequências dessas mudanças na concentração de potássio in vivo serem pouco conhecidas, sugere-se que algum grau de dano adicional ocorra nas hemácias após a irradiação, tornando-se evidente após um longo período de armazenamento e da dose absorvida [78]. A transfusão de bolsas da sangue com elevadas concentrações de $\mathrm{K}^{+}$são preocupantes, em razão dos riscos cardíacos envolvidos ao transiente estado de hipercalemia ${ }^{6}$ [79], especialmente considerando-se que o paciente pode ir a óbito [80]. Assim, foi recomendado que bolsas de hemácias irradiadas sejam lavadas ${ }^{7}$ previamente às transfusões intrauterinas, neonatais ou pediátricas [73,81,82]. Fora isso, existem filtros que possuem a finalidade de reduzir a concentração de $\mathrm{K}^{+}$nas bolsas de hemácias, usados após a irradiação [83]. Todavia, estudos envolvendo a transfusão de concentrado de hemácias não revelaram alterações significativas na concentração de potássio extracelular no sangue do receptor, uma vez que o potássio tende a se distribuir rapidamente em todo o volume sanguíneo do receptor [84].

Além das hemácias, outros hemocomponentes também devem ser irradiados para a prevenção da DECH-AT, tais como as plaquetas e os granulócitos. Ao contrário das hemácias que possuem um longo tempo de estocagem (no máximo de até 42 dias), plaquetas e granulócitos devem ser irradiados e transfundidos em menos de 24 $\mathrm{h}^{8}$ após o seu preparo, independentemente se foram submetidos à irradiação ionizante [13]. Segundo alguns autores, plaquetas e granulócitos não são suficientemente afetados de modo a terem seus tempos de armazenamento encurtados [5,85], embora alguns trabalhos presentes na literatura sejam conflitantes quanto à qualidade desses produtos pós-irradiados $[77,86-91]$.

O sucesso na prevenção da DECH-AT depende da seleção do grupo de pacientes de risco que deve receber produtos de sangue irradiados e da dose absorvida a ser

\footnotetext{
${ }^{6}$ A hipercalemia é caracterizada pela grande quantidade de potássio no sangue.

${ }^{7} \mathrm{O}$ concentrado de hemácias lavadas é obtido após a "lavagem" com solução isotônica para remoção de plasma e leucócitos residuais.

${ }^{8}$ Dependendo do sistema de coleta, o tempo de armazenamento das plaquetas pode estender-se até 5 dias.
} 
utilizada. Esta última é aquela que eliminaria a habilidade mitótica dos linfócitos T, sem prejudicar a funcionalidade das demais células do sangue. Estudos mostraram que doses absorvidas entre 5 e 15 Gy seriam suficientes para eliminar a reatividade alogênica utilizando células T em Cultura Mista de Linfócitos (CML) [63, 92] e, por conta disso, muitos bancos de sangue começaram a irradiar seus produtos 15 Gy. A técnica CML é útil como um experimento representativo da habilidade apresentada pelos linfócitos T de enxertarem-se no hospedeiro e mediarem a reação enxerto-versus-hospedeiro, mas não consegue detectar reduções superior a $2 \log _{10}$ na capacidade de proliferação das células T $[92,93]$. Assim, apesar da técnica CML não mostrar a presença de células T, casos de DECH-AT foram relatados no passado. Um deles ocorreu em uma criança com leucemia que recebeu transfusão de plaquetas e hemácias irradiadas através de raios X de um acelerador linear com doses de 15 Gy [19]. Outro caso, envolveu um paciente que recebeu transplante de medula óssea, seguido de uma transfusão de hemácias irradiadas com dose absorvida de 20 Gy [29]. Atualmente, conforme mencionado anteriormente, recomenda-se que o sangue seja irradiado com uma dose mínima de 25 Gy, a qual é capaz de promover uma redução maior do que $2 \log _{10}$ de células $\mathrm{T}[12-15]^{9}$.

Após as ocorrências de DECH-AT com sangue irradiado, a influência da radiação $\gamma$ também foi investigada na desativação das células T, através da aplicação da técnica Análise por Limite de Diluição $(L D A)$ [3,94]. Outros estudos fizeram uso dessa técnica em concentrados de hemácias, os quais foram irradiados utilizando-se um irradiador específico com fonte de ${ }^{137} \mathrm{Cs}$ [3] e um equipamento de telecobaltoterapia [95]. Os resultados das bolsas irradiadas, permitiu observar o crescimento de células $\mathrm{T}$ em todos os experimentos $L D A$ que envolviam dose absorvida igual ou superior a 15 Gy, ao contrário dos resultados apresentados pela técnica CML, que mostrou uma completa ausência das atividades mitóticas das células T, com doses absorvidas acima deste valor $[63,76]$. Dessa maneira, recomendou-se o uso de uma dose absorvida mínima de pelo menos 25 Gy.

A partir dos estudos anteriores, que faziam uso da técnica $L D A$, a associação americana de bancos de sangue $(A A B B)$ e o guia britânico de controle de qualidade

\footnotetext{
${ }^{9} \mathrm{Em} 2000$, a $F D A$ emitiu um guia piloto para programas de licenciamento em irradiação de sangue que foi revogado em 2006, mantendo o guia de 1993 como o último documento público/oficial com relação a esse assunto.
} 
na Hemoterapia passaram a recomendar uma dose absorvida mínima de 25 Gy no plano central da bolsa irradiada e não menor do que 15 Gy em todo o volume da bolsa tanto para raios X quanto raios $\gamma[13,16]$. Analogamente, os guias europeus e australiano/neozelandês estabeleceram que a irradiação deveria ser de, no mínimo, 25 Gy e não mais do que 50 Gy $[15,17,88,96]$. O guia japonês foi mais amplo e passou a recomendar um intervalo de doses absorvidas que compreendiam de 15 a 50 Gy em todo o volume irradiado [51].

Além do uso da radiação ionizante da ordem de megavoltagem, existem outras metodologias para a prevenção da DECH-AT, as quais empregam radiação ultravioleta, UV, [97,98] ou até luz visível [99], combinada com substâncias fotoreativas para reduzir a ativação dos linfócitos do doador. O emprego de radiação UV para a irradiação de sangue já vem sendo estudado desde o final da década de 1980 [100], de modo que FAst e outros pesquisadores [98] sugeriram que tal tipo de metodologia possa ser utilizada com sucesso na prevenção da DECH-AT, frente a irradiação do sangue por raios X ou $\gamma[61,101,102]$. Todavia, tais sistemas ainda não são aprovados pelas agências reguladoras em Hematologia.

\subsubsection{Irradiação do sangue e seu controle de qualidade}

Em torno de $10 \%$ de todo o sangue doado nos EUA é irradiado rotineiramente por bancos de sangue e instituições médicas [103]. Como mencionado anteriormente, hemocomponentes celulares devem ser irradiados antes da transfusão em pacientes que corram risco de desenvolver a DECH-AT, tais como em transfusões intra-uterinas, pacientes que receberão componentes doados por familiares e que receberão sangue selecionado em função da compatibilidade de $H L A$ [13], embora alguns pesquisadores defendam que todo hemocomponente transfundido deveria ser irradiado [104]. Por motivos mencionados anteriormente, o guia japonês é mais amplo e também recomenda a irradiação de sangue para pacientes submetidos a cirurgias cardiovasculares e de câncer [51].

No passado [2,105,106], o sangue era irradiado extracorporalmente, utilizando-se do fluxo por tubos em um irradiador de ${ }^{90} \mathrm{Sr}$. Tais irradiações tinham por finalidade prevenir a rejeição de órgãos transplantados e matar células malignas no sangue de modo a preservar a medula óssea. Atualmente, os irradiadores de sangue incorporam 
de uma a quatro fontes radioativas, em geral de ${ }^{137} \mathrm{Cs}$, cada uma com atividade entre 22 e 89 TBq (595 a 2405 Ci) [107], permitindo a obtenção de taxas de doses asorvidas superiores a $5000 \mathrm{cGy} / \mathrm{min}$. Como as fontes encontram-se dispostas verticalmente ao redor ou tangenciando o volume irradiado, os hemocomponentes devem rotacionar constantemente de modo a se obter uma maior homogeneidade das doses absorvidas no volume irradiado [108], Figura 1.1.

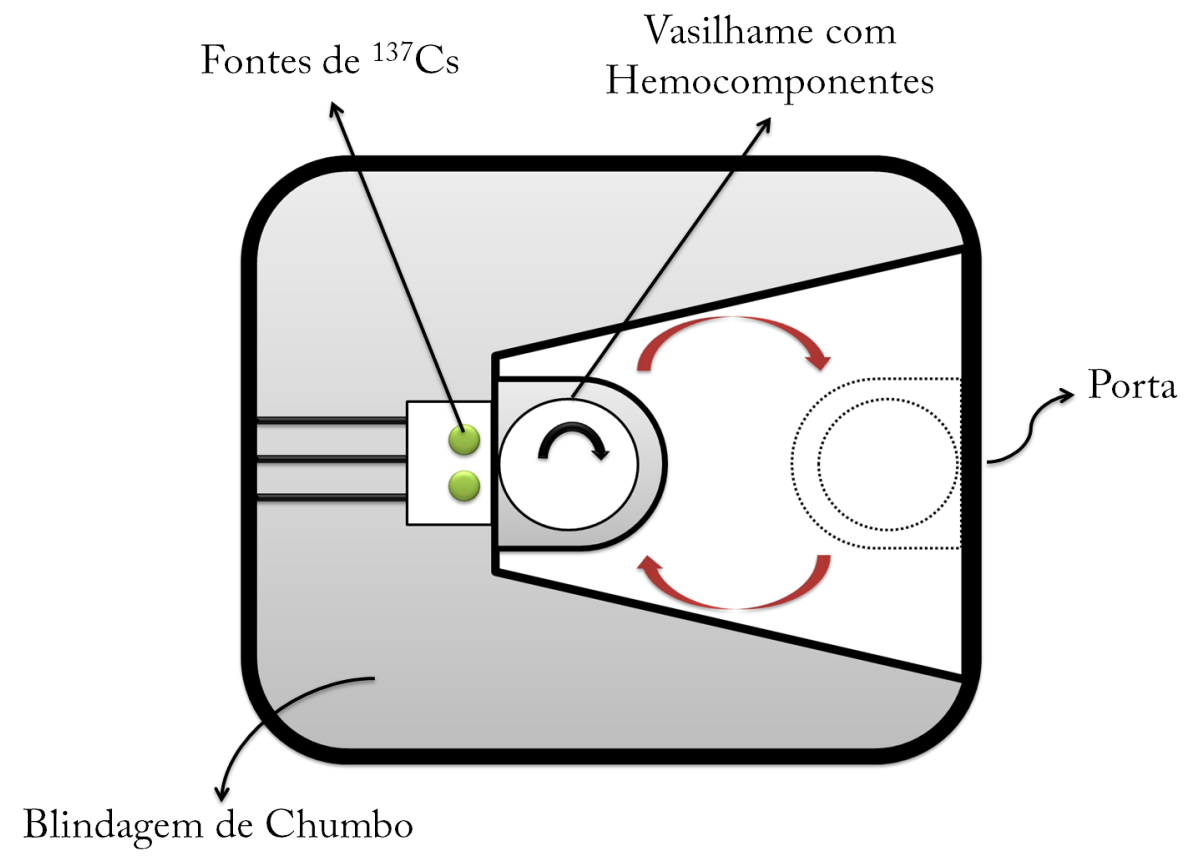

Figura 1.1. Ilustração exibindo os principais componentes de um irradiador específico de sangue.

De acordo com a comissão reguladora nuclear dos EUA (US Nuclear Regulatory Commission - NRC), os irradiadores de sangue que empregam ${ }^{137} \mathrm{Cs}$ como fonte emissora de radiação, constituem mais de $90 \%$ dos equipamentos para a irradiação do sangue, visto que são os equipamentos mais confiáveis, eficientes e de baixa manutenção. Deveras, apenas nos EUA existem cerca de 575 irradiadores de sangue que empregam cloreto de césio $(\mathrm{CsCl}$ ) para suas irradiações [109]. Todavia, apesar de tal popularidade, a utilização do pó de $\mathrm{CsCl}$ tem despertado grande preocupação, em razão desse composto ser solúvel em água e, portanto, facilmente dispersível. Além disso, outro concernimento está relacionado às conhecidas "dirty bombs", nas quais esse composto pode ser agregado por terroristas à artefatos explosivos [110].

Recentemente um relatório feito pela academia nacional de ciências dos Estados 
Unidos (US National Academy of Sciences) recomendou a substituição dos irradiadores que empregam fontes radioativas $\gamma$ pelos que utilizam raios $\mathrm{X}$ gerados por aceleradores lineares [111]. Porém, devido à dificuldade no manejo das fontes e, principalmente, quanto ao seu transporte, o descomissionamento de um irradiador de sangue que faz uso de CsCl pode ser superior a US\$ 100.000,00 dólares, podendo chegar a até US\$ 1.000.000,00 de dólares, segundo um encontro público realizado pela $A A B B$, devido a maior parte dos containers aprovados para transportar esse tipo de carga, já estarem em desuso [112].

Apesar do custo da aquisição de irradiadores específicos de sangue, uma das principais vantagens do seu uso é a possibilidade deles irradiarem os produtos de sangue imediatamente antes da transfusão, evitando-se efeitos adicionais nos hemocomponentes irradiados, devido ao processo de armazenamento. Além disso, devido as altas taxas de dose, estes equipamentos são capazes de oferecer doses absorvidas como 25 Gy em poucos minutos. Neste caso, evita-se também, qualquer influência da temperatura ambiente ou da agitação nas bolsas pelo transporte, sobre a qualidade dos produtos irradiados.

Embora tenham vantagens, a maioria das instituições médicas brasileiras não tem condições de absorver os custos de um irradiador específico de sangue, devendo buscar alternativas para o atendimento de suas necessidades. Por outro lado, o país conta com uma expressiva rede de serviços de teleterapia, a qual pode ser utilizada para suprir a demanda de sangue irradiado $[5,7,9]$. Contudo, os equipamentos de teleterapia, ao contrário dos irradiadores específicos, não são projetados com a finalidade de irradiar sangue, assim um maior tempo de exposição é necessário para a liberação da dose mínima necessária para a prevenção da DECH-AT. Dependendo da taxa de dose absorvida da fonte de ${ }^{60} \mathrm{Co}$ (de 0,5 a 4,0 Gy por minuto, aproximadamente) e da dose absorvida preconizada, o tempo de exposição pode estender-se além de uma hora. Outra desvantagem do uso dos serviços de teleterapia para a irradiação de sangue é a falta de horários ociosos dentro de suas rotinas, impedindo que os produtos sejam transfundidos imediatamente após a irradiação. Neste caso, um tempo de armazenamento dos produtos irradiados, de pelo menos quinze horas, pode ser necessário antes da transfusão. Ademais, uma vez que os serviços de teleterapia não dispõem de horários ociosos em sua programação, é necessário minimizar 
o tempo de uso do equipamento, o que pode ser conseguido por meio da irradiação dos produtos em um único lote, o que pode gerar gradientes consideráveis de dose no volume irradiado.

Vários sistemas dosimétricos já foram propostos e/ou empregados para o controle de qualidade no processo de irradiação de sangue: TLD [4,113], o próprio Fricke em forma de solução aquosa [114], dosímetros colorimétricos [115] e filme radiocrômico [8]. Dosímetros de estado sólido também já foram sugeridos e incluem os feitos de polimetacrilato (do tipo red perspex) [4], de alanina [10,116], os do tipo MOSFET [5] e os diodos [117]. Em geral, o uso de vários desses dosímetros requer equipamento oneroso e altamente especializado e, consequentemente, serviços externos são contratados a fim de se realizar parcial ou completamente essa verificação.

Independentemente do tipo de hemocomponente irradiado, é necessário uniformizar a dose absorvida pelo sangue, garantindo que o mínimo desta seja fornecido a todo e qualquer elemento do volume irradiado. Isto somente é possível através da determinação da distribuição da dose absorvida em cada volume irradiado. As medidas do programa de controle de qualidade incluem a distribuição espacial da dose absorvida e a determinação da taxa de dose proporcionadas pelo irradiador, o ajuste do tempo de irradiação devido ao decaimento da fonte, a mensuração da radiação de fuga, a determinação da precisão do tempo de irradiação e a operação da mesa rotativa. Assim, de acordo com os objetivos estabelecidos, o estudo dosimétrico proposto neste trabalho viabilizará a padronização da irradiação do sangue, através do uso dos equipamentos de telecobaltoterapia e irradiador específico, promovendo a qualidade do sangue irradiado.

\subsection{Dosimetria da radiação ionizante}

A radiação ionizante é toda energia transferida no espaço capaz de liberar elétrons e/ou íons de um átomo ou de uma molécula em um meio. Comparada com outros tipos de radiação (UV, vísivel, infra-vermelho, por exemplo), a radiação ionizante deposita relativamente grandes porções de energia em pequenos volumes de matéria, o que pode resultar em danos consideráveis.

Sob o ponto de vista da etimologia da palavra, a dosimetria é a mensuração 
da dose absorvida $(D)$ ou da taxa de dose $(\dot{D})$ resultante da interação da radiação ionizante com a matéria [118]. Dessa maneira, a dosimetria tem como principal função determinar as grandezas de maior relevância radiológica tais como exposição $(X)$, kerma $(K)$, fluência, $(\phi)$ ou, mais comumente, a dose absorvida $D$, como escolhida neste trabalho. De modo geral, existem duas considerações distintas acerca da dosimetria: a de descrever o feixe de radiação propriamente dito ${ }^{10}$ e a de descrever a quantidade de energia que a radiação tem condições de depositar em um meio ${ }^{11}$.

Para as ocasiões em que a radiação quebra as ligações químicas, elétrons e/ou íons são gerados com determinada energia cinética, de modo que essas partículas podem produzir excitações ou até mesmo outras ionizações. Esse fenômeno está relacionado com outra grandeza radiológica chamada de transferência linear de energia (Linear Energy Transfer, LET), a qual descreve o valor esperado da quantidade de energia que a radiação transfere por unidade de caminho percorrido e, consequentemente, a sua capacidade em produzir danos no meio.

Para as áreas que aplicam a radiação ionizante para fins de terapia ou de diagnóstico, o principal fator de preocupação sobre seu uso está relacionado com a quantidade de energia que é transferida para o paciente. De modo a quantificar a energia efetivamente absorvida pelo meio, a Comissão Internacional para Medidas e Unidades de Radiação (International Commition on Radiation Units and Measurements, ICRU, em inglês), em especial no relatório de 1980 [119], definiu a dose absorvida como sendo:

$$
D=\frac{d E}{d m}
$$

tal que $d E$ representa a energia absorvida ao meio e $d m$ a massa num volume $d V$, onde a energia foi depositada. A unidade antiga de dose absorvida era o rad (do inglês radiation absorved dose), que encontra-se em desuso devido a adoção do $\operatorname{gray}^{12}$, Gy, de forma que 1 Gy $=100 \mathrm{rad}$.

\footnotetext{
${ }^{10}$ Tais grandezas são denominadas Grandezas Radiométricas e, dentre outras, incluem a fluência $(\phi)$, a distribuição da fluência em função da energia $\left(\phi_{E}\right)$, a distribuição da fluência em função do ângulo sólido $\left(\phi_{\omega}\right)$ e suas respectivas taxas $\dot{\phi}, \dot{\phi_{E}}$ e $\dot{\phi}_{\omega}$.

${ }^{11}$ Tais grandezas são denominadas Grandezas Dosimétricas e, dentre outras, incluem a dose absorvida $D$, a taxa de dose $(\dot{D})$, o KERMA $(K)$ e a exposição $(X)$.

${ }^{12}$ Gray é uma unidade especial do Sistema Internacional de medidas, que representa a quantidade de energia em J absorvida por unidade de massa em $\mathrm{kg}$.
} 
A fim de realizar a dosimetria de determinada aplicação da radiação ionizante, há a necessidade de se utilizar um dosímetro, isto é, um dispositivo capaz de fornecer um valor de leitura $l$, diretamente proporcional à dose absorvida pela radiação ionizante $D$, em seu volume sensível $V$. Idealmente, $l$ é proporcional à $D$, de modo que cada elemento infinitesimal do $V$ tenha igual influência sobre o valor de $l$ e a dose absorvida possa ser considerada a média das doses absorvidas no volume total.

\subsubsection{Dosímetro Fricke}

A energia proveniente de um feixe radioativo pode ser parcial ou totalmente absorvida por um meio, podendo produzir alterações no meio e possibilitar a inferência da dose absorvida pelo material [120]. Quase todo efeito conhecido da radiação ionizante na matéria, seja físico, químico ou biológico, já foi sugerido como base para dosimetria, especialmente se ele for suficientemente mensurável, estável e caracterizável em medições dosimétricas. Dessa forma, dependendo do tipo de fenômeno desencadeado, pode-se elaborar um sistema dosimétrico capaz de mensurar tais alterações e a partir delas determinar a dose absorvida em certo volume. Um tipo de dosímetro capaz de fazer tal determinação é o dosímetro Fricke, nas quais alterações químicas são correlacionadas à dose absorvida.

A solução Fricke é classificada como um sistema padrão de referência de dosimetria química segundo a norma ISO/ASTM 51261 [121]. De fato, devido à sua exatidão, reprodutibilidade e linearidade, o dosímetro Fricke é usado em diversos laboratórios padrão [122]. A dosimetria Fricke é capaz de proporcionar medidas com precisão de até $0,1 \%$ para fótons e elétrons de altas energias [123]. Além disso, o referido dosímetro já tem sido recomendado tanto pela Associação Americana de Físicos em Medicina (American Association of Physicists in Medicine, AAPM) quanto pela $I C R U$, como um método alternativo para a determinação e calibração da dose absorvida na água.

Um dosímetro é dito absoluto caso ele possa ser utilizado para medir dose absorvida nele depositada sem requerer calibração em um campo de radiação conhecido. O dosímetro Fricke normalmente é empregado como um dosímetro relativo, pois sua resposta absoluta depende da determinação da grandeza rendimento químico, $G\left(F e^{+3}\right)$, a qual deve ser precisamente determinada em laboratórios padrões [124]. 
A dosimetria química mostra-se muito versátil já que, além de abranger um extenso intervalo de doses, $\left[10^{-1} ; 10^{8}\right]$ Gy, ela apresenta dosímetros que podem tomar inúmeras formas, como os filmes, e volumes, como as soluções Fricke. Estes últimos dosímetros já foram considerados como um dos poucos dosímetros precisos o suficiente para serem adotados como absoluto, o que é alcançado através do número de íons de interesse formados por pacotes de $100 \mathrm{eV}$ de energia absorvida (valorG) $[118,125]$.

Embora um dos mais rotineiramente utilizados dosímetros químicos para energias da ordem de megavoltagem seja o filme radiocrômico, o Fricke é considerado o mais relevante para a determinação da dose absorvida em tecido mole ou em material biológico [118]. Tal atribuição se deve ao seu número atômico efetivo $\left(Z_{\text {eff }} \approx\right.$ $7,75)$ e à sua densidade $\left(\rho \approx 1,05 \mathrm{~g} / \mathrm{cm}^{3}\right)$, os quais são parâmetros semelhantes aos da água $\left(Z_{e f f} \approx 7,42\right.$ e $\left.\rho=1,00 \mathrm{~g} / \mathrm{cm}^{3}\right)$. Por conta de tais semelhanças, alguns fatores de correção podem ser desprezados no momento do cálculo da dose absorvida, principalmente no intervalo de interesse prático na Radioterapia - até $\approx 15$ Gy.

A preparação do primeiro dosímetro químico é atribuída a Fricke, em 1927 [126]. Originalmente, sua composição era constituída apenas de sulfato ferroso, de ácido sulfúrico e de água. Ao longo das últimas décadas, esse dosímetro sofreu melhorias por meio da adição ou da substituição de alguns de seus componentes, especialmente na década de 1980, quando se deu o início da dosimetria Fricke gel [127]. Dos atuais modos de preparo, um do mais utilizados é o Fricke Xilenol Gel (FXG), que consiste na adição da gelatina de pele de porco e do corante alaranjado de Xilenol $(X O)$ na solução de 1927 [1,128].

O princípio básico tanto da solução original, quanto da solução modificada FXG, é a oxidação, radio-induzida pela radiação ionizante, dos íons ferrosos $\left(\mathrm{Fe}^{+2}\right)$ em íons férricos $\left(\mathrm{Fe}^{+3}\right)$, sendo a concentração desses últimos relacionada com a dose absorvida [129]. O FXG apresenta vantagens frente ao dosímetro original devido a maior estabilidade quanto à oxidação natural dos íons ferrosos, além de também possuir maior resolução espacial [130].

Assim como o corpo humano, que é constituído de 60-70\% de água [131], os dosímetros químicos Fricke apresentam, tipicamente, mais do que $75 \%$ de água em sua constituição [132], de modo que ele interage semelhantemente ao tecido mole 
e, portanto, serve também como um objeto simulador. Dessa forma, a radiação ionizante ao interagir com a água pode promover o surgimento de íons $\mathrm{H}^{+}, \mathrm{OH}^{-}$, $e_{\mathrm{aq}}{ }^{-}$, além de produtos secundários, pelo processo conhecido como radiólise da água, reações $1.2-1.4$.

$$
\begin{aligned}
\mathrm{H}_{2} \mathrm{O}+\mathrm{e}_{a q}^{-} & \rightarrow \mathrm{H}+\mathrm{OH}^{-} \\
\mathrm{HO}_{2} & \rightarrow \mathrm{H}^{+}+\mathrm{O}_{2}^{-} \\
\mathrm{OH} & \rightarrow \mathrm{H}^{+}+\mathrm{O}^{-}
\end{aligned}
$$

Em um breve espaço de tempo, esses radicais livres formados tendem a se distribuir homogeneamente no meio, produzindo outras reações na solução. Essas reações podem formar íons de interesse e, dependendo do tipo de dosímetro químico utilizado, auxiliam na determinação da dose absorvida. Assim, considerando-se a concentração dos íons de interesse, no caso íons $\mathrm{Fe}^{+3}$ para os do tipo Fricke, esta pode ser quantificada por meio de técnicas como a espectroscopia UV-visível, e possibilitar a determinação da dose absorvida pelo dosímetro [118]. A geração dos íons $\mathrm{Fe}^{+3}$ ocorre a partir dos produtos das reações $(1.2)-(1.4)$, sendo o complexo $X O-\mathrm{Fe}^{+3}$ formado segundo as reações (1.5) - (1.9) [128].

$$
\begin{aligned}
\mathrm{HO}+\mathrm{XO} & \rightarrow \mathrm{HOXO} \\
\mathrm{HOXO}+\mathrm{Fe}^{+2} & \rightarrow \mathrm{HOXO}^{-}+\mathrm{Fe}^{+3} \\
\mathrm{HO}+\mathrm{Fe}^{+2} & \rightarrow \mathrm{OH}^{-}+\mathrm{Fe}^{+3} \\
\mathrm{Fe}^{+2}+\mathrm{HO}_{2} & \rightarrow \mathrm{Fe}^{+3}+\mathrm{HO}_{2}^{-} \\
\mathrm{Fe}^{+2}+\mathrm{H}_{2} \mathrm{O}_{2} & \rightarrow \mathrm{Fe}^{+3}+\mathrm{OH}+\mathrm{OH}^{-}
\end{aligned}
$$

O uso de géis na dosimetria teve seu início na década de 1950 com o estudo das propriedades químicas desses compostos após irradiação [133, 134], contudo todo o potencial de dosimetria bi e tridimensional não pode ser explorado até o surgimento de computadores e sistemas de aquisição de dados mais modernos. Em comparação com os dosímetros termoluminescentes, TL's, filmes radiográficos e câmaras de ionização, os dosímetros géis são considerados menos energeticamente dependentes e 
mais tecido-equivalentes [135]. Inúmeros trabalhos propuseram o uso de diferentes agentes gelificantes tais como Agar e Agarose [136-139], todavia esses agentes não apresentam características práticas para métodos ópticos devido à translucidez, além de possuírem pontos de fusão relativamente elevados $\left(\approx 90^{\circ}\right)$, que promove a redução do oxigênio dissolvido na amostra e aumenta as taxas de auto-oxidação [140,141]. Agentes poli(ácool-vinílicos) também eram bastante utilizados devido à sua baixa inatividade e baixos coeficientes de difusão para os dosímetros do tipo FXG. Porém, esse agente gelificante poderia ser problemático para o preparo de grandes amostras, uma vez que sua elevada viscosidade promovia o acúmulo de bolhas de ar em seu volume. Diferentemente desses materiais, a gelatina de pele de porco apresenta a melhor sensibilidade e linearidade, além de adequada transparência óptica [1]. De fato, a gelatina de origem animal é o agente mais comumente empregado para o preparo de dosímetros do tipo gel. Concentrações da ordem de $5 \%$ são normalmente utilizadas e permitem níveis aceitáveis de transmissão óptica para a realização de medidas. As gelatinas mais comuns são as de origem suína, com uma força de geleificação de 300 Bloom $^{13}$. Dependendo da formulação, tal tipo de gelatina derrete entre 30 e $45{ }^{\circ} \mathrm{C}$.

O Fricke em sua forma gel foi o primeiro sistema dosimétrico a oferecer a possibilidade de mapear tridimensionalmente a dose absorvida de maneiras não destrutiva e não invasiva $[127,142]$. Neste sistema, a ressonância magnética era empregada para mapear os íons férricos no volume amostral irradiado. Apesar dos resultados obtidos pela ressonância magnética nuclear serem bastante promissores, alguns parâmetros podem prejudicar determinada pesquisa. Como o dosímetro FXG apresenta difusão espacial dos íons férricos formados ao longo do tempo, a análise do dosímetro deve ser realizada logo após a irradiação a fim de se obter uma maior fidelidade à irradiação e uma maior resolução espacial. Contudo, as imagens de ressonância magnética necessitam de certo tempo para serem adquiridas, principalmente quando a espessura da fatia adquirida é da ordem de milímetros, de maneira que os efeitos da difusão passam a não serem mais negligenciáveis [138, 143].

A detecção dos íons férricos em soluções Fricke contendo o $X O$ deu-se início na década de 1970 com GuPTA [144]. Em 1985, o mesmo autor descreveu um

\footnotetext{
${ }^{13}$ Relacionado com a elasticidade mecânica do gel.
} 
dosímetro mais sensível do que a solução Fricke original ao adicionar alaranjado de Xilenol e ácido benzóico durante o seu preparo [145]. Tal dosímetro era voltado para baixos valores de doses absorvidas ( $<$ 1,0 Gy) e promovia alterações na coloração do dosímetro, o que possibilitou a partir de então, o desenvolvimento de técnicas ópticas para inferência da dose absorvida. Outra versão modificada do dosímetro Fricke, na qual a absorção da radiação também promovia alterações na coloração, foi proposta em 1991 [137] em que a gelatina também passou a ser incorporada. Com a adição da gelatina de origem orgânica, o ácido benzóico passou a ser inutilizado visto que os compostos orgânicos presentes na gelatina promoviam aumento no rendimento dos íons férricos [146]. A adição de alaranjado de Xilenol à solução Fricke também permitiu detecções mais sensíveis e reprodutíveis, para os íons férricos gerados em comprimentos de onda do visível [147]. O coeficiente de extinção molar na região espectral do verde $(520-570 \mathrm{~nm})$ é aproximadamente sete vezes maior do que o coeficiente do íon férrico na região UV em $304 \mathrm{~nm}$ [148]. Além disso, o complexo $X O-\mathrm{Fe}^{+3}$ mostrou menor difusão em matrizes géis do que os íons férricos livres [149].

No caso específico do FXG, os íons férricos formam o complexo com o Alaranjado de Xilenol, $X O-\mathrm{Fe}^{+3}$, o qual aumenta a absorbância do dosímetro em comprimentos de onda próximos a $585 \mathrm{~nm}$, Figura 1.2. Quanto maior a concentração do complexo, maior é a absorbância da amostra, o que é refletido na coloração do FXG, a qual altera-se do laranja para o roxo, Figura 1.3.

Sabe-se que pequenas quantidades de impurezas podem afetar a resposta do dosímetro Fricke. Dentre essas, existem basicamente dois tipos: as de origem orgânica e as de residuais. A fim de remediar as influências causadas pelas impurezas orgânicas, que tendem a aumentar o rendimento químico dos íons férricos, $G\left(F e^{+3}\right)$, o cloreto de sódio foi proposto à solução na metade do século passado [151]. As impurezas residuais provenientes principalmente do ácido sulfúrico promovem a redução do $G e\left(F e^{+3}\right)$ e de modo a minimizarem tal efeito, dois métodos foram propostos: 1) a pré irradiação do ácido sulfúrico e 2) a adição de peróxido de hidrogênio $\left(\mathrm{H}_{2} \mathrm{O}_{2}\right)$ e de permanganato de potássio $\left(\mathrm{KMnO}_{4}\right)$ à solução [152]. Muitas vezes esses procedimentos de controle de impurezas são omitidos ou caíram em desuso, devido ao fato de que a dosimetria Fricke passou a ser muito utilizada como dosimetria relativa e ao fato de que os produtos empregados atualmente possuem maior nível de pureza. 


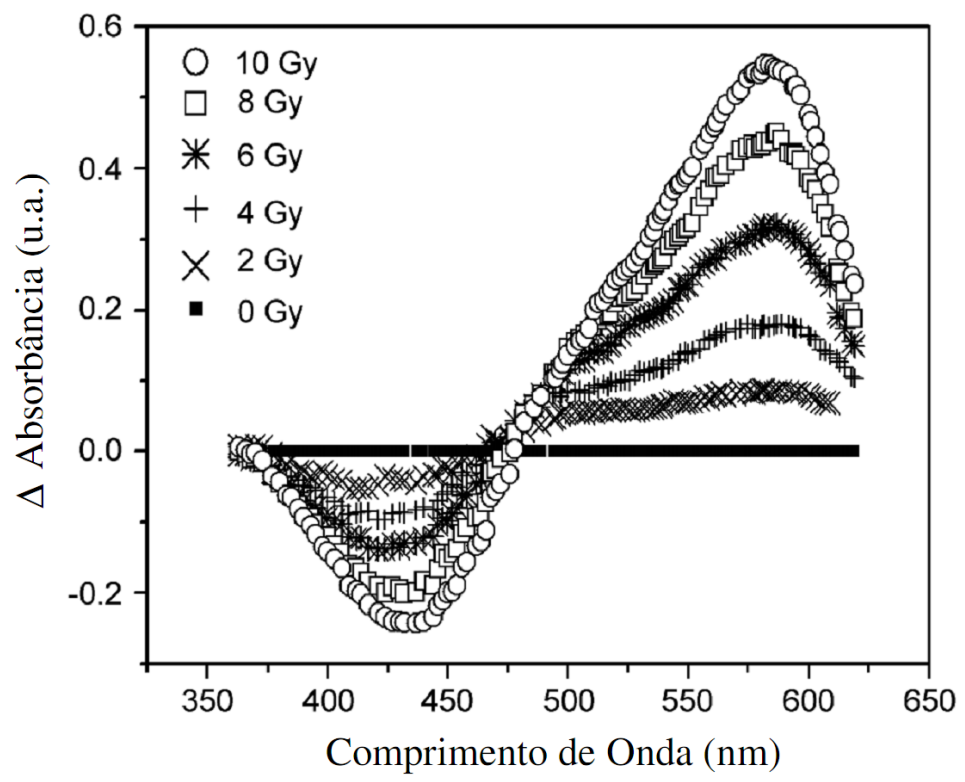

Figura 1.2. Espectros de absorbância de amostras FXG irradiadas de 0 a 10 Gy [150].

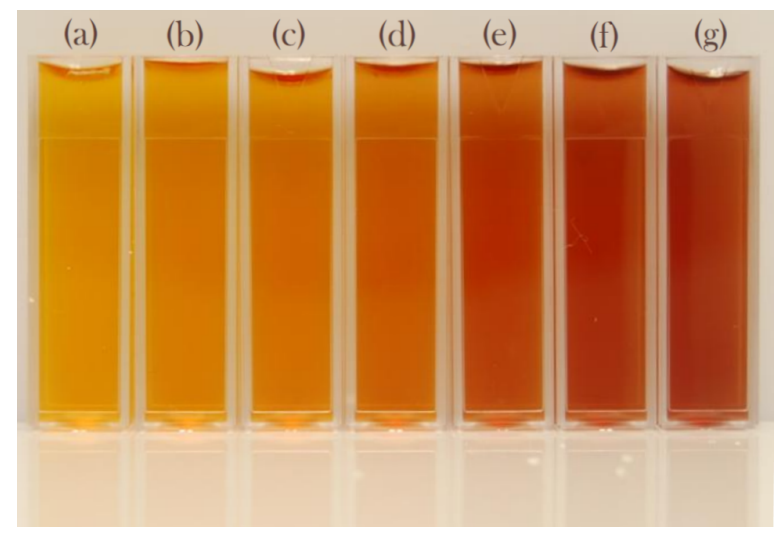

Figura 1.3. Gradiente de cores para doses absorvidas de (a) 0 (b) 1 (c) 2 (d) 4 (e) 8 (f) 12 e (g) 16 Gy.

A dosimetria por meio do Fricke Xilenol Gel é uma maneira eficaz e exata tanto para quantificar quanto para mapear a distribuição espacial da dose absorvida num meio bi ou tridimensional [153-155]. Dentre os dosímetros químicos, o FXG é considerado um dos mais estáveis [154], contudo para medições de elevadas resoluções, tais como 0,1 Gy e 0,1 mm, as concentrações de cada componente devem ser cuidadosamente levadas em consideração, além de fatores como temperatura e tempo pós-radiação, cruciais para o coeficiente de difusão [146,156,157]. Na Física Médica (Radioterapia, Radiologia, etc.), o FXG possui a vantagem de ter número atômico e densidade $\left(7,75\right.$ e $\left.1,05 \mathrm{~g} / \mathrm{cm}^{3}\right)$, muito próximos aos do tecido mole $(7,64$ e 1,04 
$\mathrm{g} / \mathrm{cm}^{3}$ ), tornando-o prático para a obtenção dos principais parâmetros dosimétricos utilizados $[158,159]$. Assim como o Fricke, o FXG é considerado radiologicamente tecido equivalente [160], porém o dosímetro em forma gel é aproximadamente 19 vezes mais sensível [161].

O FXG mostrou-se muito útil, inclusive, para a dosimetria de pequenos campos de radiação, como aqueles necessários em radiocirurgias [162,163], bem como para medidas com feixes de menores energias $[21,164,165]$ utilizados em terapias superficiais e de ortovoltagem. Ademais, outra característica bastante significativa com relação à dosimetria está relacionada com a sua independência quanto à taxa de dose absorvida e qualidade dos feixes comumente empregados na rotina clínica [136, 166, 167].

A dosimetria com o Fricke Xilenol Gel possui a versatilidade de poder ser realizada por diferentes técnicas. No início do século XX, sua análise consistia apenas na titulação da solução, porém com a evolução da tecnologia, outros métodos começaram a ser utilizados, tais como a espectroscopia UV-visível [1,124,138,154,162, 168], a ressonância magnética $[127,136,140,146,154,169,170]$ e a fotoacústica $[130,150]$. Além dessas, outra técnica bastante sensível para a investigação da resposta dos dosímetros do tipo FXG é a que faz uso de imagens com câmera provida de sensor de dispositivo de carga acoplada Charge-Coupled Device, CCD) [22,157,163,171-174], que apresenta-se mais promissora sobretudo para determinações da distribuição espacial da dose absorvida em um meio.

Uma limitação associada aos dosímetros do tipo Fricke é que os íons férricos podem se difundir quase que livremente na solução, o que pode acarretar em borramento na distribuição espacial da dose e consequente perda de resolução espacial [175], de modo que a análise do dosímetro deve ser realizada em um período "curto" de tempo após a irradiação [176]. O problema de difusão dos íons férricos foi remediado pela incorporação de materiais de polimerização radio-induzida no dosímetro [177-180], o que proporcionou maior estabilidade na distribuição espacial da dose absorvida ao longo do tempo. Porém, tais dosímetros devem ser obrigatoriamente lidos com ressonância magnética, além de apresentarem limitações como a complexidade de preparo ${ }^{14}$, a baixa estabilidade antes da irradiação e a toxicidade

\footnotetext{
${ }^{14} \mathrm{~A}$ presença de oxigênio na solução inibe a resposta do dosímetro.
} 
apresentada, em geral, pelos polímeros utilizados. Outra alternativa adotada para diminuir esses efeitos da difusão foi a adição do alaranjado de Xilenol no dosímetro por Gupta et al., que também tinha a função de pigmentar os íons férricos no espectro visível [145]. Além dessas alternativas experimentais, métodos teóricos para corrigirem a difusão dos íons férricos na solução já foram propostos [156,181]. Apesar da limitação da difusão dos íons nas amostras irradiadas, os dosímetros do tipo FXG continuam sendo estudados e acredita-se que provavelmente serão considerados como padrões de comparação para novos sistemas géis de dosimetria, devido tanto à facilidade de preparação quanto à sensibilidade em termos de dose absorvida [147].

\subsubsection{Dosímetro Termoluminescente, TL}

Alguns materiais, ao serem aquecidos, apresentam a propriedade de emitirem luz proporcionalmente à energia absorvida pela radiação ionizante. Esse fenômeno de emissão de luz pelo aquecimento é conhecido como termoluminescência e possibilita a quantificação da dose absorvida pelo material. O princípio físico que embasa o fenômeno da termoluminescência é a teoria de bandas, nas quais bandas de valência e de condução explicam a absorção da energia e consequente liberação de luz. Em geral, os materiais termoluminescentes apresentam bandas de valência completas e de conduções vazias, sendo separadas por uma faixa de estados energéticos não permitidos, a banda proibida, Figura 1.4. Ao ser exposto à radiação ionizante, alguns elétrons da banda de valência do material são excitados para a banda de condução. Embora a maioria dos elétrons retorne imediatamente ao seu estado fundamental (banda de valência), alguns acabam sendo presos nas armadilhas criadas pela dopagem. Em "baixas" temperaturas, tais como a ambiente, essas armadilhas possuem energia potencial suficientes para impedir que o elétron escape, porém, quando o material recebe energia térmica, os elétrons armadilhados são novamente excitados para a banda de condução e migram para a banda de valência com consequente emissão de fótons de luz. Assim, a emissão de luz, quando quantificada, pode ser utilizada para inferir a energia absorvida pelo material, pois esta é proporcional ao número de elétrons armadilhados.

Os dosímetros LiF:Mg,Ti (TLD-100) são materiais tecido-equivalente que apresentam adequadas sensibilidade e resolução espacial $(\approx 3 \mathrm{~mm})$ para o mapeamento 


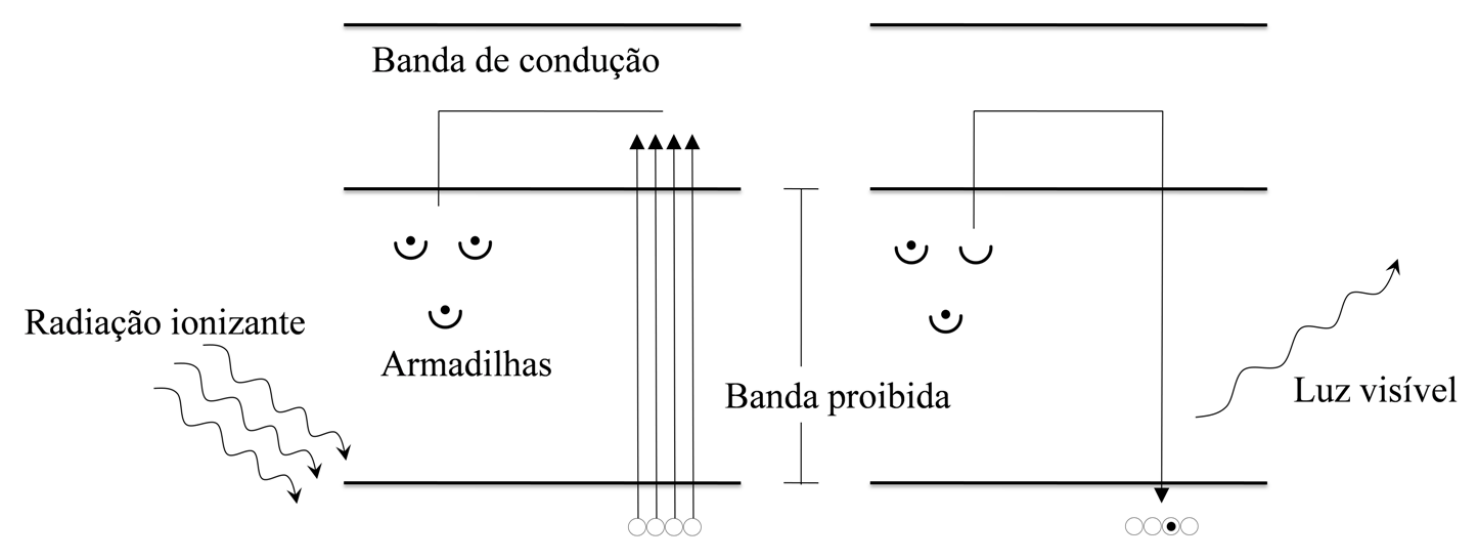

Banda de valência

Figura 1.4. Diagrama de níveis de energia de um processo termoluminescente indicando a migração de um elétron da banda de condução para a de valência, após absorção de energia ionizante.

da distribuição de doses absorvidas em certo volume irradiado. Por apresentar número atômico efetivo próximo ao do tecido humano, o TL $\left(Z_{e f f}=8,2\right)$ é bastante empregado na dosimetria médica. Além disso, sua resposta praticamente independe da taxa de dose e da energia utilizada para irradiação [4], embora alguns autores já tenham reportado fatores de correção para energias entre 1,03 - 1,10 para fótons $\gamma$ [182]. Em termos de aplicação, a dosimetria termoluminescente (TLD) é mais comumente utilizada para a monitoração de doses efetivas individuais em planos de radioproteção pessoal, calibração de equipamentos e quantificação de doses em pequenos volumes $\left(1\right.$ a $3 \mathrm{~mm}^{3}$ ) [120].

\subsubsection{Filme radiocrômico}

A dosimetria utilizando filmes radiocrômicos é frequentemente realizada para determinar as distribuições das doses absorvidas em feixes de elétrons, contudo para feixes de fótons tal prática não era amplamente aceita até o final do século XX [183], devido a dependência da sensibilidade dos filmes com a energia dos fótons incidentes. No passado diferenças de até $30 \%$ eram reportadas entre os resultados de câmaras de ionização e filmes, para porcentagens de dose profunda (PDP's) acima de $15 \mathrm{~cm}$ [184]. Essas diferenças eram atribuídas aos átomos de prata presentes nas emulsões que compunham os filmes, uma vez que tais átomos tendem a interagir mais fortemente com os fótons de baixas energias $(<200 \mathrm{keV})$ por efeito fotoelé- 
trico, diferentemente de fótons de alta energia que interagem primariamente por efeito Compton, acarretando em respostas acima das esperadas. Alguns autores já fizeram uma extensa revisão sobre o assunto e descreveram recomendações de como minimizar esse problema [185].

Com os avanços da dosimetria por filmes radiocrômicos, houve a necessidade de desenvolver um filme que pudesse substituir os antigos filmes radiográficos e que pudesse ser adequadamente utilizado em novas e mais modernas aplicações. Nesse sentido, os filmes do tipo EBT (GAFChromic ${ }^{\mathrm{TM}}$, International Specialty Products, New Jersey, EUA) merecem destaque, por suas características dosimétricas e praticidades. Os filmes GAFCHROMIC ${ }^{\mathrm{TM}}$ vêm sendo constantemente empregados na dosimetria e no controle de qualidade de equipamentos médicos, envolvendo feixes de fótons e elétrons, na Radioterapia de Intensidade Modulada (IMRT, em inglês), em radiocirurgias e em braquiterapia como ferramenta para controle de qualidade [186-190]. Além das aplicações médicas, esse tipo de filme também já foi utilizado para fins de pesquisas em experimentos envolvendo pequenos animais [191]. Esses filmes já foram extensamente estudados e caracterizados para medidas de doses absorvidas [192,193] e seu uso é justificado pelo fato desse tipo de filme ser equivalente ao tecido mole, ser independente da taxa de dose, não apresentar sensibilidade à luz ambiente (exceto UV), não necessitar revelação química, apresentar baixo desvanecimento do sinal, ser de fácil análise e ter elevada resolução espacial [8].

\subsubsection{Dosimetria de irradiadores de sangue}

Comercialmente, já existem produtos voltados para a verificação da dose liberada no volume alvo em equipamentos autoblindados e, mais especificamente, aqueles que irradiam sangue. Dentre eles, os mais utilizados são o RadTag ${ }^{\circledR}$ (RadTag Technologies, Edmonton, Alberta, Canadá) e o RAD-SurE ${ }^{\circledR}$ (Ashland Inc., Covington, Kentucky, EUA), os quais são indicadores empregados nos bancos de sangue que utilizam radiação ionizante para a prevenção da DECH-AT. Ambos apresentam-se como etiquetas adesivas capazes de determinarem qualitativamente se certo limiar de dose absorvida foi adequadamente alcançado em cada bolsa de sangue. De fato, eles fornecem indicações visuais imediatas quando o mínimo de dose absorvida (15 ou 25 Gy, dependendo do modelo) foi entregue, bem como quando o máximo (50 
Gy) não foi ultrapassado. Certamente, tais produtos auxiliam bastante em termos de conformidade com aquilo que os principais órgãos reguladores recomendam.

O modo de funcionamento do $\operatorname{RadTag}^{\circledR}{ }^{\circledR}$ baseia-se em um círculo (porção sensível) presente no centro da etiqueta, que altera sua coloração de branca para azul ao ser exposto à radiação ionizante, correspondendo ao mínimo e ao máximo, Figura 1.5(a). Assim, a mudança de cor depende diretamente da dose absorvida pela etiqueta. De forma análoga, o RAD-SURE ${ }^{\circledR}$ apresenta uma tarja preta encobrindo a palavra NOT ("NÃO", em português), quando o mínimo de dose absorvida foi atingido, Figura 1.5(b).

Segundo as recomendações da $A A B B$, dispositivos radio-sensíveis devem ser empregados em cada irradiação, para demonstrar que uma dose adequada foi entregue em cada lote de hemocomponentes [13]. Embora bastante práticos, tais indicadores não são considerados dosímetros, uma vez que não são capazes de quantificar as doses por eles absorvidas, sendo, como o próprio nome diz, simples indicadores.

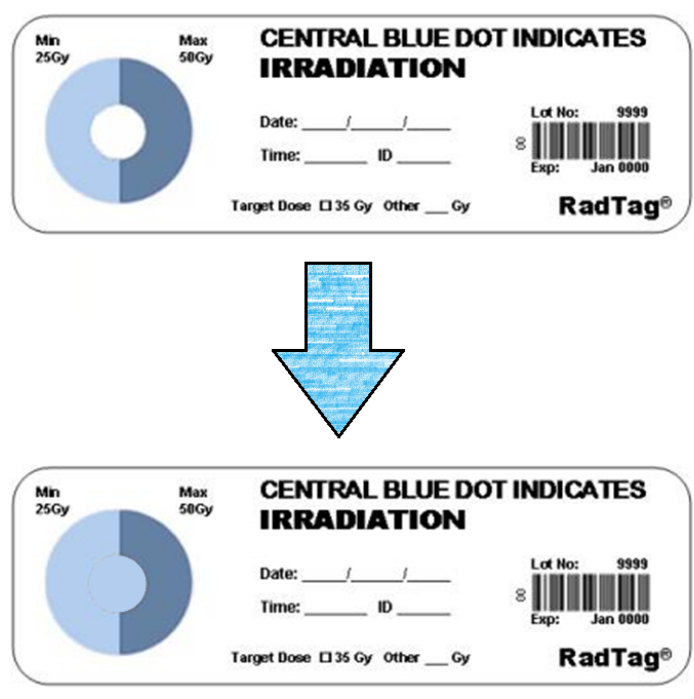

(a)

\begin{tabular}{|l|l|}
\hline ISP RAD-SURE & OPERATOR:__ DATE: \\
\hline 25 GY INDICATOR & IRRADIATED \\
\hline ISP TECHNOLOGIES INC. LOT NO:_ EXP: \\
\hline
\end{tabular}

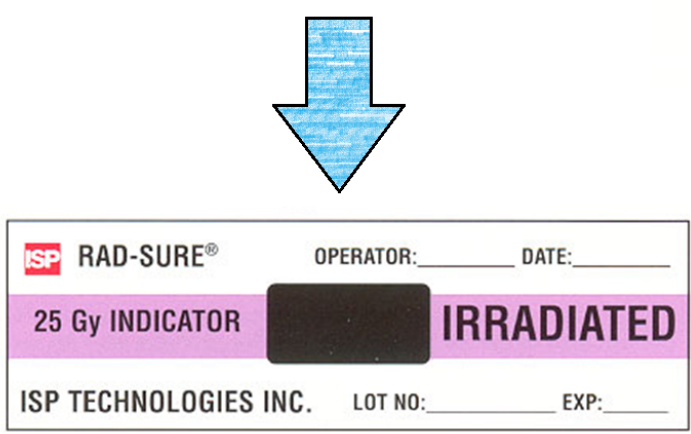

(b)

Figura 1.5. Ilustrações exibindo o comportamento dos indicadores RadTag ${ }^{\circledR}$ e RADSuRE ${ }^{\circledR}$ antes e após uma irradiação de 25 Gy. Imagens adaptadas dos respectivos sítios eletrônicos dos fabricantes.

Além desses indicadores, também existem sistemas comerciais voltados para a dosimetria de irradiadores de sangue, sendo o mais conhecido o DosE-MAP ${ }^{\text {TM }}$ (Ashland Inc., Covington, Kentucky, EUA), Figura 1.6. Esse sistema dosimétrico em- 
prega filme radiocrômico dentro de um cassete ${ }^{15}$ para mapear o volume irradiado. De acordo com o fabricante, a precisão do Dose-MAP ${ }^{\mathrm{TM}}$ é em torno de $\pm 5 \%$. Seu uso é baseado em sistema postal de dosimetria, isto é, o fabricante envia o cassete com o filme não irradiado juntamente com as instruções de uso, o cliente expõe o sistema no irradiador e retorna o filme irradiado para o fabricante, o qual realiza as medições dosimétricas e disponibiliza os resultados ao cliente.

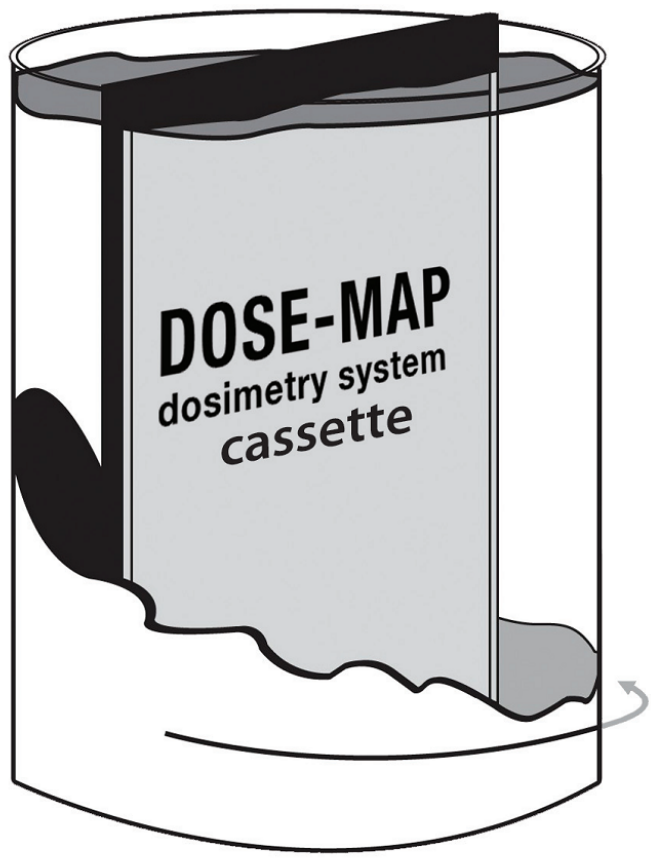

(a)

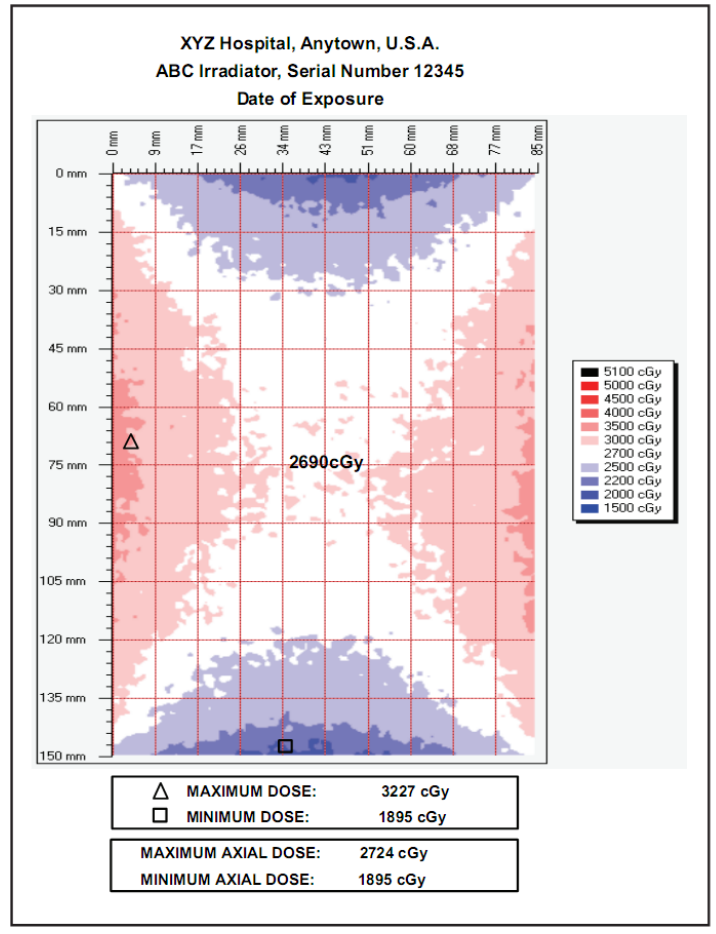

(b)

Figura 1.6. (a) Sistema dosimétrico DosE-MAP ${ }^{\mathrm{TM}}$ utilizado para dosimetria de irradiadores de sangue. (b) Distribuições espacial das doses absorvidas em irradiador específico de sangue. Imagens disponíveis no sítio eletrônico do fabricante.

\subsection{Simulação Monte Carlo}

\subsubsection{O código PENELOPE}

Apesar da simulação computacional não estar prevista originalmente neste trabalho e não ser o tema principal de estudo, essa ferramenta foi utilizada para comparações com os resultados obtidos experimentalmente. Dessa forma, uma breve

\footnotetext{
${ }^{15}$ Os cassetes ou chassis são dispositivos que protegem o filme contra a luz e fazem o contato entre este e a tela intensificadora.
} 
introdução é feita nesta seção sobre simulação Monte Carlo e, mais especificamente, sobre o código PENELOPE ${ }^{16}$. A maior parte deste texto que segue foi baseado no manual publicado por SALVAT et al [194].

O termo Monte Carlo foi atribuído nos anos de 1940 por cientistas que trabalhavam no projeto armamentista nuclear Los Alamos para designar uma classe de métodos numéricos baseado no uso de números randômicos. No final dos anos 1950, com a disponibilidade de computadores como ferramentas de trabalho, os métodos de simulação Monte Carlo desenvolveram-se como poderosas alternativas para lidar com os problemas de transporte de energia ionizante. Sabe-se que os fótons, elétrons e pósitrons de alta energia penetram na matéria sofrendo inúmeras interações, nas quais a energia é transferida aos átomos e moléculas do material, além da criação de partículas secundárias. A partir de repetidas interações com o meio, uma partícula de alta energia pode originar uma cascata de partículas, o que comumente é referido como shower (chuveiro, em inglês). Após cada interação, a energia da partícula é reduzida e outras partículas podem ser geradas, de modo que cada shower representa uma degradação efetiva da sua energia.

Basicamente, a evolução de um transporte de radiação (shower) é de natureza aleatória/randômica, de modo que é um processo passível para a simulação Monte Carlo. De fato, a característica mais peculiar do método Monte Carlo é a utilização de números e variáveis aleatórias, os quais são grandezas resultantes de processo repetitivos e seus valores efetivos não podem ser previstos com total certeza. Como consequência dessa metodologia de simulação, a principal ressalva sobre este método encontra-se em sua natureza aleatória: todos os resultados são governados por incertezas estatísticas, as quais podem ser reduzidas ao custo do aumento do conjunto amostral e, consequentemente, do tempo de computação.

Na simulação Monte Carlo de transporte de radiação, o trajeto (história) de uma partícula é visto como uma sequência aleatória de vôos livres que terminam com um evento onde a partícula muda a direção de seu movimento, perde energia e, ocasionalmente, produz partículas secundárias. Assim, as partículas interagem com os átomos e moléculas do meio a partir de vários mecanismos de competição,

\footnotetext{
${ }^{16}$ O PENELOPE é considerado um código livre, sendo distribuído gratuitamente pela Agência de Energia Nuclear (do inglês Nuclear Energy Agency, NEA).
} 
sendo cada mecanismo caracterizado por uma seção de choque diferencial ${ }^{17}$, que é função do estado das variáveis da partícula, sendo modificados durante o curso da interação. A simulação Monte Carlo de um dado arranjo experimental consiste na geração numérica de histórias aleatórias. Para gerar essas histórias, há a necessidade de um modelo de interação, isto é, um conjunto de seções de choque para os mecanismos mais relevantes. As seções de choque determinam a função de distribuição de probabilidade das variáveis aleatórias que caracterizam o trajeto. Uma vez que se conhecem essas funções de distribuição, histórias podem ser geradas usando métodos de amostragem aleatórios. Se o número de histórias é grande o suficiente, informações quantitativas sobre o processo de transporte podem ser obtidas pela média das histórias simuladas.

A versão do código Penelope ${ }^{18}$ empregada neste trabalho (versão 2008) é o resultado de uma evolução contínua desde a primeira versão, lançada em 1996, de maneira que, atualmente, é capaz de simular o transporte de elétrons, bem como de fótons com algumas centenas de $\mathrm{eV}$ até $\sim 1 \mathrm{GeV}$, para diversos materiais. Nesse intervalo de energia, os processos de interação são o efeito fotoelétrico, espalhamentos coerente (Rayleigh) e incoerente (Compton) e produção de pares (elétron-pósitron). O algoritmo baseia-se em um modelo de espalhamento que combina bancos de dados numéricos com modelos analíticos de seção de choque, para diferentes mecanismos de interação.

\footnotetext{
${ }^{17} \mathrm{~A}$ seção de choque diferencial representa a probabilidade, por unidade de ângulo sólido, de que uma dada partícula incidente seja espalhada em dado ângulo sólido.

${ }^{18}$ PenelOPe é o acrônimo de um código computacional que, inicialmente, simulava apenas interações de penetração e de perda de energia por pósitrons e elétrons
} 


\section{MATERIAIS E MÉTODOS}

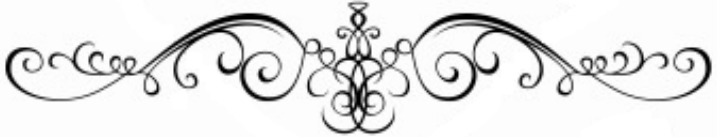




\section{Capítulo}

\section{MATERIAIS E MÉTODOS}

A finalidade desta tese é apresentar uma metodologia simples e rápida para a dosimetria da irradiação de sangue utilizando um dosímetro do tipo Fricke Xilenol Gel (FXG). Para tal, o FXG foi caracterizado e adaptado de maneira a cumprir as necessidades dessa dosimetria. Neste capítulo encontram-se os materiais utilizados durante os estudos, bem como a descrição das metodologias e técnicas das análises empregadas.

\subsection{Técnicas e equipamentos utilizados}

\subsubsection{Espectrofotometria}

Um cromóforo ${ }^{1}$ reflete a cor complementar que ele absorve, isto é, se um composto é amarelo, o material absorve a luz azul e, portanto, apresenta pico máximo de absorção na região azul do espectro. Assim, como o intervalo de linearidade do dosímetro FXG varia do laranja-avermelhado até o violeta, o comprimento de onda ideal para medidas de absorbância está situado aproximadamente entre o verde e o amarelo, Figura 2.1(a). Conforme pode ser visto no espectro do visível, ilustrado na Figura 2.2(b), as cores complementares correspondentes para essa variação encontram-se entre os comprimentos de onda de 530 e $600 \mathrm{~nm}$.

A partir dos dados preliminares obtidos por nosso grupo e outros da literatura, a banda centrada em $585 \mathrm{~nm}$ foi a escolhida para as análises das absorbâncias, já que esta é a que apresenta as maiores variações em função da dose absorvida pelo dosímetro FXG. Neste trabalho, uma das técnicas adotadas para inferir a dose

\footnotetext{
${ }^{1}$ Elemento responsável pela atribuição de cor a certo composto.
} 


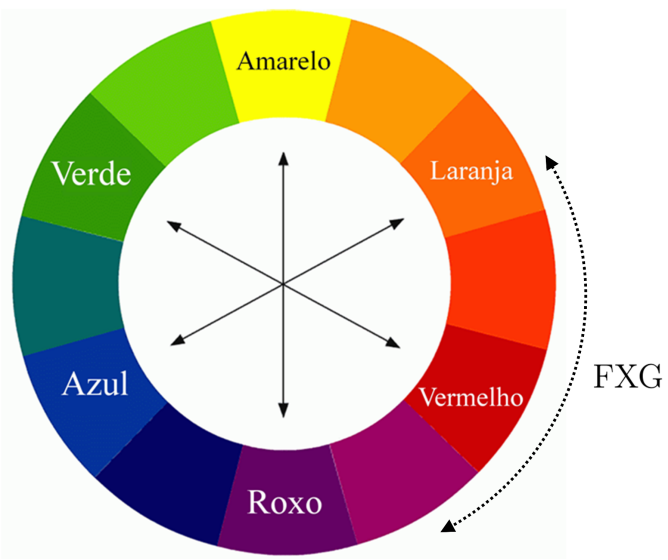

(a)

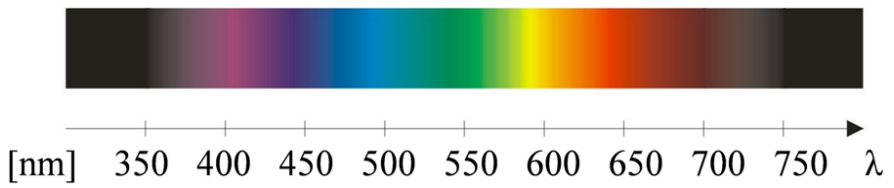

(b)

Figura 2.1. (a) Círculo cromático indicando as cores complementares. (b) Correspondências entre os comprimentos de ondas e as cores do espectro visível.

absorvida, $D$, no dosímetro FXG foi a de correlacionar esta grandeza com a variação de absorbância $\Delta \mathrm{A}$, da amostra irradiada, conforme a Equação (2.1).

$$
\Delta \mathrm{A}=\mathrm{A}(585 \mathrm{~nm})-\mathrm{A}_{0}(585 \mathrm{~nm})
$$

em que

$\Delta \mathrm{A} \quad$ : variação da absorbância,

A(585 nm) : absorbância da amostra irradiada em $585 \mathrm{~nm}$ e

$\mathrm{A}_{0}(585 \mathrm{~nm})$ : absorbância da amostra não irradiada em $585 \mathrm{~nm}$.

A determinação da variação da absorbância $\Delta \mathrm{A}$ foi realizado considerando-se as medidas obtidas de um espectrofotômetro (Ultrospec 6300/General Electric Co., Buckinghamshire, Inglaterra), disponível no Laboratório de Controle da Qualidade (LCQ) do Hemocentro de Ribeirão Preto. Como recomendação prática em termos de estabilidade eletrônica, o espectrofotômetro utilizado foi ligado por no mínimo 
20 minutos antes das auferições. Além do tempo de aquecimento, outro cuidado adotado foi o controle da temperatura ambiente, no qual o referido equipamento se situava, que fazia com que essa oscilasse entre $[20,5 ; 21,5] \pm 0,5{ }^{\circ} \mathrm{C}$. Este controle foi feito a fim de desprezar os fatores de correção na absorbância, conforme descritos no ICRU No. 35 [195].

Em medições espectrofotométricas há a necessidade de se adotar uma medida de referência, comumente conhecida como blank (do inglês, branco). Por definição, o blank é uma solução idêntica à amostra analisada, mas que não apresenta o soluto absorvedor de luz. Todavia nas medidas auferidas neste trabalho utilizou-se a água Milli-Q (Millipore, Massachusetts, EUA) como referência, que foi adotada a fim de se ter um critério de intercomparação "absoluto" para as soluções preparadas em diferentes dias. Ademais, tomou-se o cuidado de empregar sempre a mesma cubeta para comportar a água Milli-Q, quando das medidas do blank.

A luz de fundo ou luz espúria (stray light) em um espectrofotômetro é definida como aquela que se encontra fora da largura de banda do comprimento de onda selecionado. O efeito desta pode causar uma significativa diminuição na absorbância e consequente redução da faixa de linearidade do instrumento. Uma vez que medições que fornecem elevadas absorbâncias são mais fortemente influenciadas pela luz de fundo, procurou-se adequar o dosímetro FXG proposto para fornecer absorbâncias não maiores do que $2,5 \mathrm{~cm}^{-1}$.

\subsubsection{Sistema de aquisição digital de imagens}

A difusão dos íons férricos $\left(\mathrm{Fe}^{+3}\right)$ pela amostra pode representar uma limitação considerável dos dosímetros do tipo Fricke que se baseiam na detecção desses íons $[149,196]$. Isto torna-se particularmente significativo quando elevados gradientes de dose absorvida estão presentes e/ou quando certas metodologias de análise são empregadas, por exemplo, no caso da ressonância magnética em que os tempos tanto de preparo do equipamento, quanto o de aquisição dos dados não são negligenciáveis. Para esses casos, técnicas ópticas podem constituir uma metodologia de mensuração mais apropriada [143].

No sentido de remediar essa questão, um sistema de aquisição de imagens digital foi desenvolvido pelo grupo RADIARE a fim de adquirir dados quantitativos dos 
dosímetros radiocrômicos, isto é, do FXG e filme, por uma câmera do tipo $C C D$ e posteriormente permitir a construção de curvas de calibração e de isodoses. Tal sistema possui dimensões de $50 \times 50 \times 150 \mathrm{~cm}$ e, em sua base, existe uma fonte luminosa do tipo flash (Unitek, São Paulo, Brasil), a qual ilumina um anteparo difusor de luz (acrílico opaco de cor branca). A amostra foi acomodada no centro do anteparo do sistema, de modo a evitar possíveis gradientes de intensidade luminosa. No topo do sistema, a câmera registrava a intensidade de luz transmitida pela amostra, por meio de um sensor $C C D R G B$, com $23,7 \times 15,6 \mathrm{~mm}^{2}$ e $6,24 \times$ $10^{6}$ pixels (Nikon RGB sensor, Tóquio, Japão). As imagens foram salvas em formato .JPG, sem qualquer tipo de tratamento ou filtração pela câmera, considerando a velocidade de obturador e a abertura do diafragma fixos. Com o objetivo de diminuir a profundidade de campo (depth of field, DOF) procurou-se optar sempre por menores aberturas, isto é, grandes valores de paradas-f $(f$-stops $)$. Esse tipo de cuidado pode diminuir as aberrações ópticas e aumentar a resolução espacial e a sensibilidade do sistema, uma vez que, com menores aberturas, a quantidade de luz aceita pelas lentes é menor, o que aumenta a relação sinal/ruído. Assim, a abertura foi configurada em f/22 e a velocidade de disparo foi configurada em 1/100 s, a uma distância focal de $24 \mathrm{~mm}$, para manter o fotômetro da câmera próximo de zero.

A Figura 2.2 representa esquematicamente o sistema desenvolvido em nosso laboratório e utilizado durante as aquisições das imagens. Este é similar ao espectrofotômetro e antes de realizar as medidas foi previamente ligado por pelo menos 20 minutos para alcançar sua estabilidade. Para maiores informações sobre este específico sistema de aquisição pode ser encontrado na literatura [197].

Por meio de uma rotina escrita em MATLAB ${ }^{\circledR}$ (MathWorks 2010, Massachusetts, EUA), as análises das amostras de FXG e de filme foram realizadas a partir das imagens adquiridas antes e após as irradiações. Destas imagens, foram selecionadas as áreas de referência e de análise, nas quais as intensidades de cor no canal verde foram obtidas. Dessa maneira a Intensidade Relativa, R.I. $(i, j)$, foi calculada segundo a Equação (2.2). Estes foram processados através de um filtro bidimensional de médias adjacentes, seguido de outro do tipo Wiener [193,198]. Por fim, os dados foram normalizados em função do valor central e classificados em uma escala de cores do azul até o vermelho -, os quais são correspondentes a curvas percentuais de 50 


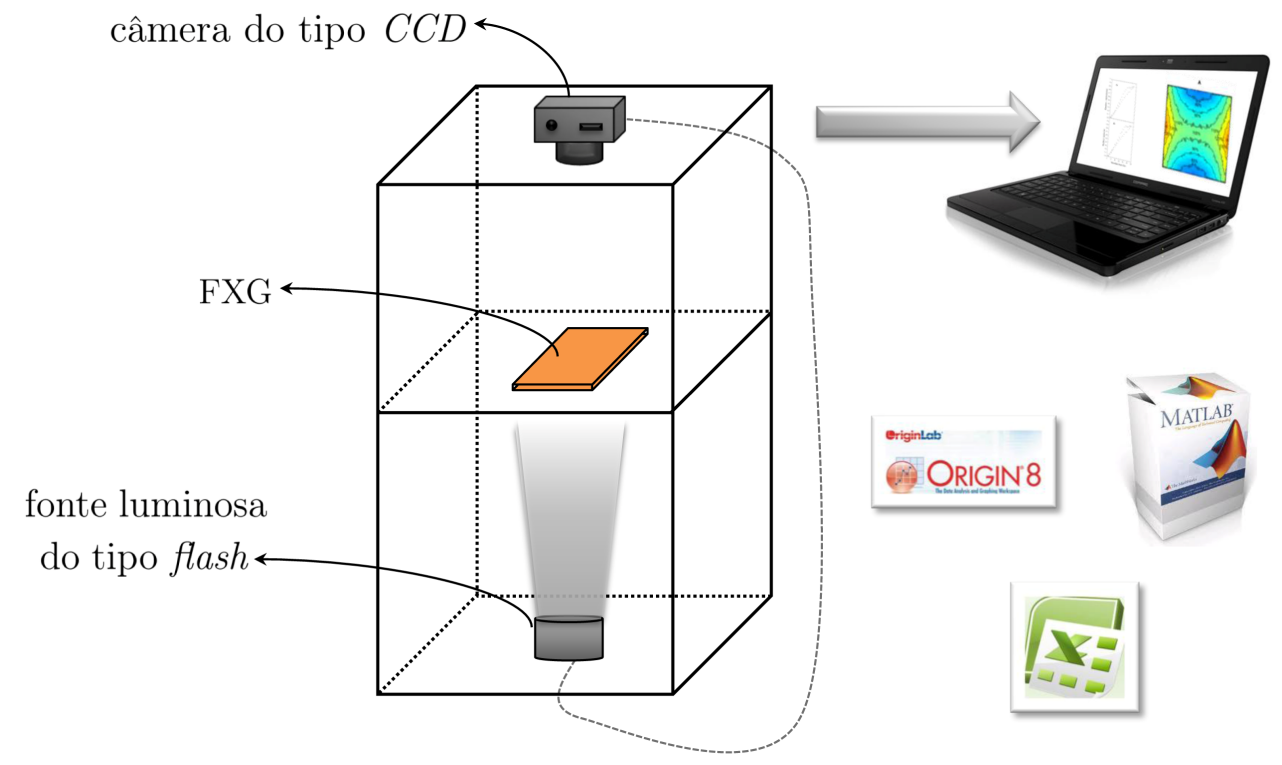

Figura 2.2. Esquema ilustrando o sistema de aquisição de imagens digitais utilizado para obtenção dos dados para os dosímetros FXG e filme.

até $150 \%$, respectivamente.

$$
R . I .(i, j)=\log \left[\frac{I_{0}(i, j) / I_{0 B}(i, j)}{I(i, j) / I_{B}(i, j)}\right]
$$

onde

R.I. $(i, j):$ intensidade relativa,

$I_{0}(i, j) \quad$ : intensidade da luz transmitida na linha $i$ e coluna $j$ para o dosímetro não irradiado,

$I_{0 B}(i, j)$ : intensidade da luz de fundo para a imagem do dosímetro não irradiado (background),

$I(i, j) \quad$ : intensidade da luz transmitida na linha $i$ e coluna $j$ para o dosímetro irradiado e

$I_{B}(i, j)$ : intensidade da luz de fundo para a imagem do dosímetro irradiado (background).

A resolução espacial de um dosímetro é um importante parâmetro para obtenção de suas respostas, embora dependa, também, do sistema de aquisição e técnica de 
análise. A resolução espacial do sistema dosimétrico ${ }^{2}$ foi estimada horizontal e verticalmente, por meio da função de transferência de modulação $(M T F)$, considerada a metodologia mais exata para se determinar o citado parâmetro. De maneira resumida, a quantificação da resolução espacial do sistema pode ser descrita da seguinte maneira:

(a) Primeiramente, obtém-se a imagem da superfície radiopaca sobre o FXG, na qual diferentes perfis são obtidos a partir de leituras perpendiculares às duas regiões, Figura 2.3. A interface entre essas duas regiões, que é conhecida como borda, produz um gradiente de intensidades, conforme mostra a Figura 2.4(a), a qual foi experimentalmente obtida pela média de 5 perfis. A superfície opaca corresponde à leituras mais baixas da função de distribuição de borda $(E S F)$, enquanto o FXG corresponde aos valores mais altos.

(b) Em segundo lugar, aplica-se a primeira derivada nesse perfil médio para obter a função de dispersão de linha $(L S F)$, Figura 2.4(b).

(c) Por fim, aplica-se a Transformada rápida de Fourier (FFT), obtendo-se a $M T F$, Figura 2.4(c). A partir do espectro normalizado de amplitude, a resolução espacial, em termos de frequência, é determinada escolhendo-se um limite para a $M T F$, tais como $10 \%, 5 \%$ ou $3 \%$, dependendo da finalidade do teste. Por motivos mais conservadores, escolheu-se o limite de $10 \%$.

Assim, seguindo-se os procedimentos acima e utilizando-se uma dose absorvida de 15 Gy e um campo de $20 \times 20 \mathrm{~cm}^{2}$, estimou-se a resolução espacial proporcionada pelo dosímetro FXG e o sistema dosimétrico.

\subsubsection{Programas de análise}

Como mencionado no início desta seção, uma rotina computacional foi elaborada em plataforma MATLAB ${ }^{\circledR}$ a fim de se analisarem os resultados das curvas de calibração obtidas com os dosímetros FXG e filme. Além da rapidez, a automatização do processo de análise reduz a probabilidade de erros por parte do operador, o que

\footnotetext{
${ }^{2}$ Nesta tese, consideram-se como sistemas dosimétricos os conjuntos "dosímetro + espectrofotômetro" e "dosímetro + sistema de aquisição de imagens $C C D$ ".
} 


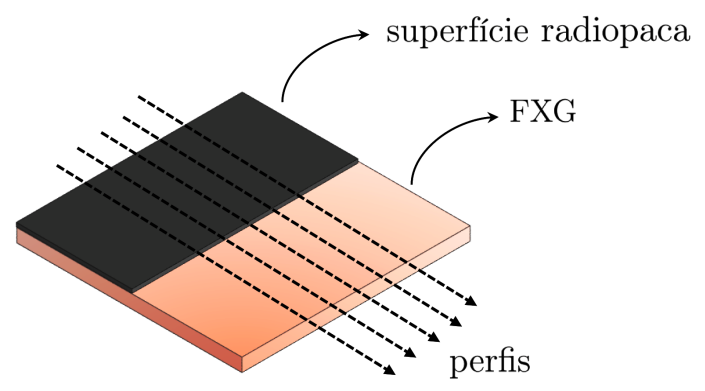

Figura 2.3. Esquema ilustrando a obtenção da função de distribuição de borda $(E S F)$ para o FXG calculando-se a média dos perfis de borda em uma cubeta de $1 \mathrm{~cm}$ de espessura.

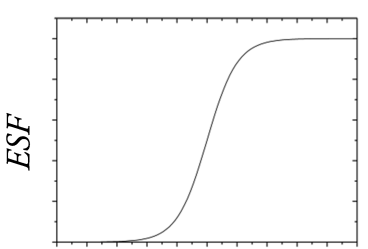

Distância

(a)

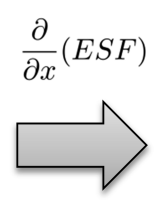

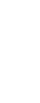


representa a fotografia da cubeta analisada e a da direita, o respectivo mapa de intensidade obtido com o canal escolhido (VERDE, LARANJA ou VERMELHO). Ao fim do processo de cálculo, o programa salva uma planilha de dados em formato '.txt' das medidas de densidade óptica, Equação (2.2), de cada amostra, seguida de sua respectiva incerteza propagada (arquivo "Intensidades.txt").

Para o caso das curvas de isodoses, o programa desenvolvido em MATLAB ${ }^{\circledR}$ foi em "linhas de comando" e, portanto, não possuía interface gráfica como a exibida acima. Na Figura 2.6 encontra-se o fluxograma representativo do algoritmo elaborado para a análise e construção das curvas de isodoses a partir dos dados obtidos com o sistema de aquisição digital para os dosímetros FXG e filme.

O algoritmo inicia com a selecão das imagens de referência (pré-irradiadas) e as de análise (pós-irradiadas). Em seguida, esses arquivos são lidos e armazenados em matrizes em um banco de dados. A "binarização" da imagem leva em conta a proporção de cores vermelho, verde e azul de cada dosímetro e elimina quaisquer regiões que estejam fora dessa proporção. Assim, com a "binarização" apenas o dosímetro fica evidenciado enquanto o restante da imagem ficava com intensidade nula. A "Seleção do canal" permite a escolha dos canais VERDE, LARANJA ou VERMELHO, de acordo com o dosímetro que estiver sendo analisado. A área de análise foi definida analogamente ao algoritmo de curvas de calibração (Figura 2.5). A correção para o brilho também considera uma região de background para a normalização da imagem. A seguir, as densidades ópticas são calculadas segundo a Equação (2.2) juntamente com as respectivas incertezas associadas a cada pixel $(i, j)$. Os ruídos são removidos considerando-se as menores variações que o $C C D$ consegue resolver. Filtros de média e Wiener bidimensionais foram utilizados a fim de suavizar os dados ${ }^{4}$.

A área de análise (área da cubeta) é, então, automaticamente selecionada baseando-se na resolução em dose absorvida que o sistema dosimétrico seja capaz de proporcionar. Por fim, as doses absorvidas são calculadas segundo os parâmetros fornecidos pelas curvas de calibração e normalizados pelo valor central. Os dados são dispostos em curvas de isodoses percentuais em uma escala de cores.

\footnotetext{
${ }^{4}$ A filtragem Wiener é uma técnica que permite o processamento de sinais a partir da separação de diferentes componentes, baseada em suas frequências espectrais, e é considerada uma técnica otimizada no sentido de que minimiza o erro médio quadrático no processo de filtragem e na suavização do ruído.
} 

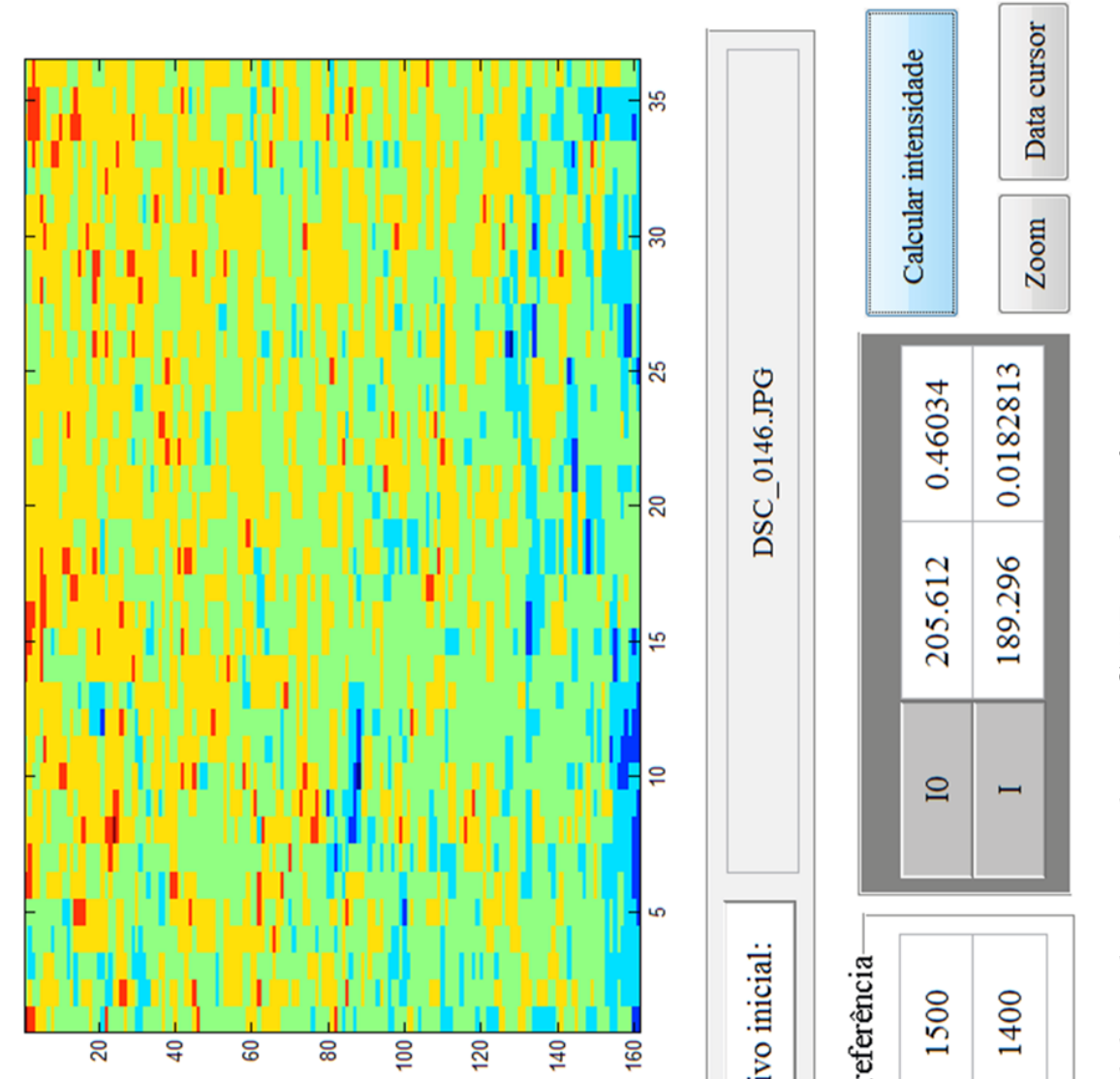

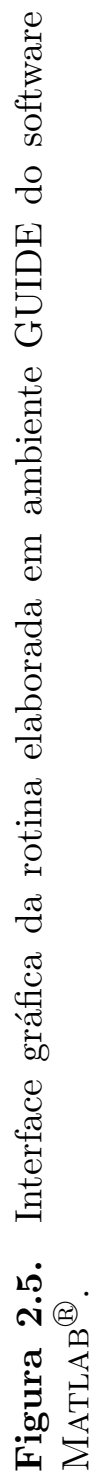
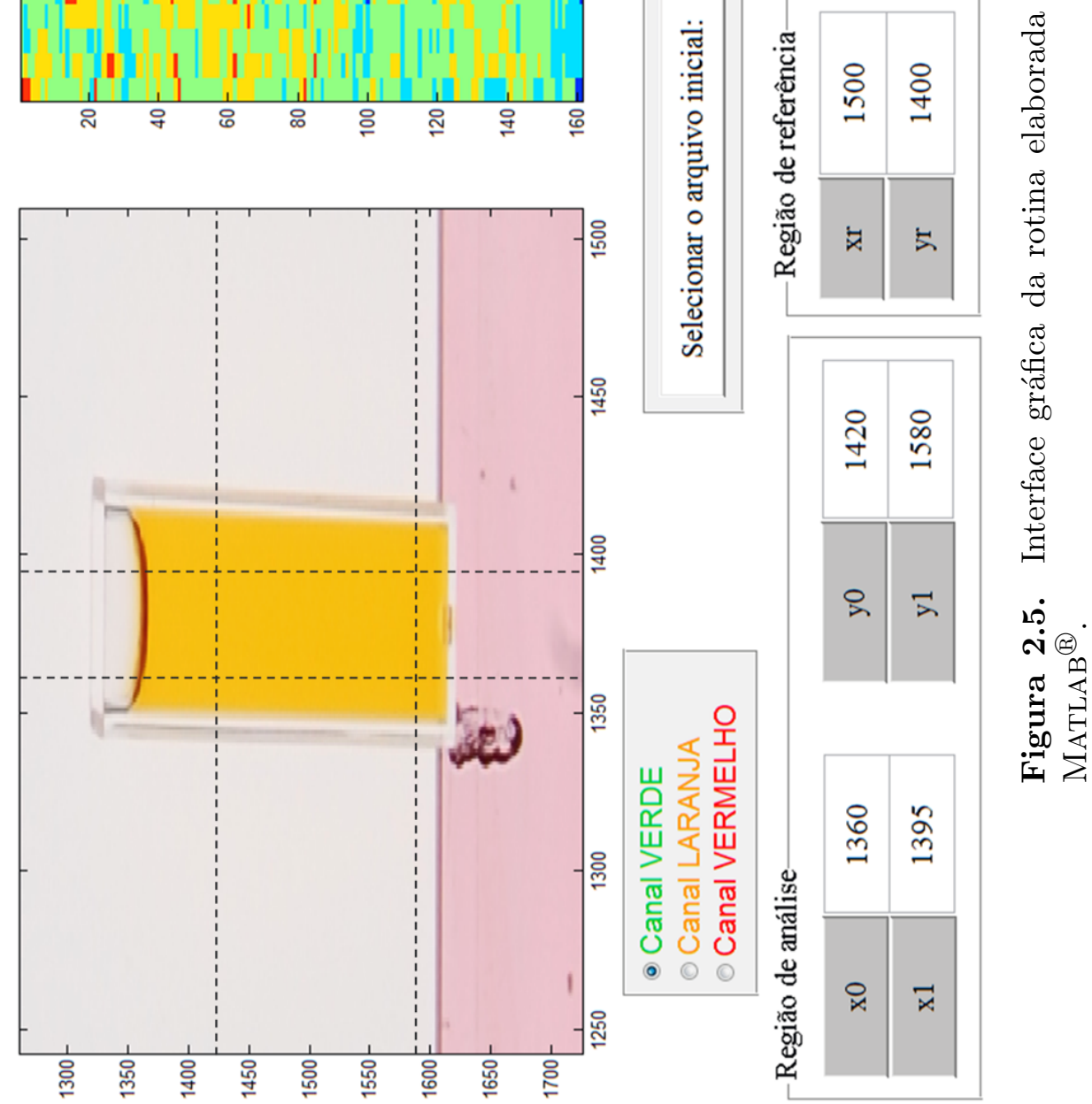


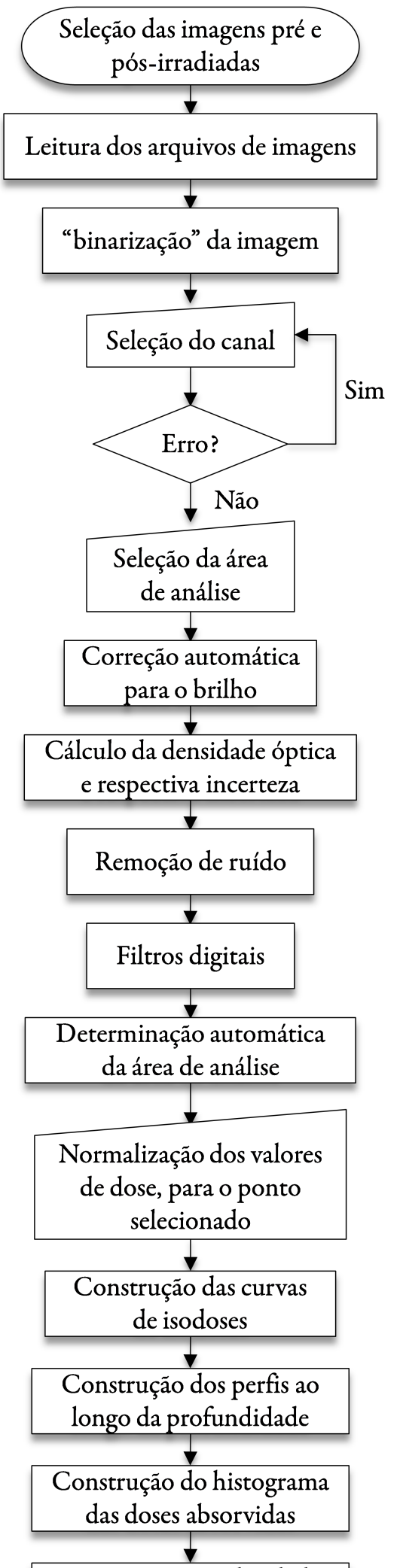

Armazenamento dos dados computados em arquivo .m

Fim

Figura 2.6. Fluxograma exibindo os principais processos da rotina escrita em MATLAB ${ }^{\circledR}$ para a dosimetria do irradiador específico. 


\subsubsection{Fontes de radiação e dosimetria de referência}

Neste trabalho, os materiais foram irradiados utilizando-se aparelhos de emissão de raios $\gamma$ (um equipamento de telecobaltoterapia e um irradiador de sangue autoblindado) e de raios X (acelerador linear $)^{5}$. Dentre as fontes radioativas, dois elementos foram empregados: o ${ }^{60} \mathrm{Co}$, de um Theratron $780 \mathrm{C}$ (Atomic Energy of Canada Limited, Ontario, Canadá) e o ${ }^{137} \mathrm{Cs}$, de um irradiador específico de sangue Gammacell ${ }^{\circledR} 3000$ Elan (Nordion International, Ontario, Canadá) ${ }^{6}$. Os raios X foram provenientes de um acelerador linear PRIMUS (Siemens, Alemanha) gerados com uma tensão de 6 MV. Foram utilizadas tanto as dependências do Hospital Beneficência Portuguesa de Ribeirão Preto, quanto do Hemocentro de Ribeirão Preto para a realização das referidas irradiações.

De acordo com a Norma CNEN $3.06^{7}$, os intrumentos de medida devem ser estabelecidos e implementados considerando programas de garantia da qualidade. Dentre os requisitos citados, especifica-se que aferições periódicas devem ser realizadas por instituições autorizadas pela Comissão Nacional de Energia Nuclear (CNEN) com fontes-teste nas faixas de energias em que os instrumentos são utilizados [201]. Muito embora a maioria dos equipamentos autoblindados que destinam-se a irradiar sangue empreguem o ${ }^{137} \mathrm{Cs}$, optou-se neste trabalho por caracterizar e adaptar o dosímetro FXG em feixes de um aparelho de telecobaltoterapia, em conformidade com a referida Norma. Além de atender à essa conformidade federal, a utilização desse aparelho levou em conta, também:

(a) a facilidade em termos de agendamento de experimentos,

(b) a deterioração do equipamento devido à faixa das doses absorvidas estudada,

(c) a facilidade de posicionamento e irradiação das amostras,

(d) a utilização de campos de radiação devidamente calibrados com câmara de ionização e

\footnotetext{
${ }^{5}$ Os equipamentos de teleterapia foram aferidos por câmaras de ionização calibrada em laboratório de padronização secundária - Instituto de Radioproteção e Dosimetria (IRD/CNEN), segundo protocolo usado na Radioterapia [199].

${ }^{6} \mathrm{~A}$ empresa Nordion International fornece os resultados da dosimetria de seus irradiadores baseado no dosímetro Fricke em forma de solução.

${ }^{7}$ A Norma CNEN 3.06 foi recentemente revogada pela Resolução CNEN No 130/12 [200].
} 
(e) as práticas nacionais de irradiação de sangue em equipamentos de cobaltoterapia.

Com relação ao primeiro quesito, a facilidade encontrava-se no fato de que a rotina clínica do ${ }^{60} \mathrm{Co}$, presente no Instituto Ribeirão-pretano de Combate ao Câncer Hospital Imaculada Conceição da Sociedade Portuguesa de Beneficência, encerravase no período vespertino, o que possibilitava a irradiação de amostras a partir desse horário. O segundo quesito está relacionado com o princípio físico de geração de radiação ionizante. Como o ${ }^{60} \mathrm{Co}$ é um radionuclídeo, apresenta uma dada atividade e não precisa de estímulos para emitir raios $\gamma$. Assim, em termos de deterioração do equipamento, isso é quase inexistente quando comparado com um acelerador linear $(L I N A C)$, por exemplo. Para o LINAC ocorre um desgaste considerável quando tem-se em vista os valores das doses absorvidas utilizados nos experimentos $[0 ; 54]$ Gy. O terceiro e quarto itens consideram os tamanhos dos campos proporcionados por um equipamento de teleterapia e as adequadas faixas de uniformidade dos campos. Por fim, o último fato considerado foi de que, embora a maior parte dos países desenvolvidos empregue irradiadores dedicados à irradiação de sangue, países emergentes (em desenvolvimento) ainda fazem uso de telecobaltos para essa finalidade, em razão dos elevados custos de um irradiador dedicado.

\subsection{Componentes e procedimentos de preparo do FXG}

Os seguintes componentes foram utilizados para o preparo do dosímetro FXG:

- gelatina de pele de porco 270 Bloom (Gelnex, Santa Catarina, Brasil),

- alaranjado de Xilenol, Xylenol Orange - XO (Merck, Darmstadt, Alemanha),

- ácido sulfúrico (J.T. Baker, New Jersey, EUA),

- sulfato ferroso amoniacal (Merck, Darmstadt, Alemanha) e

- água Milli-Q (Millipore, Massachusetts, EUA).

As massas ou volumes pertinentes a cada um dos componentes não serão dados nesta seção para facilidade de entendimento, sendo apresentados nas subseções seguintes. 
Informações adicionais, como os pesos moleculares, as concentrações e as porcentagens em massa de todos os componentes do FXG, podem ser encontradas na Tabela A.1

do Apêndice A.

Sabe-se que os procedimentos de preparo afetam consideravelmente a resposta do dosímetro FXG [153]. Dessa maneira, foram adotados os mesmos procedimentos em cada receita preparada, de acordo com as etapas abaixo.

(a) O primeiro passo é pesar todos os constituintes do dosímetro (gelatina, XO e $\mathrm{FeSO}_{4}$ ) em diferentes béqueres em balança analítica, Figura 2.7(a). Em seguida, separar a água Milli-Q em duas alíquotas: uma com $75 \%$ e outra com $25 \%$ do volume total, Figura 2.7(b).

(b) Na primeira alíquota, a gelatina deve ser adicionada e deixada por 15 minutos para dissolução, Figura 2.7(c).

(c) Após esse tempo, a solução acima deve ser aquecida até $45{ }^{\circ} \mathrm{C}$ com simultânea homogeneização por uma pulga magnética ${ }^{8}$.

(d) Atingidos $45^{\circ} \mathrm{C}$, a temperatura deve ser reajustada para $40{ }^{\circ} \mathrm{C}$. Com esta última temperatura e com a completa homogeneização da gelatina, os demais componentes do dosímetro devem ser adicionados, respeitando a seguinte ordem:

i. No béquer que contém a massa do alaranjado de Xilenol, devem ser adicionados: o volume de ácido sulfúrico, Figura 2.7(d), e aproximadamente $20 \%^{9}$ da segunda alíquota de água, para dissolução do $X O{ }^{10}$. A seguir, adicionar esta solução à de gelatina e água, Figura 2.7(e). O béquer que continha o $X O+$ ácido sulfúrico + água deve ser preenchido por mais 02 vezes com o mesmo volume de água, a fim de garantir que todo o $X O$ seja incorporado à solução (b).

\footnotetext{
${ }^{8}$ Embora estabeleça-se uma temperatura para a dissolução da gelatina, sabe-se que esta tem pouca influência na resposta do FXG para o intervalo de 35 até $60{ }^{\circ} \mathrm{C}$ [202].

${ }^{9}$ Para um volume de $100 \mathrm{ml}$ de $\mathrm{FXG}$, tal parte deve ser próximo de $5 \mathrm{ml}$.

${ }^{10}$ Nessa etapa deve-se tomar CUIDADO, pois ocorre uma reação exotérmica entre o ácido e a água. O uso de Equipamentos de Proteção Individual (EPI's) é recomendável; no caso, luvas, máscara e óculos de proteção.
} 
ii. O próximo passo consiste em acrescentar aproximadamente $20 \%$ de água Milli-Q da segunda alíquota no béquer que contém a massa do sulfato ferroso, sendo posteriormente adicionada à solução aquecida, Figura 2.7(f). Novamente, deve-se enxaguar por 02 vezes o béquer de modo que todo o composto seja adicionado à solução.

(e) Após homogeneização, deve-se preencher cubetas de acrílico comerciais ou de fabricação própria com a solução final, Figura 2.7(g).

(f) As cubetas devem ser acondicionadas no freezer ou geladeira (temperatura $<5$ ${ }^{\circ} \mathrm{C}$ ) até que a solução atinja a consistência de gel, Figura 2.7(h).

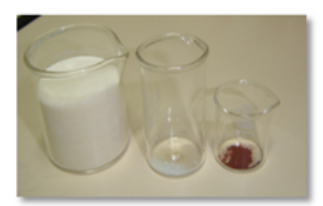

(a)

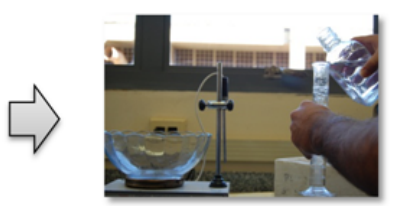

(b)

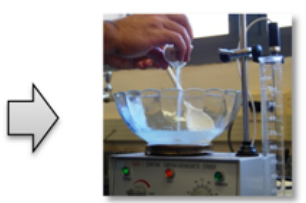

(c)

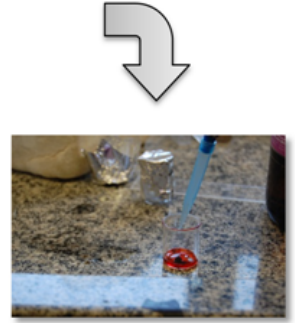

(d)

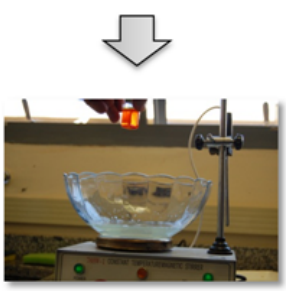

(h)

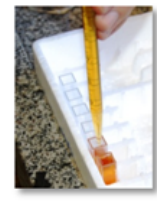

(g)

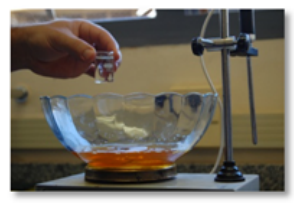

(f) (e)

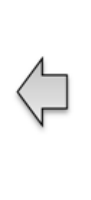

Figura 2.7. Fotos exibindo os procedimentos de preparo do dosímetro FXG.

\subsection{Caracterização do dosímetro FXG}

Muitos dos experimentos realizados para caracterizar a resposta do FXG foram baseados em curvas de calibração, isto é, em relações entre valores de medição conhecidos (fornecidos por padrões ou nominais) e as indicações correspondentes 
obtidas pelo sistema de medição, com suas respectivas incertezas associadas [203]. As condições gerais dos experimentos de caracterização e das análises foram:

- utilizar de 03 cubetas padrão de acrílico, 1,0 × 1,0 × 4,5 $\mathrm{cm}^{3}$, $\left(\right.$ Plastibrand $^{\mathrm{TM}}$, Sigma-Aldrich, EUA), sendo adotada a média das 03 leituras para indicação de cada dose absorvida,

- controlar as temperaturas ambiente $22,0 \pm 1,0{ }^{\circ} \mathrm{C}$ durante as irradiações e leituras das amostras,

- irradiar com feixe de fótons de ${ }^{60} \mathrm{Co}$, num campo $25 \times 25 \mathrm{~cm}^{2}$ e distância fonte-superfície de $(80,0 \pm 0,5) \mathrm{cm}$,

- irradiar as cubetas perpendicularmente à superfície,

- irradiar com passos de 3,00 \pm 0,09 Gy para o intervalo de [0,00; 54,00] Gy,

- utilizar acrílico como material de build-up ${ }^{11}$ e de retroespalhamento com espessuras dependentes do feixe utilizado,

- aguardar intervalo de 30 minutos entre a irradiação e leitura das amostras,

- estocar as amostras, entre o momento da irradiação e a leitura, com temperaturas de $\approx 5{ }^{\circ} \mathrm{C}$,

- realizar leituras de absorbância entre $[550 ; 600] \mathrm{nm}$, com velocidade de leitura de $2.500 \mathrm{~nm} / \mathrm{min}$.

Além dessas condições, tomou-se cuidado com os componentes ${ }^{12}$ empregados no preparo do dosímetro FXG, principalmente em relação à hidroafinidade que eles apresentam. Assim, todos os componentes foram mantidos em local seco, ao abrigo da luz e em temperaturas de $\approx 20,0 \pm 1,0{ }^{\circ} \mathrm{C}$.

Embora os espectros de absorbância dos dosímetros do tipo Fricke fossem anteriormente medidas de absorbância no UV [118,204], optou-se nesta tese pela faixa

\footnotetext{
${ }^{11} \mathrm{~A}$ região entre a superfície irradiada e a profundidade onde a dose absorvida atinge o valor máximo é chamada de região de build-up (crescimento, em português), sendo também conhecida como região de equilíbrio eletrônico. A partir desse ponto, a dose absorvida decresce exponencialmente pela atenuação do material, considerando-se um feixe estreito de radiação.

${ }^{12}$ Os componentes utilizados no preparo do FXG encontram-se no Apêndice A.
} 
do visível devido à praticidade durante a aquisição dos dados e à sensibilidade do FXG. Como há necessidade de se utilizarem cubetas de quartzo para a aquisição de dados na região UV e tem-se por objetivo nesta tese propor uma dosimetria de baixo custo e simples, optou-se por utilizar cubetas de acrílico. Apesar de suas aplicações serem limitadas à comprimentos de onda visíveis, cubetas de acrílico são até duas ordens de grandeza mais em conta. Além disso, o coeficiente de extinção molar, que é um reflexo da sensibilidade dos dosímetros do tipo Fricke, é quase uma ordem de grandeza superior para a região espectral do verde [148], quando comparado ao UV.

\subsubsection{Linearidade, sensibilidade, desvanecimento e repe- titividade}

A faixa de linearidade para o FXG foi avaliada considerando-se diferentes concentrações de cada componente do dosímetro e em todo o intervalo de doses absorvidas utilizado na Hemoterapia [15; 50] Gy. A linearidade foi analisada considerando-se o coeficiente de correlação linear $(r)$ e o Erro Padrão de Previsão (Standard Error of Prediction - SEP), que serão abordados nas subseções seguintes.

Por definição, sensibilidade é o quociente entre a variação de uma determinada indicação de um sistema de medição e a variação correspondente do valor da grandeza medida [203]. Assim, adotou-se como medida de sensibilidade o coeficiente angular das curvas de calibração que relacionavam a variação da Absorbância $(\Delta \mathrm{A})$ com a Dose absorvida $(D)$ [205], calculada de acordo com o método dos mínimos quadrados.

Também foram coletadas medidas de desvanecimento da resposta para os dosímetros estudados em função do tempo. Para tanto, as amostras foram armazenados em condições consideradas mais críticas do que as ideiais, mas que não induzissem o derretimento do gel. Essas condições foram: 1) temperatura controlada de 21,0 $\pm 1,0{ }^{\circ} \mathrm{C}$ e 2) exposição à luz visível proveniente de lâmpadas fluorescentes. Dessa maneira, as amostras foram irradiadas de acordo com as condições gerais dos experimentos de caracterização (vide página 48) e lidas 1, 2, 3 e 4 hr(s) após a primeira medição.

A precisão ${ }^{13}$ de cada medição foi determinada conforme um conjunto de con-

\footnotetext{
${ }^{13}$ Grau de concordância entre indicações ou valores medidos, obtidos por medições repetidas, no mesmo objeto ou em objetos similares, sob condições de repetitividade, de precisão intermediária ou de reprodutibilidade.
} 
dições de repetitividade, isto é, conforme um conjunto de condições, nas quais o mesmo procedimento de medição, o mesmo operador, o mesmo sistema de medição, as mesmas condições de operação e o mesmo local, assim como medições repetidas no mesmo objeto ou em objetos similares foram adotados durante um curto período de tempo [203]. Dessa forma, os dosímetros foram avaliados considerando-se a média de 06 leituras por Dose absorvida, de acordo com as condições gerais estabelecidas anteriormente. O desvio-padrão percentual foi adotado como grandeza representativa da repetitivadade do conjunto amostral.

Nas subseções que seguem, as diferentes condições experimentais encontram-se descritas para a caracterização do FXG.

\subsubsection{Influência do oxigênio}

Como os dosímetros do tipo Fricke baseiam-se na oxidação dos íon ferrosos para a inferência da dose absorvida, a presença de oxigênio na solução é crucial para uma adequada resposta. Dessa maneira, o primeiro parâmetro avaliado foi a influência do ar durante o preparo das amostras, o que foi realizado aumentando-se a velocidade de rotação da pulga magnética até o surgimento de bolhas na solução [118].

\subsubsection{Influência do sulfato ferroso amoniacal}

Conforme mencionado no Capítulo 1, seção 1.2.1, o sulfato ferroso é o composto responsável pelo princípio dosimétrico do FXG. Nesse sentido, procurou-se estudar de que maneira alterações em sua concentração possibilitariam mudanças no intervalo de trabalho do dosímetro. Assim, tendo-se em vista que o FXG saturase em torno de $40 \mathrm{~Gy}^{14}$, uma primeira abordagem procurou eliminar tal saturação aumentando-se a concentração de $\mathrm{Fe}^{+2}$. A partir dessa premissa, diferentes receitas de FXG foram testadas, segundo as condições gerais, no que tange à variação da concentração de sulfato ferroso amoniacal ${ }^{15},\left[\mathrm{FeSO}_{4}\right]$. As concentrações molares empregadas foram: 0,32; 0,63 (original); 1,$26 ; 2,52$ e 5,04 $\pm 0,03 \mathrm{mM}$. Tais concentrações foram arbitariamente escolhidas. Com isso visou-se analisar tanto a

\footnotetext{
${ }^{14}$ Lembrando-se que esse limite de dose absorvida é válido para medidas de absorbância e que depende fortemente dos componentes utilizados durante o preparo do dosímetro.

${ }^{15}$ Por questões de simplicidade na escrita e uniformização da terminologia, o sulfato ferroso amoniacal será referido nos textos que seguem apenas por $\mathrm{FeSO}_{4}$.
} 
linearidade quanto a sensibilidade da resposta do dosímetro estudado, a partir de cada curva de calibração.

\subsubsection{Influência da gelatina}

A gelatina tem como função básica manter a integridade espacial da dose absorvida em uma amostra irradiada. Embora existam outras matrizes para tal finalidade, a gelatina de pele de porco tem a propriedade de ser um material tecido equivalente. Além disso, ela tem um ponto de derretimento bastante razoável $\left(\approx 45^{\circ} \mathrm{C}\right)$, o que torna-se vantajoso, pois diminui-se a probabilidade de perda do oxigênio dissolvido na solução pelo calor e é opticamente transparente, o que a torna ideal para medições espectrofotométricas. Por ser uma cadeia polipeptídica, a gelatina também promove o aumento do rendimento químico dos íons férricos pela oxidação radioinduzida. Dessa maneira, optou-se em estudar a variação da concentração desse componente a fim de avaliar sua influência tanto na linearidade quanto nos valores de absorbância obtidos para doses absorvidas maiores do que 40 Gy.

Para tanto, diferentes receitas do dosímetro FXG foram testadas, segundo as condições gerais, no que tange à concentração da gelatina de pele de porco 270 Bloom, $\left[\mathrm{C}_{17} \mathrm{H}_{32} \mathrm{~N}_{5} \mathrm{O}_{6}\right]$. As concentrações molares estudadas foram: 0,00; 31,10; 62,$19 ; 124,38$ (original) e 248,75 \pm 0,62 mM. A gelatina 270 Bloom, além de apresentar um custo mais razoável no mercado nacional, foi a gelatina escolhida devido à adequada performance em medidas dosimétricas quando comparadas com aquelas apresentadas pela 300 Bloom [206].

\subsubsection{Influência do ácido sulfúrico}

Como mencionado no Capítulo 1, o Xilenol apresenta um intervalo ótimo de pH para seu uso, o que evita agregação imediata entre esse sal e íons férricos naturalmente oxidados na solução. Levando-se em consideração as condições gerais, sua concentração, $\left[\mathrm{H}_{2} \mathrm{SO}_{4}\right]$, foi investigada para: 12,19; 24,39 (original); 48,78; 73,17; 97,44 e $121,95 \pm 0,07 \mathrm{mM}$.

\subsubsection{Influência do alaranjado de Xilenol}

O alaranjado de Xilenol tem a função de deslocar as mudanças químicas decorrentes da irradiação para a faixa do visível, o que ocorre devido à ligação desse sal 
com os íons férricos $\mathrm{Fe}^{+3}$. Isso permite que um maior número de técnicas ópticas sejam aplicadas, tal como a baseada em sensor $C C D$, sugerida nesta tese. Devido à sua importância na receita do FXG, a concentração do $\mathrm{XO},\left[\mathrm{C}_{31} \mathrm{H}_{28} \mathrm{~N}_{2} \mathrm{O}_{13}\right]$, foi avaliada para os seguintes casos: 0,050; 0,100 (original); 0,110; 125; 0,200 e 0,250 \pm 0,008 mM, considerando-se novamente as condições gerais de experimento.

\subsubsection{Influência do cloreto de sódio}

O rendimento químico $G\left(F^{+3}\right)$ pode ser aumentado devido a componentes orgânicos, tais como a gelatina $[124,142]$. Para a dosimetria, esse tipo de aumento nem sempre é desejável, uma vez que na maioria das ocasiões ele é totalmente aleatório e resultante de impurezas presentes nos componentes do FXG. Tal influência pode ser remediada pela adição de cloreto de sódio $(\mathrm{NaCl})$ no preparo do dosímetro [142]. Dessa maneira, a influência de $\mathrm{NaCl}$ (Sigma-Aldrich, Missouri, EUA) foi investigada em três concentrações: 0,32; 0,63 e 1,26 \pm 0,05 mM, considerando-se as condições gerais .

\subsubsection{Dependência com a temperatura durante a irradia- ção do FXG}

Sangue e seus componentes são normalmente refrigerados ou congelados como parte do processo de preservação das células a serem transfundidas. Assim, cuidados devem ser tomados para garantir que tanto os dosímetros a serem empregados quanto os indicadores radio-sensíveis presentes nas bolsas de sangue $\left(\operatorname{RadTag}^{\circledR}\right.$ e RAD-SurE ${ }^{\circledR}$ ) possam ser utilizados sob essas condições. A fim de verificar as propriedades do FXG sob essas circunstâncias, curvas de calibração foram estabelecidas considerando-se as condições gerais em duas temperaturas distintas: 3,0 e 23,0 \pm 1,0 ${ }^{\circ} \mathrm{C}$. Tais temperaturas dos dosímetros foram conseguidas a partir de uma cuba de água com temperaturas controladas. Nessas irradiações, as amostras de FXG foram embrulhadas em filme do tipo PVC [207] a fim de evitar o contato entre os meios e possível oxidação/contaminação.

\subsubsection{Dependência com a taxa de dose e energia}

Embora seja desejável que sangue e hemocomponentes sejam irradiados em equipamentos específicos devido ao menor tempo de irradiação, no Brasil essa realidade 
ainda está longe de se tornar um padrão. Visto que muitas dessas irradiações ocorrem em equipamentos de teleterapia, duas qualidades do feixe foram estudadas a fim de verificar a dependência de resposta do dosímetro FXG. A primeira foi a taxa de dose, a qual variou de 0,48 até 2,30 $\pm 0,16 \mathrm{~Gy} / \mathrm{min}$ em feixe de ${ }^{60} \mathrm{Co}$. A segunda, foi a energia, em que feixes de raios X de $6 \mathrm{MV}$ foram empregados, além dos raios $\gamma$ dos equipamentos contendo ${ }^{60} \mathrm{Co}$.

\subsubsection{Resolução de resposta do FXG em dose absorvida}

A resolução da resposta em dose absorvida, isto é, a menor variação da dose absorvida que causava uma variação perceptível na absorbância correspondente, foi avaliada considerando-se as condições gerais dispostas anteriormente, em que valores de até $0,10 \pm 0,03$ Gy foram entregues entre duas exposições distintas para dada curva de calibração.

\subsubsection{Efeitos devido ao armazenamento do FXG}

Esta tese tem como objetivo propor um dosímetro voltado para a irradiação de sangue e que seja capaz de ser empregado em uma rotina diária de qualquer centro de Hemoterapia. Nesse sentido, a resposta do dosímetro FXG também foi avaliada com relação ao tempo de validade seguindo as condições gerais , isto é, a resposta do FXG foi avaliada com relação ao tempo que o dosímetro não irradiado fora armazenado. Para tanto, o dosímetro FXG foi preparado 5, 24, 48, 72 e $96 \pm$ 2 horas antes de ser exposto à radiação ionizante, de modo a avaliar a dependência do desvanecimento, da sensibilidade e da saturação com o tempo de estocagem.

\subsection{Dosimetria do irradiador de sangue}

O mapeamento da dose absorvida tem por finalidade determinar tanto o valor quanto a localização das doses máxima e mínima que dada irradiação pode resultar. Para o irradiador específico de sangue empregado nesta tese, as bolsas de sangue ficam muito próximas das fontes radioativas $(\approx 0,6 \mathrm{~cm})$, ocasionando gradientes consideráveis na periferia do volume irradiado.

Um objeto simulador (OS) foi especificamente desenvolvido para a realização da dosimetria do irradiador de sangue. Neste OS, o dosímetro FXG foi inserido 
em uma cubeta constituída de acrílico (PMMA) com dimensões de 12,4 × 19,4 cm. Ao redor dessa cubeta, duas outras semicilíndricas, também de PMMA, foram preenchidas com água, Figura 2.8. As paredes de PMMA possuíam espessura em torno de 2,0 mm devido à questões de build-up para o ${ }^{137} \mathrm{Cs}$ [208]. A geometria do OS foi escolhida de maneira a adequar-se ao vasilhame do irradiador e que, simultaneamente, permitisse a aquisição das distribuições da dose absorvida no plano central do volume irradiado, por meio do sistema de aquisição de imagens $C C D$.
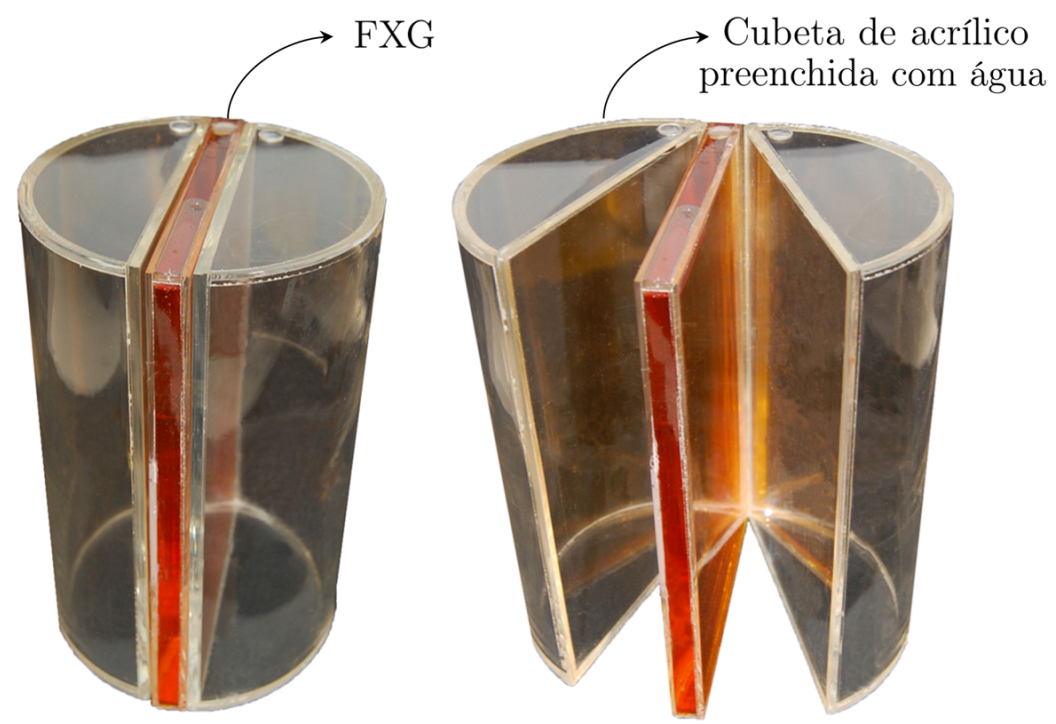

Figura 2.8. Objeto simulador utilizado durante a dosimetria do irradiador de sangue, composto de uma cubeta de acrílico preenchida com FXG e duas cubetas, também de acrílico, preenchidas com água.

\subsubsection{Caracterização dos objetos simuladores de sangue}

Desde meados de 1900, inúmeros líquidos e sólidos já foram utilizados como substitutos em experimentos que investigavam os efeitos da radiação ionizante sobre o tecido humano. De acordo com a definição do ICRU No. 46 [209], esses materiais, ditos objetos simuladores ou phantoms, são objetos físicos ou virtuais empregados para avaliar a interação da radiação com o tecido e gerar estimativas da qualidade de imagens médicas. Uma extensa revisão dos principais materiais e sistemas utilizados como objetos simuladores em feixes de fótons e elétrons foi feita por WHITE et al [210]. Embora essa revisão tenha sido realizada há mais de 30 anos, muitos dos materiais revisados ainda são empregados na dosimetria ou servem como base para sistemas mais recentemente desenvolvidos. 
A fim de ser aceito como um substituto, o material simulador deve idealmente interagir com a radiação ionizante, tanto em termos de absorção quanto de espalhamento, de forma semelhante ao material que se queira substituir. Os critérios de aceitação incluem comparações entre os coeficientes de atenuação e de absorção mássicos $\left(\mu / \rho\right.$ e $\left.\mu_{e n} / \rho\right)$ para fótons e os stopping power's mássicos ${ }^{16}(S)$ para elétrons, os quais são fortemente dependentes do número atômico efetivo $\left(Z_{e f f}\right)$ e da densidade eletrônica do material $\left(\rho_{e}\right)$ [125].

Os materiais mais comumentes utilizados e recomendados para simular as interações da radiação ionizante com sangue e tecidos moles em geral são: o acrílico ${ }^{17}$, a água e o poliestireno [4-6,92,95,118,120,125,199,211,212,212-214]. Os dois primeiros materiais já são extensamente conhecidos na literatura e amplamente aplicados em rotinas de radioterapia. O poliestireno também é comumente utilizado como objeto simulador de sangue ao se realizarem testes dosimétricos [4-6, 92, 95, 212, 213], em especial quando se utiliza fonte de ${ }^{137} \mathrm{Cs}$ [214].

Considerando o exposto acima, tanto os dosímetros FXG, filme e TL's, quanto os objetos simuladores de acrílico, água e poliestireno, foram caracterizados em termos de $\mu / \rho$ e $S$, considerando os dados disponíveis no sítio eletrônico do Instituto NorteAmericano de Padrões e Tecnologia (National Institute of Standards and Technology - NIST) [215].

\subsubsection{Dosimetria de referência}

Uma vez que não é possível a utilização de câmaras de ionização ou diodos em um irradiador específico de sangue, metodologias alternativas foram empregadas para a dosimetria. A realização da dosimetria de referência do irradiador Gammacell utilizou dosímetros TL's (LiF-100, Harshaw Chemical Co., Ohio, EUA) e filme radiocrômico EBT2 (GAFChromic ${ }^{\mathrm{TM}}$, International Specialty Products, New Jersey, EUA).

A dosimetria por meio do filme radiocrômico deu-se de forma análoga. Contudo, o OS utilizado foi o mesmo que o da dosimetria FXG, representado na Figura 2.8, em que a cubeta central fora substituída por um pedaço de filme EBT2 "san-

\footnotetext{
${ }^{16}$ Poder de freamento, em inglês. Tal grandeza representa o valor esperado do gradiente de perda de energia cinética por unidade de comprimento percorrida por uma partícula carregada num meio.

${ }^{17}$ Comercialmente, também é conhecido como Plexiglas, Lucite e Perspex.
} 
duichado"por várias placas de acrílico. Como cada uma dessas placas de acrílico possuía espessura de 0,1 mm, foram utilizadas 11 placas a fim de preencher todo o espaço entre as cubetas semicilíndricas. Após irradiados, os filmes foram lidos pelo sistema de aquisição $C C D$.

\subsubsection{Dosimetria Termoluminescente, TLD}

Os dosímetros termoluminescentes constituídos de fluoreto de lítio foram dispostos em cristais numerados com dimensões médias de $2,0 \times 2,0 \times 1,0 \mathrm{~mm}$. Antes de cada irradiação, os cristais foram tratados termicamente (annealing) em um forno préaquecido por 01 hora a $380,0 \pm 5,0{ }^{\circ} \mathrm{C}$. Após esse procedimento, os TL's foram deixados por mais 02 horas a $100,0 \pm 5,0^{\circ} \mathrm{C}$ e, a seguir, resfriados a temperatura ambiente, conforme o manual do fabricante recomenda. Os dosímetros foram, então, irradiados após períodos não maiores do que 24 horas.

A calibração dos dosímetros foi realizada em campos de radiação com características dosimétricas bem conhecidas. Para isso, utilizou-se a fonte de ${ }^{60}$ Co. Após as irradiações, os TL's sofreram tratamento térmico por $15 \pm 1$ min a $100,0 \pm 5,0{ }^{\circ} \mathrm{C}$ e resfriados a temperatura ambiente por $20 \pm 1 \mathrm{~min}$, com a finalidade de eliminar sinais espúrios [216].

As irradiações dos dosímetros TL's para a aquisição da dosimetria de referência do irradiador foram realizadas em um OS cilíndrico de poliestireno ${ }^{18}$, Figura 2.9(a). Ao todo, 32 placas de 6,04 $\pm 0,04 \mathrm{~mm}$ de espessura e 12,27 $\pm 0,04 \mathrm{~cm}$ de diâmetro médios compunham o OS, sendo que 09 delas possuíam orifícios ao longo de seu diâmetro (placa tipo A) e outras 06 possuíam apenas orifícios centrais (placa tipo B), conforme esquematizado na Figura 2.9(b). Em todas as placas foram inseridos 02 dosímetros TL's por orifício. Com o OS preenchido pelos TL's, este foi colocado no vasilhame do irradiador específico e irradiado por 1,00 $\pm 0,01 \mathrm{~min}$, a uma taxa de rotação de aproximadamente 30 r.p.m. Por questões de simetria, apenas metade dos orifícios das placas do tipo A foram preenchidos [4].

As leituras de cada cristal TL foram realizadas por meio de uma série de instrumentos interconectados. Primeiramente, um sistema de aquecimento Harshaw Thermoluminescence Detector 2000C (Harshaw/Nuclear Systems, EUA) aquecia linear

\footnotetext{
${ }^{18}$ Embora o TRS 398 [199] recomende água como objeto simulador de meio, outros materiais, sobretudo plásticos, são aceitáveis para tal finalidade $[6,211]$.
} 


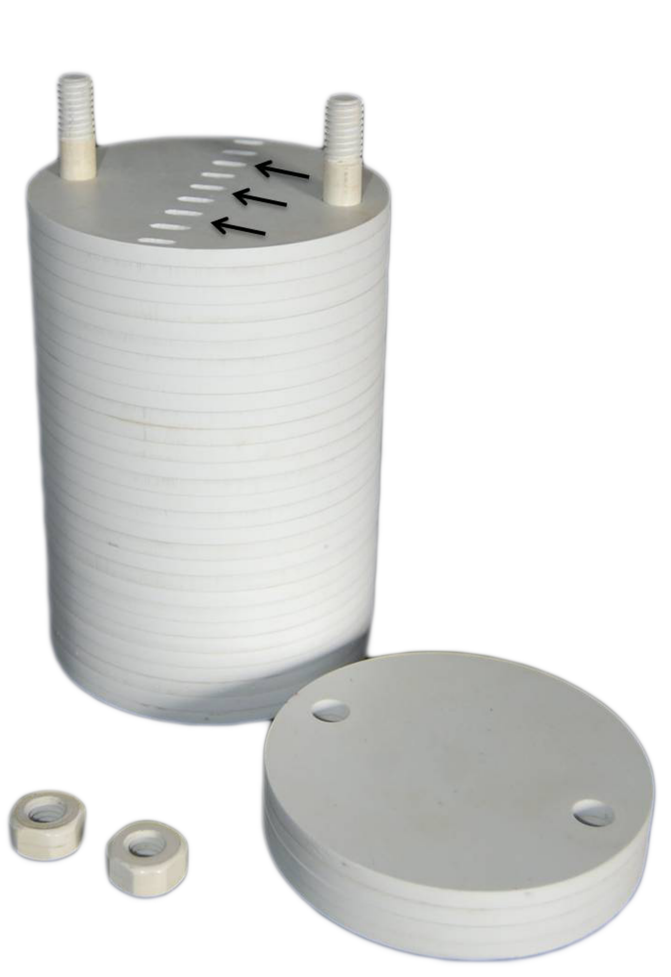

(a)

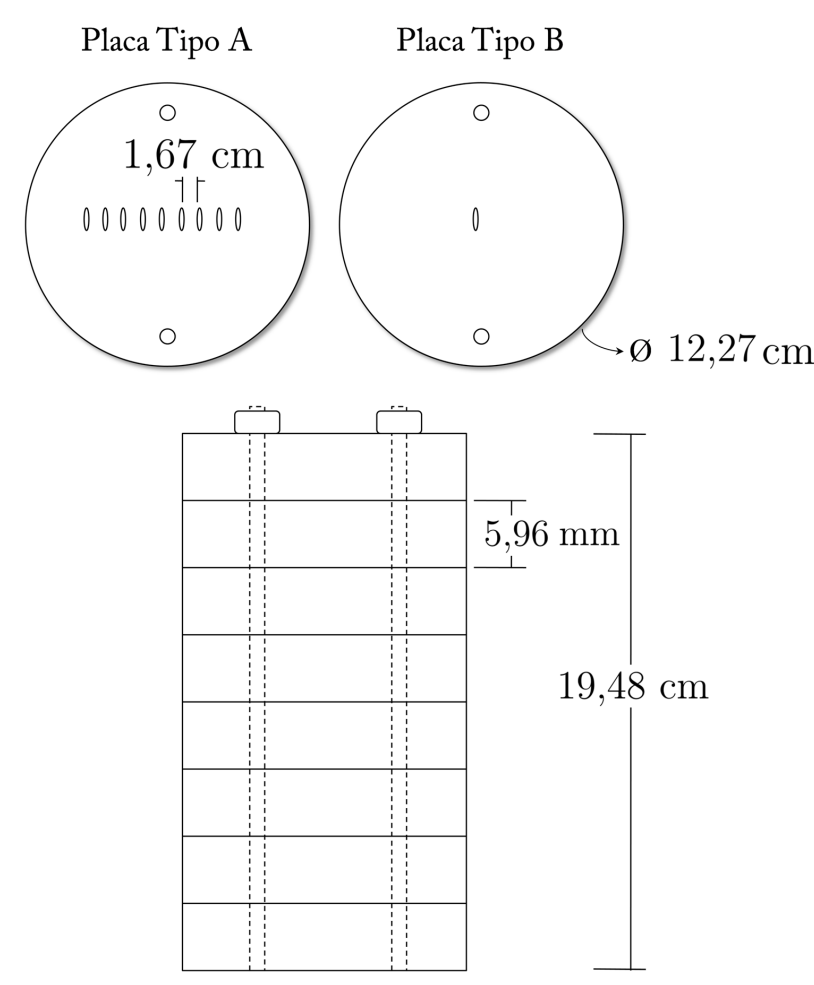

(b)

Figura 2.9. (a) Objeto simulador de poliestireno utilizado para a obtenção das medidas no irradiador de sangue. (b) Esquema exibindo as placas tipo A e B do OS de poliestireno.

e continuamente os dosímetros irradiados de 90,0 até $250,0 \pm 0,5{ }^{\circ} \mathrm{C}$. Esse sistema de aquecimento possui uma fotomultiplicadora de alto ganho integrada, a qual converte a luz emitida pelos dosímetros em corrente (de $\mu \mathrm{C}$ a $\mathrm{nC}$ ). À medida em que os TL's são aquecidos, luz visível é emitida de cada cristal e detectada pela fotomultiplicadora, um Automatic Integrating Picoammeter Model 2000B (Harshaw/Nuclear Systems, EUA) amplifica e integra o sinal obtido. Em todas as leituras com os cristais, procurou-se repetir os mesmos procedimentos realizados, tais como, a mensuração da corrente que somente foi anotada após o TL atingir a temperatura de $250,0 \pm 0,5{ }^{\circ} \mathrm{C}$; a aquisição dos dados inicia-se a partir do momento em que a plataforma de aquecimento atingia $90,0 \pm 0,5{ }^{\circ} \mathrm{C}$; os TL's são lidos sempre com a face numerada voltada para baixo, dentre outras. Na tentativa de reduzir sinais espúrios durante as leituras, utilizou-se um fluxo de $\mathrm{N}_{2}(5 \pm 1 \mathrm{~L} / \mathrm{min})$ com a finalidade de produzir uma atmosfera inerte (aquecimento na ausência de $\mathrm{O}_{2}$ ), o que é crucial principalmente em medidas de pequenas doses (mGy) [217]. 
O mapa das doses absorvidas foi obtido pela média dos dados coletados de cada metade do plano iradiado, isto é, as matrizes de dados original, matriz $\mathbf{A}$, e sua rotação horizontal, matriz $\mathbf{B}$, foram adicionadas, resultando na matriz $\mathbf{C}$, conforme a Figura 2.10. Dessa matriz resultante, os valores foram divididos por dois e plotados como curvas de isodoses percentuais, considerando o valor central da imagem como $100 \%$.

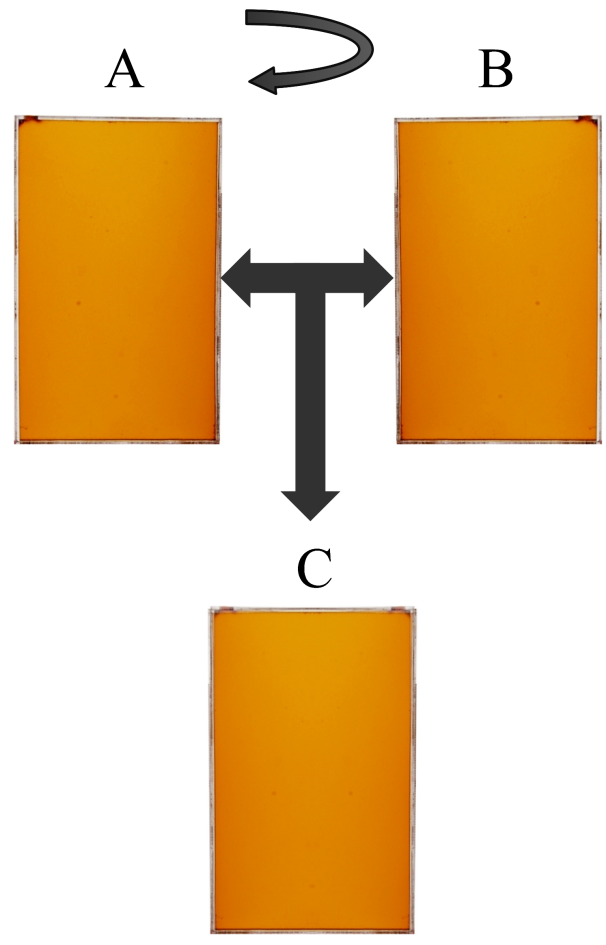

Figura 2.10. Esquema exibindo a obtenção dos planos de distribuição de dose por meio da média das matrizes de dados.

\subsubsection{Filme radiocrômico}

Outro dosímetro adotado como referência foi o filme do tipo EBT2, os quais já vêm sendo desenvolvidos para atender as necessidades da dosimetria na Radioterapia há mais de uma década e demonstraram adequação para feixes de raios X de $50 \mathrm{kVp}$ até $18 \mathrm{MV}$ [218]. De acordo com a brochura fornecida pelo fabricante, seu uso permite faixas de doses absorvidas entre 1 cGy e 1000 cGy, quando lido no canal vermelho por um sistema digital de aquisição, embora doses até 4000 cGy possam ser inferidas utilizando-se o canal verde. Além disso, sua resposta tem mostrado baixa dependência para energias de feixes de fótons de alguns keV até $\mathrm{MeV}(<10 \%$ ) [219], 
o que reduz as preocupações com os efeitos de espalhamento, permitindo que o filme seja utilizado para a energia de $662 \mathrm{keV}$ do ${ }^{137} \mathrm{Cs}$ [220]. Outra característica é que esse filme pode ser imerso em água para medidas dosimétricas que necessitem de objeto simulador tecido equivalente.

Os filmes do tipo EBT2 foram desenvolvidos para serem manuseados à luminosidade ambiente (excetuando-se UV), embora deva ser idealmente estocado em ambiente escuro. No quesito temperatura de estocagem, eles podem ser armazenados à temperatura ambiente (de 2 a $25^{\circ} \mathrm{C}$ ), apesar de ser o mais recomendado deixá-lo à temperaturas menores do que $0{ }^{\circ} \mathrm{C}$. Essa última prática pode aumentar ainda mais o tempo de estocagem padrão de dois anos.

Os filmes EBT2 podem ser lidos por densitômetros ou scanners de transmissão e espectrofotômetros. De fato, na literatura, as leituras de filmes radiocrômicos são comumente obtidas empregando-se um digitalizador (scanner) do tipo "transmissão" [221-223]. Não obstante, como o sistema de aquisição óptico compartilha do mesmo princípio desse tipo de scanner, tal sistema também foi escolhido para realizar as auferições do filme EBT2, em conjunto com o espectrofotômetro. Ao ser exposto à radiação ionizante, o componente ativo desse tipo de filme reage formando um polímero azulado com picos de absorção centrados nas bandas de 585 e $636 \mathrm{~nm}$. Apesar de já ter sido proposta leitura dos filmes no canal vermelho [224], neste trabalho optou-se em fazer as leituras com o sistema de aquisição $C C D$ no canal verde para o cálculo da grandeza R.I., Equação (2.2), devido à melhores razões sinal/ruído e faixa de linearidade. Já para o espectrofotômetro, a banda escolhida foi a centrada em $636 \mathrm{~nm}$. Um cuidado tomado durante as aquisições é que os pedaços de filmes fossem lidos sempre na mesma orientação.

\subsubsection{Simulação computacional PENELOPE}

De modo a simular as condições experimentais, um vasilhame cilíndrico com dimensões de 12,4 × 19,4 cm feito de aço, Figura 2.11(a), foi simulado dentro de uma blindagem de chumbo. As cubetas contendo FXG e água foram modeladas de acordo com a Figura 2.8 e irradiadas por uma fonte de ${ }^{137} \mathrm{Cs}$, também cilíndrica, com dimensões de 5,0 × 19,4 cm, semelhantemente à do irradiador específico. As distribuições da dose absorvida foram computadas considerando-se sete planos cen- 
trais com diferentes angulações $\left(0,15,30,45,60,75\right.$ e $90^{\circ}$ com relação ao eixo da fonte radioativa), conforme a Figura 2.11(b). Cada plano possuía $100 \times 100$ bins, o que configurava uma resolução espacial de $\approx 0,124 \mathrm{~cm}$ na horizontal $\mathrm{e} \approx 0,194 \mathrm{~cm}$ na vertical. As configurações acerca da enegia absorvida, dos parâmetros de espalhamento elástico e energias de corte para emissões bremsstrahlung e colisões inelásticas foram definidas de acordo com o recomendado pelo manual do PENELOPE. Após 2 $\times 10^{8}$ iterações, todos os planos foram somados com igual ponderação. A matriz resultante foi então "espelhada", como realizado anteriormente (Figura 2.10).

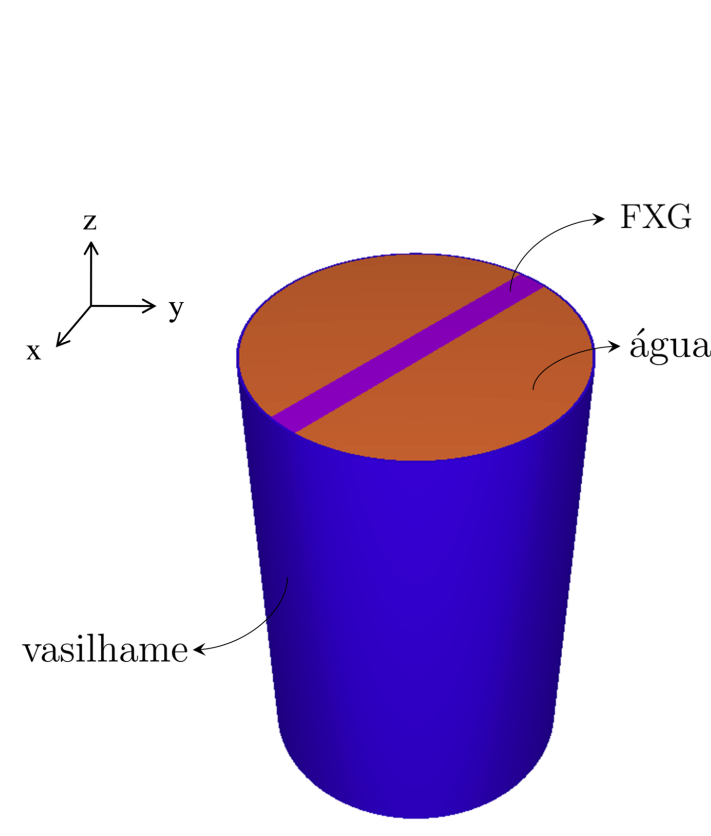

(a)

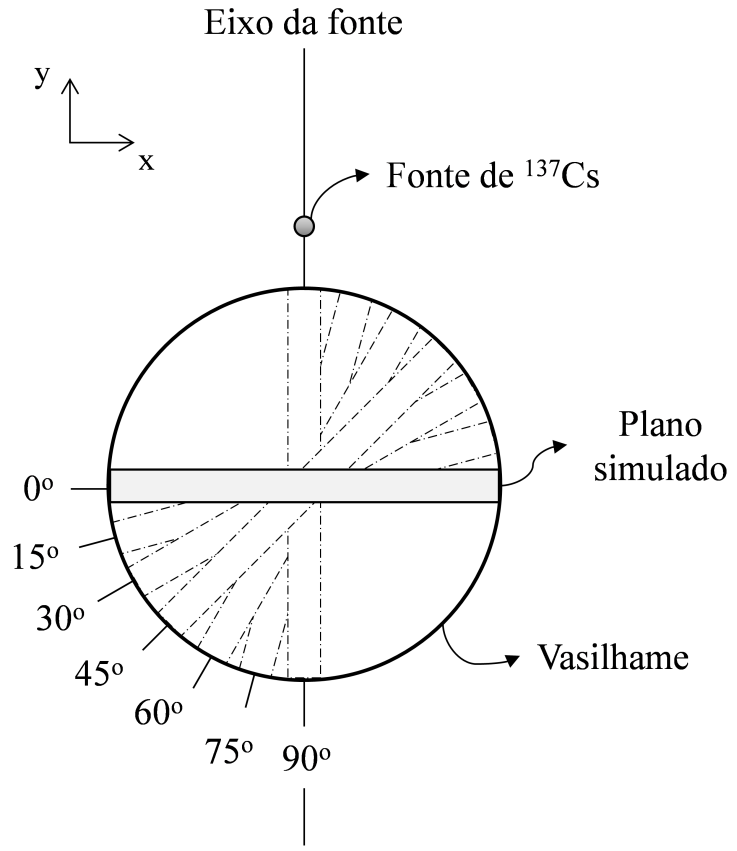

(b)

Figura 2.11. (a) Ilustração tridimensional dos objetos simulados no código PENELOPE e (b) as angulações utilizadas para reproduzir a rotação do vasilhame.

Após as simulações, os dados também foram tratados no MAtlaB ${ }^{\circledR}$ com dois diferentes filtros, um de média e outro do tipo Wiener. Outra situação simulada foi a da irradiação do vasilhame preenchido com sangue por uma fonte de ${ }^{60} \mathrm{Co}$, considerando a geometria de um equipamento teleterápico, isto é, uma distância fonte superfície $(S S D)$ de $80 \mathrm{~cm}$ e um campo de $25 \times 25 \mathrm{~cm}^{2}$. 


\subsection{Análises estatísticas}

Os dados das curvas de calibração foram obtidos pela média de 03 valores de absorbância, para o caso da espectrofotometria, e pela média do volume de uma cubeta, para o caso do sistema de aquisição $C C D$. Juntamente com as médias, os respectivos desvios-padrão foram computados e ambos utilizados nos cáculos das incertezas ${ }^{19}$. A fim de se ter sentido metrológico, a dose absorvida inferida sempre foi acompanhada por uma estimativa da incerteza, sendo tal estimativa dependente do sistema dosimétrico empregado. Assim, as incertezas associadas a cada medida foram estimadas de acordo com as respectivas avaliações do tipo A (estatísticas, como por exemplo desvios-padrão) e do tipo B (não estatísticas, como por exemplo precisão do equipamento), de acordo com a equação em primeira aproximação [225227]:

$$
\sigma_{y}^{2}=\sum_{i=1}^{N}\left(\frac{\partial f}{\partial x_{i}}\right)^{2} \sigma_{x_{i}}^{2}
$$

considerando

$$
y=f\left(x_{1}, x_{2}, \ldots, x_{N}\right)
$$

e

$$
\sigma_{x_{i}}^{2}=\sigma_{A x_{i}}^{2}+\sigma_{B x_{i}}^{2}
$$

$\sigma_{y} \quad:$ incerteza da grandeza calculada,

$\left(\frac{\partial f}{\partial x_{i}}\right) \quad$ : primeira derivada da função $f$ em relação à variável $x_{i}$,

na qual

y : grandeza calculada,

$f\left(x_{1}, x_{2}, \ldots, x_{N}\right): \quad$ equação que representa $y$ e dependente das variáveis independentes $x_{1}, x_{2}, \ldots, x_{N}$,

$\sigma_{x_{i}} \quad:$ incerteza associada à variável $x_{i} \mathrm{e}$

$\sigma_{A x_{i}}$ e $\sigma_{B x_{i}} \quad: \quad$ incertezas do tipo A e do tipo B da variável $x_{i}$.

\footnotetext{
${ }^{19}$ Parâmetro não negativo que caracteriza a dispersão dos valores atribuídos a um mensurando, com base nas informações utilizadas [203].
} 
Além dos cálculos das médias e dos desvios-padrão, fez-se uso também da técnica de análise de variância $(A N O V A)$. Esta análise estatística visa verificar a existência de diferenças entre médias e a influência significativa de alguma variável. O teste ANOVA é mais comumente utilizado ao se comparar modelos estatísticos que foram ajustados para determinado conjunto de dados, de modo a identificar o modelo que melhor se ajusta à população da qual os dados foram extraídos. O valor observado da estatística de teste $\mathrm{F}$ (F-test), um dos parâmetros calculados na ANOVA, é a razão entre a soma quadrática da regressão dividida pelo número de graus de liberdade $\left(M S_{r e g}\right)$ e a soma quadrática residual dividida pelo número de graus de liberdade $\left(M S_{\text {res }}\right)$. Quanto maior o valor dessa razão, maior a indicação de uma "boa" relação linear, já que o $M S_{\text {reg }}$ seria muito maior que o $M S_{\text {res }}$.

Além da estatística ANOVA, calculou-se também o Erro Padrão de Previsão $(S E P)$, uma grandeza que tem por finalidade quantificar a diferença na variabilidade entre os valores preditos e os de referência para dada validação. Através do $S E P$, é possível calcular um intervalo de confiança para os valores previstos usando uma função de calibração. Esse intervalo proporciona uma estimativa da incerteza associada com os valores previstos da variável em $x$. A equação que determina tal intervalo é a que segue:

$$
s_{x_{0}}=\frac{s(r)}{m} \sqrt{\frac{1}{N}+\frac{1}{n}+\frac{\left(\overline{y_{0}}-\bar{y}\right)^{2}}{m^{2} \sum_{i=1}^{n}\left(x_{i}-\bar{x}\right)^{2}}} .
$$

A partir da grandeza $s_{x_{0}}$, o intervalo de confiança para cada curva de calibração foi obtido multiplicando-se o valor $s_{x_{0}}$ pelo valor de $t$ tabelado, considerando uma distribuição t de Student bicaudal em um nível de confiança de 95 \%. Assim, o SEP foi utilizado em conjunto com a estatística $A N O V A$ e o coeficiente de correlação linear $(r)$ para analisar as respostas dos dosímetros testados e propor a receita do FXG mais adequada para a irradiação de sangue. 
RESULTADOS E DISCUSSÕES

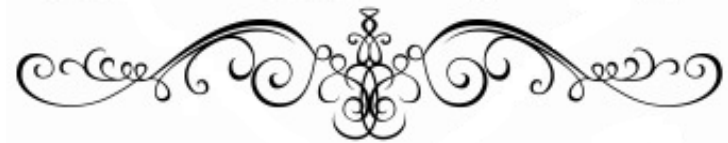




\section{Capítulo}

\section{RESULTADOS E DISCUSSÕES}

Neste capítulo, estão presentes os resultados obtidos segundo os procedimentos adotados no Capítulo 2. Como descrito na Apresentação, todos os dados representativos dos dosímetros FXG testados (dose absorvida, absorbância, variação de absorbância e sensibilidade) pela alteração nas concentrações do $\mathrm{FeSO}_{4}$, da gelatina, do ácido sulfúrico, do alaranjado de Xilenol e do cloreto de sódio, estão apresentados pelo símbolo (o), enquanto que os dados do dosímetro FXG original são apresentados na forma $(\triangle)$.

Embora nem sempre visíveis, todos os dados acima citados encontram-se acompanhados de suas respectivas incertezas $\sigma_{y}$ e $\sigma_{x}$, as quais foram obtidas de acordo com o apresentado na seção 2.5. Especificamente para a dose absorvida nominal, isto é, aquela fornecida por uma câmara de ionização calibrada, sua incerteza estimada foi de $\pm 3 \%$, devido às precisões de posicionamento, espessura das cubetas $(1,25 \pm 0,01 \mathrm{~cm})$ e tempo de trânsito da fonte radioativa.

Inicial e prioritariamente, as análises da caracterização do FXG foram realizadas utilizando-se o espectrofotômetro devido à disponibilidade do mesmo e à maior facilidade de se implementar a metodologia proposta neste trabalho, frente ao sistema de aquisição $C C D$ desenvolvido por nosso grupo ${ }^{1}$. Assim, o primeiro passo na caracterização do dosímetro foi a obtenção do seu espectro de absorbância e, como esperado, as receitas analisadas apresentaram duas bandas principais de absorção, uma em 440 e outra em 585 nm, Figura 3.1. O primeiro pico de absorbância cor-

\footnotetext{
${ }^{1} \mathrm{~A}$ validação do sistema de aquisição de imagens $C C D$ foi realizada por meio de curvas de calibração, tanto para o FXG original quanto para o proposto. Além disso, uma análise mais detalhada foi feita por SAMPAIO \& DEL LAMA [197].
} 
responde à presença de íons ferrosos $\left(\mathrm{Fe}^{+2}\right)$, de modo que seu valor tende a diminuir com o aumento da dose absorvida pelo FXG. Essa diminuição é explicada pela oxidação radio-induzida desses íons, em férricos $\left(\mathrm{Fe}^{+3}\right)$, os quais são os responsáveis pelo surgimento do pico em $585 \mathrm{~nm}$ após se agregarem ao alaranjado de Xilenol [137]. Essa banda de comprimento de onda é a que apresenta a maior sensibilidade para o FXG [1], conforme pode ser visualizado na Figura 3.2. De fato, a escolha dessa banda de absorção mostra-se adequada, uma vez que o coeficiente de extinção molar na região espectral do verde é aproximadamente sete vezes maior do que o da região UV (304 nm), o que acarreta maior sensibilidade para as deteções ópticas [148].

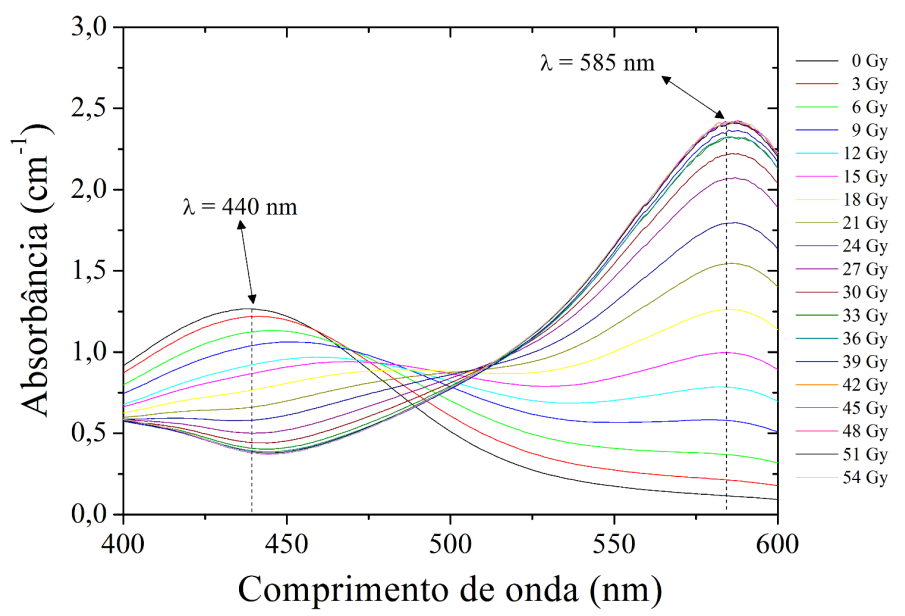

Figura 3.1. Espectros típicos de absorbância para diferentes doses absorvidas.

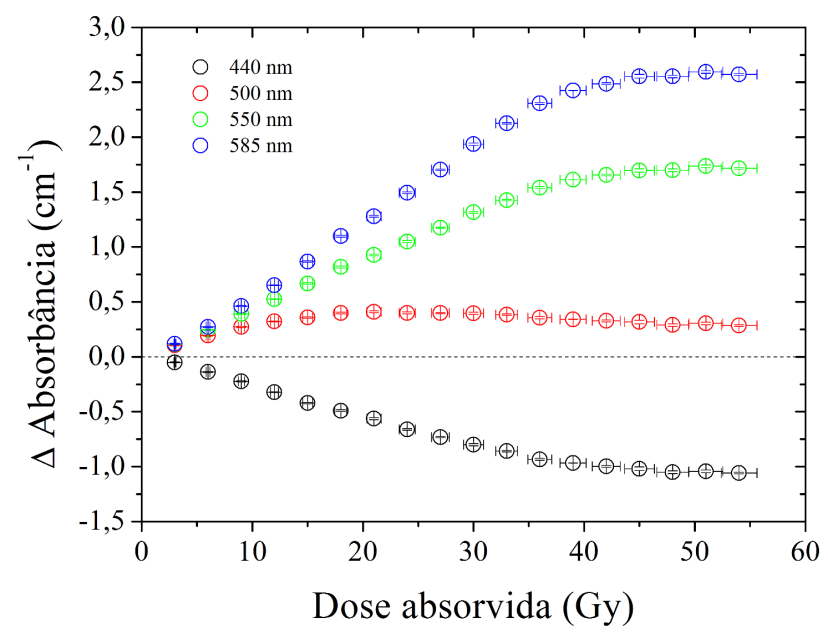

Figura 3.2. Valores da variação da Absorbância em função da Dose absorvida para diferentes comprimentos de onda. 
De acordo com o mencionado no capítulo anterior, para todas as amostras esperou-se em torno de 30 minutos entre as irradiações e a aquisição dos dados. Isso, embora sendo uma limitação física devido à localização do equipamento de cobalto (Hospital Beneficência Portuguesa Ribeirão Preto) e o espectrofotômetro (Hemocentro), era também uma necessidade, visto que existe um tempo de espera entre 5 e 10 minutos para que as reações químicas se estabilizem adequadamente [153,228]. Apesar da oxidação natural também ocorrer nesse intervalo de tempo entre a irradiação e a leitura, essas alterações podem ser consideradas negligenciáveis quando comparadas com às induzidas pela radiação ionizante ${ }^{2}$. Alguns autores defendem um tempo de espera de até 2 horas após a irradiação para que as moléculas do complexo $\mathrm{XO}-\mathrm{Fe}^{+3}$ se estabilizem [229], mas tendo em vista os resultados obtidos em nosso grupo de pesquisa e neste trabalho, esse tempo é considerado "longo" por conta do desvanecimento do sinal.

\subsection{Caracterização do dosímetro FXG}

Nesta seção estão presentes os resultados obtidos para as modificações realizadas na receita do FXG original. Parâmetros como linearidade, sensibilidade, desvanecimento do sinal, entre outros, são exibidos nas subseções que seguem. Tais resultados serviram como critérios para a escolha de uma receita de FXG que apresentasse características adequadas para a dosimetria da irradiação de sangue.

\subsubsection{Influência do oxigênio}

O primeiro parâmetro avaliado foi a influência do borbulhamento de ar durante o preparo das amostras, o que foi realizado aumentando-se a velocidade de rotação da "pulga" magnética até o surgimento de bolhas na solução. Isso foi estudado, pois sabe-se que rendimento químico dos íons férricos é diretamente influenciado pela presença ou ausência de oxigênio na solução, conforme as reações que seguem, conforme MAgeE et al [230]. Nelas é possível constatar, quimicamente, como o oxigênio influencia mais a oxidação dos íons ferrosos:

\footnotetext{
${ }^{2}$ Como será visto nas próximas subseções, a variação na sensibilidade do FXG nesse intervalo de tempo, são menores do que $1 \%$.
} 


$$
\begin{aligned}
& G\left(F e^{+3}\right)_{N_{2}} \rightarrow 2 G_{H_{2} O_{2}}+G_{O H}+\left(G_{H}+G_{e^{-}}\right) \quad \text { e } \\
& G\left(F e^{+3}\right)_{O_{2}} \rightarrow 2 G_{H_{2} O_{2}}+G_{O H}+3\left(G_{H}+G_{e^{-}}\right) .
\end{aligned}
$$

Alguns autores constataram aumentos de até $15 \%$ na sensibilidade de dosímetros FXG nos quais o $\mathrm{O}_{2}$ foi borbulhado [229]. Contudo, os mesmos autores reportaram que o aumento de $\mathrm{O}_{2}$ na solução diminui a estabilidade do dosímetro após a irradiação.

Os resultados presentes nas Figuras 3.3(a) e (b) não indicam aumento da linearidade de resposta, tampouco da sensibilidade devido ao aumento da oxigenação na solução. Isso pode ser explicado pelo fato da solução já ser suficientemente oxigenada em razão das baixas temperaturas de preparo. Todavia, os resíduos da regressão com o método dos Mínimos Quadrados apresentados para o dosímetro mais oxigenado foram, em geral, menores do que os preparados de maneira normal, Figura 3.3(c). Assim, uma maior exatidão na resposta pode ser obtida quando o dosímetro possui maiores concentrações de oxigênio dissolvidos na solução, ou seja, uma menor diferença entre a previsão da dose absorvida prescrita e o valor realmente observado. Além disso, a maior agitação garante a melhor dissolução da gelatina, evitando a formação de grânulos que possam prejudicar a análise espectrofotométrica. A partir desses resultados, todos os dosímetros FXG foram preparados com maior grau de agitação de suas soluções (surgimento de bolhas).

\subsubsection{Influência do sulfato ferroso amoniacal}

Para a finalidade desejada, isto é, a utilização do dosímetro tipo FXG na irradiação de sangue, um dos principais parâmetros que devem ser alterados na receita é a sua faixa de linearidade de resposta, a qual usualmente estende-se de 0 até $\approx 40$ Gy para o ${ }^{60} \mathrm{Co}$. Aumentos na $\left[\mathrm{FeSO}_{4}\right]$ não apresentaram mudanças no que tange ao intervalo de linearidade do dosímetro, Figura 3.4(a). De fato, os limites superiores de resposta em dose absorvida inferidos pelos dosímetros testados (saturação) não foram maiores do que os 39 Gy apresentado pelo FXG original. Como visto na figura citada, o $\mathrm{FeSO}_{4}$ não proporcionou melhorias observáveis nesse quesito ao ter sua concentração aumentada na solução. Isso é decorrente do fato de que a concentração utilizada no FXG já apresentar concentração suficiente de íons ferrosos 


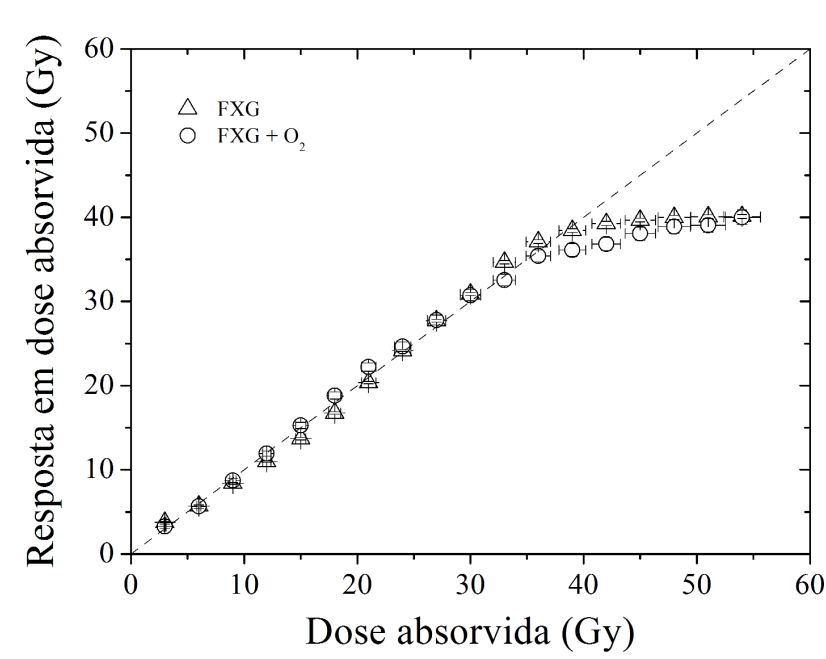

(a)

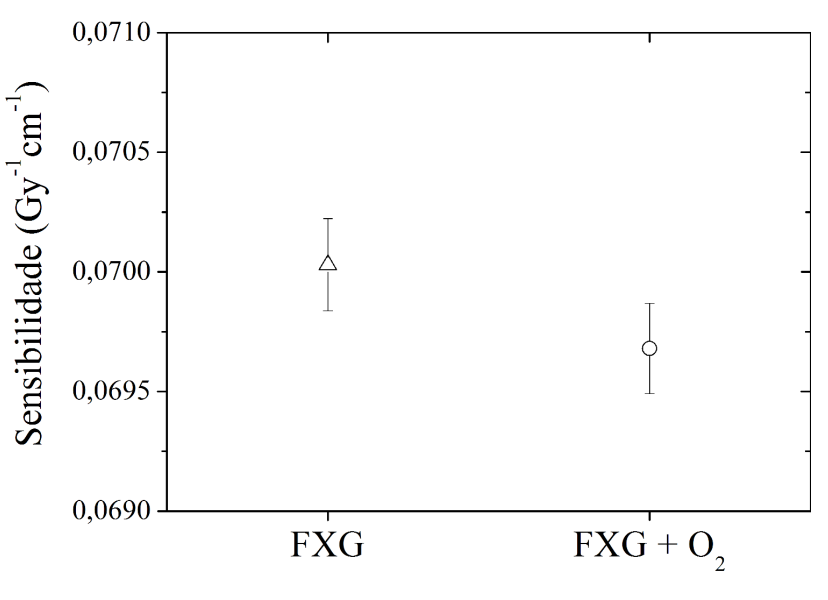

(b)

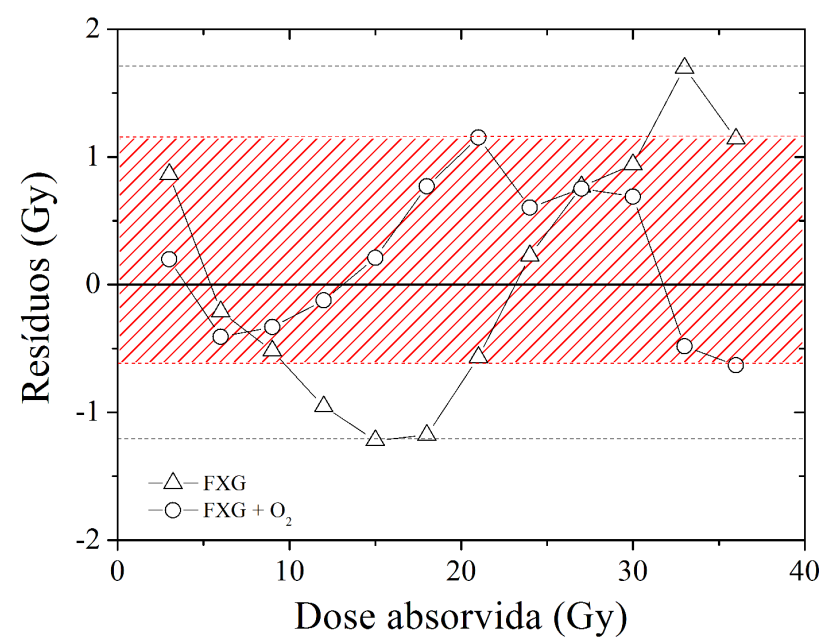

(c)

Figura 3.3. (a) Resposta da dose absorvida inferida versus dose absorvida nominal para o FXG com e sem borbulhamento. Em (b), sensibilidade para os dois tipos de dosímetros. (c) Resíduos dos ajustes lineares das curvas respostas para o FXG com (hachurado) e sem (pontilhado) borbulhamento.

$\left(\mathrm{Fe}^{+2}\right)$ para serem ionizados no intervalo de doses absorvidas estudado. Os valores de $G\left(F e^{+3}\right)$ para o FXG em um campo irradiado por ${ }^{60} \mathrm{Co}$, embora distinto para cada receita devido aos componentes utilizados, pode variar de 1,61 × $10^{-6} \mathrm{~mol} / \mathrm{J}$ $([129,204])^{3}$ até $1,68 \times 10^{-6} \mathrm{~mol} / \mathrm{J}[124]$. Adotando-se a média entre esses valores, temos que para cada $3 \mathrm{~Gy}$, isto é, para cada $3 \mathrm{~J} / \mathrm{kg}$, aproximadamente $5,0 \times 10^{-6}$

\footnotetext{
${ }^{3} \mathrm{Na}$ segunda referência, o valor-G deve ser multiplicado por $1,037 \times 10^{-7}$ para se obter o rendimento químico em conformidade com o ICRU [119]
} 
mol de $\mathrm{Fe}^{+2}$ será oxidado por quilograma de FXG. Como em $100 \mathrm{ml}$, há $6,3 \times 10^{-5}$ mol de $\mathrm{Fe}^{+2}$ e $105,4 \mathrm{~g}$ de dosímetro, isso implica em $\approx 6,0 \times 10^{-4} \mathrm{~mol} \mathrm{de} \mathrm{Fe}^{+2}$ por $\mathrm{kg}$ de dosímetro que pode ser oxidado em $\mathrm{Fe}^{+3}$. Dessa forma, para cada irradiação de 3 Gy, seriam possíveis até $6,0 \times 10^{-4} / 5,0 \times 10^{-6}=120$ irradiações de $3 \mathrm{~Gy}$ ( $\approx 350 \mathrm{~Gy}$ ). Dessa maneira, uma vez que é sabido que a reação $X O-\mathrm{Fe}^{+3}$ ocorre na proporção de 1:1 [228], o número de irradiações acima ficaria limitado pela concentração de Xilenol $^{4}$. Essa análise conduz, então, à apresentação dos estudos relacionados ao indicador Xilenol, que pode ser um dos fatores limitantes para a faixa de linearidade de resposta. Portanto, a abordagem para aumentar a faixa de trabalho do FXG não teve como rumo aumentos na concentração de sulfato ferroso amoniacal.

A sensibilidade do FXG está intimamente relacionada ao $G\left(F e^{+3}\right)$, podendo chegar até a uma ordem de grandeza maior que a do Fricke padrão, dependendo dos componentes utilizados [153]. Esse tipo de efeito acaba por ser de interesse prático, pois permite distinguir com o FXG doses absorvidas mais próximas, contudo promove limitações no quesito aquisição do sinal quando técnicas ópticas são empregadas (aumento nos níveis de absorbância). Assim, a sensibilidade para cada $\left[\mathrm{FeSO}_{4}\right]$ também foi averiguada e, como observado na Figura 3.4(b), nenhuma variação na sensibilidade pode ser atribuída à variação da $\left[\mathrm{FeSO}_{4}\right]$, excetuando-se para a concentração mais baixa. Novamente, isso conduz à ideia de que a $\left[\mathrm{FeSO}_{4}\right]$ já encontra-se elevada o suficiente para a sua oxidação nesta faixa de doses absorvidas.

Apesar da concentração de sulfato ferroso não afetar significativamente a sensibilidade do FXG, a estabilidade do dosímetro é fortemente influenciada tanto no período pré- quanto pós-irradiação. A concentração de sulfato ferroso e o desvanecimento temporal dos dosímetros são grandezas diretamente proporcionais, Figura 3.4(c). Em um período de 4 h, a leitura foi reduzida em até $16 \%$ para o dosímetro com maior concentração de $\mathrm{FeSO}_{4}$, frente à apenas $2 \%$ do $\mathrm{FXG}$ original. Conforme constatado, à medida que se aumenta a concentração de íons $\mathrm{Fe}^{+2}$ na solução, tanto a oxidação natural quanto o desvanecimento tendem a ser acelerados. De fato, a oxidação natural é proporcional ao quadrado da concentração de íons ferrosos [231] e não pode ser evitada devido ao oxigênio dissolvido na água que invariavelmente

\footnotetext{
${ }^{4} \mathrm{Na}$ verdade, os valores de absorbância para amostras irradiadas com tais doses seriam impraticáveis, levando em consideração técnicas ópticas de espectrofotometria.
} 


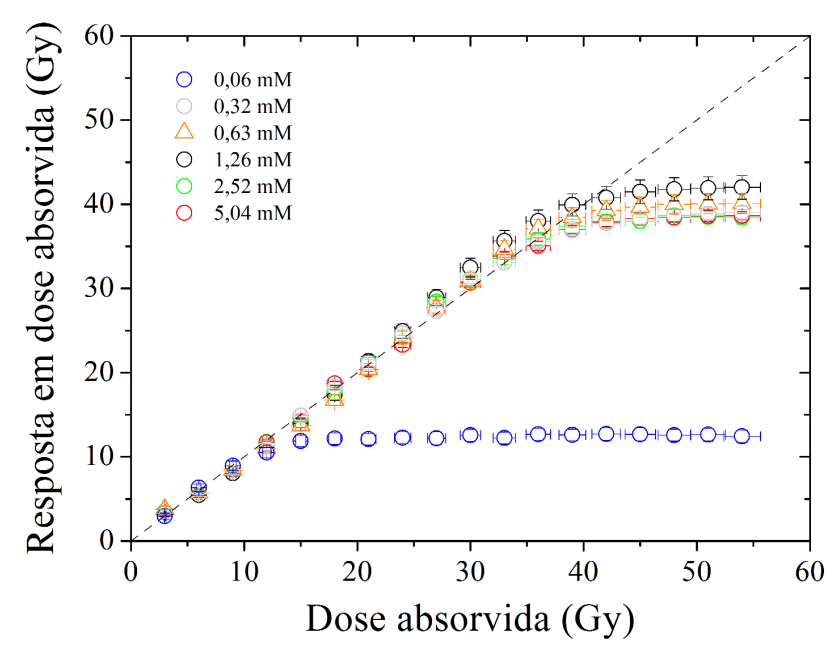

(a)

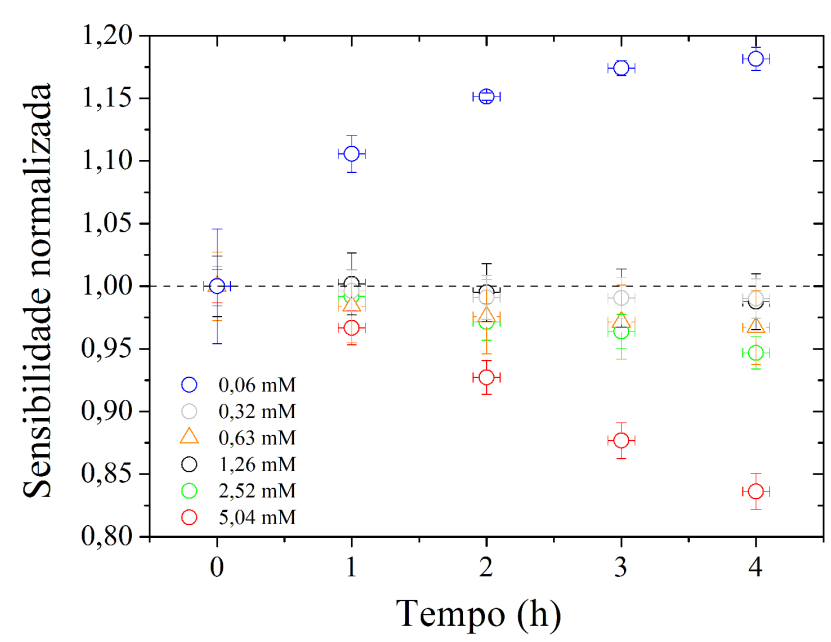

(c)

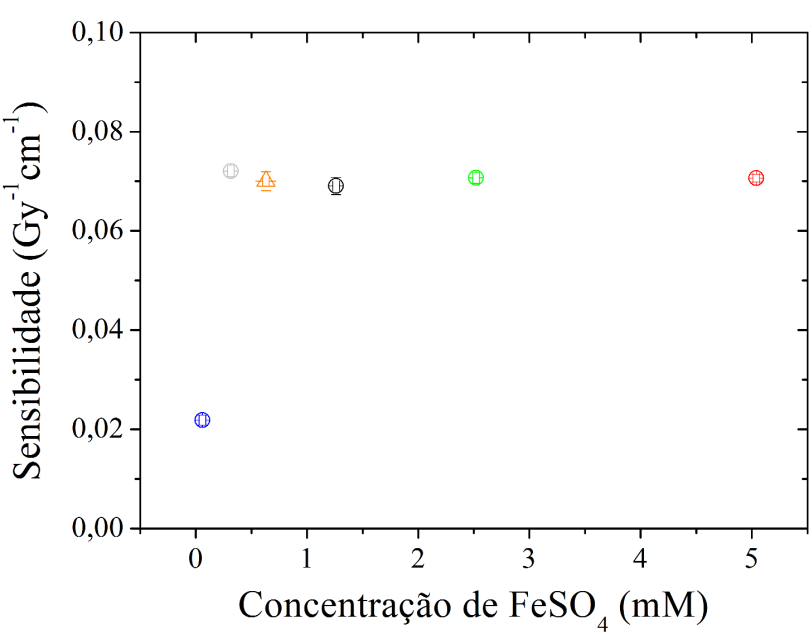

(b)

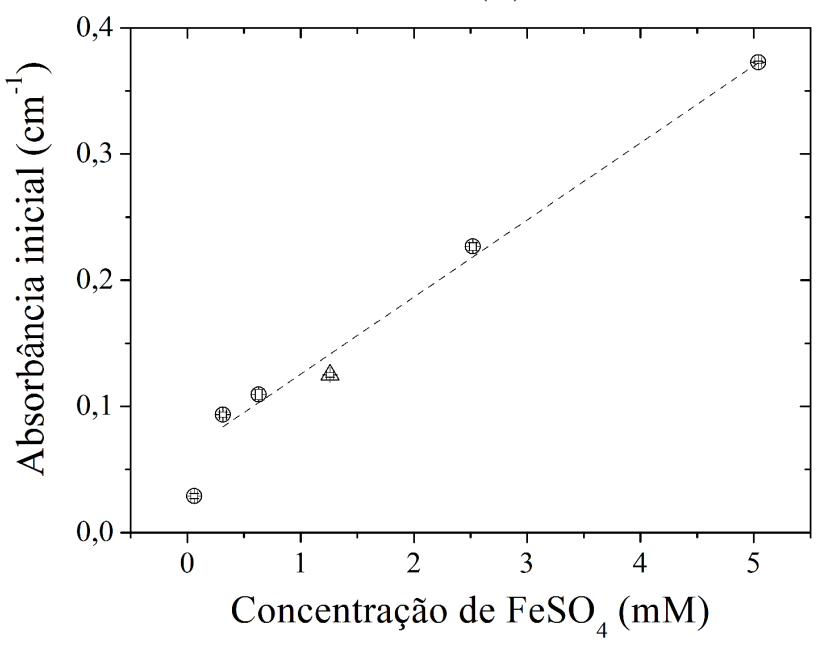

(d)

Figura 3.4. Caracterização do dosímetro FXG original para diferentes concentrações de $\mathrm{FeSO}_{4}$ em termos de (a) linearidade, (b) sensibilidade, (c) desvanecimento do sinal após a irradiação e (d) absorbância inicial.

constitui o dosímetro. A temperatura de armazenamento também acaba sendo um parâmetro importante nesse ponto; quanto menor a temperatura, menor é a variação da absorbância em função do tempo [146,232], o que implica em maior exatidão ao se inferir a dose absorvida. Fora isso, o sulfato ferroso apresenta um determinado nível de pureza $(\leq 0,02 \%)$, o qual indica a quantidade de íons férricos naturalmente presentes. Assim, ao aumentar a $\left[\mathrm{FeSO}_{4}\right]$, a concentração de íons $\mathrm{Fe}^{+3}$ na solução tornou-se maior devido à presença desses íons no componente (pureza). Com isso, tanto o desvanecimento do sinal, Figura 3.4(c), quanto o valor da sua absorbância 
inicial, isto é, aquela do dosímetro não irradiado, Figura 3.4(d), aumentaram com a concentração de sulfato ferroso amoniacal. O padrão linear existente entre a $\left[\mathrm{FeSO}_{4}\right]$ e a absorbância inicial revela que o aumento da quantidade de $\mathrm{FeSO}_{4}$ na solução não ocasionou nenhuma alteração química significativa em relação àquele do FXG original. Em outras palavras, isso indica que os íons ferrosos, $\mathrm{Fe}^{+2}$, encontram-se ligados da mesma maneira que no FXG, de modo que a absorbância aumenta simplesmente devido ao aumento da concentração de íons férricos, $\mathrm{Fe}^{+3}$, conforme prevê a Lei de Lambert-Beer, equação (2.2). Como visto nos resultados da Figura 3.4, a adequação do dosímetro FXG não considerará aumentos na concentração de $\mathrm{FeSO}_{4}$, mas sim, reduções.

\subsubsection{Influência da gelatina}

A contribuição da gelatina na resposta do dosímetro FXG foi estudada considerando-se diferentes concentrações da mesma, durante o preparo dos dosímetros. A Figura 3.5(a) exibe curvas de linearidade de resposta da dose absorvida inferida em função da dose absorvida nominal. Como pode ser visto, a saturação depende inversamente da concentração da gelatina, o que fica nítido comparando-se as curvas de 0,00 e 248,75 \pm 0,62 mM. Com a completa remoção da gelatina da receita, embora o comportamento em resposta de dose absorvida esteja em uma faixa de linearidade adequada para aplicações na Hemoterapia, é perdida uma das principais vantagens em se utilizar o FXG, que seria a possibilidade de se inferir a distribuição espacial da dose absorvida no dosímetro. Além da dificuldade na manipulação do dosímetro e consequente perda na capacidade de inferência espacial da dose, a falta de gelatina promove também, redução na sensibilidade do dosímetro. Isto indica que a gelatina pode ser entendida como uma espécie de catalisador da reação, a qual fornece um maior número de radicais livres para a oxidação do $\mathrm{Fe}^{+2}$. O aumento da concentração de gelatina no dosímetro apresentou efeitos deletérios na resposta da dose absorvida do FXG. De fato, elevadas concentrações de gelatina levaram à diminuição da sensibilidade do dosímetro como mostra a Figura 3.5(b), o que é corroborado por outros estudos [136, 229].

O desvanecimento do sinal do FXG também depende fortemente da concentração da gelatina. Como pode ser visto na Figura 3.4(c), em um período de $4 \mathrm{~h}$ a 


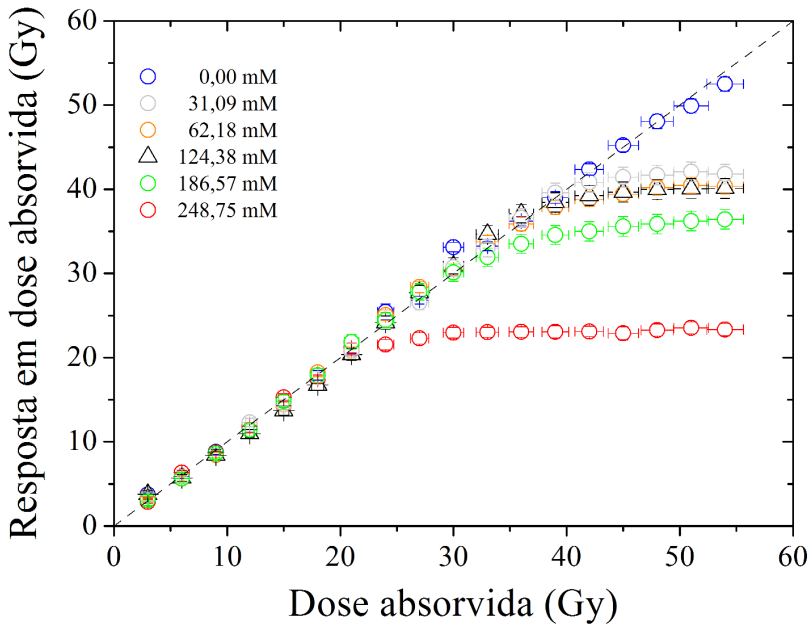

(a)

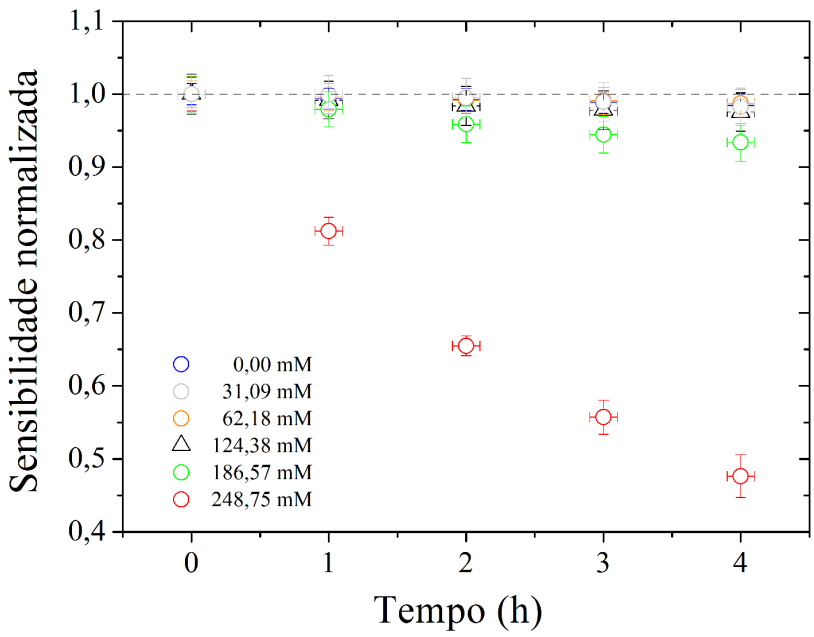

(c)

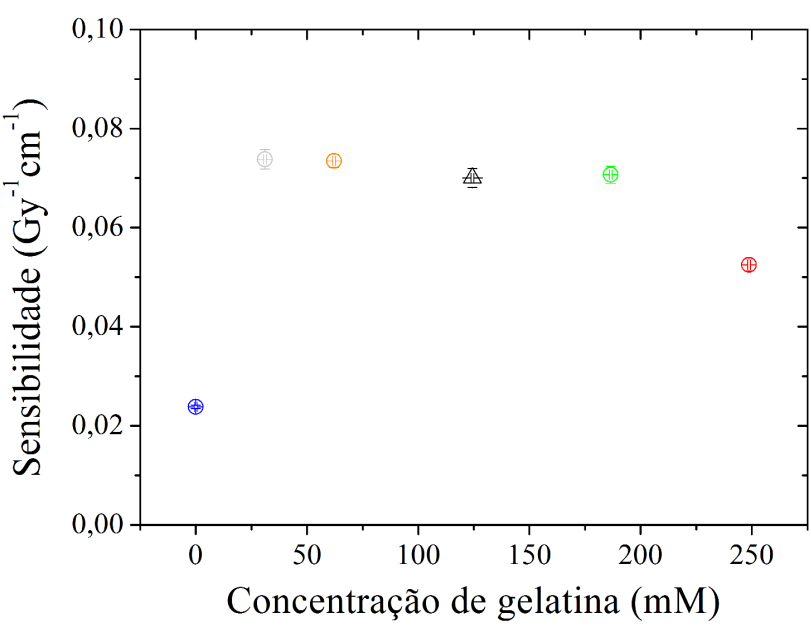

(b)

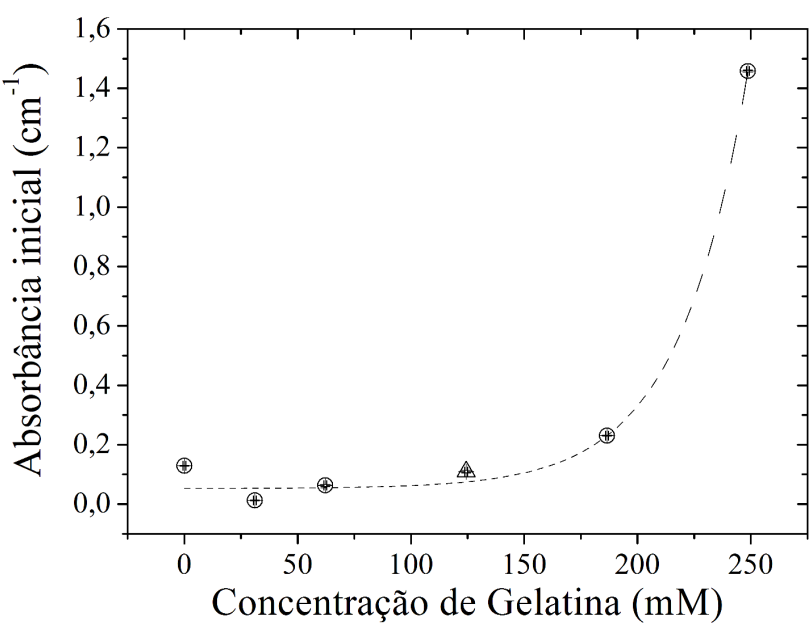

(d)

Figura 3.5. Caracterização do dosímetro FXG para diferentes concentrações de gelatina em termos de (a) linearidade, (b) sensibilidade, (c) desvanecimento do sinal após a irradiação e (d) absorbância inicial.

sensibilidade foi reduzida em mais de $50 \%$, para o caso do dosímetro com maior concentração desse componente. Para os casos de maiores concentrações de gelatina, os desvanecimentos dos sinais foram consideravelmente superiores ao do FXG original. Esse comportamento é resultante da maior concentração de matéria orgânica em cada dosímetro, o que acarreta maior disponibilidade de radicais livres para oxidarem os íons ferrosos e consequente perda de informação.

Conforme visto na Figura 3.5(d), a absorbância aumentou exponencialmente com o aumento da concentração da gelatina, que mostra um comportamento análogo 
ao caso do $\mathrm{FeSO}_{4}$, isto é, à medida que se aumenta a concentração da gelatina na solução, a oxidação natural tende a ser acelerada. Tal efeito também não é desejado para o dosímetro proposto e, portanto, a adequação do FXG não levará em consideração aumentos na concentração de gelatina.

\subsubsection{Influência do ácido sulfúrico}

De modo geral, foi observada uma relação bem estabelecida entre as respostas obtidas pelo FXG e o seu pH. O pH controla o equilíbrio químico da radiólise da água e, consequentemente, a taxa associada à produção de radicais livres. Elevados valores de $\mathrm{pH}(>2,0)$, isto é, soluções mais alcalinas, promovem a prematura oxidação dos íons $\mathrm{Fe}^{+2}$, o que resulta em efeitos de saturação precoces ( $\approx 30$ - $40 \mathrm{~Gy}$ ) e a redução na linearidade de respostas $(r<0,985)$. Em contraste, um $\mathrm{pH}$ mais baixo $(1,3<$ $\mathrm{pH}<1,8)$ diminui a produção de radicais livres e aumenta o intervalo de resposta linear. Essa característica é desejável, uma vez que permite a determinação de doses absorvidas tão altas quanto $50 \mathrm{~Gy}$, as quais são atualmente recomendadas pelos guias internacionais de controle de qualidade em Hemoterapia. Esse intervalo de pH também resultou em maiores valores de coeficientes de correlação linear $(r>$ 0,995). Para valores muito baixos de $\mathrm{pH}(<1,3)$, a ligação entre os íons $\mathrm{Fe}^{+3}$ e o $X O$ pode ser dissociada, acarretando em perda de dados ao longo do tempo. Para todo o intervalo estudado de pH's, a estrutura química da gelatina pareceu não ter sido seriamente afetada, ao se considerar o grau de liquefação do dosímetro para soluções mais ácidas.

A concentração de ácido na solução proporcionou as maiores alterações de comportamento linear do dosímetro, Figura 3.6(a), visto que esse componente pondera a radiólise da água, a qual é responsável por uma série de reações que geram radicais livres que culminam com a alteração da cor do dosímetro (ligação $X O-\mathrm{Fe}^{+3}$ ). Isso pode ser entendido pelas reações de hidrólise abaixo:

$$
\begin{aligned}
\mathrm{H}_{2} \mathrm{O}+\mathrm{e}_{a q}^{-} & \rightleftharpoons \mathrm{H}+\mathrm{OH}^{-}, \\
H O_{2} & \rightleftharpoons H^{+}+\mathrm{O}_{2}^{-} \quad \mathrm{e} \\
O H & \rightleftharpoons H^{+}+\mathrm{O}^{-} .
\end{aligned}
$$


Os produtos gerados nas reações acima, juntamente com os radicais livres, são os principais responsáveis pela oxidação dos íons ferrosos em férricos. Com elevadas concentrações de ácido sulfúrico, a concentração inicial de $\mathrm{H}^{+}$na solução é elevada, o que evita a geração de produtos nas reações apresentadas, conforme prevê a teoria do equilíbrio químico. Isto porque, quando há mais produtos do que reagentes, a reação direta não ocorre à mesma velocidade que a inversa, promovendo uma alteração no equilíbrio químico das reações (3.4)-(3.5). Conforme visto na Figura 3.6(a), concentrações elevadas de ácido sulfúrico (como 97,44 e 121,95 \0,07 mM) possibilitaram a inferência de doses absorvidas de 0 até 54 Gy. Porém, a sensibilidade tendeu a diminuir linearmente a partir da concentração de $\approx 40 \mathrm{mM}$, Figura 3.6(b). De fato, elevadas concentrações de ácido levam à diminuição da sensibilidade uma vez que, como existem menos radicais livres provenientes da radiólise da água, a reação de oxidação ocorre em uma proporção mais lenta.

Com elevadas concentrações de ácido, as sensibilidades tenderam a aumentar ao longo do tempo após a irradiação, Figura 3.6(c). Para as concentrações de 48,78; 73,17 e 97,44 mM, os dosímetros apresentaram sensibilidades ligeiramente mais estáveis entre 1 e $3 \mathrm{~h}$ após a primeira leitura, diferentemente dos comportamentos relacionados à alteração de sulfato ferroso, gelatina. Para esses últimos casos, a sensibilidade tendeu apenas a diminuir ao longo do tempo. A estabilidade, mostrada sobretudo para a concentração de $73,17 \mathrm{mM}$, indica que ocorre uma diminuição da velocidade de oxidação com aumento da concentração de ácido sulfúrico e mostrase como uma característica desejável para o dosímetro, especialmente quando um considerável período de tempo é necessário entre a irradiação e a mensuração do sinal.

O aumento da $\left[\mathrm{H}_{2} \mathrm{SO}_{4}\right]$ na solução do dosímetro tendeu a diminuir o valor da absorbância inicial, Figura 3.6(d), o que novamente pode ser entendido considerandose a influência que o ácido exerce sobre a geração de radicais livres e consequente agregação dos íons férricos com o XO. Como nos demais casos, baixos valores de absorbância são de interesse prático por conta da precisão da resposta dos equipamentos ópticos de leitura.

Pelos dosímetros testados, percebeu-se que o coeficiente de correlação linear $(r)$ sofreu influências significativas com as diferentes concentrações de ácido sulfúrico. 


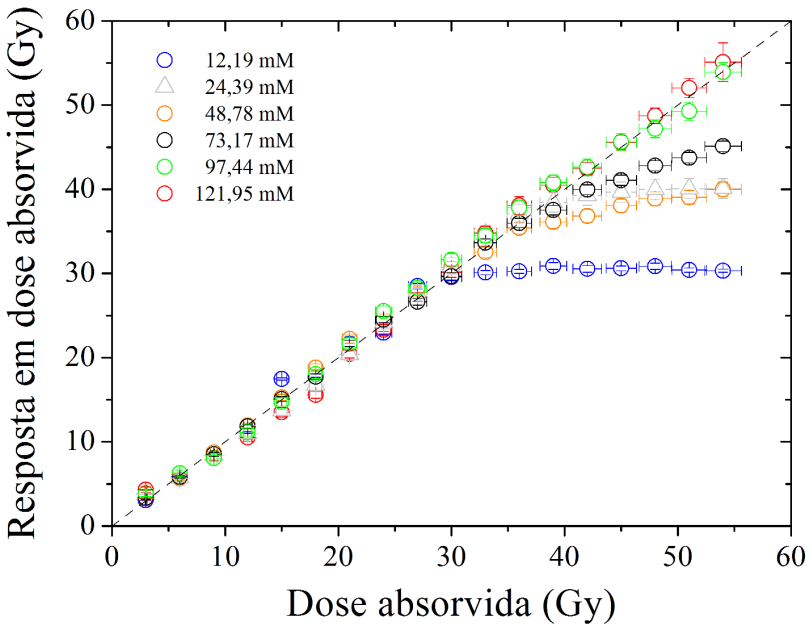

(a)

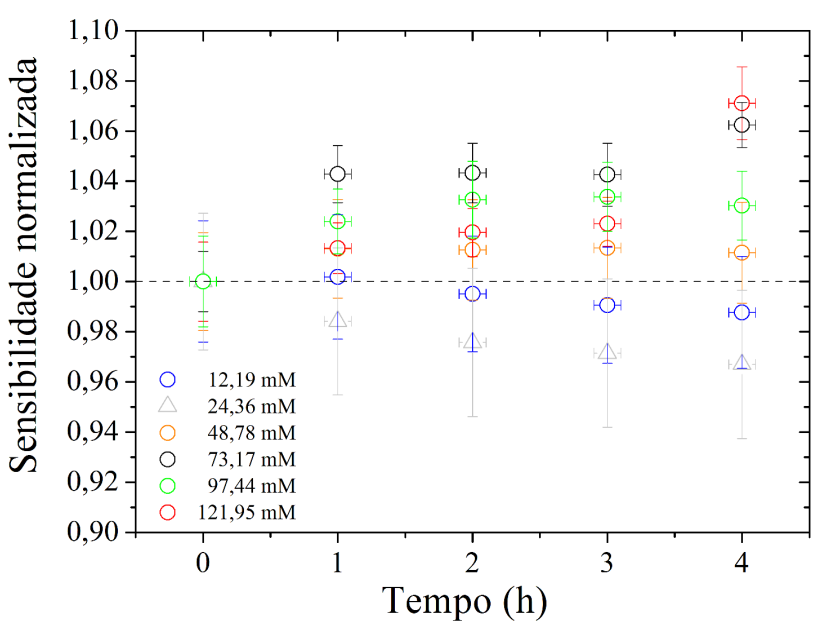

(c)

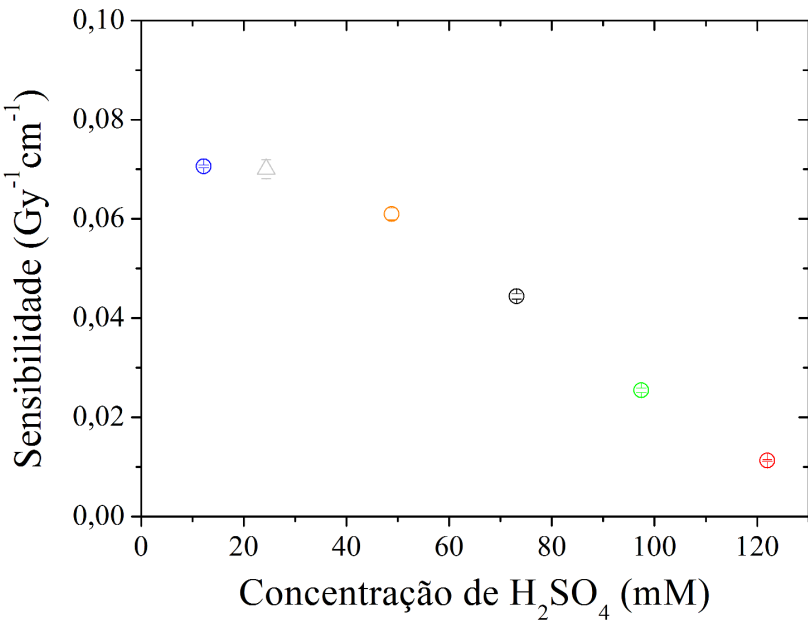

(b)

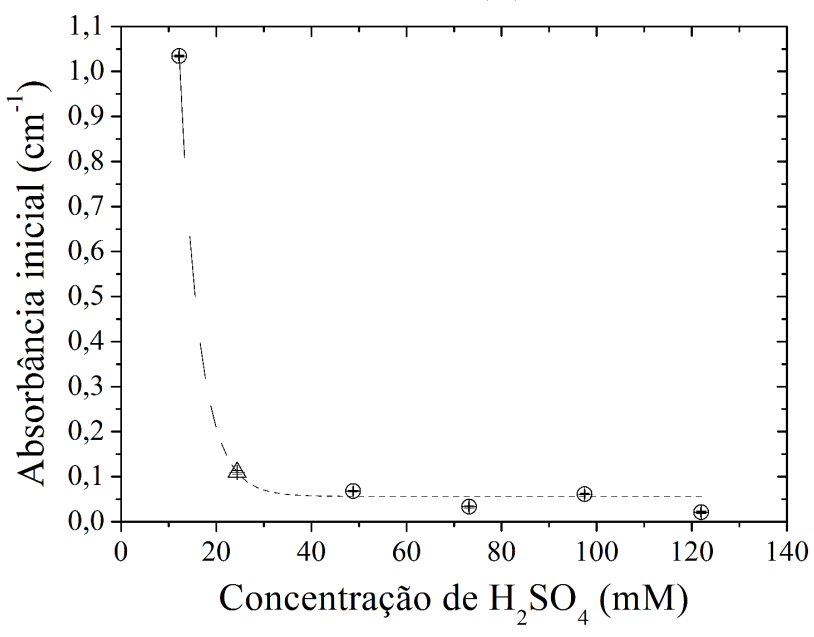

(d)

Figura 3.6. Caracterização do dosímetro FXG para diferentes concentrações de $\mathrm{H}_{2} \mathrm{SO}_{4}$ em termos de (a) linearidade, (b) sensibilidade, (c) desvanecimento do sinal após a irradiação e (d) absorbância inicial.

Em geral, quanto mais ácida era a receita, menos linear era a reta, o que pode ser explicado pela alteração na proporção das espécies ionizadas e, consequente, alteração no coeficiente de extinção molar da solução [233]. Dessa forma, de acordo com os resultados obtidos para a variação da $\left[\mathrm{H}_{2} \mathrm{SO}_{4}\right]$, soluções mais ácidas permitiram um aumento no intervalo de linearidade do dosímetro, contudo tenderam a reduzir sua linearidade $(r)$ e sensibilidade. Portanto, a receita FXG proposta considerará soluções mais ácidas que a original e que apresentem valores de $\Delta \mathrm{A}$ dentro do intervalo de precisão do espectrofotômetro, com adequados níveis de sensibilidade. 


\subsubsection{Influência do alaranjado de Xilenol}

Em condições ideais, com cada componente do dosímetro possuindo concentrações adequadas para a faixa de doses absorvidas pretendidas, a coloração do FXG deve graduar-se de laranja para um marrom-avermelhado. A partir do momento em que as amostras passam a apresentar uma coloração roxa-azulada, isto indica que existe concentração insuficiente de $X O$ para complexar todos os íons férricos radio-oxidados $[137,234]$. Como essa última coloração é característica do FXG original para doses maiores do que $40 \mathrm{~Gy}$, procurou-se analisar a influência da $[X O]$ na resposta do dosímetro.

O aumento da concentração do indicador alaranjado de Xilenol $(X O)$ foi uma alteração que também gerou grande contribuição para o aumento do intervalo de linearidade do FXG, Figura 3.7(a). Para maiores concentrações de $X O$, os dosímetros testados tenderam a mostrar linearidade por toda a faixa de $[0 ; 54]$ Gy, com uma ligeira diminuição da sua sensibilidade, conforme visto na Figura 3.7(b). Para o caso do dosímetro com $0,25 \mathrm{mM}$ de $X O$, a diminuição na sensibilidade foi próxima de $14 \%$ em relação à do FXG original. Apesar dessa diminuição, o intervalo de linearidade para o dosímetro foi ampliado e doses absorvidas tão altas quanto 54 Gy puderam ser inferidas. Para a menor concentração de $X O$, isto é, metade daquela do dosímetro FXG original, foi percebido que o valor de saturação foi reduzido em praticamente igual proporção, permitindo inferência de doses absorvidas para valores não maiores do que $24 \mathrm{~Gy}$.

A estabilidade temporal do dosímetro não foi severamente influenciada pela concentração do $X O$, Figura 3.7(c), o que pode ser inferido ao longo de todo o período de análise de $4 \mathrm{~h}$, nas quais as leituras desvaneceram similarmente as do dosímetro FXG original . Para variações da $[X O]$, suas absorbâncias inicial do dosímetro não apresentaram variações significativas, Figura 3.7(d).

Um ponto a ser citado é que os dosímetros com elevadas [XO] apresentam tonalidades marrom-avermelhadas muito similares entre uma dose e outra, o que torna mais dificultoso discernir visualmente (qualitativamente) as alterações radioinduzidas na cor. Todavia, tanto o espectrofotômetro quanto o sistema digital $C C D$ foram capazes de realizar tal diferenciação. Além disso, é sabido que maiores $[X O]$ acarretam maior repetitividade de resposta para o FXG [229], o que foi mais nítido 
para a dependência na concentração do $X O$ do que para os demais componentes do dosímetro.

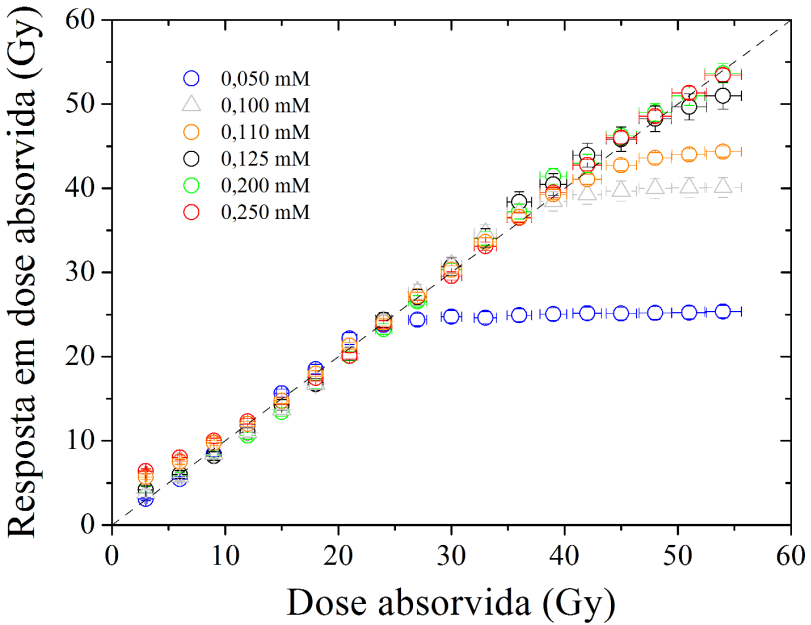

(a)

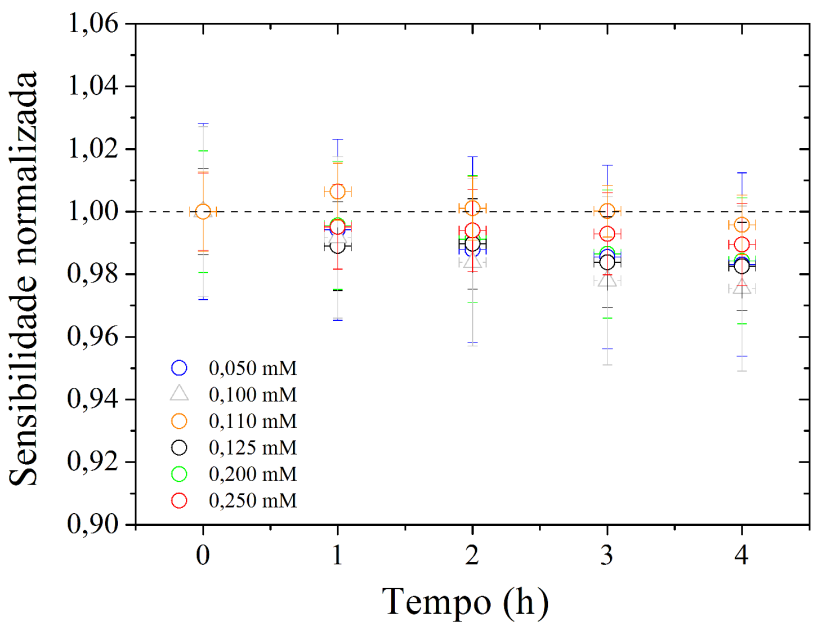

(c)

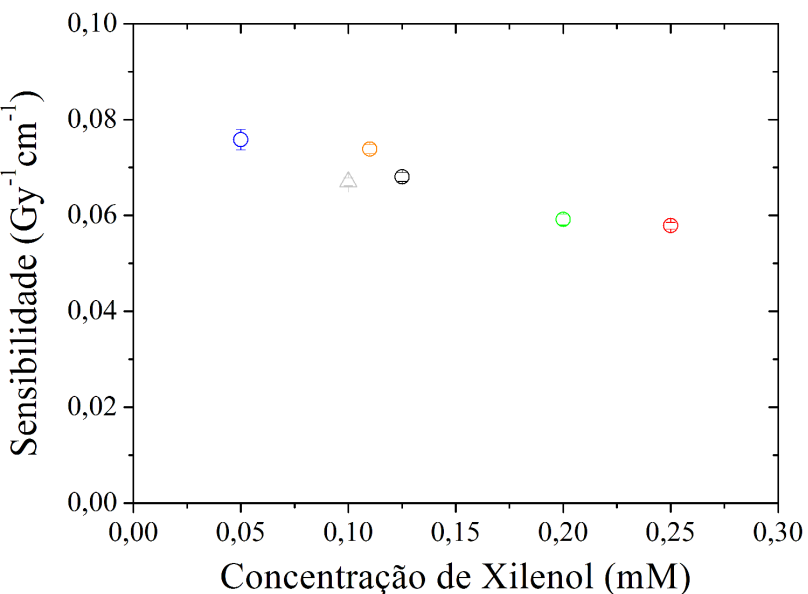

(b)

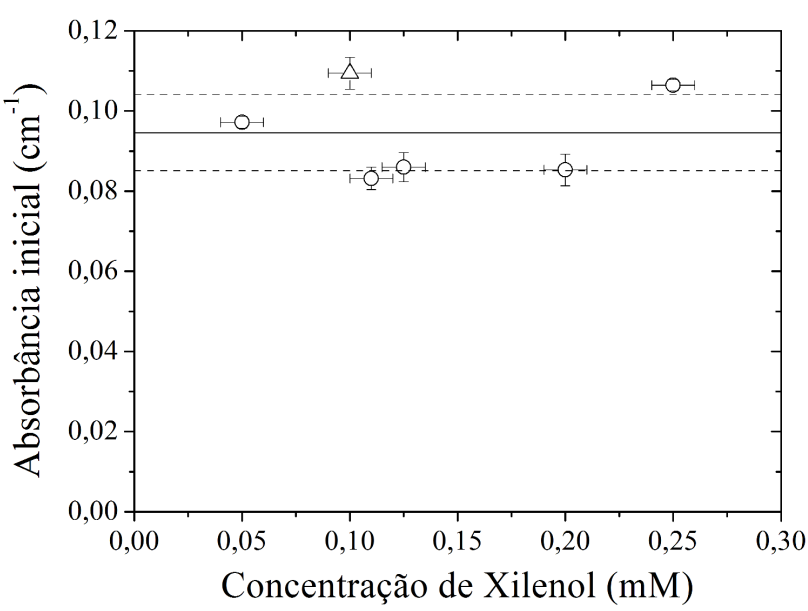

(d)

Figura 3.7. Caracterização do dosímetro FXG original para diferentes concentrações de $X O$ em termos de (a) linearidade, (b) sensibilidade, (c) desvanecimento do sinal após a irradiação e (d) absorbância inicial.

De modo geral, foi percebido que maiores concentrações de $X O$ proporcionaram maiores intervalos de linearidade para o FXG. Como mencionado antes, as moléculas de $X O$ ligam-se ao $\mathrm{Fe}^{+3}$ na razão de 1:1 e, embora a receita original do FXG apresente concentração de sulfato ferroso capaz de proporcionar respostas lineares para doses bem maiores do que as empregadas na $\operatorname{Hemoterapia}^{5}$, a concentração de $X O$ da

\footnotetext{
${ }^{5}$ Vide sub-seção 3.1.2.
} 
receita original não respeita a razão acima. Similarmente ao pH da solução ${ }^{6}$, a concentração de $X O$ original também mostrou-se como um dos fatores responsáveis para os efeitos de saturação entre 30 e 40 Gy para o FXG original. Assim, além de alterações envolvendo a acidez da solução, a receita proposta deverá considerar modificações quanto à concentração de $X O$, de modo a permitir linearidade em todo o intervalo utilizado para a prevenção da DECH-AT.

\subsubsection{Influência do cloreto de sódio}

Como explicado no Capítulo 1, durante o processo primário da absorção da radiação ionizante pela água ocorre a decomposição desta, resultando em átomos de $\mathrm{H}^{+}$e radicais $\mathrm{OH}^{-}$(Equações 1.2-1.4), os quais levam à formação de outros tipos de íons/radicais que promovem a oxidação dos íons ferrosos (Equações 1.5-1.9). O cloreto de sódio ao ser adicionado na solução, tem seus íons $\mathrm{Na}^{+}$e $\mathrm{Cl}^{-}$dissociados e a seguinte reação tende a ocorrer:

$$
\mathrm{Cl}^{-}+\mathrm{OH}+\mathrm{H}^{+} \rightarrow \mathrm{Cl}+\mathrm{H}_{2} \mathrm{O} \text {. }
$$

Isso faz com que os átomos $\mathrm{Cl}$ tendam prioritariamente a oxidarem os íons ferrosos ao invés desses últimos serem oxidados por moléculas orgânicas, resultantes da radiólise da água [235], o que faz com que a reação de oxidação seja menos dependente de possíveis impurezas presentes, principalmente, na gelatina.

Para qualquer instrumento/dosímetro, destinado à um programa de controle de qualidade, a repetitividade é uma importante característica ser analisada. A partir das concentrações de cloreto de sódio estudadas, notou-se que a presença ou ausência desse composto não promoveram alterações significativas na linearidade, na sensibilidade ou no desvanecimento temporal do sinal, as quais foram semelhantes às do FXG original. A alteração mais perceptível foi em termos de repetitividade de resposta, em especial para a concentração de 0,63 $\pm 0,05 \mathrm{mM}$ de $\mathrm{NaCl}$. Conforme exibe a Tabela 3.1, esta concentração de $\mathrm{NaCl}$ foi capaz de promover diminuição nas incertezas associadas à $\Delta \mathrm{A}$, a partir do cálculo de propagação das incertezas, Equação (2.3), com os valores médios e respectivos desvios-padrão de a e b. De

\footnotetext{
${ }^{6}$ Vide sub-seção 3.1.4.
} 
acordo com os cálculos, as incertezas propagadas foram, em geral, uma ordem de grandeza menores para os dosímetros contendo $\mathrm{NaCl}$.

Além de impurezas orgânicas, outros contribuintes para o aumento ou diminuição da repetitividade das respostas dos dosímetros FXG são as qualidades da água MilliQ e do ácido súlfurico. Quanto à água Milli-Q, procurou-se sempre utilizar a água do mesmo equipamento de modo a não alterar o comportamento dos dosímetros testados. Quanto ao ácido sulfúrico, este foi adquirido de fabricantes reconhecidos e sua manipulação foi realizada segundo as normas de segurança.

Tabela 3.1. Repetitividade da resposta do dosímetro FXG em função da presença $(0,63 \pm 0,05 \mathrm{mM})$ e ausência de $\mathrm{NaCl}$.

\begin{tabular}{c||cc}
\hline \multirow{2}{*}{ Receita } & \multicolumn{2}{c}{ Desvio padrão da média (\%) } \\
\cline { 2 - 3 } FXG & 7,80 & $\mathbf{b}^{*}$ \\
\hline FXG $+\mathrm{NaCl}$ & 3,27 & 0,46 \\
\hline
\end{tabular}

* Os parâmetros a e b representam, respectivamente, os coeficientes linear e angular da reta de ajuste para as curvas de calibração entre as variações de absorbância e as doses absorvidas: $\Delta \mathrm{A}=\mathbf{a}+\mathbf{b} \cdot D$

\subsection{Proposição do novo dosímetro FXG}

\subsubsection{Incertezas associadas à variação da absorbância}

Nos gráficos da Figura 3.8 encontram-se as incertezas em função de $\Delta \mathrm{A}$ para as concentrações e os componentes estudados. Em todos os experimentos (receitas), as incertezas tenderam a aumentar proporcionalmente à variação de absorbância. Além disso, notou-se que as incertezas tenderam a variar mais bruscamente para duas situações: quando o dosímetro estava prestes a saturar e quando os valores de $\Delta \mathrm{A}$ eram maiores do que $\approx 2,0 \mathrm{~cm}^{-1}$. A primeira situação é esperada e está relacionada com a variação estatística dos dados, em que os valores flutuam em torno de uma média. A segunda está relacionada ao fato de que o espectrofotômetro apresenta um intervalo ótimo de trabalho, no qual as incertezas são percentualmente 
menores. Dessa maneira, tais gráficos também contribuíram na escolha das concentrações selecionadas para o dosímetro proposto, as quais estão dispostas na próxima subseção.

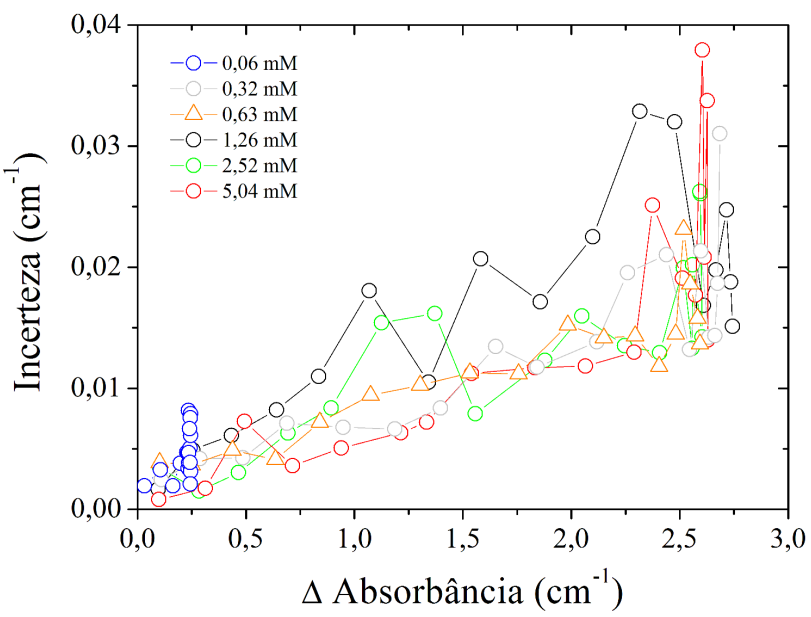

(a)

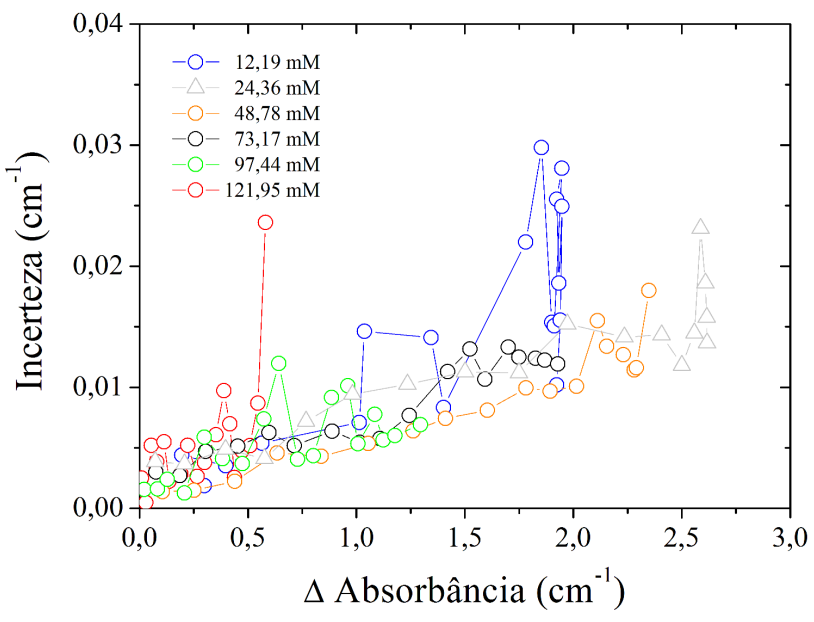

(c)

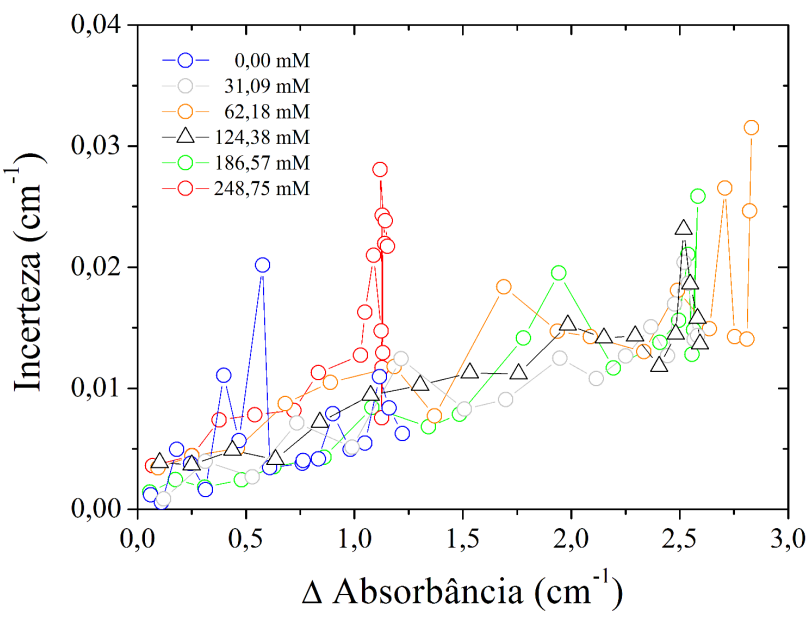

(b)

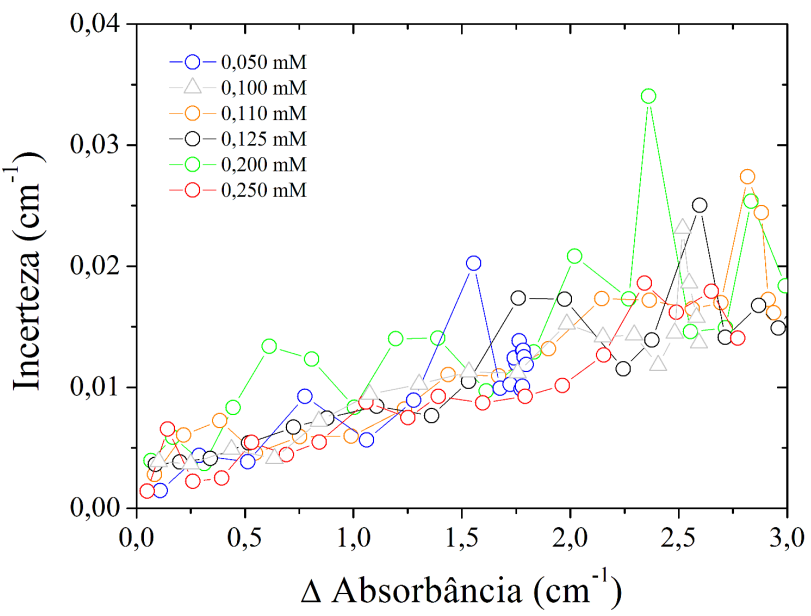

(d)

Figura 3.8. Incertezas em função da variação da Absorbância $\Delta \mathrm{A}$, considerando os estudos envolvendo (a) o sulfato ferroso, (b) a gelatina, (c) o ácido sulfúrico e (d) o alaranjado de Xilenol.

\subsubsection{Receita proposta}

A partir dos resultados de caracterização obtidos nas subseções anteriores, novas concentrações foram propostas para os componentes a fim de adequar a resposta do FXG às necessidades da irradiação do sangue. Dessa forma, as concentrações empregadas para o dosímetro proposto foram: 
- 0,32 \pm 0,03 mM para o $\left[\mathrm{FeSO}_{4}\right]$, em contraste com $0,63 \pm 0,03 \mathrm{mM}$ para a receita original;

- $124,38 \pm 0,62 \mathrm{mM}$ para a [gelatina], a mesma concentração da receita original;

- 73,17 \pm 0,07 mM para o $\left[H_{2} S O_{4}\right]$, em contraste com 24,39 $\pm 0,07 \mathrm{mM}$ para a receita original;

- $0,250 \pm 0,008 \mathrm{mM}$ para o $[X O]$, em contraste com 0,100 $\pm 0,008 \mathrm{mM}$ para a receita original e

- $0,32 \pm 0,05 \mathrm{mM}$ para o $[\mathrm{NaCl}]$, que foi adicionada à receita original.

A concentração escolhida de sulfato ferroso no dosímetro proposto foi de 0,32 mM, uma vez que esta já apresenta íons ferrosos suficientes para doses absorvidas tão altas quanto 50 Gy. Além disso, para essa concentração, a taxa de desvanecimento do sinal é menor do que para o FXG original e existe menor probabilidade de escurecimento prematuro da amostra, devido à contaminação por íons férricos (pureza do componente). A concentração da gelatina ficou inalterada em 124,38 mM, visto que essa concentração apresenta boa consistência para o dosímetro e valores adequados de sensibilidade. O ácido sulfúrico teve sua concentração aumentada para 73,17 mM, devido a maior estabilidade obtida após 1 hora de irradiação e à $\Delta \mathrm{A}$ máximas em torno de $2,5 \mathrm{~cm}^{-1}$. A concentração de $0,25 \mathrm{mM}$ foi escolhida para o $X O$, pois esta era a principal limitante para a saturação do FXG. O cloreto de sódio teve sua concentração estabelecida em $0,32 \mathrm{mM}$, devido aos menores desvios-padrão apresentados.

\subsection{Comparação dos dosímetros FXG proposto e original}

Nas subseções seguintes, uma série de testes comparativos foi realizada entre os dosímetros proposto e original. Por meio desses testes foi possível analisar a adequabilidade do novo dosímetro FXG, para a dosimetria e controle de qualidade no processo de irradiação de sangue ${ }^{7}$.

\footnotetext{
${ }^{7}$ No Apêndice B encontram-se alguns cuidados para a realização da dosimetria utilizando o dosímetro FXG.
} 


\subsubsection{Espectro de absorbância}

Os espectros de absorbância do novo dosímetro FXG são exibidos na Figura 3.9 em função da dose absorvida. Como visto, os picos máximos de absorbância não foram significativamente deslocadas pela alteração das concentrações dos componentes e indica que leituras de variações de absorbância $\Delta \mathrm{A}$ ainda podem ser adquiridas na banda de $585 \mathrm{~nm}$. As modificações mais perceptíveis que ocorreram no espectro do novo dosímetro em comparação com o FXG original foram o alargamento da banda de absorção e a diminuição dos valores de $\Delta \mathrm{A}$. O alargamento da banda de absorção pode ser explicado pela maior concentração de $X O$ na nova receita, uma vez que esse componente apresenta dois picos de absorção, um em 434 e outro em 576 nm. Já os menores valores de absorbância no novo dosímetro estão correlacionados com as maiores concentrações de ácido sulfúrico, que tendem a retardar a oxidação dos íons ferrosos.

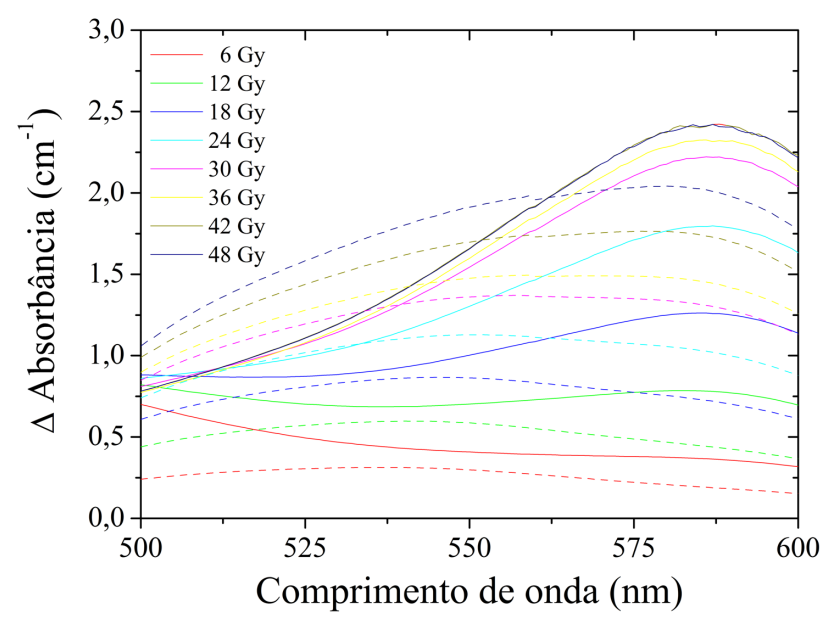

Figura 3.9. Comparação entre os espectros da variação da absorbância para os dosímetros FXG original (linha contínua) e proposto (linha tracejada).

\subsubsection{Dependência com a temperatura durante a irradia- ção do FXG}

A resposta do FXG é sensível à temperatura durante a irradiação [236,237], bem como à temperatura durante a leitura [161,238]. A dependência com a temperatura durante a irradiação para a resposta do FXG original foi de 0,13 $\pm 0,01 \%$ por ${ }^{\circ} \mathrm{C}$, medido com o espectrofotômetro, estando em razoável acordo $(<10 \%)$ com aquelas disponíveis na literatura $\left(\approx 0,12 \%\right.$ por $\left.{ }^{\circ} \mathrm{C}\right)[239,240]$. Outros autores já 
reportaram dependências até quatro vezes maiores $\left(\approx 0,53 \%\right.$ por $\left.{ }^{\circ} \mathrm{C}\right)[161]$, o que poderia estar relacionado com os componentes utilizados no preparo. Quanto à técnica $C C D$, esta revelou uma dependência em torno de $0,21 \pm 0,02 \%$ por ${ }^{\circ} \mathrm{C}$ para o dosímetro original. Essa maior dependência para a técnica $C C D$, em comparação à espectrofotometria, está relacionada à menor sensibilidade dessa última técnica. Já o dosímetro FXG proposto demonstrou dependência bem menos significativa com a temperatura de irradiação para as duas técnicas de análise, sendo esta uma característica desejável, devido às diferentes temperaturas que os hemocomponentes necessitam ser mantidos.

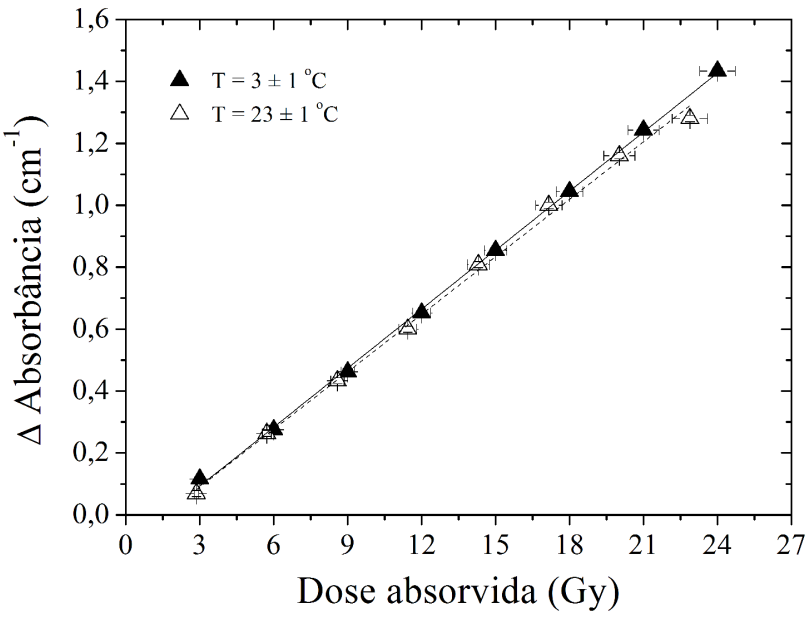

(a)

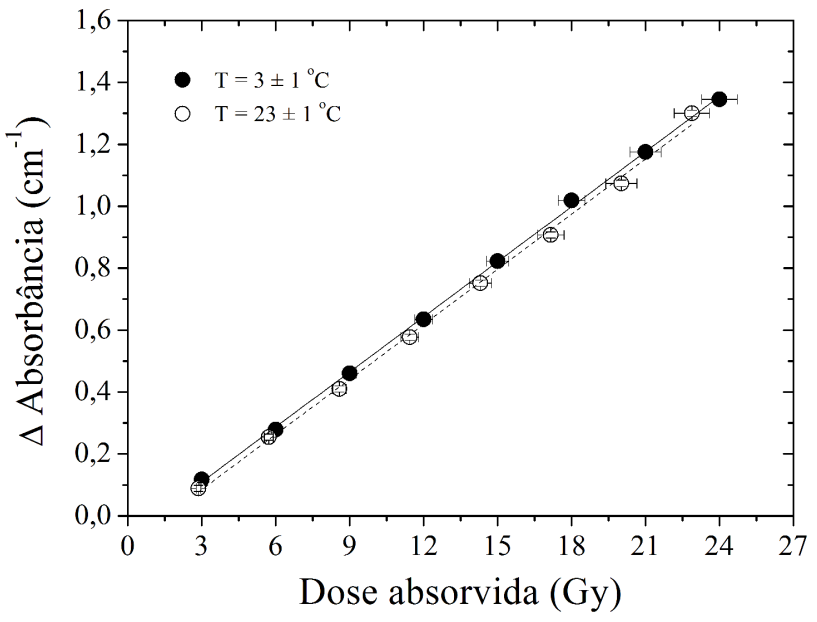

(b)

Figura 3.10. Variação da Absorbância em função da Dose Absorvida para amostras irradiadas a (a) 3 e (b) $23 \pm 1{ }^{\circ} \mathrm{C}$, utilizando-se a técnica espectrofotométrica.

\subsubsection{Dependência com a taxa de dose absorvida e ener- gia}

A independência com a taxa de dose absorvida é uma característica bastante desejável para qualquer dosímetro, visto que isso possibilita uma maior aplicabilidade sob diversas circunstâncias sem a necessidade de um fator de correção. De acordo com alguns autores, as respostas dos dosímetros químicos independem da taxa de dose para moderadas alterações desta grandeza [137,167,231]. Os resultados obtidos tanto pelo FXG original quanto pelo proposto corroboram com essa afirmação, conforme pode ser inferido pelos gráficos da Figura 3.11(a) e (b). Como pode ser constatado, ambos apresentaram variações não dependentes com a taxa de dose, 
de modo que suas respostas relativas flutuaram em $\pm 5 \%$ em torno da média. O filme EBT2 indicou uma tendência em diminuir sua resposta relativa em absorbância conforme a taxa de dose aumentou, Figura 3.11(c), o que também é confirmado por outros autores [192, 220,241]. Com relação aos dosímetros TL's (LiF-100), a literatura [241] mostrou que não há uma dependência considerável com a taxa de dose.

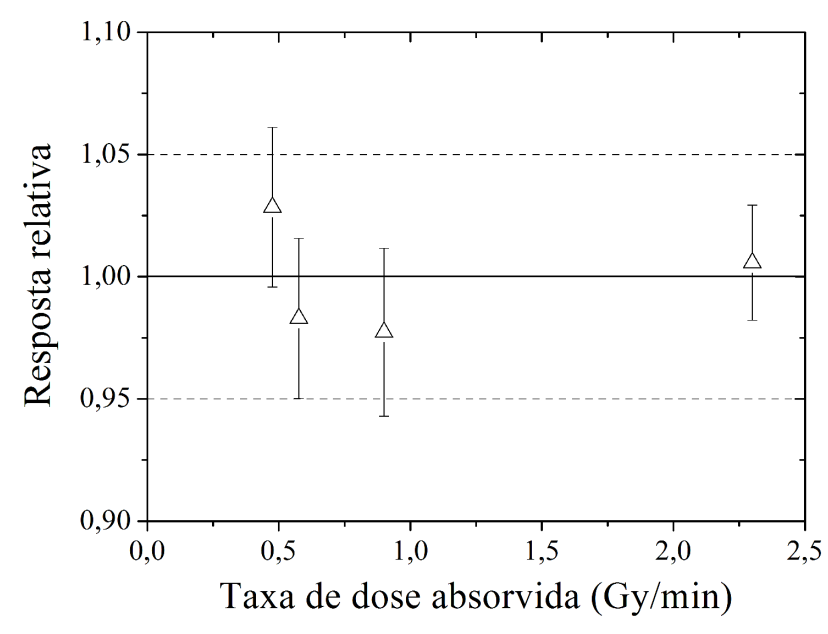

(a)

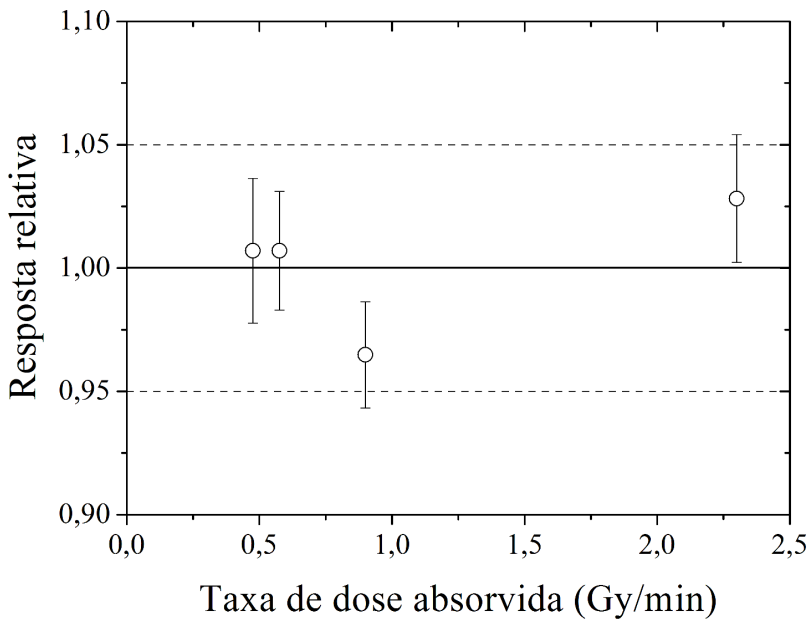

(b)

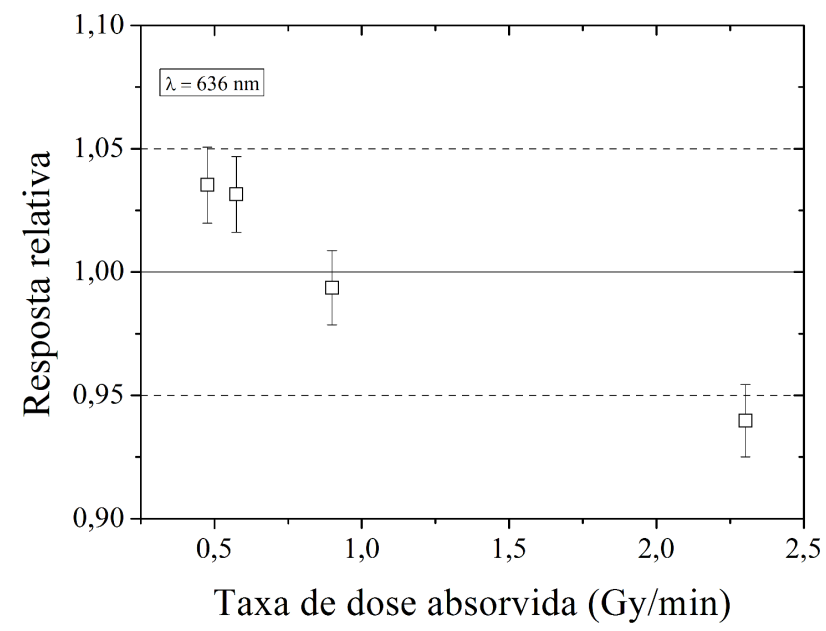

(c)

Figura 3.11. Respostas relativas em absorbância versus dose absorvida para diversas taxas de doses absorvidas irradiando o FXG com o ${ }^{60}$ Co. (a) FXG original, (b) FXG proposto e (c) filme radiocrômico.

A Figura 3.12 exibe as curvas de calibração para os dosímetros FXG original e o proposto, para diferentes energias de fótons. O dosímetro original apresentou 
dependência mais significativa em sua sensibilidade $\left(0,0967 \pm 0,0023 \mathrm{~cm}^{-1} / \mathrm{Gy}\right.$ versus $0,0682 \pm 0,001 \mathrm{~cm}^{-1} /$ Gy para o feixe de raios $\mathrm{X}$ de $6 \mathrm{MV}(\approx 2,0 \mathrm{MeV})$ e para $\mathrm{o}{ }^{60} \mathrm{Co}$, respectivamente), a qual mostrou-se diretamente proporcional à energia utilizada. Já o FXG proposto indicou baixa dependência energética entre os feixes de $6 \mathrm{MV}$ e de ${ }^{60} \mathrm{Co}\left(0,0496 \pm 0,0006 \mathrm{~cm}^{-1} /\right.$ Gy versus $0,0471 \pm 0,0005 \mathrm{~cm}^{-1} / \mathrm{Gy}$, respectivamente), mostrando-se mais adequado para os equipamentos rotineiramente utilizados na irradiação de sangue.

A saturação da resposta do FXG original também apresentou-se diretamente proporcional ao valor da energia, isto é, quanto maior a energia da radiação, mais rapidamente é a saturação do dosímetro em função da dose. Este comportamento também pode ser notado no dosímetro proposto, no qual a resposta apresentou indícios não-lineares para doses absorvidas superiores à $\approx 45 \mathrm{~Gy}$. A diminuição do intervalo de linearidade pode ser entendida considerando-se a dependência do rendimento químico, $G\left(F e^{+3}\right)$, com a transferência linear de energia $(L E T)$, isto é, com a densidade de ionizações liberadas ao longo do caminho percorrido por fótons ou partículas no meio irradiado [231]. O LET das partículas aumenta com o aumento da energia inicial do feixe radioativo e disponibiliza uma maior quantidade de ionizações nos dosímetros do tipo FXG, induzindo a saturação da sua resposta.

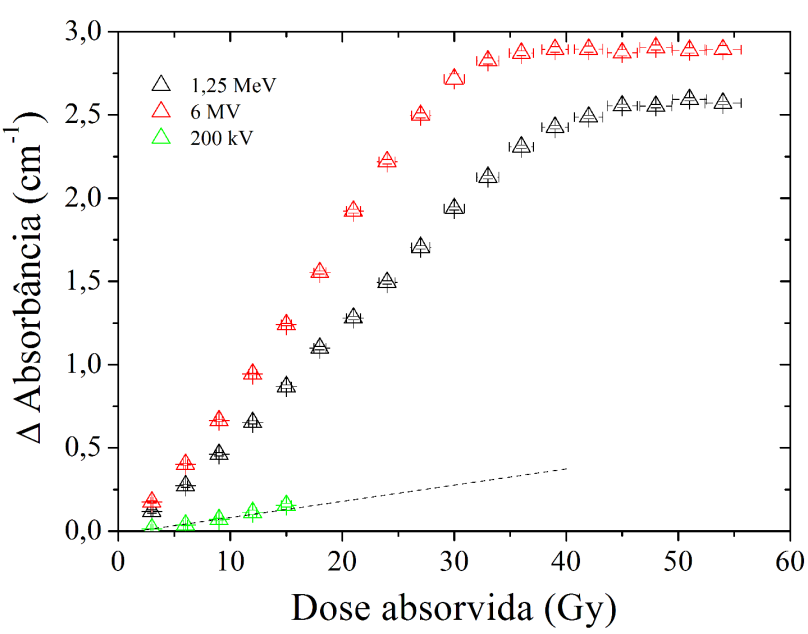

(a)

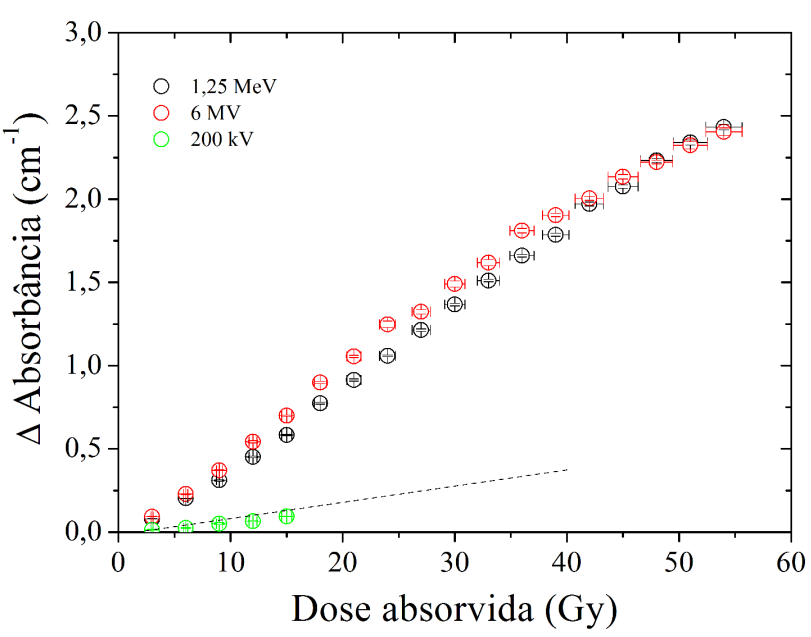

(b)

Figura 3.12. Respostas relativas em absorbância versus dose absorvida para diversas energias de feixes de fótons para irradiação dos FXG (a) original e (b) proposto. 


\subsubsection{Resolução da resposta em dose absorvida do FXG}

A resolução em dose absorvida do FXG original já havia sido estimada em 0,2 Gy [143] e corrobora com os dados do espectrofotômetro obtidos com os dosímetros estudados nesta pesquisa. As resoluções máximas em dose absorvida apresentadas pelos dosímetros FXG original e proposto foram $0,10 \pm 0,01 \mathrm{~Gy}$, para a técnica espectrofotométrica, e 0,50 \pm 0,02 Gy, para a técnica $C C D$. Porém, tais resoluções máximas foram apenas factíveis para doses absorvidas $<10 \mathrm{~Gy}$, devido à absorbância de cada amostra irradiada. Resoluções em torno de 1,0 Gy foram obtidas com ambos os dosímetros para o intervalo restante de dose absorvida, Figura 3.13, e mostramse suficientes para uma adequada dosimetria de irradiação do sangue.

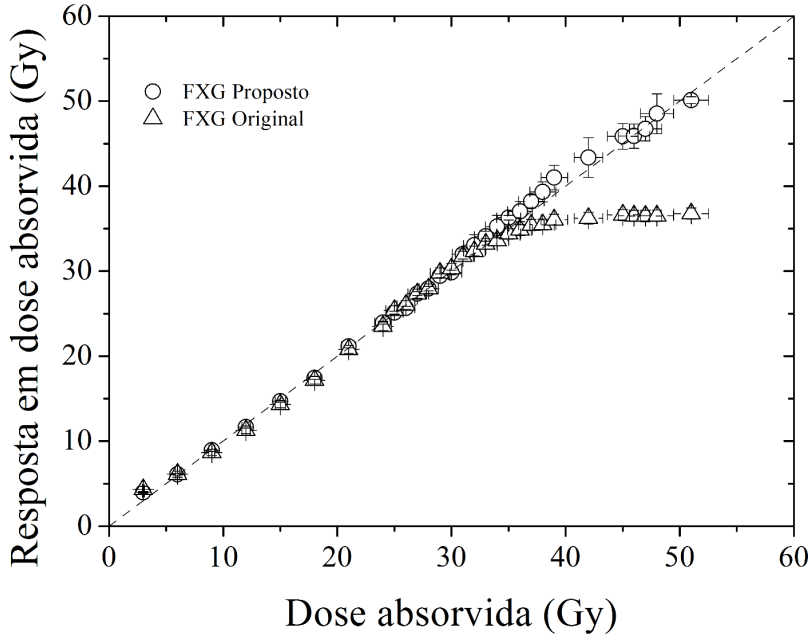

(a)

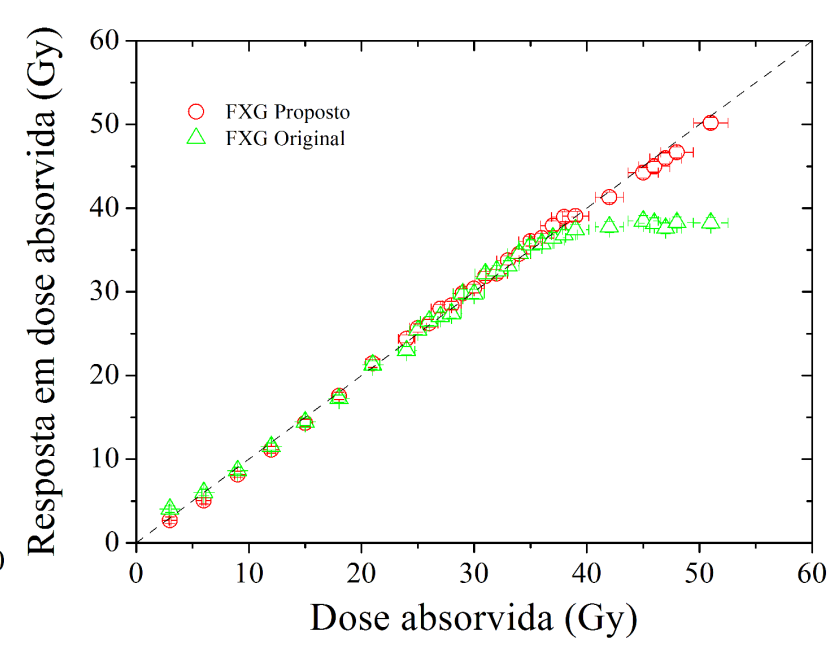

(b)

Figura 3.13. Curvas de calibração exibindo resoluções de até 1,0 Gy para as técnicas (a) espectrofotométrica e (b) CCD para os dosímetros FXG original e proposto.

Apesar da resolução em dose absorvida obtida pelo sistema $C C D$ ser 5 vezes menor aquela obtida com o espectrofotômetro, a linearidade em resposta para ambas as técnicas de aquisição foi similar $(r=0,995$, para o procedimento com o espectrofotômetro e $r=0,997$, para o com sistema $C C D$ ). Contudo, embora a resolução em dose tenha sido inferior para aquisições com o $C C D$, esta técnica permite a análise da distribuição espacial da dose absorvida em um plano, de maneira rápida e simples. Além disso, de acordo com a metodologia disposta na subseção 2.1.2, determinou-se uma resolução espacial para o sistema dosimétrico ("FXG + sistema de aquisição de imagens $\left.C C D^{\prime \prime}\right)$ próxima de 0,44 \pm 0,07 mm [197]. Dessa maneira, enquanto o 
espectrofotômetro é recomendado quando uma maior resolução em dose absorvida é desejada, o sistema $C C D$ é mais indicado quando elevada resolução espacial na inferência de dose absorvida é necessária.

\subsubsection{Efeitos devido ao armazenamento do FXG}

Idealmente, a dosimetria FXG deve ser realizada no mesmo local de preparo do dosímetro, devido à sua instabilidade decorrente do armazenamento [118]. Contudo, considerando-se a rotina de um banco de sangue, os comportamentos do dosímetros FXG original e proposto foram estudados para diferentes tempos de estocagem.

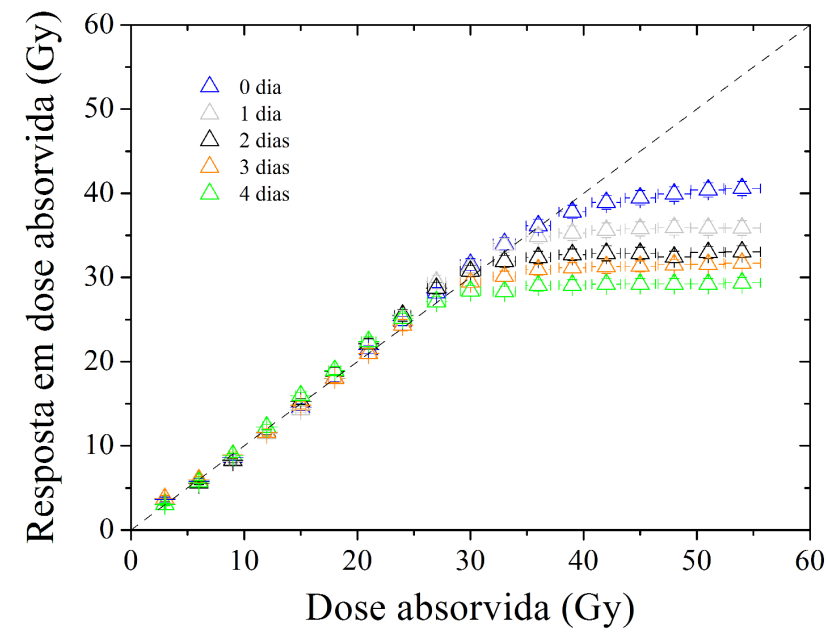

(a)

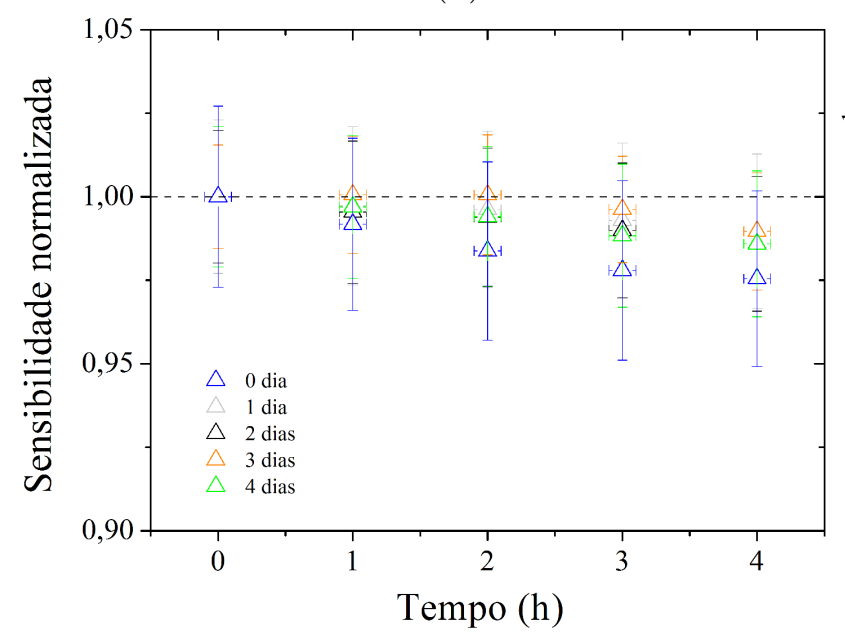

(c)

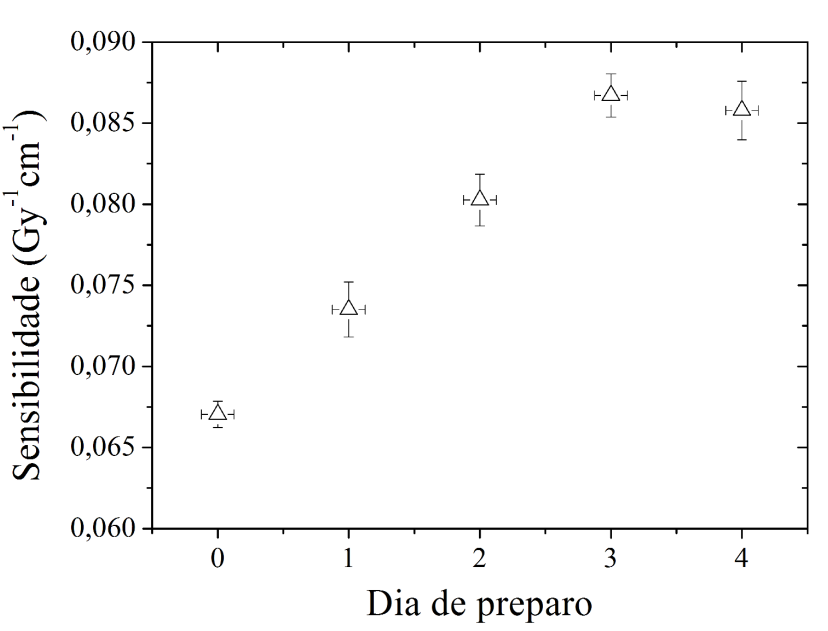

(b)

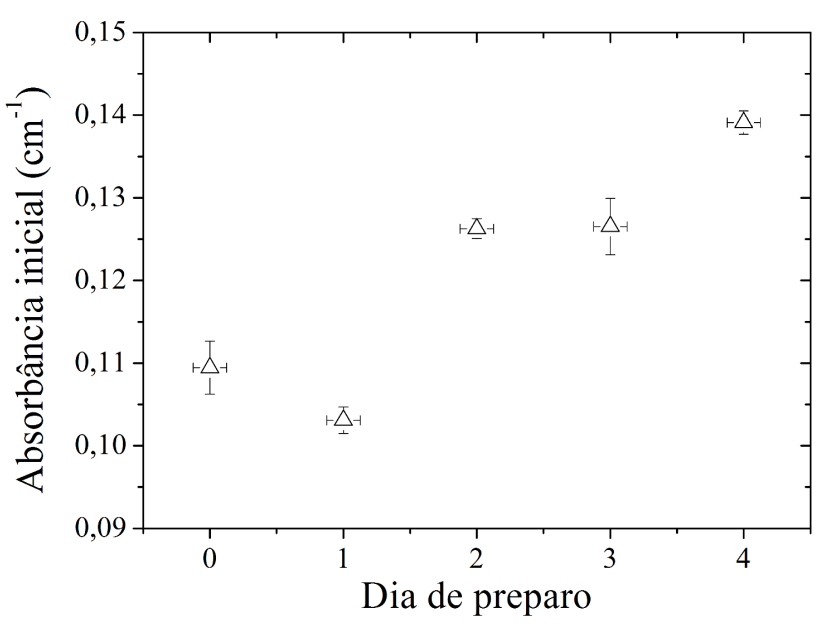

(d)

Figura 3.14. Características do dosímetro FXG original em função do tempo de armazenamento em termos de (a) linearidade, (b) sensibilidade, (c) desvanecimento do sinal após a irradiação e (d) absorbância inicial. 
A Figura 3.14 exibe os comportamentos do FXG original em função dos dias de armazenamento. Conforme pode ser notado em (a), o aumento de dias fez com que a resposta do FXG saturasse mais rapidamente $($ de $\approx 39$ para $\approx 30$ Gy, para 0 e 4 dias de estocagem, respectivamente), entretanto sua sensibilidade aumentou em quase $50 \%$, gráfico (b). O desvanecimento do sinal tendeu a diminuir conforme o aumento do tempo de armazenamento, Figura 3.14(c), o que pode ser em virtude da maioria dos íons ferrosos já ter sido oxidada. Já a absorbância inicial teve seu valor aumentado com os dias de armazenamento, gráfico $(\mathrm{d})$, devido à presença principalmente de matéria orgânica (gelatina) na solução, a qual acelerou o processo de oxidação em decorrência do aumento da concentração de radicais livres.

Os comportamentos do FXG proposto em função do tempo de armazenamento encontram-se ilustrados na Figura 3.15. Diferentemente do FXG original, a receita proposta não apresentou alterações tão significativas em sua resposta em função do tempo de estocagem, gráficos (a) e (b). Isso acaba sendo uma característica de interesse prático, pois permite a utilização de dosímetros estocados ao longo de alguns dias sem a aplicação de fatores de correção. O desvanecimento do sinal e a absorbância inicial também mostraram menores dependências com o tempo de estocagem, gráficos (c) e (d), comparativamente ao FXG original. Tais comportamentos podem ser explicados pela maior concentração de Xilenol na receita proposta, que, como visto pelos resultados dispostos na sub-seção $\mathbf{3 . 1 . 5}$, tendeu a estabilizar o dosímetro.

\subsubsection{Análise estatística}

\subsubsection{Teste ANOVA}

O objetivo da técnica de análise de variância ( $A N O V A)$ aplicada neste trabalho foi o de testar se existiam diferenças significativas entre duas ou mais médias entre as grandezas estudadas para os dosímetros FXG original e proposto. O valor do teste-F calculado para o dosímetro proposto, Tabela 3.2, foi aproximadamente 50 \% superior ao do FXG original ${ }^{8}$ e indica uma maior "adequabilidade" em termos da regressão linear para a nova receita. Além disso, os valores-F calculados para ambos os dosímetros foram duas ordens de grandeza superiores ao valor crítico tabelado em

\footnotetext{
${ }^{8}$ Como o dosímetro original não é linear para todo o intervalo de doses, considerou-se o intervalo [3;39] Gy para os cálculos.
} 


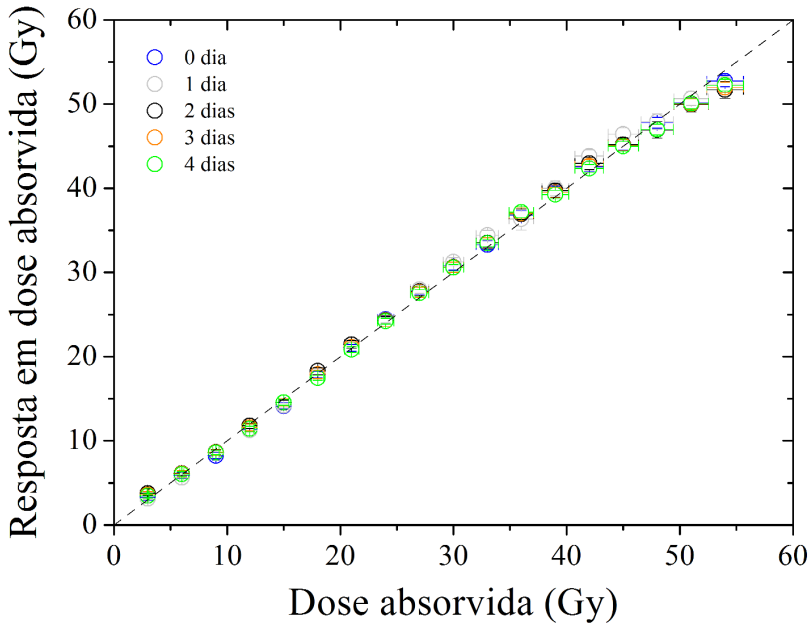

(a)

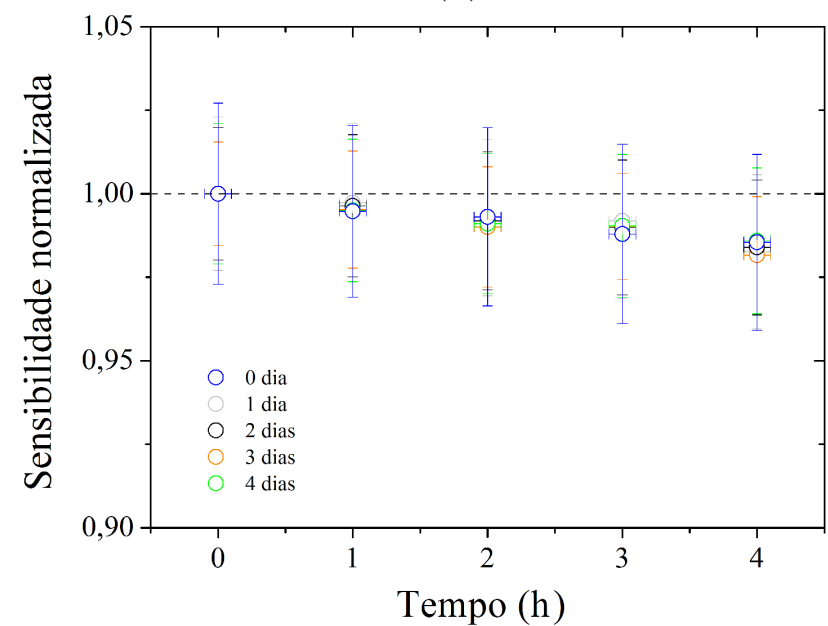

(c)

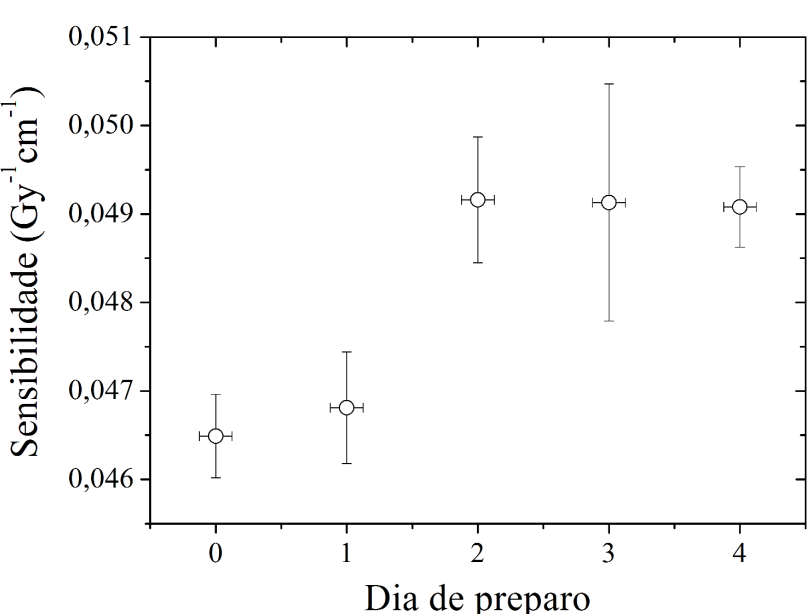

(b)

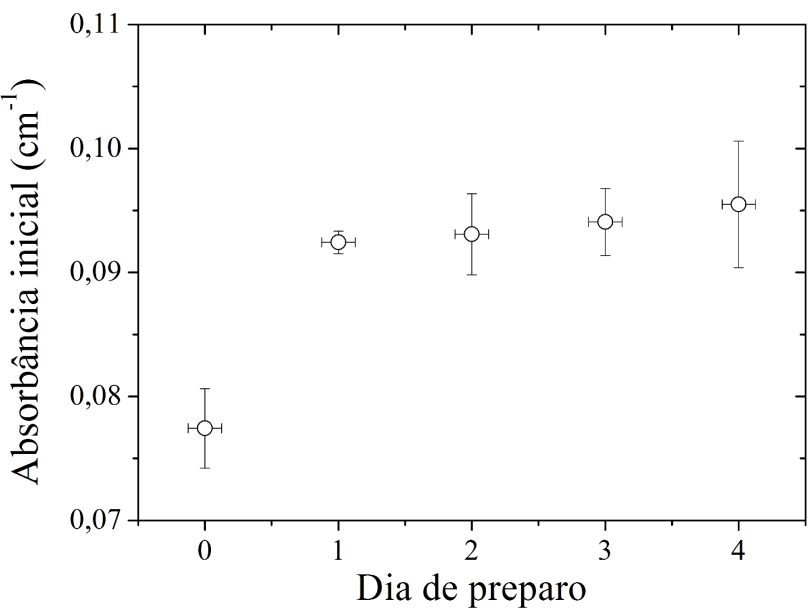

(d)

Figura 3.15. Características do dosímetro FXG proposto em função do tempo de armazenamento em termos de (a) linearidade, (b) sensibilidade, (c) desvanecimento do sinal após a irradiação e (d) absorbância inicial.

um nível de confiança de $95 \%$ (valor-F $=4,4940$ ), indicando que existe uma forte evidência de linearidade para as curvas.

\subsubsection{Erro Padrão de Previsão, SEP}

A grande vantagem do $S E P$ é que este parâmetro independe do intervalo de valores considerados durante os cálculos. Diferentemente da estatística ANOVA e do coeficiente de correlação linear, $r$, o SEP se baseia em cálculos considerando apenas a variabilidade das diferenças entre os valores inferidos e os de referência.

Considerando as medidas realizadas com o espectrofotômetro, os valores dos 
Tabela 3.2. Análise estatística para as curvas de calibração para os dosímetros FXG original e proposto.

\begin{tabular}{l||c}
\hline Dosímetro & teste-F \\
\hline FXG Original & 5075,47 \\
FXG Proposto & 7696,58 \\
\hline
\end{tabular}

SEP's variaram de 2,19 até 4,42\% (doses entre [24;54] Gy) para o dosímetro proposto, em contraste às variações de 2,55 até 3,65\% para o dosímetro original (doses entre [24;39] Gy). Para os mesmos intervalos de doses absorvidas citados, os SEP's obtidos com o sistema $C C D$ variaram de 2,12 até $3,29 \%$ e de 2,00 até $3,76 \%$ para os dosímetros proposto e original, respectivamente. Em geral, o SEP do dosímetro proposto, para ambas as técnicas, foi menor que o obtido para o dosímetro original e menores do que os valores limites esperados para as incertezas das doses absorvidas $(<5 \%)$ protocolados pela ICRU $44[212]$.

\subsubsection{Coeficiente de correlação linear}

Para o FXG original, os valores dos coeficientes de correlação linear $(r)$ considerando curvas de calibração médias ( $\Delta \mathrm{A}$ versus dose absorvida), foram de 0,998 e 0,996, para o espectrofotmetro e para o sistema de aquisição $C C D$ (canal verde), respectivamente. Já para o FXG proposto, os valores de $r$ foram de 0,998 e 0,996 (canal vermelho), respeitando a ordem já citada. Esse valores representam que 99,8 $\% ; 99,7 \%$ ou $99,6 \%$ da variabilidade de $\Delta \mathrm{A}$ é causada pela dose absorvida. Na verdade, $r$ é uma medida não apenas do nível de correlação entre essas duas grandezas, mas também das incertezas que podem ser inferidas com as curvas de calibração.

\subsubsection{Análise dos resíduos}

A fim de investigar a adequabilidade do modelo de regressão linear com base nos resíduos, foi feito o gráfico da Figura 3.16. Por meio deste gráfico, os valores dos resíduos foram exibidos em função da dose absorvida nominal (valor de referência obtido por CI calibrada), cujo comportamento pode revelar se existe ou não uma relação linear entre as grandezas estudadas. Por exemplo, se os pontos do gráfico formassem uma parábola, isso seria indicativo de que termos de segundo grau seriam 
necessários para o adequado ajuste da curva. Conforme os resultados obtidos, foi possível perceber duas áreas visivelmente distintas nas respostas dos dosímetros: um intervalo sublinear (abaixo de 0,0), para doses entre $\approx 5$ e 20 Gy, seguida de outro supralinear, $\approx 20$ a 45 Gy. Essas variações não apresentaram uma tendência significativa e mostram resíduos variando em uma distribuição aleatória ao redor do valor 0,0 Gy. Um fato que merece destaque é que nenhum dos componentes da receita $\left(\mathrm{FeSO}_{4}\right.$, gelatina, $\mathrm{H}_{2} \mathrm{SO}_{4}, \mathrm{XO}$ e $\left.\mathrm{NaCl}\right)$ pareceu influenciar consideravelmente o comportamento dos resíduos. Além disso, os gráficos exibiram resíduos não maiores do que \pm 2 Gy e indicam adequabilidade do ajuste dos dados.

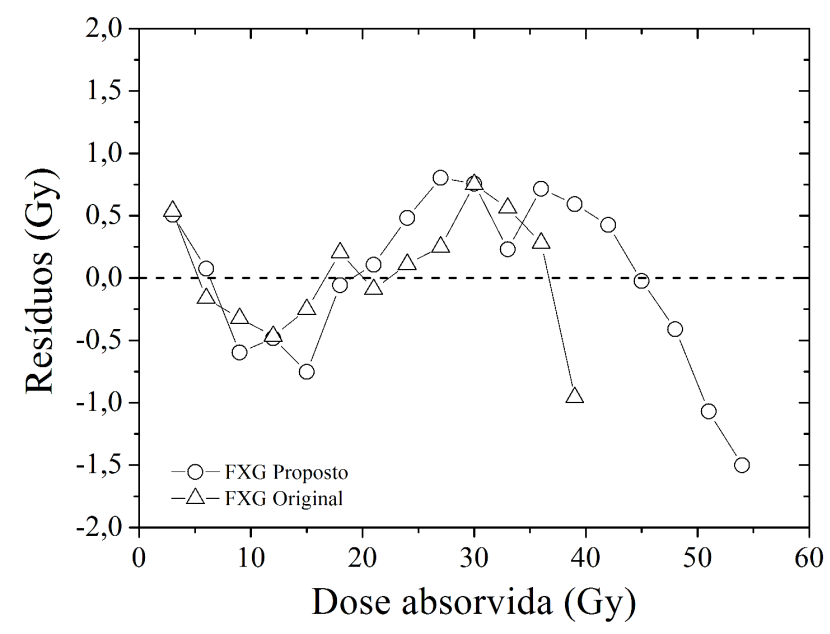

(a)

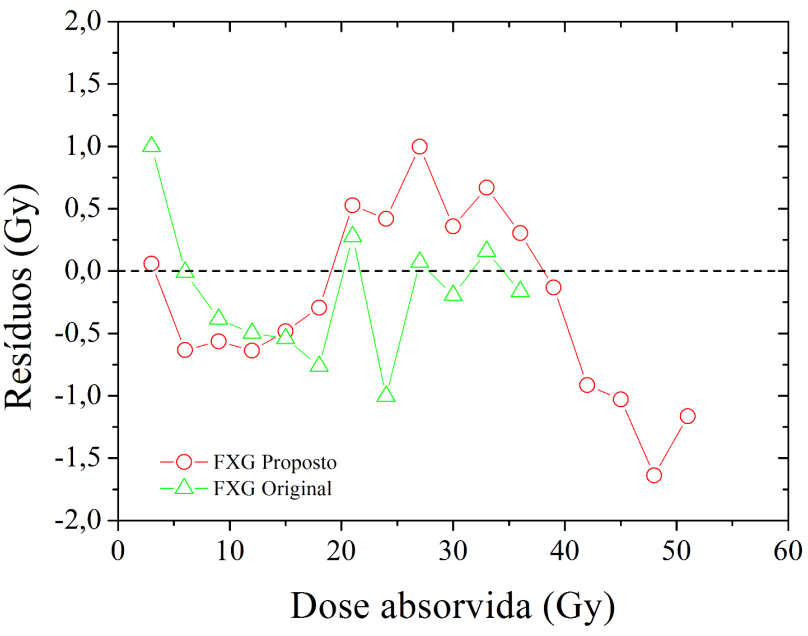

(b)

Figura 3.16. Gráfico de resíduos versus dose absorvida (valores estimados) para os dosímetro original e proposto considerando as técnicas (a) espectrofotométrica e (b) $C C D$.

\subsection{Dosimetria do irradiador específico de sangue}

Nas décadas de 1970 e 1980, os fabricantes dos irradiadores de sangue forneciam os valores da dose absorvida mensurados apenas na presença de ar, isto é, sem objetos simuladores (OS's). Isso resultava em tempos de irradiação que proporcionavam doses absorvidas menores do que as prescritas, comparativamente com o vasilhame totalmente preenchido com sangue [5]. Assim, diferentemente do artigo de VANDANA et al [242], os experimentos aqui realizados para a dosimetria do irradiador específico de sangue levaram em consideração OS's em todo o volume da irradiação. Isto parece mais adequado visto que em uma rotina diária, as irradiações têm maior 
probabilidade de ocorrerem com o vasilhame todo preenchido de bolsas de sangue. Além disso, a utilização de OS's na dosimetria vai ao encontro com as recomendações da ICRU [209].

Para irradiadores específicos de sangue rotacionários, como as bolsas de sangue são expostas à radiação enquanto todo o volume gira na frente da fonte estacionária, distribuições não uniformes da dose absorvida no volume irradiado podem ocorrer [243]. A homogeneidade da distribuição depende do número de fontes radioativas, de suas dimensões, da sua distância fonte-volume alvo, da sua posição em relação ao volume irradiado e da rotação do vasilhame (velocidade e tempo). De fato, as não uniformidades das distribuições das doses absorvidas nos equipamentos comerciais podem proporcionar volumes que recebem doses menores do que as prescritas e quanto maior a taxa de dose oferecida pela fonte, maior deve ser a frequência de rotação do volume irradiado a fim de diminuir a inomogeneidade devido à rotações incompletas.

O conhecimento da distribuição da dose absorvida permite aos médicos/físicos do estabelecimento decidirem se a irradiação feita no sangue é aceitável ou não. Assim, o mapeamento espacial das doses absorvidas, independentemente se ocorre em irradiador específico ou por um equipamento de teleterapia, é o primeiro passo para garantir que o processo de irradiação está sendo conduzido adequadamente, já que demonstra se a dose prescrita e sua distribuição está sendo entregue corretamente.

\subsubsection{Caracterização teórica dos dosímetros e objetos si- muladores de sangue}

Ao se empregar a teleterapia para a irradição de sangue, normalmente utilizamse dois campos paralelos e opostos com material simulador capaz de proporcionar as condições de equilíbrio eletrônico (build-up) e espalhamento. Em geral, esse material simulador possui espessuras entre 5 e $10 \mathrm{~cm}$, dependendo da energia da radiação, e é constituído de água ou acrílico. Com a finalidade de ser empregado como um material simulador, e estando de acordo com as recomendações da ICRU No. 44 [212], os coeficientes de atenuação linear do objeto simulador e do material simulado podem diferir, no máximo, em $\pm 1 \%$ para o intervalo de energias de interesse ${ }^{9}$ para

\footnotetext{
${ }^{9} \mathrm{~A}$ diferença percentual de $1 \%$ é adotada na Radioterapia, contudo, em Radiodiagnóstico, tal diferença apresenta um intervalo de aceitação de até $5 \%$.
} 
não acarretar em incertezas maiores do que $5 \%$ na dose absorvida.

Na Figura 3.17, encontram-se os coeficientes de atenuação mássicos, $(\mu / \rho \mathrm{em}$ $\mathrm{cm}^{2} / \mathrm{g}$ ), obtidos do sítio eletrônico do NIST [215], para diversos materiais de interesse prático, os quais foram normalizados para os coeficientes de atenuação mássicos do sangue. Como pode ser notado, tanto a água quanto os dosímetros Fricke (solução aquosa) e FXG são materiais que apresentam $\mu / \rho$ próximos aos do sangue, para a faixa de energia em questão. Ambos os dosímetros apresentam essa característica justamente por serem quase que totalmente constituídos por água (> 99 $\%$ e $\approx 95 \%$ em massa, respectivamente), o que assegura interações análogas com aquelas do sangue. Dessa forma, apesar do FXG proposto apresentar $\mu / \rho$ 's mais distantes daqueles do sangue, quando comparados ao dosímetro Fricke por exemplo, suas diferenças são menores do que 1 \%, sendo totalmente aceitável como material equivalente. Isso garante que o FXG, além de ser um dosímetro propriamente dito, é capaz de se comportar como um OS para irradiações que envolvam o sangue, mostrando-se mais adequado do que outros materiais, usualmente empregados como sangue equivalente, tais como o poliestireno [4-6, 92, 95, 212, 213].

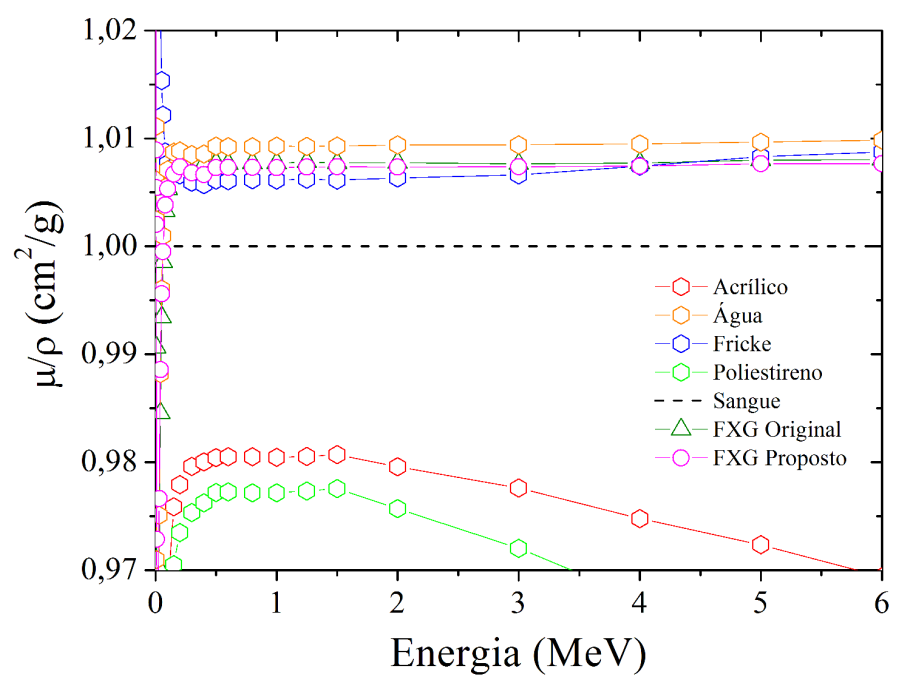

Figura 3.17. Coeficientes de atenuação mássicos, $\mu / \rho$, para diferentes materiais de interesse radiológico normalizados pelos coeficientes de atenuação do sangue [215].

A irradiação de sangue também pode ser realizada utilizando-se feixes de elétrons de alta energia. A grande vantagem em se aplicar esta última técnica é a homogeneidade possível de ser adquirida em todo o volume irradiado. De acordo 
com Butson et al, exposições de 30 Gy com feixes de elétrons de $20 \mathrm{MeV}$, considerando a dose máxima em 2,8 cm, foram capazes de apresentar variações menores do que $6 \%$ em todo o volume ativo [244]. Além disso, para feixes de elétrons, os autores também defendem a irradiação por meio de um único campo, diferentemente quando se empregam campos paralelos e opostos com feixes de fótons. Apesar das vantagens destacadas, algumas limitações poderiam prejudicar a irradiação das bolsas de sangue com elétrons quando feitas em larga escala, tais como 1) a rápida deteriorização do tubo do acelerador linear, devido ao longo tempo de irradiação, 2) da rotina incompatível entre a Radioterapia e a demanda de sangue irradiado e 3) o tamanho do campo que o acelerador é capaz de fornecer para feixes de elétrons. Como o feixe acelerado possui dimensões de milímetros, campos maiores do que 25 $\times 25 \mathrm{~cm}^{2}$ normalmente não são disponíveis. Apesar dessas limitações, os materiais mais utilizados como OS's foram caracterizados em termos de seus respectivos stopping powers $(S)$,, obtidos do sítio eletrônico do NIST [215], os quais também foram normalizados para os do sangue total, Figura 3.18. Analogamente aos resultados dos coeficientes mássicos, os stopping powers da água e dos dosímetros Fricke e FXG apresentaram maior similaridade daqueles exibidos pelos sangue total. Novamente, ambos apresentaram diferenças menores do que $1 \%$, com destaque para o dosímetro FXG proposto, o qual apresentou diferenças em torno de 0,5\% para a feixe energética considerada. Assim como no caso de interações com fótons, o FXG mostrou-se radiologicamente sangue equivalente em irradiações envolvendo elétrons.

\subsubsection{Dosimetria de referência}

Para o levantamento de curvas de isodoses em aplicações dosimétricas comumente utilizam-se de câmaras de ionizações (CI) ou arranjos de dosímetros TL's, embora os dosímetros Fricke (solução aquosa) também possam ser empregados [214,245]. Além da impossibilidade de se utilizarem CI's em irradiadores de sangue do tipo rotativo, os demais métodos (TLD e Fricke) podem resultar em mapeamentos de baixa resolução espacial, passíveis de imprecisões em regiões de altos gradientes de doses, serem limitados para doses absorvidas elevadas (> 10 Gy) e consumirem um tempo considerável de coleta de dados [187,242]. Por outro lado, o emprego do dosímetro FXG ou de filmes radiocrômicos, juntamente com o sistema de aquisição 


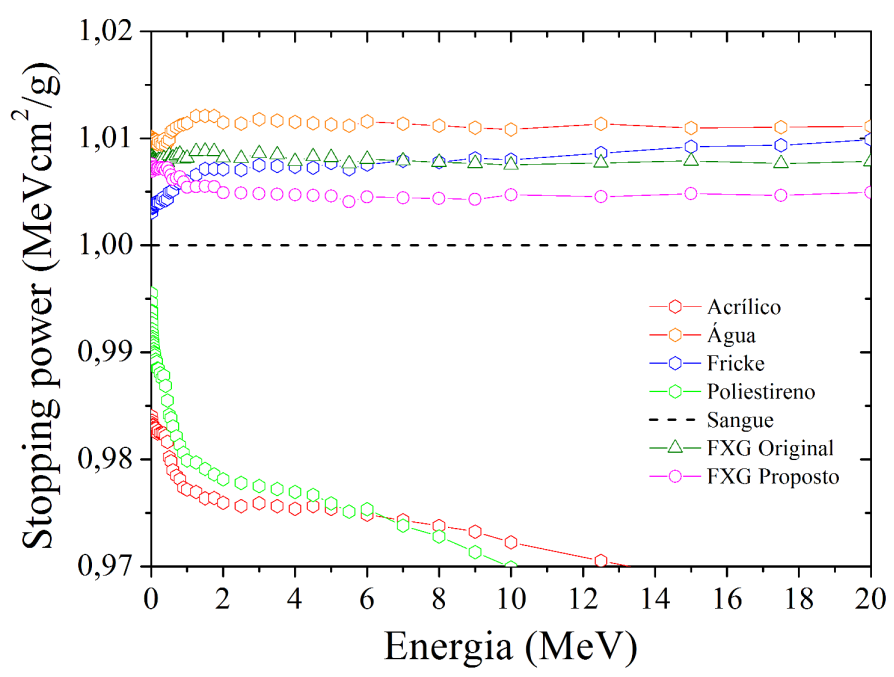

Figura 3.18. Stopping-powers, $S$, para diferentes materiais de interesse radiológico normalizados pelos $S$ 's do sangue [215].

digital $C C D$, desenvolvido pelo grupo RADIARE, permite a criação de curvas de isodoses com elevadas resoluções espaciais de maneira simples e em reduzido espaço de tempo.

A dosimetria de referência quanto à distribuição da dose absorvida foi realizada utilizando-se dosímetros termoluminescentes (TL's), por meio da interpolação das leituras de cada pastilha, e o filme EBT2. Tanto os TL's quanto os filmes radiocrômicos já vêm sendo propostos ou utilizados para a dosimetria da irradiação de sangue $[4-6,8,92,95,212,213,242,246]$. A calibração para cada dosímetro foi feita com o ${ }^{60} \mathrm{Co}$, devido à facilidade de posicionamento e liberação das doses absorvidas. Apesar dos dosímetros de referência terem sido calibrados no ${ }^{60} \mathrm{Co}$, é sabido que a dependência energética tanto para o LiF quanto para o filme é aceitável entre feixes primários de ${ }^{60}$ Co e de ${ }^{137} \mathrm{Cs}[211,247]$.

As principais considerações que devem ser feitas quanto ao uso dos filmes EBT2 da GAFCHROMIC ${ }^{\mathrm{TM}}$ na dosimetria, seja da irradiação de sangue ou não, diz respeito à resposta desse dosímetro para a luz ultravioleta e riscos/contaminações no filme. Como as leituras são realizadas no espectro visível, riscos e contaminações, tais como resquícios de sangue e impressões digitais, podem afetar a absorbância lida. Além disso, deve-se fazer um controle prévio do filme, pois já foi reportado que os filmes GAFCHROMIC $^{\text {TM }}$ podem apresentar uma não uniformidade em sua resposta de até $12 \%$, ao considerar uma folha de filme [248]. 
Após as irradiações no irradiador específico, os mapas das doses absorvidas percentuais foram construídos interpolando as leituras de cada dosímetro TL e por meio da aquisição $C C D$ e do processamento das imagens do filme radiocrômico. Ambos foram representados em escala de cores, conforme mostram as Figuras 3.19(a) e (b). A partir delas, é possível perceber o considerável gradiente de doses absorvidas que pode existir entre o centro e a periferia do volume alvo do irradiador. Verticalmente, a variação percentual máxima notada foi $\approx 33 \%$ em relação à dose central, enquanto horizontalmente, essa diferença foi em torno de $\approx 36 \%$.

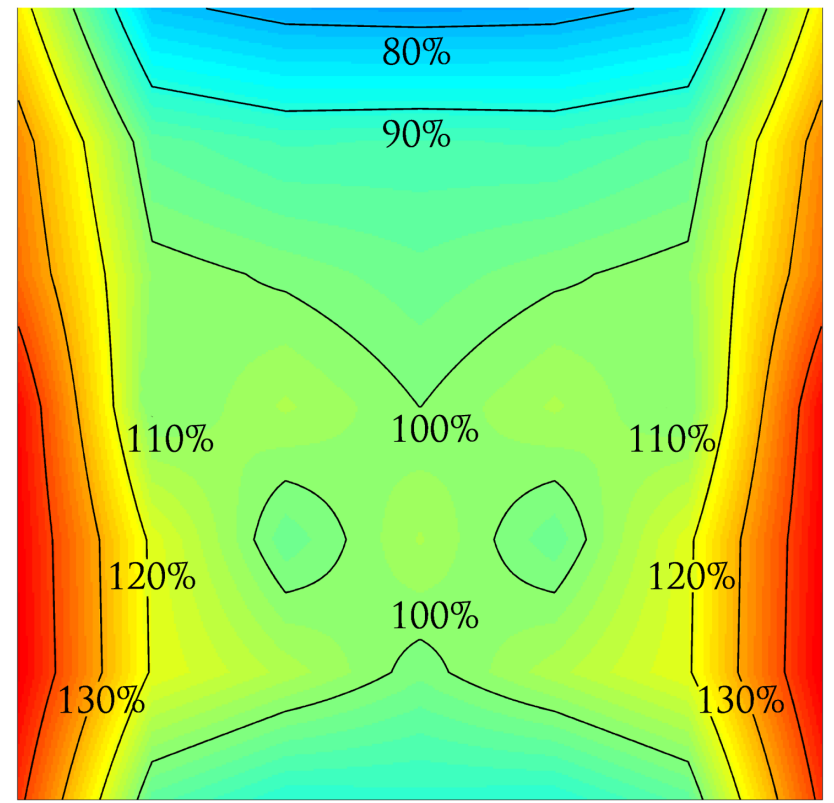

(a)

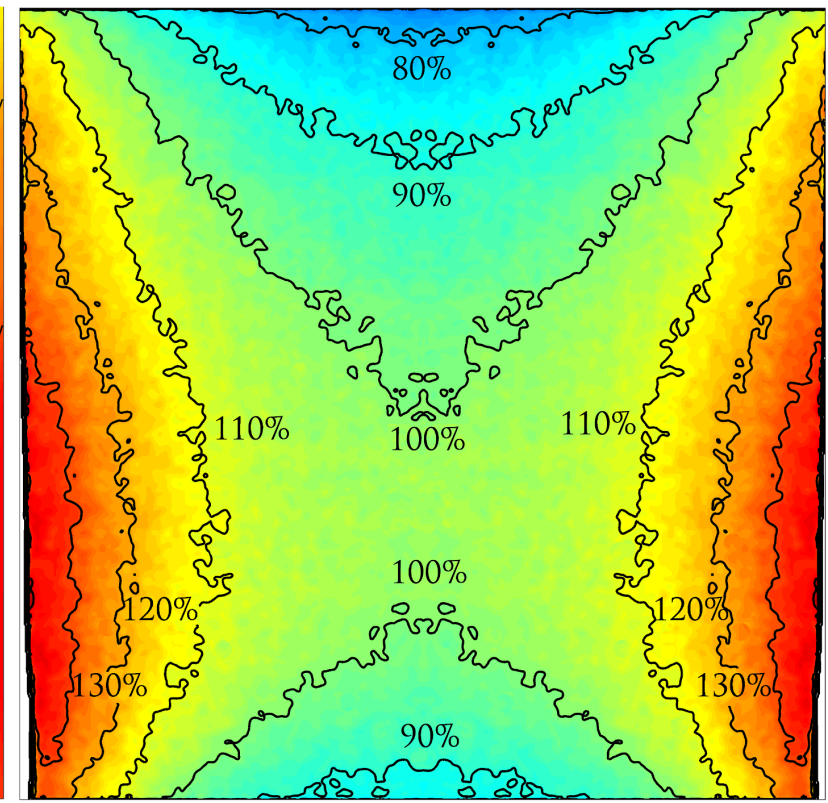

(b)

Figura 3.19. Porcentagens de taxas de doses no objeto simulador de poliestireno, determinadas após calibração no ${ }^{60} \mathrm{Co}$ para (a) os TL's e (b) o filme.

Em uma irradiação de sangue, de acordo com o que já foi exposto no Capítulo 1, preconiza-se uma dose absorvida de pelo menos 25 Gy para se garantir a qualidade do hemocomponente irradiado e evitar a principal doença a qual se destina o uso da radiação ionizante, a DECH-AT. Nesse sentido, os valores mais preocupantes são os exibidos na parte superior de cada mapa, que oscilam entre 77 e $81 \%$ daquele exibido no centro, correspondendo a 19,25 e 20,25 Gy, respectivamente. Esse comportamento deve ser levado em consideração quando se irradia um grande volume de sangue, já que, dependendo do tempo programado, nem todas as bolsas receberão o mínimo de 25 Gy. 
A dosimetria fornecida pelo fabricante do irradiador também foi adotada como de referência e é exibida na Figura 3.20. Conforme pode ser visto nos três mapas de doses mostrados nesta seção, todas distribuições corroboram entre si tanto quali quanto quantitativamente, de acordo com as limitações de cada método de dosimetria.

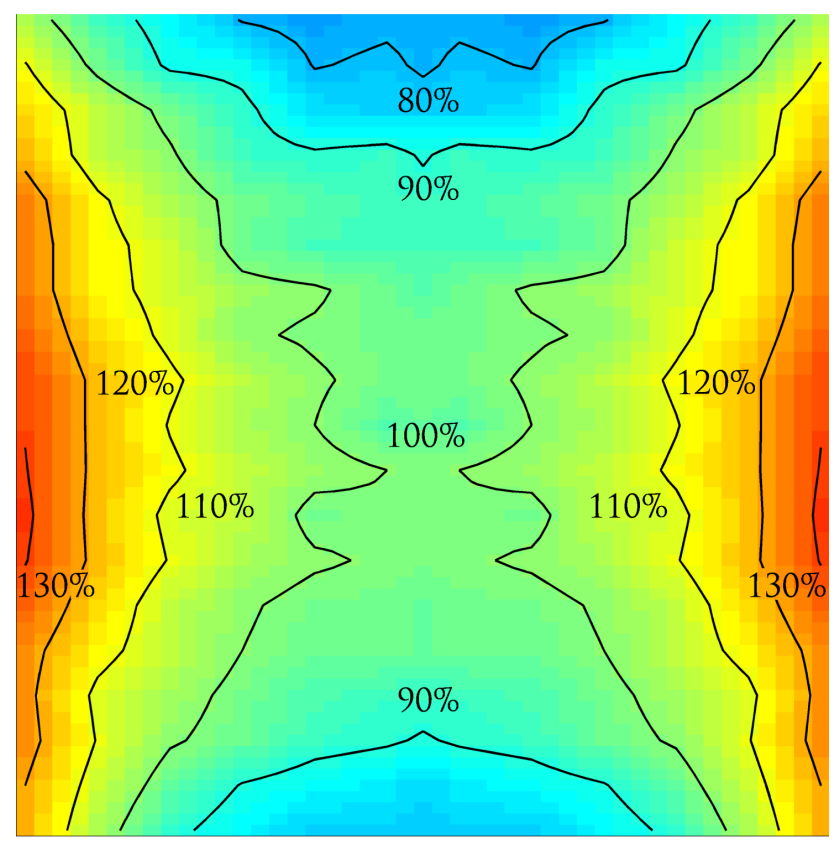

Figura 3.20. Distribuição das doses absorvidas percentuais fornecidas pelo fabricante do irradiador Gammacell $3000^{\circledR}$.

\subsubsection{Comparação das curvas de isodoses obtidas pelo FXG com as de referência}

Atualmente, já existem sistemas dosimétricos comerciais que podem ser empregados na rotina da irradiação de sangue constituídos de dosímetros TL's, filmes radiocrômicos ou sensores eletrônicos (MOSFET). Um dos mais utilizados é o que emprega filmes radiocrômicos devido as vantagens como resolução espacial e sensibilidade que tal metodologia proporciona. Além disso, como mencionado no Capítulo 1, também já foi proposto um dosímetro químico aquoso composto de iodeto de potássio $(\mathrm{KI})$ e iodato de potássio $\left(\mathrm{KIO}_{3}\right)$ para a dosimetria da irradiação de sangue que apresenta linearidade até 60 Gy [249]. No citado dosímetro, a dose deve ser inferida através de leituras de absorbância no comprimento de onda do UV (352 $\mathrm{nm}$ ), o que pode ser uma limitação prática, pois nem todos os espectrofotômetros 
possuem esse tipo de radiação. Além disso, como uma constatação visual sobre a resposta desse dosímetro não pode ser realizada, uma análise qualitativa imediata não pode ser aferida, o que pode prejudicar a rotina. Fora isso, o dosímetro de iodeto é aquoso e dessa maneira a distribuição espacial da dose absorvida torna-se dificultosa, principalmente quando comparada com a obtida através do FXG. Aliás, a densidade de massa do FXG $\left(\rho_{F X G}=1,05 \mathrm{~g} / \mathrm{cm}^{3}\right)$ mostra-se, também, mais próxima à do sangue $\left(\rho_{S}=1,06 \mathrm{~g} / \mathrm{cm}^{3}\right)$ [250] quando comparada com a do dosímetro feito com iodeto $\left(\rho_{I}=1,09 \mathrm{~g} / \mathrm{cm}^{3}\right)$. Por fim, o dosímetro de iodeto possui incerteza máxima associada à uma dose de 25 Gy em torno de $6 \%$, devido à dificuldade em se determinar o valor-G dessa solução. As incertezas máximas calculadas para o FXG não superaram esse limite $(\approx 5 \%)$.

Para as leituras do FXG proposto no sistema $C C D$ digital, adotou-se o canal vermelho durante o processamento das imagens, como mencionado anteriormente, de modo a adequar sua resposta aos parâmetros da curva de calibração determinados (coeficientes angular e linear). Conforme pode ser visto nas Figuras 3.21(a) e (b), a escolha do canal influencia consideravelmente a distribuição de doses inferida. Além disso, para a aquisição dos dados no canal vermelho houve a necessidade em aumentar o número de fotos obtidas por distribuição (05 fotos), de modo a aumentar a razão sinal/ruído da imagem, o que proporcionou melhoras significativas nos mapas de isodoses, Figura 3.21(c).

Comparando-se as Figuras 3.19(a) e 3.21 é possível perceber a elevada resolução espacial nos mapas de dose que foi possível obter ao se empregar o dosímetro FXG juntamente com a técnica $C C D(\approx 0,44 \mathrm{~mm})$. Embora a resolução espacial alcançável com o uso de dosímetros TL's também seja considerada "alta" ( $\approx 1 \mathrm{~mm}$ ), ela só pode ser conseguida de maneira muito mais trabalhosa. De fato, como os cristais LiF não possuem dimensões infinitesimais como o gel, a diferenciação entre dois pontos distintos nesse último dosímetro é limitada majoritariamente pela resolução espacial do $C C D$.

Em irradiadores específicos já foram reportadas heterogeneidades para doses absorvidas no volume irradiado de 70 até $135 \%$ [4,17], o que corrobora com os intervalos obtidos dos mapas da Figura 3.22 (em geral de 75 até $135 \%$ ). Além disso, as doses absorvidas nas bordas dos mapas foram até $30 \%$ superiores as do eixo central, 


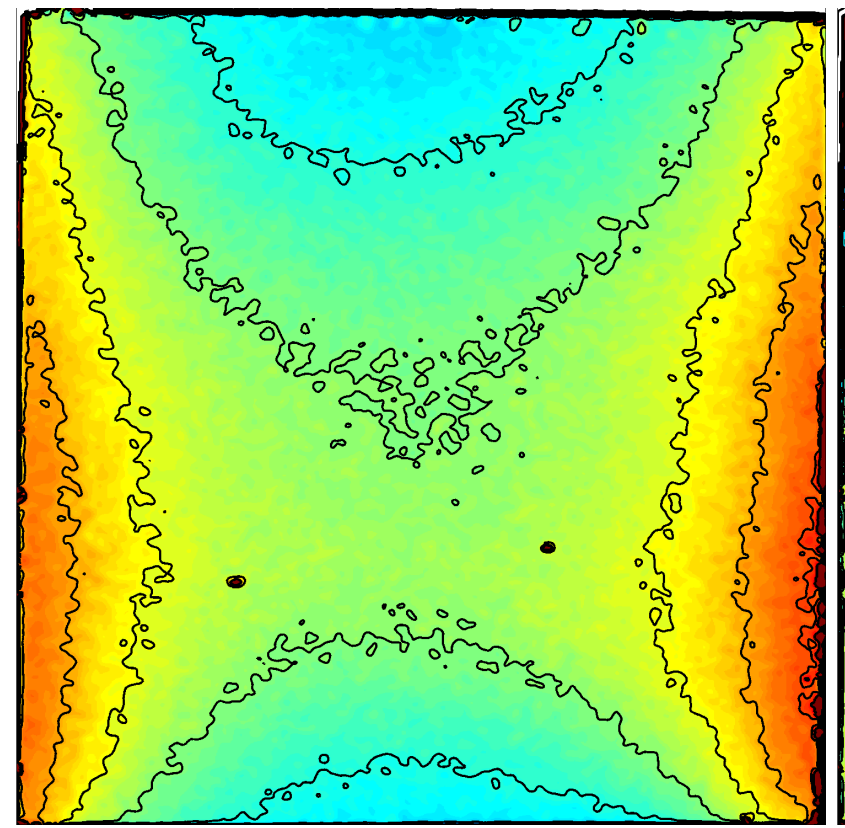

(a)

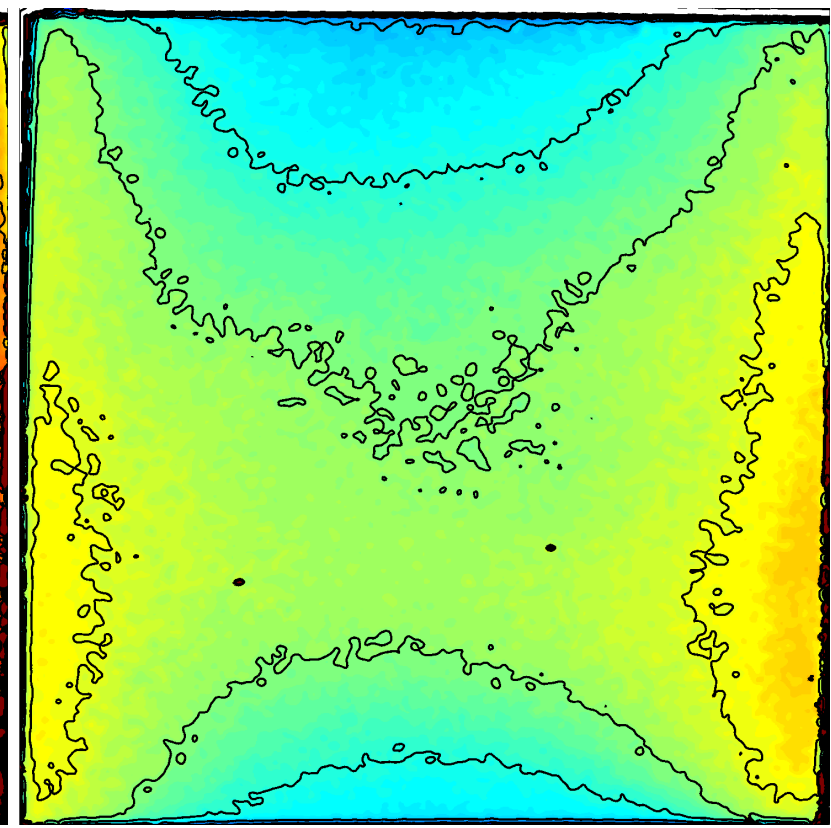

(b)

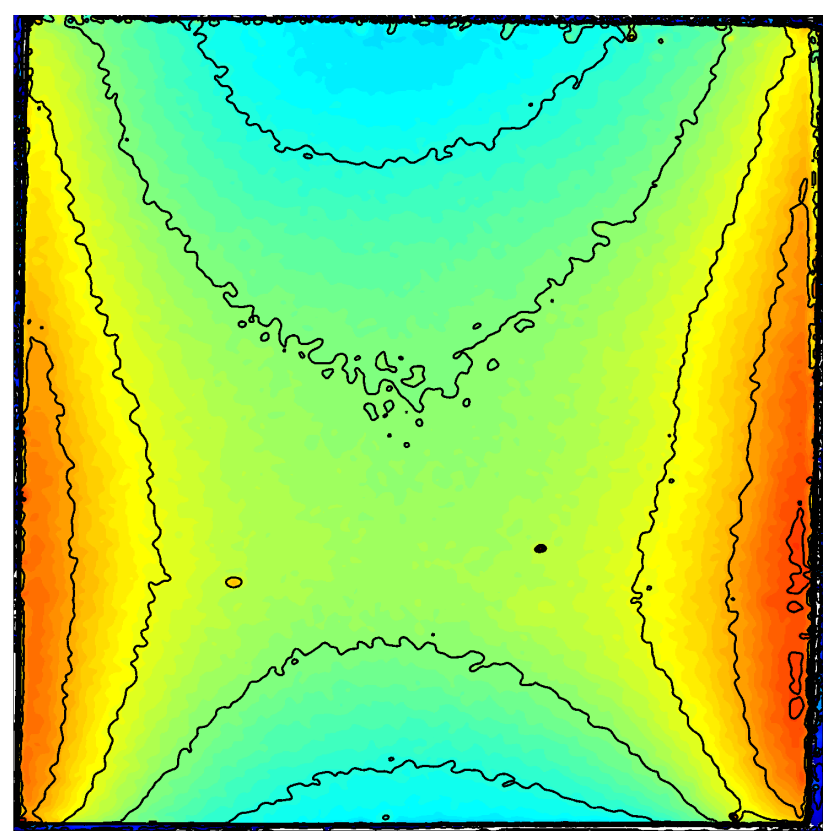

(c)

Figura 3.21. Diferenças ao se adquirir os dados pelos canais (a) vermelho e (b) verde para o FXG proposto. (c) Distribuição de doses absorvidas utilizando-se média de cinco fotos para o canal vermelho. 
sendo condizentes com os valores reportados [249]. Os mapas também mostram que a dose absorvida não é horizontalmente simétrica, exibindo diferenças em torno de $10 \%$ entre os lados direito e esquerdo, estando de acordo com outros resultados presentes na literatura $[4,251]$. Essa não simetria pode indicar uma rotação irregular do vasilhame ou um número distinto de voltas para cada lado irradiado.

Os mapas percentuais de isodoses do irradiador específico Gammacell ${ }^{\circledR} 3000$ Elan foram obtidos aleatoriamente com o dosímetro FXG proposto e respectivo OS (Figura 2.8). Os resultados estão ilustrados na Figura 3.22 em passos de $10 \%$ e sem a utilização da técnica da média dos dados (conforme descrito na sub-seção 2.4.2.1). Conforme visto, cada dosímetro apresentou regiões razoavelmente homogêneas no centro do plano em razão da rotação contínua do volume frente à fonte radioativa. Além disso, todos os dosímetros também apresentaram valores mais elevados da dose absorvida na metade inferior do volume irradiado. Este comportamento pode estar relacionado à duas possíveis razões: espalhamento dos fótons incidentes e alinhamento da fonte. Como o topo do vasilhame não possui tampa, era de se esperar que não ocorresse uma irradiação verticalmente simétrica, em virtude da diferença de espalhamento em relação à base metálica do vasilhame. Contudo, como a energia do ${ }^{137} \mathrm{Cs}$ é relativamente baixa $(0,662 \mathrm{MeV})$, o espalhamento resultante não seria o principal responsável pela distribuição das doses absorvidas obtida. De fato, a energia média dos elétrons devido às interações Compton é de aproximadamente 250 $\mathrm{keV}$ [118], considerando a teoria de aproximação de frenagem contínua (Continuous Slowing-Down Approximation - CSDA) para materiais de baixo número atômico, o que resulta em um alcance menor do que $1 \mathrm{~mm}$ [252]. Dessa forma, como o espalhamento não é o principal contribuinte para a não simetria, os dados sugerem que a fonte radioativa pode estar desalinhada do centro vertical. Contudo, mesmo que o irradiador esteja com sua fonte desalinhada, os dosímetros empregados mostram que ele ainda é capaz de irradiar sangue a níveis aceitáveis de homogeneidade.

Outra interpretação que pode ser feita a partir dos mapas de isodoses é como a distribuição percentual das doses absorvidas pode ser alterada de acordo com a orientação com que o dosímetro é inserido no compartimento de irradiação. Como o sistema dosimétrico foi colocado aleatoriamente no irradiador específico, o número de rotações em frente à fonte radioativa contribui significativamente para esse com- 


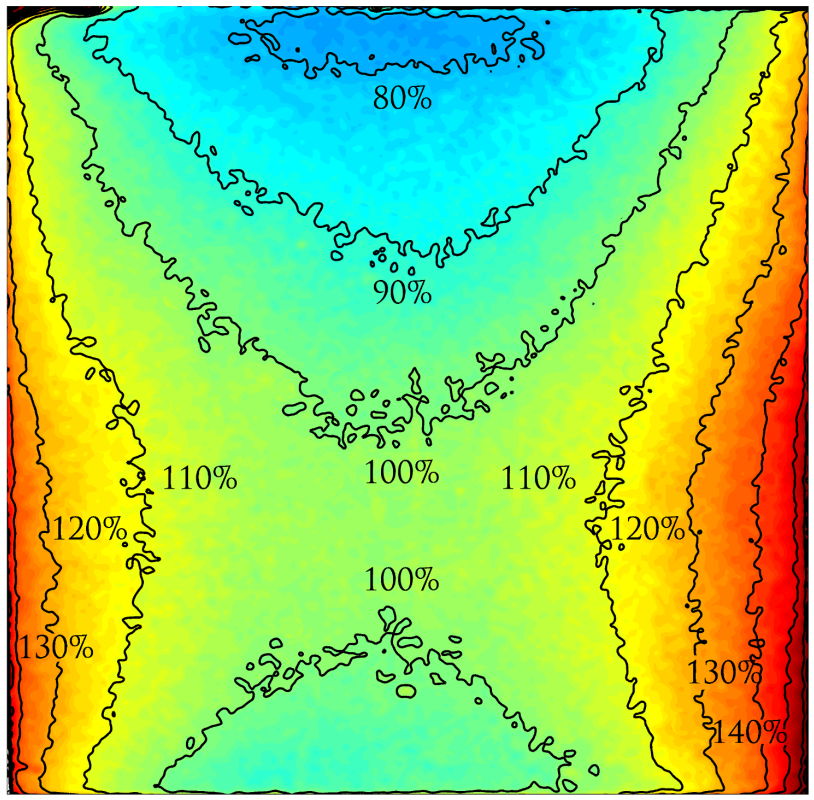

(a)

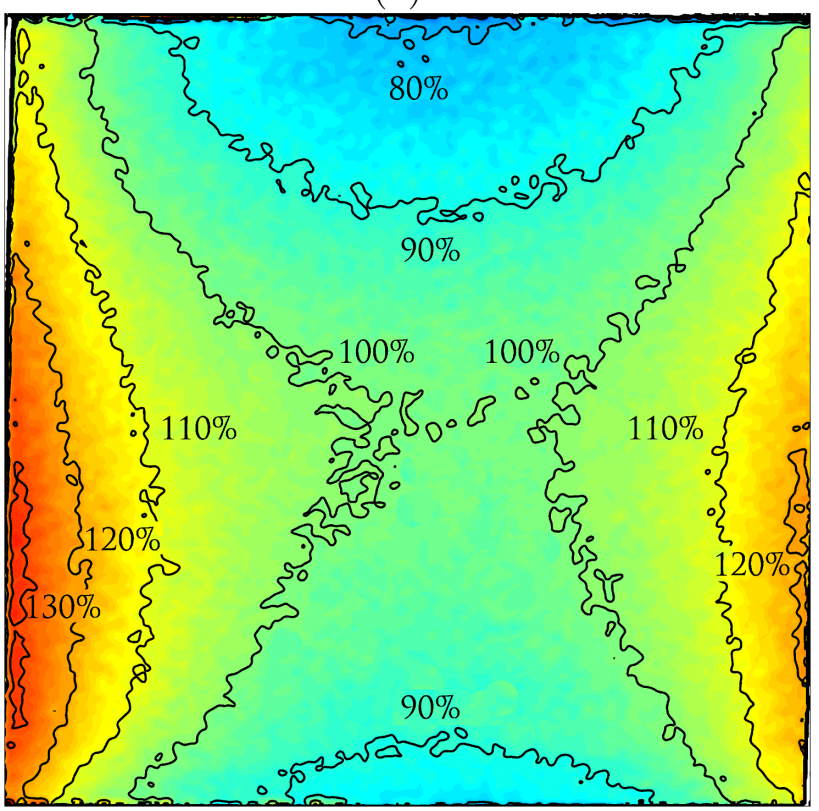

(c)

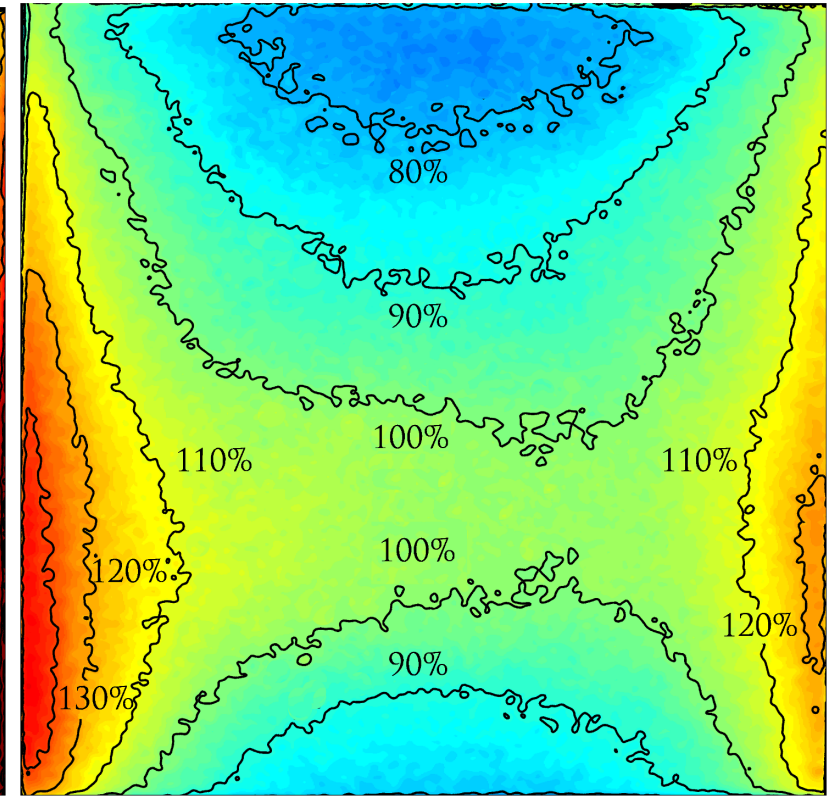

(b)

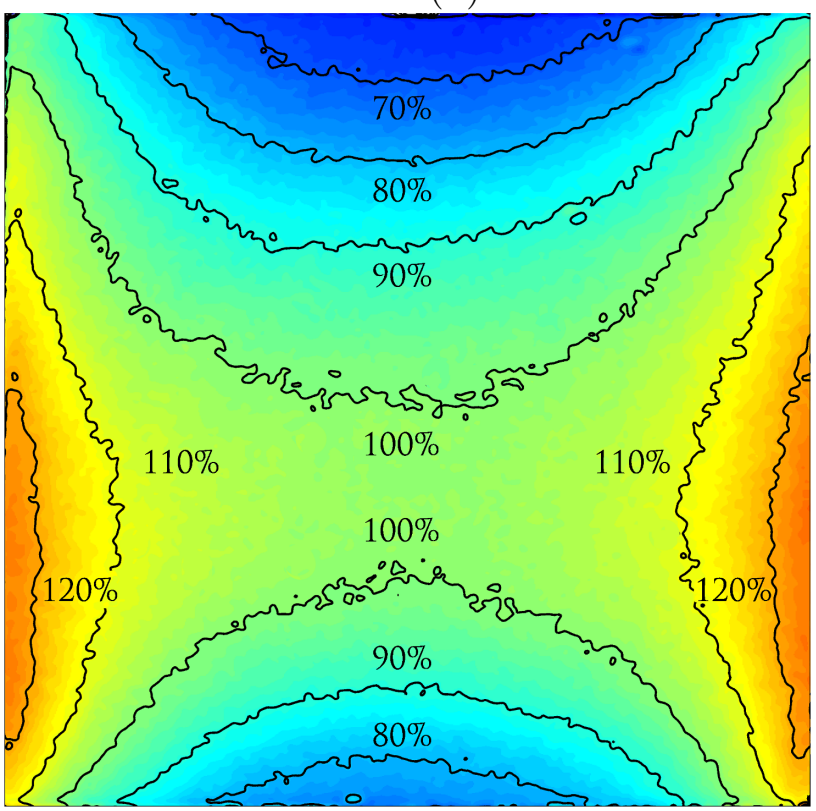

(d)

Figura 3.22. Distribuições percentuais para doses absorvidas obtidas com o dosímetro FXG proposto no irradiador específico. 
portamento, especialmente ao se considerar taxas de doses absorvidas em torno de 5 Gy/min. Neste sentido, a Figura 3.22(d) merece destaque, pois esse foi obtido tomando-se um cuidado adicional durante a irradiação. Incialmente, o dosímetro foi inserido no irradiador conforme a orientação mostrada na Figura 3.23(a) por um tempo de irradiação T. Finalizado esse tempo, o dosímetro foi retirado do irradiador e rotacionado de modo que sua orientação ficasse oposta à primeira ocasião, Figura 3.23(b), e irradiado por mais um tempo $T$. Isso resultou em uma distribuição mais simétrica, porém ocasionou uma subdosagem mais significativa nas partes superior e inferior do plano, as quais podem ser particularmente importantes durante as irradiações das bolsas de sangue, pois doses absorvidas menores do que as prescritas podem ser liberadas, o que aumentariam os riscos do desenvolvimento da DECH-AT.

(a)

(b)

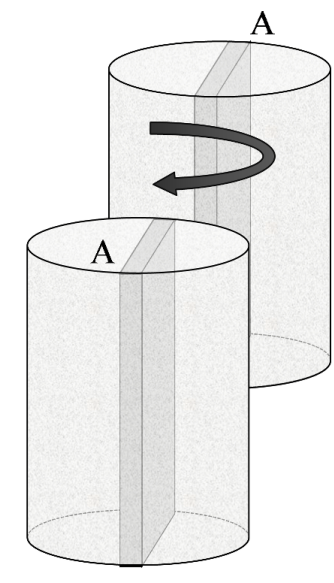

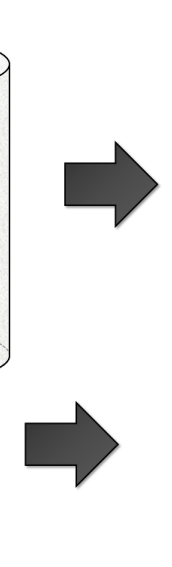

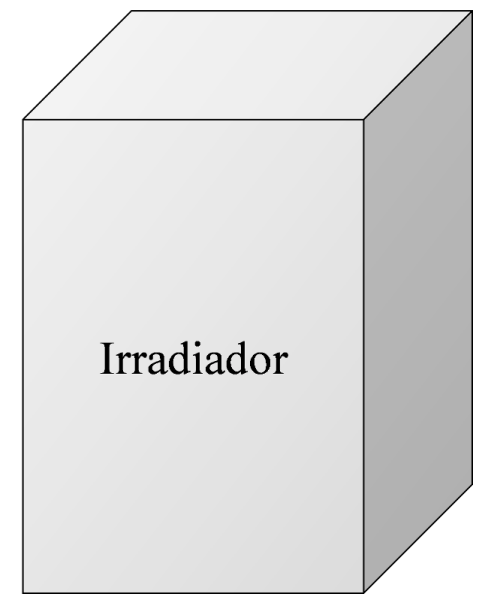

Figura 3.23. Esquema ilustrando o procedimento para obtenção do mapa de isodoses exibido na Figura 3.22(d).

O histograma de dose absorvida mostra que a sua distribuição percentual no volume irradiado possui distribuição análoga ao comportamento de uma gaussiana centrada em 100 \%, Figura 3.24. Embora as distribuição apresente valores significativos entre $\approx 80$ até $130 \%$, tal inomogeneidade mostra-se aceitável quando comparada com o intervalo de doses absorvidas recomendadas para a irradiação de sangue, já que, tomando como base uma dose central de $25 \mathrm{~Gy}$, tem-se que as doses prescritas podem aceitavelmente variar de 60 \% (15 Gy) até $200 \%$ (50 Gy) ao se considerar todas as doses aceitas pelos guias de controle de qualidade em Hemoterapia $[13,15-17,51,88,96]$. 


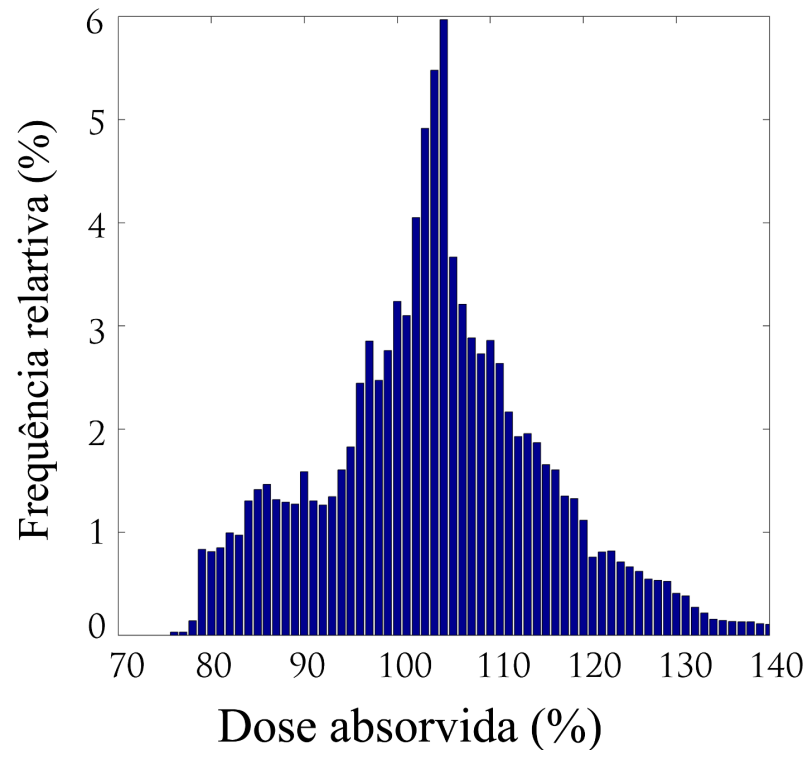

(a)

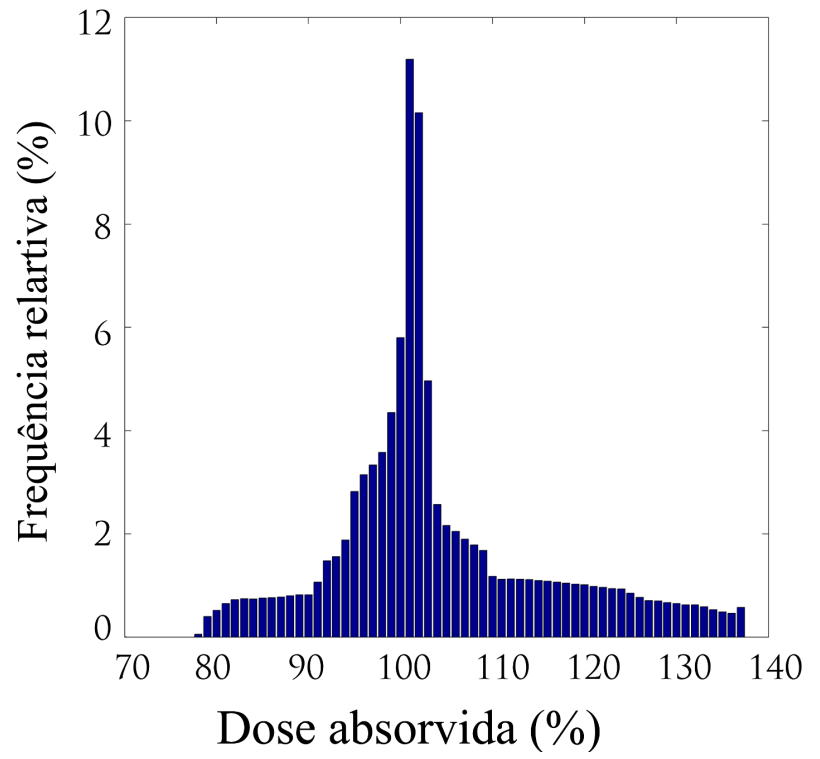

(c)

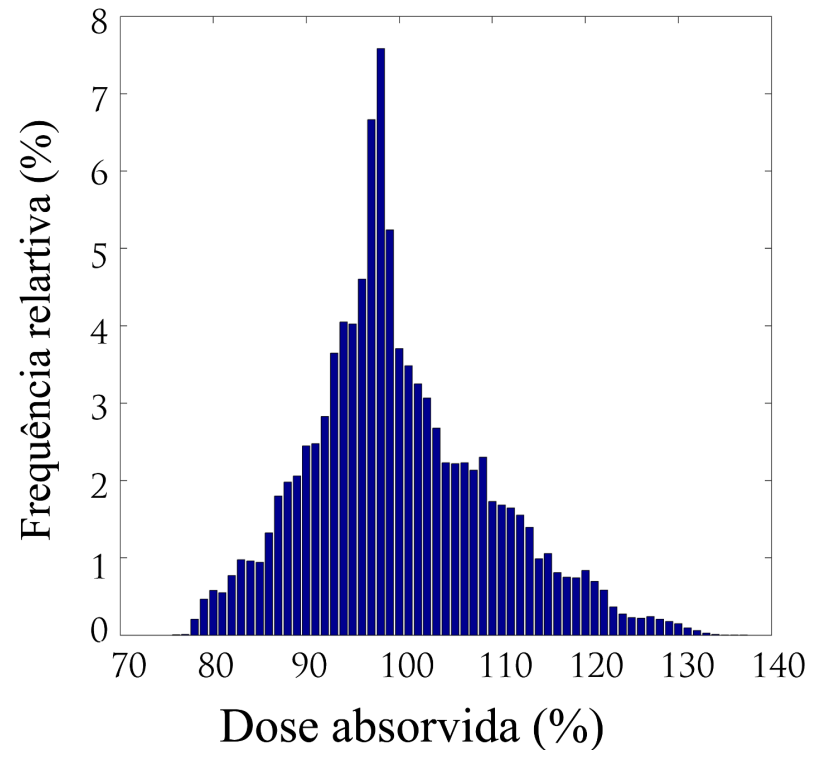

(b)

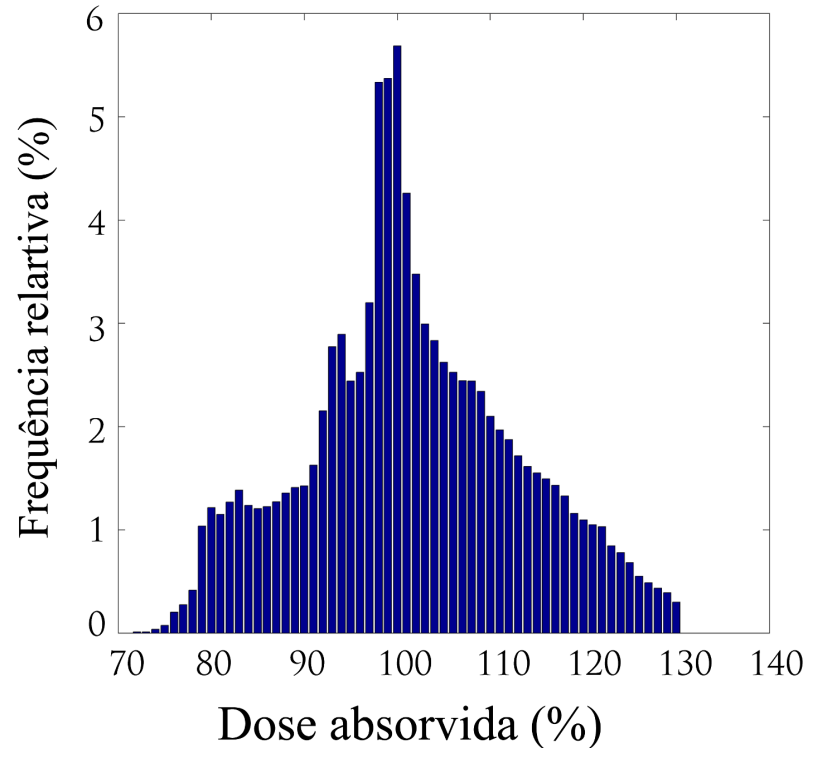

(d)

Figura 3.24. Histogramas das doses absorvidas percentuais para (a) o FXG proposto, (b) o filme, (c) os TL's e (d) os dados do fabricante. 
As regiões periféricas das distribuições de doses absorvidas, em especial a metade inferior, apresentam os maiores gradientes e nelas estão as diferenças mais substanciais quando os dados do FXG são comparados com os provenientes da dosimetria de referência (filme e TL's). As diferenças percentuais encontradas entre o dosímetro FXG proposto e 1) o filme, 2) os TL's e 3) o fabricante são exibidas na Figura 3.25. Pode ser notado que ocorreram diferenças mais significativas nas bordas dos mapas, o que pode estar relacionado à faixa de trabalho dos dosímetros. A faixa de trabalho das doses absorvidas, isto é, à faixa que apresenta melhor relação sinal/ruído, pode ter sido uma razão para as diferenças encontradas entre os mapas, uma vez que as irradiações não puderam ser simultâneas, pois o filme e os TL's apresentam efeitos de não linearidade para doses acima de $\approx 20$ e $10 \mathrm{~Gy}$, respectivamente, enquanto que o FXG proposto tem a necessidade de valores maiores do que 15 Gy para razões sinal/ruído adequadas. Isso pode ter contribuído para aumentar as diferenças entre os dosímetros já que as condições de contorno não foram exatamente as mesmas.

\subsubsection{Isodoses utilizando o código PENELOPE}

O código PENElope já foi utilizado para simular a irradiação de dosímetros do tipo gel com sucesso [253, 254]. Nesse sentido, a simulação com o referido código também foi estudada como ferramenta complementar para averiguar as distribuições das doses absorvidas, obtidas com o irradiador específico de sangue. Os resultados obtidos para as simulações PENELOPE encontram-se ilustrados na Figura 3.26. Comparando-se os mapas de doses absorvidas para o FXG proposto e o sangue, notase a similaridade entre os valores das porcentagens de dose absorvida, o que indica que as interações da radiação com a matéria ocorrem de forma análoga. Isso é de interesse prático em termos de dosimetria, pois permite que fatores de correção sejam desprezados sem perda significante de exatidão ao se determinar a dose absorvida ou outra grandeza dosimétrica.

Embora as interações tenham ocorrido de maneira equivalente, diferenças percentuais entre ambas as simulações puderam ser verificadas, as quais estão ilustradas na Figura 3.27(a). O mapa corresponde às diferenças do sangue em relação ao FXG proposto e estão graduadas de azul até o vermelho (-10\% até $10 \%$, respectivamente). Conforme pode ser visto, as diferenças entre o dosímetro proposto e 


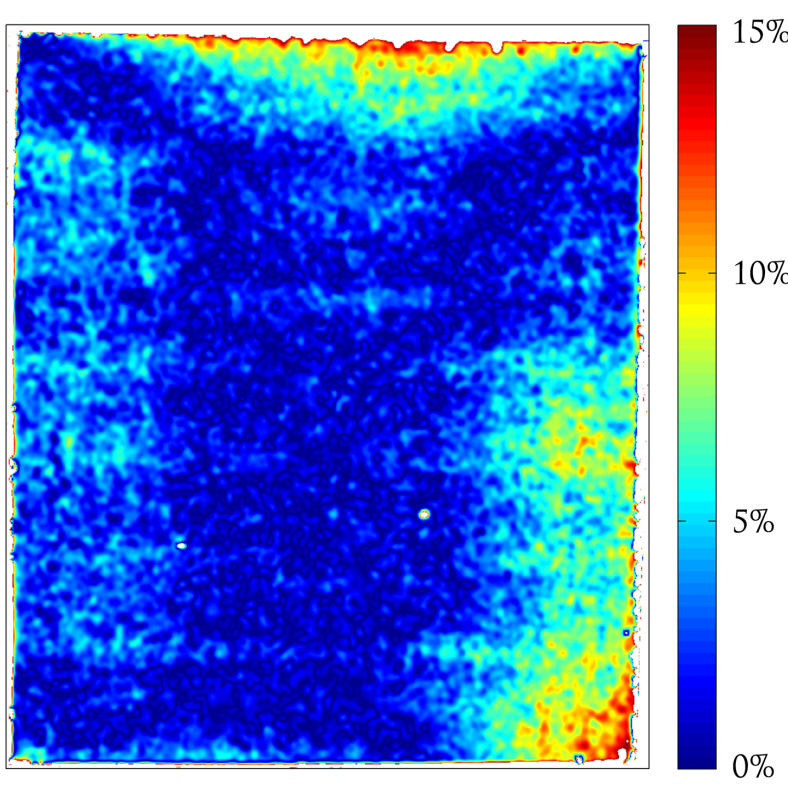

(a)

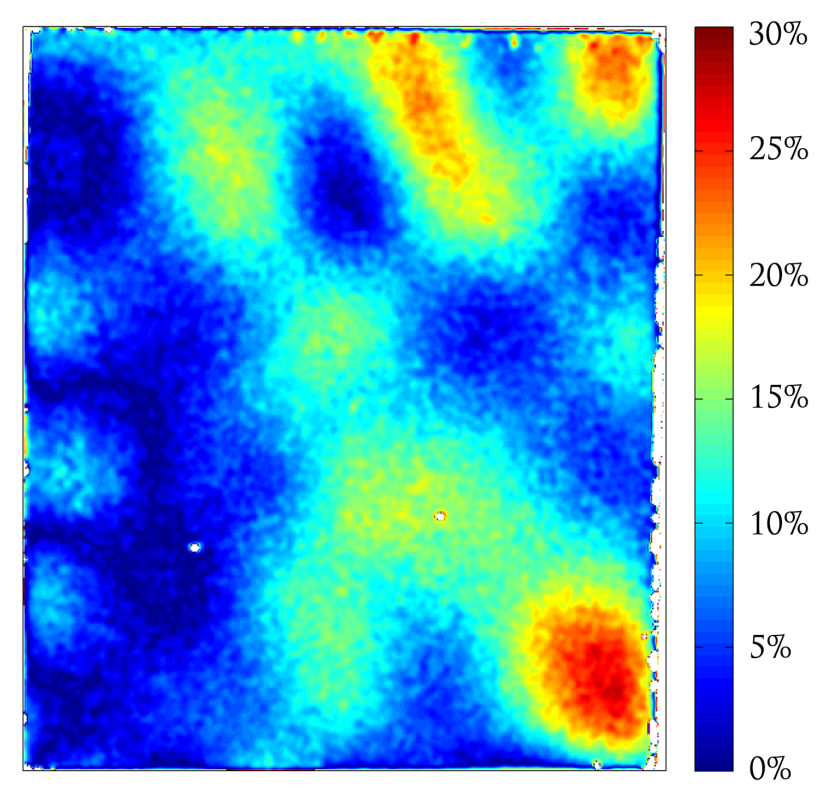

(b)

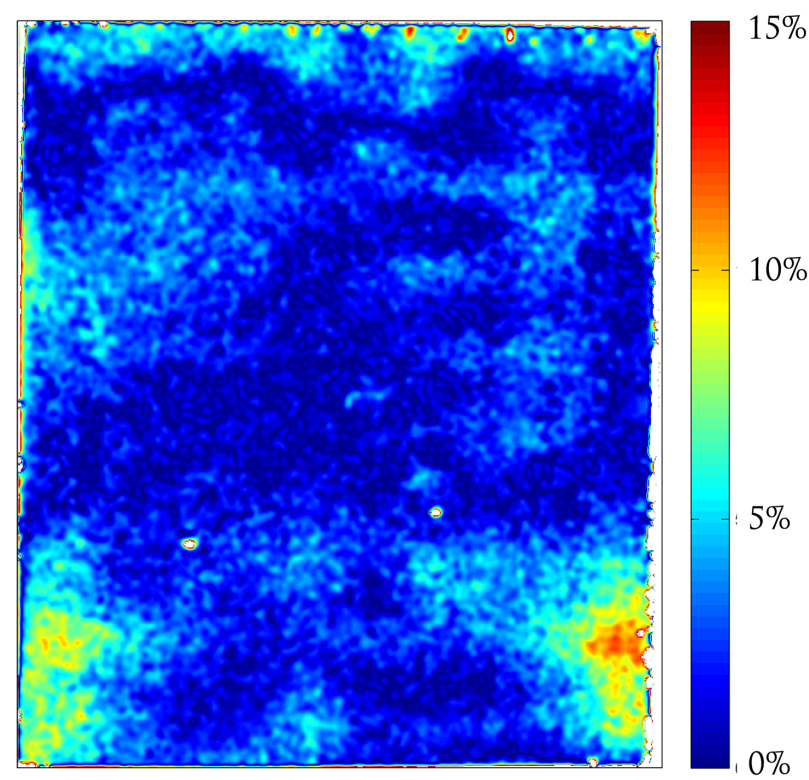

(c)

Figura 3.25. Diferenças percentuais entre os mapas de isodoses obtidos com (a) o FXG proposto, (b) o filme e (c) os TL's. 


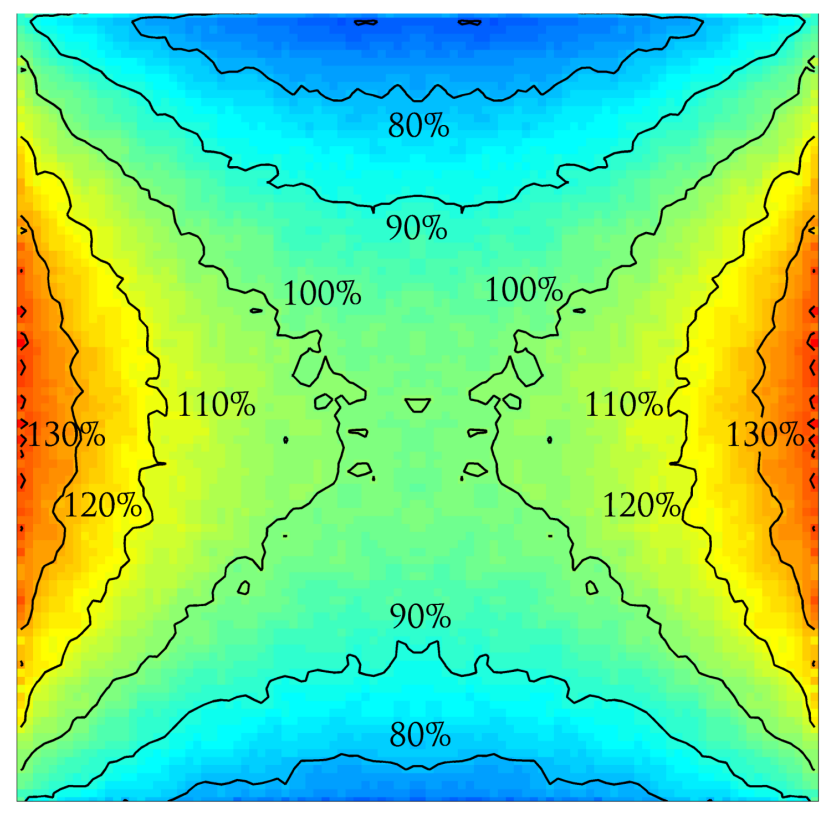

(a)

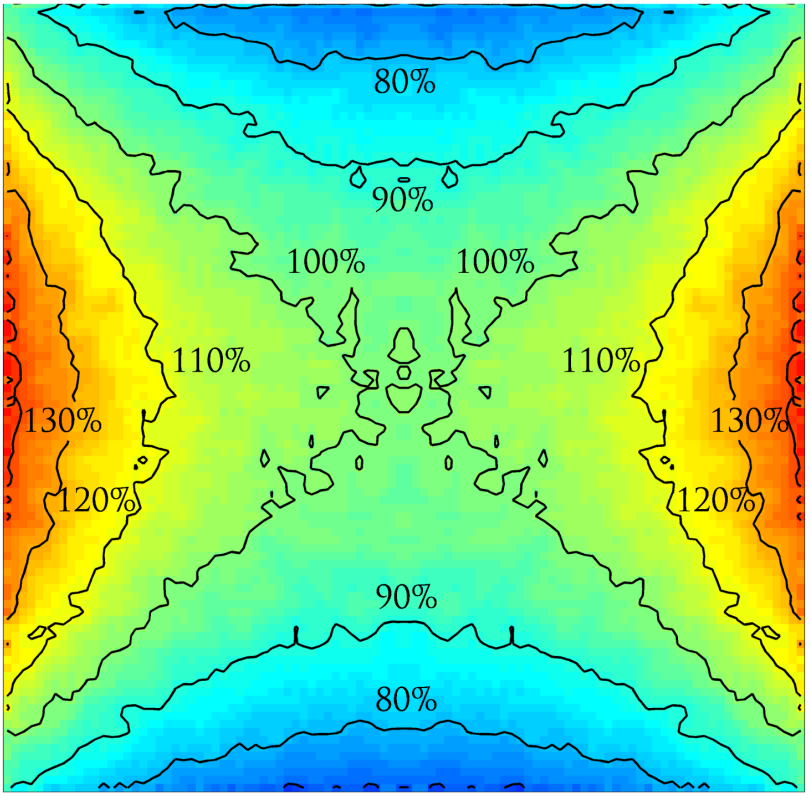

(b)

Figura 3.26. Curvas de isodoses simuladas com o código Penelope para o (a) dosímetro FXG proposto e (b) o sangue, considerando as condições do irradiador Gammacell $3000^{\circledR}$.

o sangue foram, em geral, menores do que $\pm 5 \%$, o que é mais claro pelo histograma da Figura 3.27(b). Diferenças dessa magnitude contribuem para mostrar a adequação do dosímetro FXG proposto para a dosimetria da irradiação de sangue.

Tanto nos experimentos práticos quanto teóricos, o mapeamento bidimensional das doses absorvidas foi obtido com o vasilhame totalmente preenchido com água ou material sangue equivalente, conforme é recomendado na literaura $[4,17,92]$. Todavia, durante irradiações rotineiras, uma demanda menor de hemocomponentes pode ser necessária, quando comparada com a dosimetria (preenchimento total do volume irradiado). Para situações em que o volume estiver parcialmente preenchido, a dose máxima poderá ser maior do que aquela estimada na dosimetria. De acordo com PERKins et al, o não preenchimento do vasilhame com material sangue equivalente pode aumentar em até $25 \%$ a dose no plano médio central [255]. Dessa maneira, recomenda-se que o volume de irradiação seja sempre totalmente preenchido de acordo com os padrões realizados na dosimetria, de modo a garantir que as doses absorvidas pelas bolsas de sangue restrinjam-se aos valores recomendados pelos guias de controle de qualidade em Hemoterapia [15, 17, 88,96].

A título de comparação, simulou-se a irradiação do OS de sangue e respectivo 


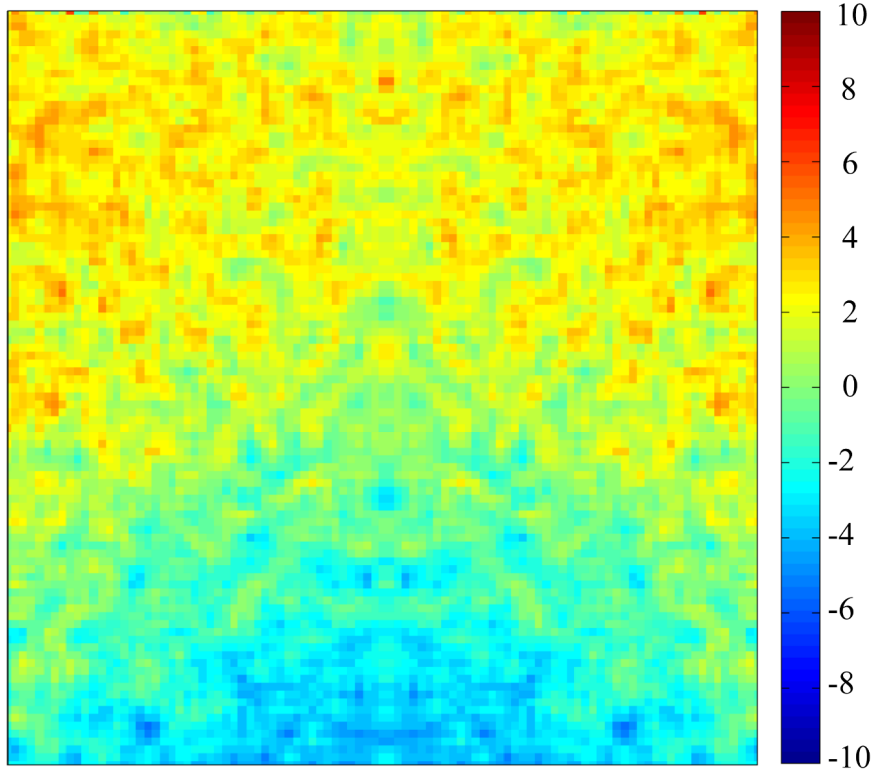

(a)

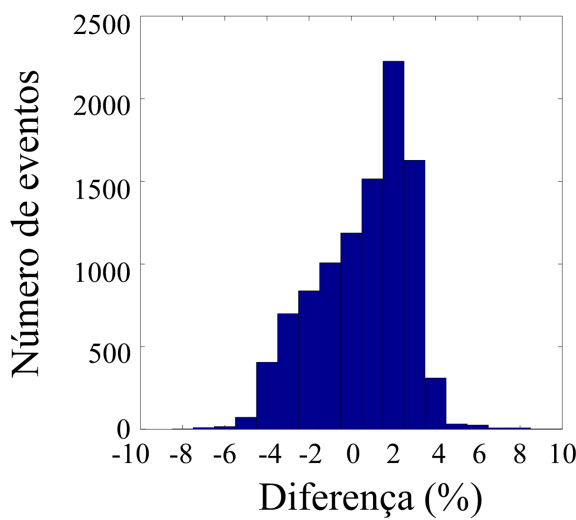

(b)

Figura 3.27. (a) Mapa e (b) histograma das diferenças percentuais entre os planos simulados para o sangue e FXG utilizando o código PENELOPE.

vasilhame por uma fonte de ${ }^{60}$ Co ao invés de uma de ${ }^{137}$ Cs. As distribuições espaciais obtidas encontram-se na Figura 3.28 e exibem uma homogeneidade ligeiramente maior para doses absorvidas entre 80 e $100 \%$, conforme mostra a Figura 3.29. Apesar da maior homogeneidade conseguida com o cobalto, essa melhoria não se mostra significativa o suficiente para se adotar um irradiador de ${ }^{60} \mathrm{Co}$, especialmente ao se considerar os fatores de radioproteção necessários para se utilizarem fontes com "altas" energia e atividade. Por outro lado, a irradiação por equipamentos teleterápicos pode ser adotada como uma alternativa viável, como reportado por LUBAN et al, a utilização de aceleradores lineares para a irradiação de sangue pode resultar em isodoses com a metade da variação daquela obtida com um irradiador de ${ }^{137} \mathrm{Cs}[256]$. 


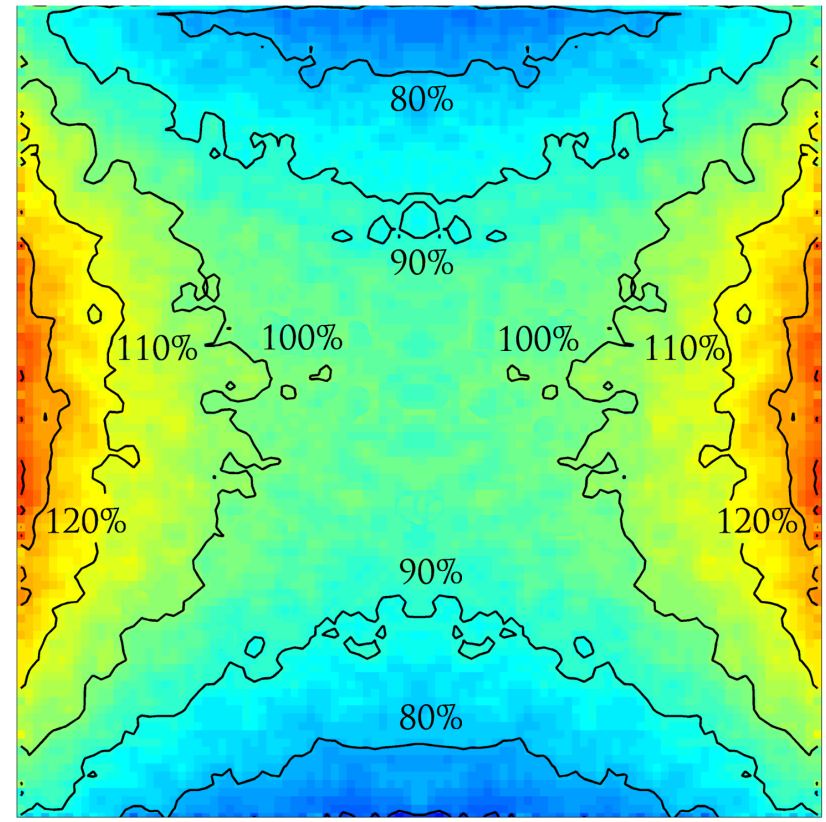

Figura 3.28. Curvas de isodoses simuladas com o código PENELOPE para o sangue, considerando as condições do irradiador Gammacell $3000{ }^{\circledR}$ com uma fonte de ${ }^{60} \mathrm{Co}$.

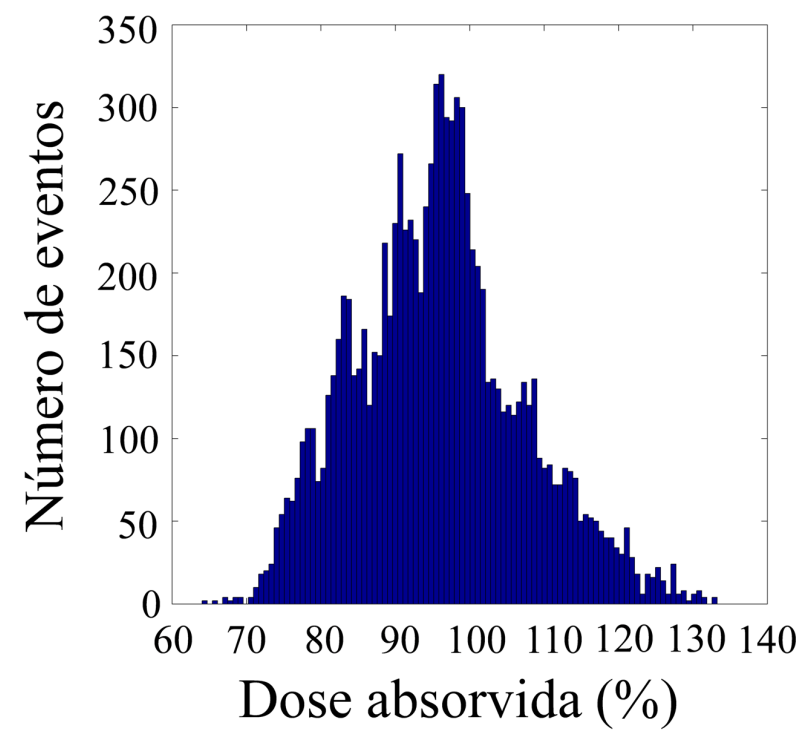

(a)

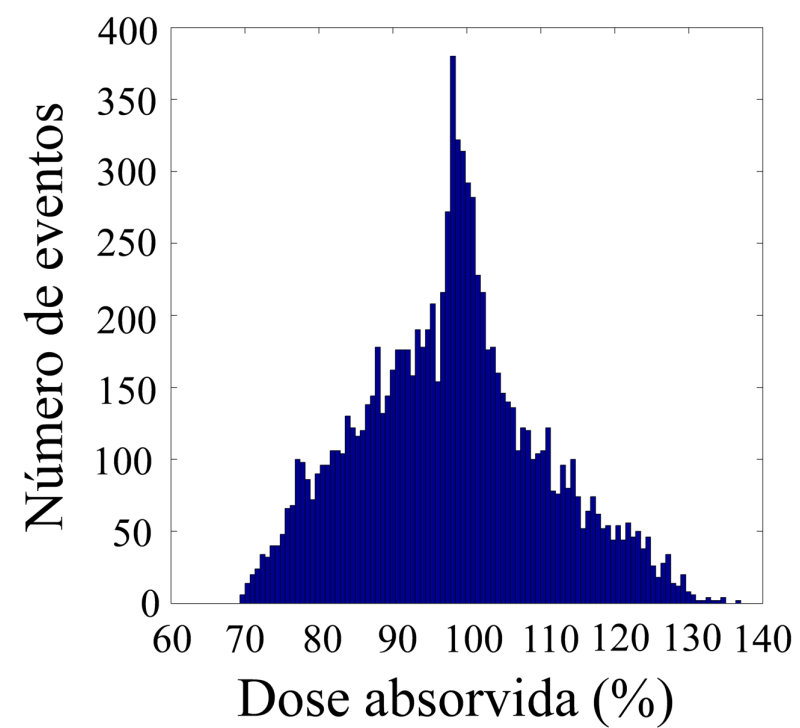

(b)

Figura 3.29. Histogramas das doses absorvidas simuladas com o irradiador de sangue considerando uma fonte de (a) ${ }^{60} \mathrm{Co}$ e (b) ${ }^{137} \mathrm{Cs}$. 


\section{CONCLUSÕES}

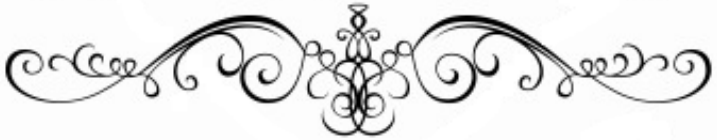




\section{Capítulo}

\section{CONCLUSÕES}

A partir dos resultados obtidos neste trabalho, algumas conclusões puderam ser feitas quanto ao comportamento dos dosímetros FXG original, testados e proposto.

O aumento da concentração do sulfato ferroso amoniacal na solução original não promoveu aumentos na faixa de linearidade da resposta em dose absorvida, tampouco na sensibilidade, contudo ocasionou um desvanecimento mais rápido da resposta do FXG. Já a diminuição em sua concentração reduziu tanto a faixa de linearidade, quanto a sensibilidade do dosímetro.

O aumento da concentração da gelatina de pele de porco proporcionou uma saturação mais prematura na resposta em dose absorvida do dosímetro e uma diminuição em sua sensibilidade, acompanhada de aumentos no desvanecimento do sinal. A completa remoção da gelatina da solução permitiu inferência da doses absorvidas em todo o intervalo desejado, porém prejudicou a sua determinação espacial pelo fato do dosímetro ter se tornado uma solução aquosa.

Aumentos na concentração do ácido sulfúrico permitiram ampliação da faixa de linearidade em resposta de dose absorvida para o FXG, porém com significativas reduções na sensibilidade do dosímetro. Em termos de desvanecimento do sinal, o aumento do ácido na solução tendeu a deixar o dosímetro mais instável temporalmente.

Ao ter sua concentração aumentada, o Alaranjado de Xilenol (XO) permitiu inferências em todo o intervalo de doses absorvidas necessário para a prevenção da DECH-AT, com pequenas reduções na sensibilidade e no desvanecimento do sinal, quando comparadas às do FXG original. A concentração de $X O$ mostrou-se diretamente proporcional à saturação da resposta em dose absorvida, de modo que 
ao ter sua concentração reduzida à metade, o valor da saturação também foi reduzido em proporção praticamente igual.

A adição do cloreto de sódio à solução promoveu maior precisão nas respostas em dose absorvida dos dosímetros FXG, sem alterações perceptíveis nas características de linearidade, sensibilidade e desvanecimento do sinal, de modo que esse composto foi incorporado ao dosímetro proposto.

A receita proposta neste trabalho para o uso do dosímetro FXG no controle de qualidade da irradiação de sangue mostrou-se adequada em termos de linearidade, sensibilidade e dependências quanto à temperatura, à taxa de dose e à energia. Além disso, sua resolução em termos de dose absorvida e sua estabilidade de armazenamento também mostraram características apropriadas para uso rotineiro na dosimetria em um banco de sangue.

Tanto o dosímetro FXG original quanto o proposto mostraram equivalência em termos de interação da radiação ionizante com o sangue, em campos de fótons e elétrons. Em campos de fótons, ambos apresentaram equivalências equiparáveis, porém em campos de elétrons, o FXG proposto foi significativamente mais sangue equivalente do que o FXG original. Assim, ambos os dosímetros podem ser empregados sem a aplicação de fatores de correção para a inferência das doses absorvidas, além de poderem ser também empregados como objeto simuladores do sangue.

O FXG proposto foi capaz de inferir espacialmente a dose absorvida no plano central do volume irradiado de um irradiador específico de sangue. Os resultados obtidos com essa dosimetria foram corroborados por medidas realizadas com TL's, filmes e simulação Monte Carlo e mostraram o gradiente de doses que pode ocorrer com esse tipo de irradiador.

As medidas realizadas com o espectrofotômetro e o sistema $C C D$ desenvolvido mostraram-se adequadas tanto para o dosímetro FXG original quanto para o proposto. Com o referido sistema, notou-se maior praticidade e facilidade em se determinarem as distribuições espaciais da dose absorvida para dado plano irradiado.

Pelo que foi mostrado neste trabalho, o FXG proposto e as sistemáticas de aquisição e análise, em especial a $C C D$, podem ser utilizados pela equipe de um banco de sangue para o controle de qualidade em irradiações de sangue, mostrando-se como uma alternativa viável e factível diante de opções como dosímetros TL's e filmes. As 
características do FXG proposto apresentaram qualidades equiparáveis aos referidos dosímetros comerciais, com a vantagem de poder ser preparado no póprio banco de sangue e ter um controle de qualidade a ele associado, o que contribui em termos de rastreabilidade metrológica.

Por fim, sugerem-se como trabalhos futuros para a dosimetria FXG na irradiação de sangue: 1) a análise da difusão dos íons férricos pelo dosímetro proposto, de modo a quantificar a precisão espacial das medidas ao longo do tempo, 2) a caracterização e o desenvolvimento de porta-amostras microvolumétricos para a dosimetria de bolsas de sangue e 3) a determinação do $G\left(F e^{+3}\right)$ para o FXG proposto em diferentes energias empregadas na irradiação de sangue. 


\section{REFERÊNCIAS BIBLIOGRÁFICAS}

1 Bero, M. A.; GILBOY, W. B.; GLOVER, P. M.; EL-MASRI, H. M.

Tissue-equivalent gel for non-invasive spatial radiation dose measurements. Nuclear Instruments and Methods in Physics Research B, v. 166-167, p. 820-825, 2000. iv, $4,20,22,25,65,147$

2 GRAW, R. G.; WHANG-PENG, J.; KRÜGER, G.; BUCKNER, C. D.; LEVEnthal, B. G.; BERARD, C.; HENDERSON, E. S. Complication of bone-marrow transplantation graft-versus-host disease resulting from chronicmyelogenous-leukæmia leucocyte transfusions. The Lancet, v. 296, n. 7668, p. 338-341, 1970. 2, 14

3 PELSZYNSKI, M. M.; MOROFF, G.; NAOMI, L. C. Effect of $\gamma$ irradiation of red blood cell units on T-cell inactivation as assessed by limiting diluiton analysis: Implications for preventing transfusion-associated graft-versus-host disease. Blood, v. 83, p. $1583-1589,1994.2,8,10,11,13$

4 MASTERSON, M. E.; FEBO, R. Pretransfusion blood irradiation: Clinical rationale and dosimetric considerations. Medical Physics, v. 19, n. 3, p. 649-657, 1992. $2,10,11,17,27,55,56,93,95,98,100,106$

5 MOROFF, G.; LUBAN, N. L. C. The irradiation of blood and blood components to prevent graft-versus-host disease: Technical and guidelines. Transfusion Medicine, v. 11, p. 15-26, 1997. 2, 10, 11, 12, 16, 17, 55, 91, 93, 95, 146

6 MOrofF, G.; Leitman, S. F.; LUBAN, N. L. C. Principles of blood irradiation, dose validation, and quality control. Transfusion, v. 37, p. 1084-1092, 1997. $2,3,10,55,56,93,95,146$

7 AnDERSON, K. C.; GOODNOUGH, L. T.; SAYERS, M. Variation in blood component irradiation pratice: Implication for prevention of transfusion-associated graft-versus-host disease. Blood, v. 77, p. 2096-2102, 1991. 2, 9, 16 
8 BUtSON, M. J.; YU, P. K. N.; CHEUnG, T.; CAROLAN, M. G.; QUACH, K. Y.; ARNOLD, A.; METCALFE, P. E. Dosimetry of blood irradiaton with radiochromic film. Transfusion Medicine, v. 9, p. 205-208, 1999. 2, 17, 28, 95

9 PATTON, G. A.; SKOWRONSKI, M. G. Implementation of a blood irradiation program at a community cancer center. Transfusion, v. 41, p. 1610-1614, 2001. 2, 4,16

10 CHEN, F.; COVAS, D. T.; BAFFA, O. Dosimetry of blood irradiation using an alanine/ESR dosimeter. Applied Radiation and Isotopes, v. 55, p. 13-16, 2001. 2,17

11 IAEA. TECDOC-934. Effects of ionizing radiation on blood and blood components: A survey. Viena, Áustria, 1997. 3

12 FDA. Recommendations Regarding License Amendments and Procedures for Gamma Irradiation of Blood Products. Bethesda, MD, EUA, 1993. 3, 10, 11, 13, 145

13 AABB. Standards for Blood Banks and Transfusion Services. 27th ed. 25. ed. Bethesda, MD, EUA, 2011. 3, 12, 13, 14, 29, 102, 145

14 MINISTÉRIO DA SAÚDE. Regulamento Técnico. Brasil, 2004. 68-121 p. 3,13

15 COUNCIL OF EUROPE. Guide to the Preparation, Use and Quality Assurance of Blood Components. Recommendation No. R (95) 15. 13. ed. Strasbourg, France, 2011. 3, 13, 14, 102, 106

16 TRElEAVEn, J.; GENNERY, A.; MARSH, J.; NORFOLK, D.; PAGE, L.; PARKER, A.; SARAN, F.; THURSTON, J.; WEBB, D. Guidelines on the use of irradiated blood components prepared by the British Committee for Standards in Haematology blood transfusion task force. British Journal of Haematology, v. 152, n. 1 , p. $35-51,2010.3,10,14,102$ 
17 BCSH Blood Transfusion Task Force. Guidelines for irradiation of blood and blood components for the prevention of transfusion-associated graft-versus-host disease. Transfusion Medicine, v. 6, p. 261-271, 1996. 3, 10, 14, 98, 102, 106, 146

18 SPROUl, A. M.; CHAlmerS, E. A.; Mills, K. I.; BURneTT, A. K.; SIMPSON, E. Third party mediated graft rejection despite irradiation of blood products. British Journal of Haematology, v. 80, p. 251-252, 1992. 3

19 LOWENTHAL, R. M.; CHALLIS, D. R.; GRIFFITHS, A. E.; CHAPPELL, R. A.; GOULDER, P. J. Transfusion-Associated Graft-versus-Host Disease: Report of an occurrence following the administration of irradiated blood. Transfusion, v. 33 , p. $524-529,1993.3,13$

20 Drobynski, W.; THIBODEAU, S.; TRUITT, R. L.; BAXTER-LOWE, L. A.; GORSKI, J.; JENKINS, R.; GOTTSCHALL, J.; ASH, R. C. Third-partymediated graft rejection and graft-versus-host disease after T-cell-depleted bone marrow transplantation, as demonstrated by hypervariable DNA probes and HLA-DR polymorphism. Blood, v. 74, p. 2285-2294, 1989. 3, 7

21 MOREiRA, M. V.; AlmeidA, A. de; COSTA, R. T.; PERleS, L. A. FXG mass attenuation coefficient evaluation for radiotherapy routine. Journal of Physics: Conference Series, v. 3, p. 146-149, 2004. 4, 25

22 AlVA, M.; SAMPAIO, F. G. A.; MOREIRA, M. V.; PETCHEVIST, P.; ALMEIDA, A. D. Absorbed dose distribution visualization for superficial treatments through the Fricke Xylenol Gel dosimeter (FXG). Journal of Physics: Conference Series, v. 250, n. 1, 2010. 4, 25

23 SAMPAiO, F. G. A.; PETCHEVIST, P. C. D.; DEL LAMA, L. S.; ALMEIDA, A. de. Matched fields technique for ${ }^{90} \mathrm{Sr} /{ }^{90} \mathrm{Y}$ low-dose rate source for keloid treatments. IEEE Transactions on Nuclear Science, v. 60, n. 2, p. 837-842, 2013. 4

24 HATHAWAY, W. E.; GITHENS, J. R.; BLACKBURN, W. R.; FULGINITI, V.; KEMPE, C. H. Aplastic anaemia, histiocytosis and erythroderma in immunologically deficient children. New England. Journal of Medicine, v. 273, p. 953-958, 1965. 6, 7 
25 VON FLIENDNER, V.; HIGBY, D. J.; KIM, U. Graft-versus-host reaction following blood transfusion. American Journal of Medicine, v. 72, n. 6, p. 951-959, 1982. $6,7,9$

26 BURnS, L. J.; WeStBerG, M. W.; BURnS, C. P.; KLASSEN, L. W.; GOEKEN, N. E.; RAY, T. L.; MACFARLANE, D. E. Acute graft-versus-host disease resulting from normal donor blood transfusions. Acta Hematologica, v. 71, n. 4, p. $270-276,1984.6,9$

27 ANDERSON, K. C.; WEINSTEIN, H. J. Transfusion-associated graft-versushost disease. New England Journal of Medicine, v. 323, p. 315-321, 1990. 6, 9

28 GREENBAUM, B. H. Transfusion-associated garft-versus-host disease: Historical perspectives, incidence, and current use of irradiated blood products. Journal of Clinical Oncology, v. 9, n. 10, p. 1889-1902, 1991. 6, 9

29 PETZ, L. D.; CALHOUN, P.; YAM, M. Transfusion-associated graft-versushost disease in immunocompetent patients: Report of a fatal case associated with transfusion of blood from a second-degree relative and a survey of predisposing factors. Transfusion, v. 33, p. 742-750, 1993. 6, 8, 13

30 OHTO, H.; ANDERSON, K. C. Survey of transfusion-associated graft-versushost disease in immunocompetent recipients. Transfusion Medicine Reviews, v. 10, n. 1, p. $31-43,1996.6,8$

31 LUBAn, N. L. C.; DROThleR, D.; MOROFF, G.; QUinONES, R. Irradiation of platelet components: Inhibition of lymphocyte proliferation assessed by limiting-dilution analysis. Transfusion, v. 40, n. 3, p. 348-352, 2000. 6, 11

32 AOUn, E.; SHAMSEDDINE, A.; CHEHAL, A.; OBEID, M.; TAHER, A. Transfusion-associated GVHD: 10 years' experience at the American University of Beirut-Medical Center. Transfusion, v. 43, n. 12, p. 1672-1676, 2003. 6, 7, 8

33 TRIULZI, D.; DUQUESNOY, R.; NICHOLS, L.; CLARK, K.; JUKIC, D.; ZEEVI, A.; MEISNER, D. Fatal transfusion-associated graft-versus-host disease in 
an immunocompetent recipient of a volunteer unit of red cells. Transfusion, v. 46, p. $885-888,2006.6,7$

34 AgBAht, K.; Altintas, N. D.; TOPELI, A.; GOKOZ, O.; OZCEBE, O. Transfusion-associated graft-versus-host disease in immunocompetent patients: case series and review of the literature. Transfusion, v. 47, n. 8, p. 1405-1411, 2007. 6,8

35 OHTO, H.; YASUDA, H.; NOGUCHI, M.; ABE, R. Risk of transfusionassociated graft-versus-host disease as a result of directed donations from relatives. Transfusion, v. 32, n. 7, p. 691-693, 1992. 6, 8

36 HUtChinsOn, K.; KOPKO, P. M.; MUtO, K. N.; TUSCANO, J.; O’DOnNell, R. T.; HOLLAND, P. V.; RICHMAN, C.; PAGLIERONI, T. G.; WUN, T. Early diagnosis and successful treatment of a patient with transfusion-associated GVHD with autologous peripheral blood progenitor cell transplantation. Transfusion, v. 42, n. 12, p. 1567-1572, 2002. 6, 7

37 ANDERSON, K. Broadening the spectrum of patient groups at risk for transfusion-associated GVHD: implications for universal irradiation of cellular blood components. Transfusion, v. 43, n. 12, p. 1652-1654, 2003. 6, 8, 9

38 VAN DER MAST, B. J.; VAN DE DORPEL, M. A.; DRABBELS, J. J. M.; CLAAS, F. H. J.; WEIMAR, W. Transfusion-associated graft vs. host disease after donor-specific leukocyte transfusion before kidney transplantation. Clinical Transplantation, v. 17 , n. 5, p. 477-483, 2003. 6, 8

39 WilliamSON, L. M.; STAINSBY, D.; JONES, H.; LOVE, E.; CHAPMAN, C. E.; NAVARRETE, C.; LUCAS, G.; BEATTY, C.; CASBARD, A.; COHEN, H. The impact of universal leukodepletion of the blood supply on hemovigilance reports of posttransfusion purpura and transfusion-associated graft-versus-host disease. Transfusion, v. 47, n. 8, p. 1455-1467, 2007. 7, 8

40 YASUKAWA, M.; SHINOZAKI, F.; HATO, T.; TAKADA, K.; ISHII, Y.; TAMAI, T.; TAKAMATSU, H.; SHIOBARA, S.; YOSHIZAKI, K.; FUJITA, S. 
Successful treatment of transfusion-associated graft-versus-host disease. British Journal of Haematology, v. 86, n. 4, p. 831-836, 1994. 7

41 MORI, S.; MATSUSHITA, H.; OZAKI, K.; ISHIDA, A.; TOKUHIRA, M.; NAKAJIMA, H.; KIZAKI, M.; SUGIURA, H.; KIKUCHI, A.; HANDA, M.; KAWAI, Y.; YAMAMORI, S.; IKEDA, Y. Spontaneous resolution of transfusionassociated graft-versus-host disease. Transfusion, v. 35, n. 5, p. 431-435, 1995. 7

42 GUPTA, A.; BANSAL, D.; DASS, R.; DAS, A. Transfusion associated graft versus host disease. Indian Pediatrics, v. 41, p. 1260-1264, 2004. 7

43 NOLLET, K. E.; HOLLAND, P. V. Toward a coalition against transfusionassociated GVHD. Transfusion, v. 43, n. 12, p. 1655-1657, 2003. 7

44 AKAHOSHI, M.; TAKANASHI, M.; MASUDA, M.; YAMASHITA, A.; HASEGAWA, K.; SHIMIZU, T. K. M.; MOTOJI, T.; OSHIMI, K.; MIZOGUCHI, H. A case of transfusion-associated graft-versus-host disease not prevented by white cell-reduction filters. Transfusion, v. 32, n. 2, p. 169-172, 1992. 7

45 HAYASHI, M.; NISHIUCHI, T.; TAMURA, H.; TAKEDA, K. Transfusionassociated graft-versus-host disease caused by leukocyte-filtered stored blood. Anesthesiology, v. 79, p. 1419-1421, 1993. 7, 9, 10

46 NISHIMURA, M.; UCHIDAS, S.; MITSUNAGA, S.; YAHAGI, Y.; NAKAJIMA, K.; TADOKORO, K.; JUJI, T. Characterization of T-cell clones derived from peripheral blood lymphocytes of a patient with transfusion-associated graft-versus-host disease: Fas-mediated killing by CD4+ and CD8+ cytotoxic T-cell clones and tumor necrosis factor production by CD4+ T-cell clones. Blood, v. 89, n. 4 , p. $1440-1445,1997.7$

47 WEINMANN, M.; HOFFMANN, W.; RODEGERDTS, E.; BAMBERG, M. Biological effects of ionizing radiation on human blood compounds ex vivo. Journal of Cancer Research and Clinical Oncology, v. 126, p. 584-588, 2000. 7 
48 KLEIN, H. G. Transfusion-associated graft-versus-host disease: less fresh blood and more gray (Gy) for an aging population. Transfusion, v. 46, n. 6, p. 878-880, 2006. 8

49 TAKAHASHI, K.; JUJI, T.; MIYAMOTO, M.; UCHIDA, S.; AKAZA, T.; TADOKORO, K.; SHIBATA, Y.; INO, T.; HIDANO, A. Analysis of risk factors for post-transfusion graft-versus-host disease in Japan. The Lancet, v. 343, n. 8899, p. 700-702, 1994. 8

50 DWYRE, D. M.; HOLLAND, P. V. Transfusion-associated graft-versus-host disease. Vox Sanguinis, v. 95, n. 2, p. 85-93, 2008. 8

51 ASAI, T.; INABA, S.; OHTO, H.; OSADA, K.; SUZUKI, G.; TAKAHASHI, K.; TADOKORO, K.; MINAMI, M. Guidelines for irradiation of blood and blood components to prevent post-transfusion graft-vs.-host disease in Japan. Transfusion Medicine, v. 10, n. 4, p. 315-320, 2000. 8, 14, 102

52 MESCHINI, P. B. R.; PALITTI, F. Effects of storage conditions of human whole blood on the viability of lymphocytes. International Journal of Radiation Biology, v. 84, n. 7, p. 613-619, 2008. 8

53 OTSUBO, H.; YAMAGUCHI, K. Current risks in blood transfusion in Japan. Japanese Journal of Infectious Diseases, v. 61, n. 6, p. 427-433, 2008. 8

54 JUJI, T.; TAKAHASHI, K.; SHIBATA, Y.; IDE, H.; SAKAKIBARA, T.; INO, T.; MORI, S. Post-transfusion graft-versus-host disease in immunocompetent patients after cardiac surgery in Japan. The New England Journal of Medicine, v. 321, n. 1 , p. $56,1989.8,9$

55 SAITO, M.; TAKAMATSU, H.; NAKAO, S.; SHIOBARA, S.; TMATSUDA; TAJIKA, E.; NAKAMURA, T.; KAJI, T.; YOSHIDA, T. Transfusion-associated graft-versus-host disease after surgery for bladder cancer. Blood, v. 82, n. 1, p. 326-327, 1993. 9

56 SPITZER, T. R.; CAHILL, R.; COTTLER, F. M.; TREAT, J.; SACHER, R.; DEEG, H. J. Transfusion-induced graft-versus-host disease in patients with 
malignant lymphoma. A case report and review of the literature. Cancer, v. 66, n. 11, p. 2346-2349, 1990. 9

57 GELLY, K. J.; KERR, R.; RAWLINSON, S.; NORRIS, A.; BOWEN, D. T. Transfusion-associated graft vs.host disease in a patient with high-grade B-cell lymphoma. Should cellular products for patients with non-Hodgkin's lymphoma be irradiated? British Journal of Haematology, v. 110, n. 1, p. 228-229, 2000. 9

58 POPOVSKY, M. A.; BEnSON, K.; GLASSMAN, A. B.; HUME, H.; OBERMAN, H. A.; PISCIOTTO, P. T.; ANDERSON, K. C. Transfusion practices in human immunodeficiency virus-infected patients. Transfusion, v. 35, n. 7, p. 612-616, 1995. 9

59 KLEIN, C.; FRAITAG, S.; FOUlON, E.; RAFFOUX, C.; BODEMER, C.; BLANCHE, S. Moderate and transient transfusion-associated cutaneous graft-versus-host disease in a child infected by human immunodeficiency virus. American Journal of Medicine, v. 101, n. 4, p. 445-446, 1996. 9

60 APPletON, A. L.; SVILAND, L.; PEARSON, A. D.; WILKES, J.; GREEN, M. A.; MALCOLM, A. J. Diagnostic features of transfusion associated graft versus host disease. Journal of Clinical Pathology, v. 47, n. 6, p. 541-546, 1994. 9

61 FAST, L. D. Development in the prevention of transfusion-associated-graftversus-host disease. British Journal of Haematology, v. 158, n. 5, p. 563-568, 2012. 9,14

62 CROWLEY, J. P.; SKRABUT, E. M.; VALERI, C. R. Immunocompetent lymphocytes in previously frozen washed red cells. Vox Sanguinis, v. 26, p. 513-517, 1974. 9

63 SPRENT, J.; ANDERSON, R. E.; MILLER, J. F. Radiosensitivity of T and B lynphocytes. II effect of irradiation on response of $\mathrm{T}$ cells to alloantigens. European Journal of Immunology, v. 4, p. 204-210, 1974. 10, 13

64 CHOU, C. H.; CHEN, P. J.; LEE, P. H.; CHENG, A. L.; HSU, H. C.; CHENG, J. Radiation-induced hepatitis $\mathrm{B}$ virus reactivation in liver mediated by the 
bystander effect from irradiated endothelial cells. Clinical Cancer Research, v. 13, n. 3 , p. $851-857,2007.10$

65 MOROFF, G.; HOLme, S.; AUBuChOn, J. P.; HEATON, W. A.; SWEENEY, J. D.; FRIEDMAN, L. I. Viability and in vitro properties of AS-1 red cells after gamma irradiation. Transfusion, v. 39, n. 2, p. 128-134, 1999. 10, 11, 12

66 HIRAYAMA, J.; ABE, H.; AZUMA, H.; IKEDA, H. Leakage of potassium from red blood cells following gamma ray irradiation in the presence of dipyridamole, trolox, human plasma or mannitol. Biological \& Pharmaceutical Bulletin, v. 28, n. 7 , p. $1318-1320,2005.10$

67 BASHIR, S.; NAIK, F.; CARDIGAN, R.; THOMAS, S. Effect of X-irradiation on the quality of red cell concentrates. Vox Sanguinis, v. 101, n. 3, p. 200-207, 2011. 10

68 GÓES, E. G.; OtTOBOni, M. A.; PAlma, P. V. B.; MORAis, F. R.; PELÁ, C. A.; BORGES, J. C.; COVAS, D. T. Quality control of blood irradiation with a teletherapy unit: Damage to stored red blood cells after cobalt-60 gamma irradiation. Transfusion, v. 48, p. 332-340, 2008. 11

69 DAVEY, R. J.; MCCOY, N. C.; YU, M.; SUlliVAN, J. A.; SPIEGEL, D. M.; LEITMAN, S. F. The effect of pre-storage irradiation on post-transfusion red cell survival. Transfusion, v. 32, n. 6, p. 525-528, 1992. 11, 12

70 RELEVY, H.; KOSHKARYEV, A.; MANNY, N.; YEDGAR, S.; BARSHTEIN, G. Blood banking-induced alteration of red blood cell flow properties. Transfusion, v. 48, n. 1, p. 136-146, 2008. 11

71 BARSHTEIN, G.; MANNY, N.; YEDGAR, S. Circulatory risk in the transfusion of red blood cells with impaired flow properties induced by storage. Transfusion Medicine Reviews, v. 25, n. 1, p. 24-35, 2011. 11

72 WAGNER, S. J.; MYRUP, A. C. Prestorage leucoreduction improves several in vitro red cell storage parameters following gamma irradiation. Transfusion Medicine, v. 16, p. 261-265, 2006. 11, 12 
73 WEISKOPF, R. B.; SCHNAPP, S.; ROUINE-RAPP, K.; BOSTROM, A.; TOY, P. Extracellular potassium concentrations in red blood cell suspensions after irradiation and washing. Transfusion, v. 45, n. 8, p. 1295-1301, 2005. 11, 12

74 SAMUEL, L. H.; ANDERSON, G.; MINTZ, P. D. Rejuvenation of irradiated AS-1 red cells. Transfusion, v. 37, n. 1, p. 25-28, 1997. 11

75 HEATON, A. Blood component irradiation and prevention of Graft-versus-Host Disease. Transfusion Science, v. 16, n. 2, p. 121-123, 1995. 11

76 ButTon, L. N.; DEWOlF, W. C.; NEWBURGER, P. E.; JACOBSON, M. S.; KEVY, S. V. The effects of irradiation on blood components. Transfusion, v. 21, n. 4, p. $419-426,1981.11,13$

77 BESSOS, H.; ATKINSON, A.; MURPHY, W. G.; MCGILL, A.; ROBERTSON, M.; SEGHATCHIAN, M. J.; VICKERS, M.; BISHOP, D.; TANDY, $\mathrm{N}$. A comparison of in vitro storage markers between gamma-irradiated and non-irradiated apheresis platelet concentrates. Transfusion Science, v. 16, n. 2, p. 131-134, 1995. 12

78 REVERBERI, R.; GOVONI, M.; VERENINI, M. Deformability and viability of irradiated red cells. Annali dell'Istituto Superiore di Sanità, v. 43, n. 2, p. 176-185, 2007. 12

79 STRAUSS, R. G. Data-driven blood banking practices for neonatal RBC transfusions. Transfusion, v. 40, n. 12, p. 1528-1540, 2000. 12

80 HALL, T. L.; BARNES, A.; MILlER, J. R.; BETHEnCOURT, D. M.; NESTOR, L. Neonatal mortality following transfusion of red cells with high plasma potassium levels. Transfusion, v. 33, n. 7, p. 606-609, 1993. 12

81 RIVET, C.; BAXTER, A.; ROCK, G. Potassium levels in irradiated blood. Transfusion, v. 29, n. 2, p. $185,1989.12$

82 BANSAL, I.; CALHOUN, B. W.; JOSEPH, C.; POTHIAWALA, M.; BARON, B. W. A comparative study of reducing the extracellular potassium concentration 
in red blood cells by washing and by reduction of additive solution. Transfusion, v. 47, n. 2 , p. 248-250, 2007. 12

83 CID, J.; BERTRAN, L. R. S.; MARTíNEZ, N.; CLAPAROLS, M.; MAYMó, R. M.; L, L. P.; RP, R. P. P. Efficacy in reducing potassium load in irradiated red cell bags with a potassium adsorption filter. Transfusion, v. 48, n. 9, p. 1966-1970, 2008. 12

84 BRUGNARA, C.; CHURCHILL, W. H. Effect of irradiation on red cell cation content and transport. Transfusion, v. 32, n. 3, p. 246-252, 1992.12

85 TYNNGÅRD, N.; STUDER, M.; LINDAHL, T. L.; TRINKS, M.; BERLIN, G. The effect of gamma irradiation on the quality of apheresis platelets during storage for 7 days. Transfusion, v. 48, n. 8, p. 1669-1675, 2008. 12

86 DE VRIES, A.; HOLZBERGER, P.; KUNC, M.; HENGSTER, P. Influence of irradiation on neutrophilic granulocyte function. Cancer, v. 92, n. 9, p. 2444-2450, 2001. 12

87 ZIMMERMANN, R.; SCHMIDT, S.; ZINGSEM, J.; GLASER, A.; WEISBACH, V.; RUF, A.; R, R. E. Effect of gamma radiation on the in vitro aggregability of WBC-reduced apheresis platelets. Transfusion, v. 41, n. 2, p. 236-242, 2001. 12

88 ANZSBT, Australian Red Cross Blood and NZBLOOD. Guidelines For Prevention of Transfusion-Associated Graft-versus-Host Disease. Sydney, Austrália, 2011. 12, 14, 102, 106

89 HAIDENBERGER, A.; HENGSTER, P.; KUNC, M.; MICKE, O.; WOLFGRUBER, T.; AUER, T.; LUKAS, P.; DEVRIES, A. Influence of fractionated irradiation on neutrophilic granulocyte function. Strahlentherapie und Onkologie, v. 179, n. 1, p. 45-49, 2003. 12

90 SLICHTER, S. J.; DAVIS, K.; ENRIGHT, H.; BRAINE, H.; GERNSHEIMER, T.; KAO, K.-J.; KICKLER, T.; LEE, E.; MCFARLAND, J.; MCCULLOUGH, J.; RODEY, G.; SCHIFFER, C. A.; WOODSON, R. Factors affecting posttransfusion 
platelet increments, platelet refractoriness, and platelet transfusion intervals in thrombocytopenic patients. Blood, v. 105, n. 10, p. 4106-4114, 2005. 12

91 VAN DER MEER, P. F.; PIETERSZ, R. N. Gamma irradiation does not affect 7-day storage of platelet concentrates. Vox Sanguinis, v. 89, n. 2, p. 97-99, 2005. 12

92 LEITMAN, S. F. Dose, dosimetry, and quality improvement of irradiated blood components. Transfusion, v. 33, p. 447-449, 1993. 13, 55, 93, 95, 106

93 ROSEN, N. R.; WEIDNER, J. G.; BOLDT, H. D.; ROSEN, D. S. Prevention of transfusion-associated graft-versus-host disease: Selection of an adequate dose of gamma irradiation. Transfusion, v. 33, n. 2, p. 125-127, 1993. 13

94 TASWELL, C. Limiting dilution assays for the determination of immunocompetent cell frequencies. Journal of Immunology, v. 126, p. 1514-1518, 1981. 13

95 GÓES, E. G.; BORGES, J. C.; COVAS, D. T.; OREllanA, M. D.; PALMA, P. V.; MORAIS, F. R.; PELÁ, C. A. Quality control of blood irradiation: Determination T cells radiosensitivity to cobalt-60 gamma rays. Transfusion, v. 46, n. 1, p. $34-40,2006.13,55,93,95$

96 BCSH. Blood Transfusion Task Force. [S.1.], 2010. Disponível em: <http://www.bcshguidelines.com/documents/irrad_bcsh_072010.pdf>. 14, 102, 106

97 PINEDA, A.; MCCUllough, J.; BENJAMIN, R. J.; CABLE, R.; STRAUSS, R. G.; BURGSTALER, E.; PORTER, S.; LIN, L.; METZEL, P.; MG, M. G. C.; SPRINT Study Group. Pathogen inactivation of platelets with a photochemical treatment with amotosalen $\mathrm{HCl}$ and ultraviolet light: process used in the SPRINT trial. Transfusion, v. 46, n. 4, p. 562-571, 2006. 14

98 FAST, L. D.; DILEONE, G.; MARSCHNER, S. Inactivation of human white blood cells in platelet products after pathogen reduction technology treatment in comparison to gamma irradiation. Transfusion, v. 51, n. 7, p. 1397-1404, 2011. 14 
99 CUI, Z.; HUANG, Y.; MO, Q.; WANG, X.; QIAN, K. Inactivation of lymphocytes in blood products using riboflavin photochemical treatment with visible light. Transfusion, v. 84, n. 5, p. 1195-1200, 2008. 14

100 DEEG, H. J.; GRAHAM, T. C.; GERHARD-MILLER, L.; APPELBAUM, F. R.; SCHUENING, F.; STORB, R. Prevention of transfusion-induced graftversus-host disease in dogs by ultraviolet irradiation. Blood, v. 74, n. 7, p. 2592-2595, 1989. 14

101 MARSCHNER, S.; FAST, L. D.; BALDWIN, W. M.; SLICHTER, S. J.; GOODRICH, R. P. White blood cell inactivation after treatment with riboflavin and ultraviolet light. Transfusion, v. 50, n. 11, p. 2489-2498, 2010. 14

102 LIN, L.; CORASH, L.; OSSELAER, J. C. Protection against TA-GVHD in platelet transfusion by pathogen inactivation with the INTERCEPT blood system $^{T M}$ - gamma irradiation is not the only answer. Haematologica, v. 95, n. Extra 1, p. 86-93, 2010. 14

103 Sullivan, M. T.; COTTEN, R.; READ, E. J.; WAllaCE, E. L. Blood collection and transfusion in the United States in 2001. Transfusion, v. 47, n. 3, p. 385-394, 2007. 14

104 KING, K. E.; NESS, P. M. How do we prevent transfusion-associated graft-versus-host disease in children? Transfusion, v. 51, n. 5, p. 916-920, 2011. 14

105 GILBERT, C. W.; LAJTHA, L. G. A beta-ray extracorporeal irradiator. Physics in Medicine and Biology, v. 11, n. 2, p. 281-285, 1966. 14

106 BIRKELAND, S. A. The immunosuppressive effect of extracorporeal irradiation of the blood using a portable ${ }^{90} \mathrm{Sr}-90 \mathrm{Y}$ source and small transit doses. Scandinavian Journal of Immunology, v. 5, n. 4, p. 323-329, 1976. 14

107 COVAS, D. T.; JÚNIOR, D. M. L.; BORDIN, J. O. Hemoterapia Fundamentos e Prática. Brasil: Atheneu, 2007. 15 
108 MHATRE, S. G. V.; SHINDE, S. H. Importance of sample rotation in BI-2000 during irradiation for dose uniformity improvement. International Journal of Pharm Tech Research, v. 2, n. 3, p. 1670-1673, 2010. 15

109 JANKOVICH, J. P. Overview of the US Nuclear Regulatory Commission's initiatives on the use of cesium-137 chloride sources. 2010. Disponível em: <http://www.nrc.gov/public-involve/conference-symposia/ric/past/2010/slides/ w11jankovichjpv.pdf $>$. 15

110 MINTZ, P. D. Cesium cessation? An advantage of pathogen reduction treatments. Transfusion, v. 51, n. 7, p. 1369-1376, 2011. 15

111 DODD, B.; VETTER, R. J. Replacement of 137Cs irradiators with x-ray irradiators. Health Physics, v. 96, n. 2, p. S27-S30, 2009. 16

112 AABB. Nuclear Regulatory Commission public meeting on cesium chloride uses, including blood irradiators. 2008. Disponível em: <http://www.aabb.org/events/government/public/Pages/ nrcmeeting092908.aspx >. 16

113 GÓES, E. G.; NICOLUCCI, P.; NALI, I. C.; PELÁ, C. A.; BRUçO, J. L.; BORGES, J. C.; COVAS, D. T. Study of the spatial distribution of the absorbed dose in blood volumes irradiated using a teletherapy unit. Radiation Physics and Chemistry, v. 79, p. 673-677, 2010. 17

114 BOGNER, L.; HARTL, P.; SCHERER, J.; TREUTWEIN, M.; HERBST, M. Dosimetry of blood irradiator. Strahlentherapie und Onkologie, v. 174, n. 8, p. 431-436, 1998. 17

115 HILlyER, C. D.; HALL, J. M.; LACKEY, D. A.; WAZER, D. E. Developmento of colorimetric dosimeter for quality control of blood units and irradiators. Transfusion, v. 33, n. 11, p. 898-901, 1993. 17

116 FEINSTEIN, C.; WINKLER, E.; SARAVI, M. ESR/alanine gamma dosimetry in the 10-30 Gy range. Applied Radiation and Isotopes, v. 52, n. 5, p. 1195-1196, 2000. 17 
117 CHEUnG, T.; BUTSON, M.; YU, P. K. N. Validation of blood product irradiation doses. Physics in Medicine and Biology, v. 46, p. N241-N244, 2001. 17 118 ATTIX, F. H. Introduction to Radiological Physics and Radiation Dosimetry. $2^{a}$. ed. New York, NY, EUA: John Wiley \& Sons, 1986. 18, 20, 21, 48, 50, 55, 87, 100

119 ICRU No. 33. Radiation Quantities and Units. Bethesda, MD, EUA, 1980. 18,68

120 JOHnS, H. E.; CUNnINGHAM, J. R. The Physics of Radiology. $4^{a}$. ed. Springfield, IL, EUA: Charles C. Thomas, 1983. 19, 27, 55

121 ISO/ASTM. 51261. Guide for selection and calibration dosimetry systems for radiation processing. [S.1.], 2002. 19

122 MA, C. M.; ROGERS, D. W.; SHORTT, K. R.; ROSS, C. K.; NAHUM, A. E.; BIELAJEW, A. F. Wall-correction and absorbed-dose conversion factors for Fricke dosimetry: Monte Carlo calculations and measurements. Medical Physics, v. 20, n. 2 , p. $283-292,1993.19$

123 ROSS, C. K.; KLASSEN, N. V.; SHORTT, K. R.; SMITH, G. D. A direct comparison of water calorimetry and Fricke dosimetry. Physics in Medicine and Biology, v. 34, n. 1, p. 23-42, 1989. 19

124 BERO, M.; ZAHILI, M. Radiochromic gel dosimeter (FXG) chemical yield determination for dose measurements standardization. Journal of Physics: Conference Series, v. 164, n. 1, p. 012011, 2009. 19, 25, 52, 68

125 KHAN, F. M. The Physics of Radiation Therapy. $4^{a}$. ed. Philadelphia, PA, EUA: Lippincott Williams \& Wilkins, 2009. 20, 55

126 FRICKE, H.; MORSE, S. The chemical action of roentgen rays on dilute ferrosulphate solutions as a measure of dose. American Journal of Roentgenology, Radium Therapy, and Nuclear Medicine, v. 18, p. 430-432, 1927. 20 
127 GORE, J. C.; KANG, Y. S.; SCHULZ, R. J. Measurement of radiation dose distributions by nuclear magnetic resonance (NMR) imaging. Physics in Medicine and Biology, v. 29, n. 10, p. 1189-1197, 1984. 20, 22, 25

128 BERO, M. A.; GILBOY, W. B.; GLOVER, P. M.; KEDDIE, J. L.

Three-dimensional radiation dose measurements with ferrous benzoic acid xylenol orange in gelatin gel and optical absorption tomography. Nuclear Instruments and Methods in Physics Research A, v. 422, p. 617-620, 1999. 20, 21

129 FRICKE, H.; HART, E. J. Radiation dosimetry. In: - Radiation Dosimetry. New York, NY EUA: Academic Press, 1955. v. 2, cap. Chemical Dosimetry, p. 167-239. 20, 68

130 CAldeirA, A. M. F.; NetO, A. M.; BEnTO, A. C.; BAESSO, M. L.; SILVA, M. A.; ALMEIDA, A. de. Behavior of oxidation in the radiochromic gel dosimeter through photoacoustic technique measurements. Applied Radiaton and Isotopes, v. 65, p. 605-609, 2007. 20, 25

131 GIBNEY, M. J.; LANHAM-NEW, S. A.; CASSIDY, A.; VORSTER, H. H. Introduction to Human Nutrition. $2^{a}$. ed. Chichester, West Sussex, Reino Unido: Wiley-Blackwell, 2009. 20

132 SCHREINER, L. J. Review of Fricke gel dosimeters. Journal of Physics: Conference Series, v. 3, p. 9-21, 2004. 20

133 DAY, M. J.; STEIN, G. Chemical effects of ionizng radiation in some gels. Nature, v. 166, p. 146-147, 1950. 21

134 ANDREW, H. L.; MURPHY, R. E.; LEBRUN, E. J. Gel dosimeter for depth dose measurements. Review of Scientific Instruments, v. 28, n. 5, p. 329-332, 1957. 21

135 IBBOTT, G. S. Applications of gel dosimetry. Journal of Physics: Conference Series, v. 3, p. 58-77, 2004. 22 
136 OLSSON, L. E.; PETERSSON, S.; AHLGREN, L. Ferrous sulphate gels for determination of absorbed dose distributions using MRI technique: Basic studies. Physics in Medicine and Biology, v. 34, p. 43-52, 1989. 22, 25, 71

137 APPLEBY, A.; LEGHROUZ, A. Imaging of radiation dose by visible color development in ferrous-agarose-xylenol orange gels. Medical Physics, v. 18, p. 309-312, 1991. 22, 23, 65, 76, 83

138 GAMBARINI, G.; GOMARASCA, G.; MARCHESINI, R.; PECCI, A.; PIROLA, L.; TOMATIS, S. Three-dimensional determination of absorbed dose by spectrophotometric analysis of ferrous-sulphate agarose gel. Nuclear Instruments and Methods in Physics Research A, v. 422, p. 643-648, 1999. 22, 25

139 LEONG, L. H.; KANDAIYA, S.; SENG, N. B. Characterisation of a Ferrous Agarose Xylenol (FAX) gel for radiotherapy dose measurement. Australasian Physical Ef Engineering Sciences In Medicine, v. 30, n. 2, p. 135-140, 2007. 22

140 HAZLE, J. D.; HEFNER, L.; NYERICK, C. E.; WILSON, L.; BOYER, A. L. Dose-response characteristics of a ferrous-sulphate-doped gelatin system for determining radiation absorbed dose distributions by magnetic resonance imaging (Fe MRI). Physics in Medicine and Biology, v. 36, n. 8, p. 1117-1125, 1991. 22, 25

141 HEALY, B.; ZAHMATKESH, M. H.; NITSCHKE, K. N.; BALDOCK, C. Effect of saccharide additives on response of ferrous-agarose-xylenol orange radiotherapy gel dosimeters. Medical Physics, v. 30, n. 9, p. 2282-2291, 2003. 22

142 DAY, M. J. Radiation dosimetry using nuclear magnetic resonance: an introductory review. Physics in Medicine and Biology, v. 35, n. 12, p. 1605-1609, 1990. 22, 52

143 VITI, V.; D'ERrICO, F.; PACILIO, M.; LUCIANI, A. M.; PALMA, A.; GRANDE, S.; RANGHIASCI, C.; ADORANTE, N.; GUIDONI, L.; ROSI, A.; RANADE, M.; PASQUALE, F. de; BARONE, P.; SEBASTIANI, G. Optical imaging of dose distributions in Fricke gels. Radiation Protection Dosimetry, v. 120, n. $1-4$, p. $148-150,2006.22,36,86$ 
144 GUPTA, B. L. Low level dosimetric studies with the $\mathrm{FeSO}_{4}$-Benzoic Acid-Xylenol Orange system. In: IAEA-SM 160. [S.l.: s.n.], 1972. p. 421-432. 22 145 GUPTA, B. L.; NARAYAN, G. R. G(Fe $\left.{ }^{3+}\right)$ values in the FBX dosemeter. Physics in Medicine and Biology, v. 30, n. 4, p. 337-340, 1985. 23, 26

146 BERO, M. A.; KHARITA, M. H. Effects of ambient temperature on the FXG radiochromic gels used for 3-D dosimetry. Journal of Physics: Conference Series, v. 3 , p. 236-239, 2004. 23, 24, 25, 70

147 LEPAGE, M.; JORDAN, K. 3D dosimetry fundamentals: gels and plastics. Journal of Physics: Conference Series, v. 250, n. 1, 2010. 23, 26

148 TARTE, B. J.; DOORN, T. van. Absorbance measurement with a HeliumNeon laser for chemical dosimetry. Australasian Physical \& Engineering Sciences In Medicine, v. 16, n. 2, p. 75-78, 1993. 23, 49, 65

149 RAE, W. I. D.; WILLEMSE, C. A.; LöTTER, M. G.; ENGELBRECHT, J. S.; SWARTS, J. C. Chelator effect on ion diffusion in ferrous-sulfate-doped gelatin gel dosimeters as analyzed by MRI. Medical Physics, v. 23, n. 15, p. 15-23, 1996. 23, 36

150 CALDEIRA, A. M. F.; ALMEIDA, A. de; NETO, A. M.; BAESSO, M. L.; BENTO, A. C.; SILVA, M. A. Fricke Xylenol Gel characterization using photoacustic technique. Nuclear Instruments and Methods in Physics Research A, v. 582, p. $484-488,2007.24,25$

151 DEWHURST, H. A. Effect of aliphatic alcohols on the $\gamma$-ray oxidation of aerated aqueous ferrous sulphate. Transactions of the Faraday Society, v. 48, p. 905-911, 1952. 23

152 DAVIES, J. V.; LAW, J. Practical aspects of ferrous sulphate dsimetry. Physics in Medicine and Biology, v. 8, n. 1, p. 91-96, 1963. 23, 148

153 BERO, M. A.; GILBOY, W. B.; GLOVER, P. M. An optical method for three-dimensional dosimetry. Journal of Radiological Protection, v. 20, p. 287-294, 2000. 24, 46, 66, 69 
154 BERO, M. A.; GILBOY, W. B.; GLOVER, P. M. Radiochromic gel dosemeter for three-dimensional dosimetry. Radiation Physics and Chemistry, v. 61, p. 433-435, 2001. 24, 25

155 BABIC, S.; BATTISTA, J.; JORDAN, K. Three-dimensional dose verification for intensity-modulated radiation therapy in the radiological physics centre head-and-neck phantom using optical computed tomography scans of ferrous xylenol-orangegeldosimeters. International Journal of Radiation Oncology, Biology, Physics, v. 70, n. 4, p. 1281-1291, 2008. 24

156 OLIVEIRA, L. N. D.; ZIMMERMAN, R. L.; MOREIRA, M. V.; ILA, D.; ALMEIDA, A. D. Determination of diffusion coefficient in Fricke Xylenol Gel dosimeter after electron beam bombardment. Surface and Coatings Technology, v. 2003, n. 17-18, p. 2367-2369, 2009. 24, 26

157 GAMBARINI, G.; BIRATTARI, C.; MARIANI, M.; MARCHESINI, R.; PIROlA, L.; PRESTINI, P.; SELlA, M.; TOMATIS, S. Study of light transmittance from layers of Fricke-xylenol-orange-gel dosimeters. Nuclear Instruments and Methods in Physics Research B, v. 213, p. 321-324, 2004. 24, 25

158 COSTA, R. T. Avaliando a viabilidade do uso do dosímetro Fricke modificado na radioterapia. Ribeirão Preto, SP, Brasil, 2001. 25

159 AUSTERlitZ, C.; MOTA, H. C.; SEMPAU, J.; BENHABIB, S. M.; CAMPOS, D.; Allison, R.; AlmeIDA, C. E. de; ZHU, D.; SIBATA, C. H. Determination of absorbed dose in water at the reference point $\mathrm{d}\left(r_{0}, \theta_{0}\right)$ for an ${ }^{192} \mathrm{Ir}$ HDR brachytherapy source using a Fricke system. Medical Physics, v. 35, n. 12, p. 5360-5365, 2008. 25

160 KEALL, P.; BALDOCK, C. A theoretical study of the radiological properties and water equivalence of fricke and polymer gels used for radiation dosimetry. Australasian Physical 8 Engineering Sciences In Medicine, v. 22, n. 3, p. 85-91, 1999. 25 
161 DAVIES, J. B.; BALDOCK, C. Temperature dependence on the dose response of the Fricke-Gelatin-Xylenol Orange Gel dosimeter. Radiation Physics and Chemistry, v. 79, n. 5, p. 660-662, 2010. 25, 82, 83

162 OliveirA, L. N. D.; CALCINA, C. S.; PARADA, M. A.; ALMEIDA, C. E. D.; ALMEIDA, A. D. Ferrous Xylenol Gel measurements for 6 and $10 \mathrm{MV}$ photons in small field sizes. Brazilian Journal of Physics, v. 37, n. No. 3B, p. 1141-1145, 2007. 25

163 SATO, R.; ALMEIDA, A. de; MOREIRA, M. V. ${ }^{137}$ Cs source dose distribution using the Fricke Xylenol Gel dosimetry. Nuclear Instruments and Methods in Physics Research B, v. 267, p. 842-845, 2009. 25

164 BERO, M. A.; ABUKASSEM, I. Detection of ultraviolet radiation using tissue equivalent radiochromic gel materials. Journal of Physics: Conference Series, v. $164,2009.25$

165 ABUKASSEM, I.; BERO, M. A. Application of radiochromic gel detector (FXG) for UVA dose measurements. Radiation Physics and Chemistry, v. 79, p. 1209-1214, 2010. 25

166 KRON, T.; METCALFE, P.; POPE, J. M. Investigation of the tissue equivalence of gels used for NMR dosimetry. Physics in Medicine and Biology, v. 38 , p. $139-150,1993.25$

167 BERO, M. A. Dosimetric properties of a radiochromic gel detector for diagnostic X-rays. Nuclear Instruments and Methods in Physics Research A, v. 580, p. 186-189, 2007. 25, 83, 146

168 CAlCinA, C. S. G.; OLIVEIRA, L. N. de; AlMEIDA, C. E. de; ALMEIDA, A. de. Dosimetric parameters for small field sizes using Fricke Xylenol Gel, thermoluminescent and film dosimeters, and an ionization chamber. Physics in Medicine and Biology, v. 52, p. 1431-1439, 2007. 25

169 GAMBARINI, G.; ARRIGONI, S.; CANTONE, M. C.; MOLHO, N.; FACCHIELLI, L.; SICHIROLLO, A. E. Dose-response curve slope improvement 
and result reproducibility of ferrous-sulphate-doped gels analysed by NMR imaging. Physics in Medicine and Biology, v. 39, n. 4, p. 703-717, 1994. 25

170 VERGOTE, K.; DEENE, Y. D.; DUThoY, W.; GERSEM, W. D.; NEVE, W. D.; ACHTEN, E.; WAGTER, C. D. Validation and application of polymer gel dosimetry for the dose verification of an intensity-modulated arc therapy (IMAT) treatment. Physics in Medicine and Biology, v. 49, n. 2, p. 287-305, 2004. 25

171 WOlODZKO, J. G.; MARSDEN, C.; APPLEBY, A. CCD imaging for optical tomography of gel radiation dosimeters. Medical Physics, v. 26, n. 11, p. 2508-2513, 1999. 25

172 DORAN, S. J.; KOERKAMP, K. K.; BERO, M. A.; JENNESON, P.; MORTON, E. J.; GILBOY, W. B. A CCD-based optical CT scanner for high resolution 3D imaging of radiaiton distributions: equipment specifications, optical simulations and preliminary results. Physics in Medicine and Biology, v. 46, n. 12, p. $3191-3214,2001.25$

173 CZElusniAK, C.; DEL LAMA, L. S.; MOREIRA, M. V.; ALMEIDA, A. D. Evaluation of the breast absorbed dose distribution using the Fricke Xylenol Gel. Journal of Physics: Conference Series, v. 250, n. 1, 2010. 25

174 SAMPAIO, F. G. A.; DEL LAMA, L. S.; MOREIRA, M. V.; ALMEIDA, A. de. Gap application results for adjacent electron beams treatment. Nuclear Instruments and Methods in Physics Research B, v. 269, n. 24, p. 3141-3144, 2011. 25

175 BALDOCK, C.; HARRIS, P. J.; PIERCY, A. R.; HEALY, B. Experimental determination of diffusion coefficients in two-dimensions in ferrous sulphate gels using the finite element method. Australasian Physical $\&$ Engineering Sciences In Medicine, v. 24, n. 1, p. 19-30, 2001. 25

176 SCHREINER, L. J. Fricke gel dosimetry. Proceedings of the $2^{\text {th }}$ International Conference on Gel Dosimetry, DOSGEL 2001, p. 15-22, 2002. 25 
177 MARYANSKI, M. J.; IBBOTT, G. S.; EASTMAN, P.; SHULZ, R. J.; GORE, J. C. Radiation therapy dosimetry using magnetic resonance imaging of polymer gels. Medical Physics, v. 23, n. 5, p. 699-705, 1996. 25

178 BALDOCK, C.; BUlFORD, R. P.; BIllinghAM, N. C.; WAGNER, G. S.; PATVAL, S.; BADAWI, R. D.; KEEVIL, S. F. Experimental procedure for the manufacture of polyacrylamide gel (PAG) for magnetic resonance imaging (MRI) radiation dosimetry. Physics in Medicine and Biology, v. 43, n. 3, p. 695-702, 1998. 25

179 FOnG, P. M.; KEIL, D. C.; DOES, M. D.; GORE, J. C. Polymer gels for magnetic resonance imaging of radiation dose distribution at normal room atmosphere. Physics in Medicine and Biology, v. 46, n. 12, p. 3105-3113, 2001. 25

180 GUSTAVsson, H.; KARLSSON, A.; BÄCK, S. A.; OlSSON, L. E.; P, P. H.; ENGSTRÖM, P.; NYSTRÖM, H. MAGIC-type polymer gel for three-dimensional dosimetry: intensity-modulated radiation therapy verification. Medical Physics, v. 30, n. 6 , p. $1264-1271,2003.25$

181 TSENG, Y.; HUANG, S. C.; CHU, W. An image-based approach to measure the ferric ion diffusion coefficient in fricke gel dosimetry. Annual International Conference of the IEEE Engineering in Medicine and Biology Society, v. 7, p. 7393-7396, 2005. 26

182 SHANI, G. Radiation Dosimetry: Instrumentation and Methods. $2^{a}$. ed. [S.l.]: CRC Press, 2000. 27

183 BURCH, S. E.; KEARFOTT, K. J.; TRUEBLOOD, J. H.; SHEILS, W. C.; YEO, J. I.; WANG, C. K. C. A new approach to film dosimetry for high energy photon beams: Lateral scatter filtering. Medical Phys, v. 24, n. 5, p. 775-783, 1997. 27

184 WILLIAMSON, J. F. Film dosimetry of megavoltage photon beams: A practical method of isodensity-to-isodose curve conversion. Medical Phy, v. 8, n. 1, p. $94-98,1981.27$ 
185 BOUCHARD, H.; LACROIX, F.; BEAUDOIN, G.; CARRIER, J.-F.;

KAWRAKOW, I. On the characterization and uncertainty analysis of radiochromic film dosimetry. Medical Physics, v. 36, n. 6, p. 1931-1946, 2009. 28

186 CHIU-TSAO, S. T.; DE LA ZERDA, A.; LIN, J.; KIM, J. H. High-sensitivity GafChromic film dosimetry for ${ }^{125}$ I seed. Medical Physics, v. 21, n. 5, p. 651-657, 1994. 28

187 NIROOMAND-RAD, A.; BLACKWELL, C. R.; COURSEY, B. M.; GALL, K. P.; GALVIN, J. M.; MCLAUGHLIN, W. L.; MEIGOONI, A. S.; NATH, R.; RODGERS, J. E.; SOARES, C. G. Radiochromic film dosimetry: Recommendations of AAPM radiation therapy committee task group 55. Medical Physics, v. 25, n. 11, p. 2093-2115, 1998. 28, 94

188 BUTSON, M. J.; YU, P. K. N.; CHEUnG, T.; METCALFE, P. Radiochromic film for medical radiationd dosimetry. Materials Science and Engineering, v. 41, p. 61-120, 2003. 28

189 SU, F. C.; LIU, Y.; STATHAKIS, S.; SHI, C.; ESQUIVEL, C.; PAPANIKOLAOU, N. Dosimetry characteristics of GAFCHROMIC EBT film responding to therapeutic electron beams. Applied Radiation and Isotopes, v. 65, n. 10, p. $1187-1192,2007.28$

190 WILCOX, E. E.; DASKALOV, G. M. Accuracy of dose measurements and calculations within and beyond heterogeneous tissues for $6 \mathrm{MV}$ photon fields smaller than $4 \mathrm{~cm}$ produced by Cyberknife. Medical Physics, v. 35, n. 6, p. 2259-2266, 2008. 28

191 TOMIC, N.; GOSSELIN, M.; WAN, J. F.; SARAGOVI, U.; PODGORSAK, E. B.; M, M. E.; DEVIC, S. Verification of cell irradiation dose deposition using a radiochromic film. Physics in Medicine and Biology, v. 52, n. 11, p. 3121-3131, 2007. 28

192 FUSS, M.; STURTEWAGEN, E.; WAGTER, C. D.; GEORG, D. Dosimetric characterization of GafChromic EBT film and its implication on film dosimetry 
quality assurance. Physics in Medicine and Biology, v. 52, n. 14, p. 4211-4225, 2007. 28,84

193 DEVIC, S.; TOMIC, N.; SOARES, C. G.; PODGORSAK, E. B. Optimizing the dynamic range extension of a radiochromic film dosimetry system. Medical Physics, v. 36, n. 2, p. 429-437, 2009. 28, 37

194 SALVAT, F.; FERNÁNDEZ-VAREA, J. M.; SEMPAU, J. PENELOPE, a code system for Monte Carlo simulation of electron and photon transport. Barcelona, Espanha, Dezembro 2008. 31

195 ICRU No. 35. Radiation dosimetry: electron beams with energies between 1 and $50 \mathrm{MeV}$. [S.l.], 1984. 36

196 PEDERSEN, T. V.; OLSEN, D. R.; SKRETTING, A. Measurement of the ferric diffusion coefficient in agarose and gelatine gels by utilization of the evolution of a radiation induced edge as reflected in relaxation rate images. Physics in Medicine and Biology, v. 42, n. 8, p. 1575-1585, 1997. 36

197 SAMPAIO, F. G. A.; DEL LAMA, L. S.; SATO, R.; DE OLIVEIRA, D. M. M.; CZELUSNIAK, C.; DE OLIVEIRA, L. N.; DE ALMEIDA, A. Quality assurance of a two-dimensional CCD detector system applied in dosimetry. IEEE Transactions on Nuclear Science, v. 60, n. 2, p. 810-816, 2013. 37, 64, 86

198 HILTS, M.; JIRASEK, A. Adaptive mean filtering for noise reduction in CT polymer gel dosimetry. Medical Physics, v. 35, n. 1, p. 344-355, 2008. 37

199 IAEA. Absorbed Dose Determination in External Beam Radiotherapy: An International Code of Practice for Dosimetry Based on Standars of Absorbed Dose To Water. Technical Reports Series 398. Viena, Áustria, 2000. 44, 55, 56

200 Resolução CNEN No 130/12. Requisitos de Segurança e Proteção Radiológica para Serviços de Radioterapia. [S.1.], 2012. Disponível em: <http://www.cnen.gov.br/seguranca/normas/mostra-norma.asp?op=306>. 44

201 CNEN-NE-3.06. Requisitos de Radioproteção e Segurança para Serviços de Radioterapia. Rio de Janeiro, RJ, Brasil, 1990. 44 
202 HEALY, B.; BRINDHA, S.; ZAHMATKESH, M.; BALDOCK, C.

Characterisation of the ferrous-xylenol orange-gelatin (FXG) gel dosimeter. Journal of Physics: Conference Series, v. 3, p. 142-145, 2004. 46, 146

203 INMETRO. Vocabulário Internacional de Metrologia: conceitos fundamentais e gerais e termos associados (VIM 2008). 1a Edição Brasileira. Rio de Janeiro, RJ, Brasil, 2009. 48, 49, 50, 61

204 SVENSSON, H.; BRAHME, A. Ferrous sulphate dosimetry for electrons. Acta Radiologica Oncology, v. 18, p. 326-336, 1979. 48, 68

205 KLASSEN, N. V.; SHORTT, K. R.; SEUNTJEnS, J.; ROSS, C. K. Fricke dosimetry: the difference between $\mathrm{G}\left(\mathrm{Fe}^{+3}\right)$ for ${ }^{60} \mathrm{Co} \gamma$-rays and high-energy x-rays. Physics in Medicine and Biology, v. 44, n. 7, p. 1609-1624, 1999. 49, 148

206 CAVINATO, C. C.; CAMPOS, L. L. Study of Fricke gel dosimeter response for different gel quality. Journal of Physics: Conference Series, v. 249, 2010. 51

207 CAvinato, C. C.; SAKuraBA, R. K.; CRUZ, J. C.; CAMPOS, L. L. Optical response of the FXG solution to different phantom materials. Radiation Measurements, v. 46, n. 12, p. 1928-1931, 2011. 52

208 BRADY, S. L.; TONCHEVA, G.; DEWHIRST, M. W.; YOSHIZUMI, T. T. Characterization of a $137 \mathrm{Cs}$ irradiator from a new perspective with modern dosimetric tools. Health Physics, v. 97, n. 3, p. 195-205, 2009. 54

209 ICRU No. 46. Photon, Electron, Proton and Neutron Interaction Data for Body Tissues (Report 46). Bethesda, MD, EUA, 1992. 54, 92

210 WHITE, D. R. Tissue substitutes in experimental radiation physics. Medical Physics, v. 5, n. 6, p. 467-479, 1978. 54

211 PODGORSAK, E. B. Radiation Oncology Physics: A handbook for teachers and students. Viena, Áustria: International Atomic Energy Agency, 2005. 55, 56, 95

212 ICRU No. 44. Tissue Substitutes in Radiation Dosimetry and Measurement (Report 44). Bethesda, MD, EUA, 1989. 55, 90, 92, 93, 95 
213 GÓES, E. G.; COVAS, D. T.; HADDAD, R.; PELÁ, C. A.; FORMIGONI, C. E.; BORGES, J. C. Quality control system for blood irradiation using teletherapy unit. Vox Sanguinis, v. 86, p. 105-110, 2004. 55, 93, 95

214 ISO/ASTM. 51939. Standard Practice for Blood Irradiation Dosimetry. [S.I.], 2005. 55,94

215 NIST. X-Ray Mass Attenuation Coefficients. 2010. Disponível em: <http://physics.nist.gov/PhysRefData/XrayMassCoef/tab4.html>. 55, 93, 94, 95

216 YU, C.; LUXTON, G. TLD dose measurement: A simplified accurate technique for the dose. Medical Physics, v. 26, n. 6, p. 1010-1016, 1999. 56

217 DEWERD, L. A.; CAMERON, J. R.; DA-KE, W.; PAPINI, T.; DAS, I. J. Characteristics of a new dosemeter material: $\mathrm{LiF}(\mathrm{Mg}, \mathrm{Cu}, \mathrm{P})$. Radiation Protection Dosimetry, v. 6, n. 1-4, p. 350-352, 1983. 57

218 KRON, T.; DUGGAN, L.; SMITH, T.; ROSENFELD, A.; BUTSON, M.; KAPLAN, G.; HOWLETT, S.; HYODO, K. Dose response of various radiation detectors to synchrotron radiation. Physics in Medicine and Biology, v. 43, n. 11, p. $3235-3259,1998.58$

219 SUtherland, J. G. H.; ROGERS, D. W. O. Monte Carlo calculated absorbed-dose energy dependence of EBT and EBT2 film. Medical Physics, v. 37, n. 3 , p. $1110-1116,2010.58$

220 RINK, A.; VITKIN, I. A.; JAFFRAY, D. A. Intra-irradiation changes in the signal of polymer-based dosimeter (GAFCHROMIC EBT) due to dose rate variations. Physics in Medicine and Biology, v. 52, n. 22, p. N523-529, 2007. 59, 84 221 LYNCH, B. D.; KOZELKA, J.; RANADE, M. K.; LI, J. G.; SIMON, W. E.; DEMPSEY, J. F. Important considerations for radiochromic film dosimetry with flatbed CCD scanners and EBT GAFCHROMIC@ film. Medical Physics, v. 33, n. 12 , p. $4551-4556,2006.59$

222 MeneGotTI, L.; DELANA, A.; MARTiGnAnO, A. Radiochromic film dosimetry with flatbed scanners: A fast and accurate method for dose calibration 
and uniformity correction with single film exposure. Medical Physics, v. 35, n. 7, p. 3078-3085, 2008. 59

223 LEWIS, D.; MICKE, A.; YU, X.; CHAN, M. F. An efficient protocol for radiochromic fim dosimetry combining calibration and measurement in a single scan. Medical Physics, v. 39, n. 10, p. 6339-6350, 2012. 59

224 DEVIC, S.; SEUNTJENS, J.; SHAM, E.; PODGORSAK, E. B.; SCHMIDTLEIN, C. R.; KIROV, A. S.; SOARES, C. G. Precise radiochromic film dosimetry using a flat-bed document scanner. Medical Physics, v. 32, n. 7, p. 2245-2253, 2005. 59

225 VUOLO, J. H. Fundamentos da Teoria de Erros. $2^{a}$. ed. São Paulo, SP Brasil: Edgard Blücher, 1995. 61

226 ISO/ASTM. 5170\%. Estimating Uncertainties in Dosimetry for Radiation Processing. [S.1.], 2005. 61

227 JOINT COMMITTEE FOR GUIDES IN METROLOGY. Evaluation of measurement data - Guide to the expression of uncertainty in measurement. [S.1.], 2008. 61

228 GAY, C.; COLLINS, J.; GEBICKI, J. M. Determination of iron in solutions with the ferric-xylenol orange complex. Analytical Biochemistry, v. 273, p. 143-148, 1999. 66,69

229 DAVIES, J. B.; BALDOCK, C. Sensitivity and stability of the Fricke-GelatinXylenol Orange Gel dosimeter. Radiation Physics and Chemistry, v. 77, n. 6, p. 690-696, 2008. 66, 67, 71, 76

230 MAGEE, J. L.; CHATTERJEE, A. Theory of the chemical effects of high-energy electrons. The Journal of Physical Chemistry, v. 82, n. 20, p. 2219-2226, 1978. 66

231 ATTIX, F. H.; ROESCH, W. C. Radiation Dosimetry. $2^{a}$. ed. New York, NY, EUA: Academic Press, 1966. 69, 83, 85, 147 
232 CAldeirA, A. M. F.; NetO, A. M.; BAESSO, M. L.; BEnTO, A. C.; SILVA, M. A.; ALMEIDA, A. D. Estudo da oxidação natural no dosímetro radiocrômico FXG. Revista Brasileira de Física Médica, v. 2, n. 1, p. 24-27, 2009. 70

233 SKOOG, D. A.; LEARY, J. J. Principles of Instrumental Analysis. $4^{a}$. ed. [S.1.]: Saunders College Publishing, 1992. 75

234 SÖDERGREN, E.; NOUROOZ-ZADEH, J.; BERGLUND, L.; VESSBY, B. Re-evaluation of the ferrous oxidation in xylenol orange assay for the measurement of plasma lipid hydroperoxides. Journal of Biochemical and Biophysical Methods, v. 37 , n. 3 , p. $137-146,1998.76$

235 DEWHURST, H. A. Effect of organic substances on the $\gamma$-ray oxidation of ferrous sulfate. Journal of Chemical Physics, v. 19, p. 1329, 1951. 78

236 MARTÍNEZ, T.; LARTIGUE, J.; RAMOS-BERNAL, S.; RAMOS, A.; MOSQUEIRA, G. F.; NEGRÓN-MENDOZA, A. Iron salts in solid state and frozen solutions as dosimeters for low irradiation temperatures. Applied Radiation and Isotopes, v. 63, n. 5, p. 711-736, 2005. 82

237 JUÁREZ-CALDERÓN, J. M.; NEGRÓN-MENDOZA, A.; RAMOSBERNAL, S. Irradiation of ferrous ammonium sulfate for its use as high absorbed dose and low-temperature dosimeter. Radiation Physics and Chemistry, v. 76, n. 11-12, p. 1829-1832, 2007. 82, 146

238 ISO/ASTM. E1026-04. Standard Practice for Using the Fricke ReferenceStandard Dosimetry System. [S.1.], 2004. 82, 147

239 MATTSSON, L. O.; JOHANSSON, K.-A.; SVENSSON, H. Ferrous sulphate dosemeter for control of ionization chamber dosimetry of electron and ${ }^{60}$ Co gamma beams. Acta Oncologica, v. 21, n. 2, p. 139-144, 1982. 82

240 SHORTT, K. R. The temperature dependence of $\mathrm{G}\left(\mathrm{Fe}^{+3}\right)$ for the Fricke dosemeter. Physics in Medicine and Biology, v. 34, p. 1923-1926, 1989. 82 
241 KARSCH, L.; BEYREUTHER, E.; BURRIS-MOG, T.; KRAFT, S.;

RICHTER, C.; ZEIL, K.; PAWELKE, J. Dose rate dependence for different dosimeters and detectors: TLD, OSL, EBT films, and diamond detectors. Medical Physics, v. 39, n. 5, p. 2447-2455, 2012. 84

242 VANDANA, S.; SHAIJU, V. S.; SHARMA, S. D.; MHATRE, S.; SHINDE, S.; CHOURASIYA, G.; MAYYA, Y. S. Dosimetry of gamma chamber blood irradiator using Gafchromic EBT film. Applied Radiation and Isotopes, v. 69, n. 1, p. 130-135, 2011. $91,94,95$

243 FEARON, T.; CRISS, V. R.; LUBAN, N. L. C. Blood irradiator dosimetry with BANG polymer gels. Transfusion, v. 45, p. 1658-1662, 2005. 92

244 Butson, M. J.; ChEUnG, T.; YU, P. K. N.; STOKES, M. J. Blood irradiation with accelerator produced electron beams. Physics in Medicine and Biology, v. 45, n. 11, p. N139-N142, 2000. 94

245 Ali, M.; TIWARI, P.; KUMAR, A.; MiShrA, K. P.; PANDEY, B. N. Correlation of FBX dosimeter and micronucleus assay in radiation dosimetry of gamma chambers. Journal of Environmental Pathology, Toxicology and Oncology, v. 28 , n. 1, p. $63-73,2009.94$

246 PINNARÒ, P.; SORIANI, A.; D'ALESSIO, D.; GIORDANO, C.; FODDAI, M. L.; PINZI, V.; STRIGARI, L. Implementation of a new cost efficacy method for blood irradiation using a non dedicated device. Journal of Experimental \& Clinical Cancer Research, v. 30, n. 7, 2011. 95, 145

247 ARJOMAnDY, B.; TAILOR, R.; ANAND, A.; SAHOO, N.; GILlin, M.; PRADO, K.; VICIC, M. Energy dependence and dose response of Gafchromic EBT2 film over a wide range of photon, electron, and proton beam energies. Medical Physics, v. 37, n. 5, p. 1942-1947, 2010. 95

248 MeigoOni, A. S.; SAnderS, M. F.; IBBOTT, G. S.; SZEGLIN, S. R. Dosimetric characteristics of an improved radiochromic film. Medical Physics, v. 23, n. 11, p. $1883-1888,1996.95$ 
249 RAHN, R. O. Chemical dosimetry using an iodide/iodate aqueous solution: Application to the gamma irradiation of blood. Applied Radiation and Isotopes, v. 58, p. $79-84,2003.97,100$

250 CUTnelL, J. D.; JOHnSOn, K. W. Physics. $4^{a}$. ed. [S.1.]: Wiley, 1998. 98 251 FEARON, T. C.; LUBAN, N. L. Practical dosimetric aspects of blood and blood product irradiation. Transfusion, v. 26, n. 5, p. 457-459, 1986. 100

252 NIST. X-Ray Mass Attenuation Coefficients. 2010. Disponível em: <http://physics.nist.gov/PhysRefData/Star/Text/ESTAR.html>. 100

253 CAStellanO, G.; BRUSA, D.; CARRARA, M.; GAMBARINI, G.; VALENTE, M. An optimized Monte Carlo (PENELOPE) code for the characterization of gel-layer detectors in radiotherapy. Nuclear Instruments and Methods in Physics Research A, v. 580, n. 1, p. 502-505, 2007. 104

254 VAlente, M.; AOn, E.; BRUnetTO, M.; CASTEllanO, G.; GALLIVANONE, F.; GAMBARINI, G. Gel dosimetry measurements and Monte Carlo modeling for external radiotherapy photon beams: Comparison with a treatment planning system dose distribution. Nuclear Instruments and Methods in Physics Research A, v. 580, n. 1, p. 497-501, 2007. 104

255 PERKINS, J. T.; PAPOULIAS, S. A. The effect of loading conditions on dose distribution within a blood irradiator. Transfusion, v. 34, n. S10, p. 75S, 1994. 106 256 LUBAN, N.; FEARON, T.; SF, S. L.; MOROFF, G. Absorption of gamma irradiation in simulated blood components using cesium irradiators. Transfusion, v. 35 , n. S10, p. $63 \mathrm{~S}, 1995.107$

257 PALM, A.; MATTSON, O. Influence of sulphuric acid contaminants on Fricke dosimetry. Physics in Medicine and Biology, v. 45, p. N111-N114, 2000. 146, 148 


\section{Características dos componentes do FXG}

A Tabela A.1 apresenta as principais informações acerca dos componentes utilizados para o preparo do dosímetro Fricke Xilenol Gel (FXG). 


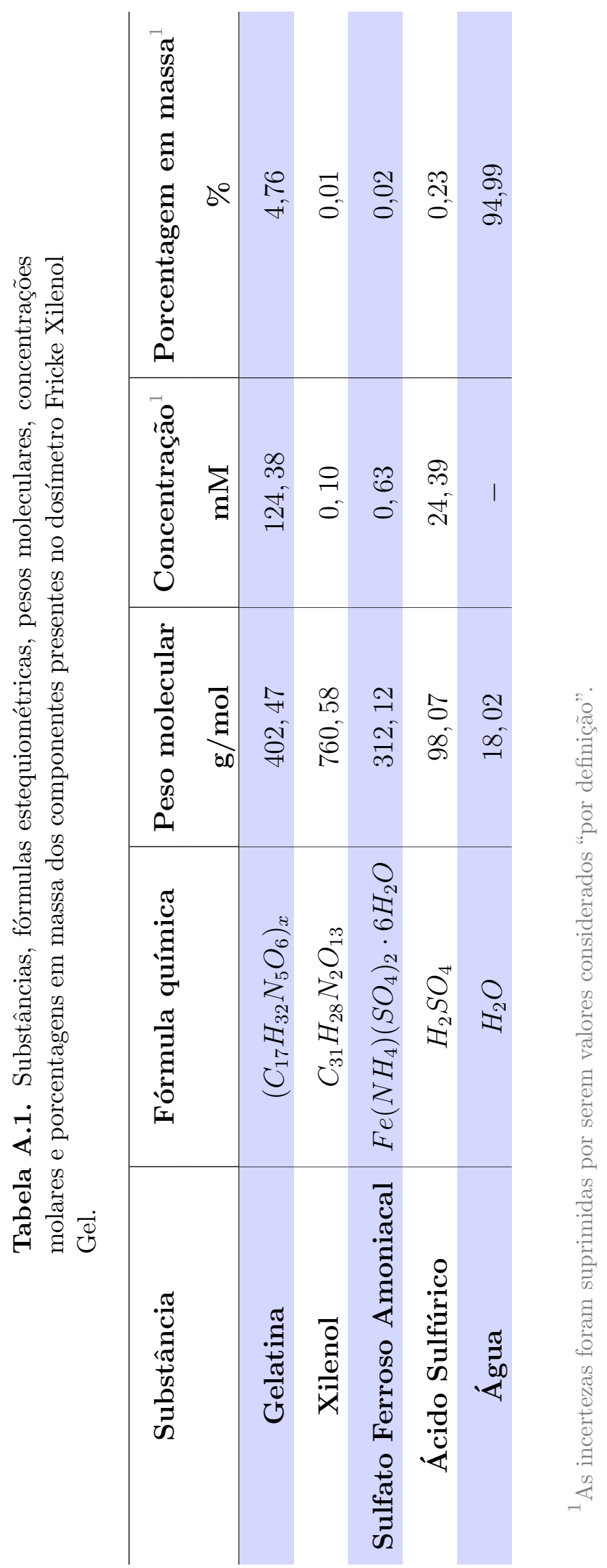




\section{Apêndice}

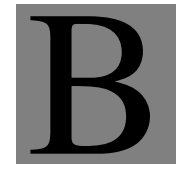

\section{Plano de Controle de Qualidade para a dosimetria da irradiação de sangue}

Além da adaptação do dosímetro FXG para a irradiação de sangue, propõe-se também neste trabalho um plano de controle de qualidade para a dosimetria da irradiação de sangue, que vise garantir que a incerteza propagada satisfaça os requerimentos necessários para as aplicações de irradiações e que apresente rastreabilidade e consistência com os padrões necessários. Além da qualidade dos produtos irradiados, a irradiação e dosimetria realizadas no próprio banco de sangue tendem a ser mais economicamente vantajosas. Estima-se que os custos da irradiação e dosimetria sejam de US\$90,00 dólares e US\$15,00 dólares por bolsa, para procedimentos externos e internos ao banco de sangue, respectivamente [246]. Por fim, os procedimentos quando realizados internamente evitam problemas logísticos, uma vez que os componentes sanguíneos não precisam ser transportados para fora do banco de sangue.

Independentemente do equipamento empregado na irradiação de sangue (irradiadores específicos ou teleterápicos), é necessário estabelecer um procedimento de controle de qualidade para verificar a dose liberada em cada bolsa de sangue. De fato, pelos padrões da $A A B B$ e as recomendações do $F D A$ americano, por exemplo, um controle de qualidade deve ser realizado para validar as irradiações de sangue $[12,13]$. Além disso, para garantir que a dose mínima seja liberada no volume irradiado, recomenda-se a presença de um físico médico ou profissional capacitado 
para realizar a dosimetria do equipamento $[5,6,17]$.

A implementação de um sistema de dosimetria com recursos internos tem a capacidade de diminuir os custos, os problemas de logística e o tempo de procedimento que envolvem a dosimetria da irradiação de sangue. A implementação de um programa de dosimetria exige um sistema de controle consistente e um nível de coerência metrológica compatível com o grau de exigência da Hemoterapia. Portanto, é fundamental que os sistemas metrológico e gerencial de um banco de sangue demostrem um alto nível de qualidade, a fim de garantir a sua credibilidade. Além disso, a rastreabilidade das medidas radiológicas realizadas pelo sistema dosimétrico devem ser regularmente verificada através de um programa de qualidade interno, de auditorias externas e de intercomparações periódicas realizadas anualmente.

Embora o ${ }^{137}$ Cs tenha uma meia vida considerada "longa", sua energia pode ser uma limitação dependendo da geometria e do volume de sangue a serem irradiados. Por conta de possíveis inomogeneidades proporcionadas devido à energia dos fótons, um controle de qualidade deve ser capaz de quantificar e acompanhar as discrepâncias entre a dose prescrita e aquela absorvida pelos hemocomponentes. Assim, a dosimetria deve ser parte integrante do programa de controle de qualidade para garantir que o processo atenda às especificações previamente definidas.

Quanto à dosimetria proposta neste trabalho, seguem algumas recomendações voltadas para seu controle de qualidade. A agitação durante o preparo do dosímetro já é suficiente para garantir a concentração adequada de oxigênio na solução, não havendo a necessidade de borbulhar ar durante a dissolução dos componentes. Outro cuidado essencial ao se preparar dosímetros do tipo Fricke gel está relacionado à qualidade da água utilizada. A pureza da água é uma característica de grande importância, visto que esta é o principal constituinte do dosímetro e, portanto, a principal forma de contaminação. Como os dosímetros químicos ou sistemas de detecção radiativos que empregam análises químicas são bastante sensíveis à impurezas [167], particularmente as de origens orgânica e metálica, o controle das etapas de preparo são cruciais em termos de reprodutibilidade. De fato, impurezas principalmente presentes na gelatina afetam a resposta do sistema [202], embora já tenha sido reportado que impurezas tanto no ácido sulfúrico [257] quanto no sulfato ferroso amoniacal [237] também distorcem a resposta do dosímetro. Água de elevada 
pureza muitas vezes se faz necessária para que o sistema dosimétrico funcione confiavelmente [231]. Resultados presentes na literatura apontam que o gel dosimétrico feito com água Milli-Q apresenta melhor resposta, frente à água deionizada (redução de $5 \%$ em sua sensibilidade, quando comparada à água Milli-Q) e à água comum (redução de 68 \%, quando comparada à água Milli-Q) [1]. Como a água compõe em torno de $95 \%$ do peso do dosímetro FXG, seu controle deve ser sempre levado em consideração. Além disso, deve-se evitar o uso de qualquer instrumento metálico durante o preparo e/ou análise do dosímetro de modo a não contaminar a solução com elementos metálicos que possam alterar a resposta do dosímetro. Fora isso, para toda e qualquer alteração dos componentes presentes no dosímetro FXG (lote, fabricante, etc.), novas curvas de calibração para todo o intervalo de trabalho, $[\approx 0$; 54] Gy, devem ser estabelecidas empregando tanto a espectrofotometria quanto o método por $C C D$.

As vidradrias devem ser lavadas rigorosamente para evitar futuras contaminações. Devem ser limpas com detergente e enxaguadas com água corrente em abundância. Recomenda-se que o último enxágue seja feito com água Milli-Q, a fim de remover resíduos da água corrente, especialmente resíduos metálicos, presentes na tubulação, e de cloro, presente na água. Após utilização, as cubetas irradiadas devem ser colocadas em um forno ou estufa até que a gelatina se liquefaça e a seguir, devem ser mergulhadas em água morna $\left(\approx 40{ }^{\circ} \mathrm{C}\right)$ e enxaguadas com água corrente e/ou Milli-Q.

Os dosímetros do tipo Fricke também são passíveis de oxidarem-se devido à temperatura ambiente (maiores $20-25^{\circ} \mathrm{C}$ ), podendo ser significativa sua influência na resposta do mesmo ${ }^{1}$. As temperaturas tanto durante a irradiação quanto análise devem ser controladas e devem oscilar entre $20-25{ }^{\circ} \mathrm{C}$. Além disso, tais dosímetros são sensíveis à radiação ultra-violeta de modo que não devem ser expostos ao sol ou fontes UV, antes ou após a irradiação. Para iluminação ambiente, nenhum cuidado especial deve ser empregado, embora seja recomendado manter os dosímetros abrigados da luz.

Para ocasiões em que o FXG oxide durante seu preparo, deve-se checar primei-

\footnotetext{
${ }^{1}$ A refrigeração das amostras pode reduzir consideravelmente a oxidação natural do dosímetro, porém ela também pode reduzir a concentração de oxigênio [238].
} 
ramente a qualidade do ácido sulfúrico, em seguida a qualidade da água e, por fim, o sulfato ferroso amoniacal. Um indicativo da qualidade do ácido sulfúrico é o coeficiente linear da curva de calibração do FXG, que deve ser o mais próximo possível de zero. Valores muito diferentes de zero indicam que existem impurezas associadas ao ácido sulfúrico $[152,205]$. De fato, a pureza do ácido sulfúrico pode contribuir em até $5 \%$ de redução do rendimento químico para os íons férricos [257]. Quando o problema é a água, a oxidação ocorre gradativamente, ao contrário quando o ácido ou o sulfato ferroso amoniacal apresentam alguma impureza (oxidação imediata). Problemas envolvendo o alaranjado Xilenol podem ser devidos às condições de estocagem, uma vez que esse componente é altamente hidrofílico. Essa hidroafinidade pode ocasionar uma sub-pesagem desse componente devido às moléculas de água a ele agregadas ${ }^{2}$

Para a calibração, as amostras devem ser irradiadas na posição horizontal, de modo a evitar influências de possíveis gap's de ar da parte aberta da cubeta. Isso garante que todas as amostras serão irradiadas a partir da parede lateral da cubeta. Ademais, deve-se empregar material água-equivalente a fim de garantir as condições de equilíbrio eletrônico em todas as direções ao redor das amostras ${ }^{3}$. Além disso, a taxa de dose utilizada para a calibração do FXG deve ser igual ou superior à 0,2 Gy/min (devido ao desvanecimento de aproximadamente $1 \% / \mathrm{h}$ ), doses absorvidas de $[\approx 0 ; 50]$ Gy e uma precisão menor do que $5 \%$ para os resultados. Por fim, devese garantir uma maior uniformidade possível para o campo de radiação utilizado de modo que esta seja conhecida e aceitável.

As análises das amostras devem ser prioritariamente realizadas por espectrofotômetro capaz de medir absorbâncias até $3,0 \mathrm{~cm}^{-1}$, com incertezas não maiores do que $1 \%$ na região de $585 \mathrm{~nm}$, sendo os dados calculados de acordo com a Equação (2.1). O balanço de zeros do espectrofotômetro deve ser configurado para quando existir apenas ar no compartimento de amostra. O blank deve ser obtido medindo-se uma cubeta preenchida apenas com água destilada ou, preferencialmente, Milli-Q. Cubetas com caminho óptico de $10 \mathrm{~mm}$ são desejáveis em razão da caracterização

\footnotetext{
${ }^{2}$ Este também foi um dos motivos para propor uma concentração do alaranjado de Xilenol até maior do que a necessária, para obter linearidade em toda a faixa de doses absorvidas.

${ }^{3} \mathrm{~A}$ espessura de cada material, para atender às condições de equilíbrio, dependerá da energia da radiação utilizada.
} 
realizada neste trabalho e da disponibilidade comercial. O comprimento de onda ótimo para as leituras é o comprimento de onda que apresenta o maior pico de absorção, que no caso do dosímetro FXG proposto continua sendo em torno de 585 nm. Além disso, se a absorbância inicial, isto é, a absorbância do dosímetro não irradiado, for superior à $0,15 \mathrm{~cm}^{-1}$, deve-se evitar a utilização dessa receita e preparar outra.

O sistema dosimétrico, composto do dosímetro FXG e do equipamento de análise (espectrofotômetro ou sistema digital $C C D$ ) deve ser regularmente calibrado de modo a garantir que a precisão das medidas de dose absorvidas encontram-se dentro dos intervalos aceitáveis. Isso pode ser realizado medindo-se a taxa de dose em uma instalação que possua uma taxa de dose conhecida e sobretudo rastreável de acordo com os padrões nacionais. Tanto as diferenças observadas, quanto suas respectivas incertezas devem ser incorporadas nas estimativas fornecidas pelo sistema dosimétrico. Assim como os filmes GAFCHROMIC ${ }^{\circledR}$, as cubetas com FXG são passíveis à riscos e contaminações em suas superfícies. Contudo, se um mínimo de cuidado for tomado durante o transporte, manuseio e limpeza, esses efeitos não representam limitações significativos. 


\section{Índice Remissivo}

A

ANOVA, 62, 89

Annealing, 56

B

Blank, 36

C

$C C D, 25,37,41,52,54,56,76,83$, $86,90,95,96,98,147,149$

Cloreto de sódio, 52, 78, 81

Condições Gerais dos Experimentos, $48-53$

$C C D, 59,61$

Coeficiente de Correlação Linear, 49, 62,89

D

Difusão, 22-26, 36

Dose absorvida, 35

DECH-AT, 2, 3, 6-14, 16

Dosímetro, 19

Dosimetria, 17

E

ESF, 39

Erro Padrão de Previsão, 49, 62, 89, S 90

F

FFT, 39

FXG, 4, 20, 22-25, 34, 35, 37, 44, 4850, 64, 65, 67-69, 71, 72, 76, 98, 110

Filme GAFCHROMIC, 28, 37, 39, $55,58,59,84,95,149$
Filme, 20, 27

Fricke, 17, 19, 20, 22, 23, 48-50, 93, 94

$\mathbf{H}$

$H L A, 8,9,14$

I

Intensidade relativa, 37

Incerteza, 61, 64

L

$L S F, 39$

M

MTF, 39

Método Monte Carlo, 31, 32

Mínimos Quadrados, 49, 67

$\mathbf{P}$

PENELOPE, 30-32, 104

Precisão, 49, 64

$\mathbf{R}$

RAD-Sure, 4, 28, 29, 52

Repetitividade, 50, 76, 78

Resolução em Dose Absorvida, 53

RadTag, 4, 28, 29, 52

Sensibilidade, 49

Stopping Power, 94

$\mathbf{T}$

$T L D, 26,27,56$

TL, 4, 55-57, 96, 98

Taxa de dose, 53, 83

t de Student, 62

Termoluminescência, 26 
Teste F, 62 